\author{
UNIVERSIDADE DE SÃO PAULO \\ ESCOLA DE COMUNICAÇÕES E ARTES \\ PROGRAMA DE PÓS-GRADUAÇ̃̃̃O EM CIÊNCIA DA INFORMAÇÃO
}

MARIELLE BARROS DE MORAES

AS TRANSFORMAÇÕES DOS PROCESSOS DE MEDIAÇÃO DA INFORMAÇÃO NOS CURRÍCULOS DE FORMAÇÃO DO BIBLIOTECÁRIO BRASILEIRO NO CONTEXTO DA SOCIEDADE DA INFORMAÇÃO 
MARIELLE BARROS DE MORAES

\section{AS TRANSFORMAÇÕES DOS PROCESSOS DE MEDIAÇÃO DA INFORMAÇÃO NOS CURRÍCULOS DE FORMAÇÃO DO BIBLIOTECÁRIO BRASILEIRO NO CONTEXTO DA SOCIEDADE DA INFORMAÇÃO}

Dissertação de Mestrado apresentada ao Programa de Pós-Graduação em Ciência da Informação, da Escola de Comunicações e Artes da Universidade de São Paulo, para obtenção do título de Mestre em Ciências, sob a orientação do Prof. Dr. Marco Antônio de Almeida. Área de Concentração: Cultura e Informação Linha de Pesquisa: Apropriação Social da Informação 
Dados Internacionais de Catalogação na Publicação (CIP) (Bibliotecária Marielle Barros de Moraes CRB-3/1064)

M827t

Moraes, Marielle Barros de

As transformações dos processos de mediação da informação nos currículos de formação do bibliotecário brasileiro no contexto da Sociedade da Informação / Marielle Barros de Moraes. São Paulo, 2012.

201f. ; $31 \mathrm{~cm}$.

Dissertação (Mestrado) - Universidade de São Paulo, Escola de Comunicações e Artes, Programa de Pós-Graduação em Ciência da Informação, São Paulo, 2012.

Área de Concentração: Cultura e Informação.

Orientação: Prof. Dr. Marco Antônio de Almeida.

1. Biblioteconomia- Estudo e Ensino (Graduação)- Brasil. 2. BiblioteconomiaCurrículo- Brasil. 3. Tecnologias de Informação e de Comunicação. 4. Mediação da Informação. 5. Apropriação Social da Informação. 6. Ciência da Informação. 7. Sociedade da Informação. I. Almeida, Marco Antônio. II. Universidade de São Paulo, Escola de Comunicações e Artes, Programa de Pós-Graduação em Ciência da Informação. III. Título. 


\title{
AS TRANSFORMAÇÕES DOS PROCESSOS DE MEDIAÇÃO DA INFORMAÇÃO NOS CURRÍCULOS DE FORMAÇÃO DO BIBLIOTECÁRIO BRASILEIRO NO CONTEXTO DA SOCIEDADE DA INFORMAÇÃO
}

Dissertação de Mestrado apresentada ao Programa de Pós-Graduação em Ciência da Informação, da Escola de Comunicações e Artes da Universidade de São Paulo, para obtenção do título de Mestre em Ciências, sob a orientação do Prof. Dr. Marco Antônio de Almeida.

Área de Concentração: Cultura e Informação

Linha de Pesquisa: Apropriação Social da Informação

Data de Aprovação:

1

Conceito:

BANCA EXAMINADORA

Prof. Dr. Marco Antônio de Almeida (Orientador)

Doutor em Ciências Sociais

Universidade de São Paulo

Prof. Dr. EImir de Almeida (Membro)

Doutor em Educação

Universidade de São Paulo

\author{
Prof ${ }^{\mathrm{a}}$. Dr ${ }^{\mathrm{a}}$. Giulia Crippa (Membro) \\ Doutora em História Social \\ Universidade de São Paulo
}


Aos meus pais e irmãs responsáveis pela minha formação primeira, principalmente, à Mirlânia de Moraes, mais que irmã, uma amiga. A alguns professores que me são exemplos de intelectuais no sentido gramsciano do termo: Dr. Marco Antônio de Almeida, Dr. Casemiro Silva Neto, Dr ${ }^{\mathbf{a}}$. Virginia Bentes Pinto, Dra . Giulia Crippa, Dra Ivete Pieruccini e Dra ${ }^{\mathbf{a}}$. Marilda Lara. A Flávio Lima, companheiro e grande incentivador nestes últimos anos. Aos meus amores... 


\section{AGRADECIMENTOS}

Durante a nossa trajetória acadêmica contamos com a participação, apoio e generosidade de alguns atores do nosso palco vidal que muito contribuíram para que chegássemos até esta estação, que ainda não é a última, mas que, com certeza, já é a segunda exitosa. Portanto, mesmo que não tenhamos desembarcado em algumas estações importantes para nós, devido ao fato de alguns condutores não nos terem quisto deixar embarcar, não nos deixamos permanecer na estação que alguns queriam que fosse a final e avançamos para outras. É como diz o grande poeta Fernando Pessoa: Pedras no caminho? Guardo todas. Um dia construirei um castelo! Mesmo assim, inicio agradecendo a esses condutores, pois os seus “não quereres" nos fizeram ir mais além do que a estação anterior.

Em primeiro lugar, agradeço a Deus a oportunidade que me foi dada de ter sido aluna do Mestrado em Ciência da Informação da USP. Sei que sem a fé que Nele tenho, o percurso e as pedras teriam sido muito maiores e mais pesadas. Agradeço à minha família, cujos nomes não poderei citar todos, mas que são pessoas que também tornaram o meu sonho possível, em especial meu pai, minha mãe e minhas irmãs, aos quais busco sempre dar o meu melhor exemplo de ser humano e profissional. Como não poderia deixar de ser, agradeço à Prof $^{a}$. Dra . Virginia Bentes Pinto- Universidade Federal do Ceará (UFC), a qual sempre me incentivou a fazer o mestrado. Depois de algumas estações nebulosas, ainda ecoam em meus labirintos neurais suas palavras "daqui é pra frente, não é mesmo?" Com a sua sabedoria, plantou e também tornou possível a concretização do mestrado. Outro ator desse palco foi o Prof. Dr. Casemiro Silva Neto da UFC a quem dedico um profundo carinho e respeito por todos os momentos compartilhados e por todas as vezes que atendeu meus telefonemas quando precisei conversar com alguém. Não poderia esquecer também da bibliotecária Rosane Mota da UFC, pelas gentis colaborações em todos os momentos que solicitei.

Um agradecimento especial aos meus alunos do Curso de Homeopatia da UFC (Roberto Acioly, Eristow Nogueira, Ângela Oliveira, Ândua Magalhães, Louzane Pedreira, Fátima Magalhães, Socorro Cortez, Gianni Mastroianni, Marta Milyan, Denise Maia, Prof. Msc. Francisco José do Lago Costa- ninguém é profeta em sua própria terra, não é mesmo?-, Cleíse Lago Costa, Prof ${ }^{a}$. Dra . Vera Lúcia Maia Mendonça, Homero Arruda, Jorge Braga, Célia Nogueira, Maiton Lopes, Eudina Costa, Valdenir Moura), em especial, aos professores Dr. Tarcízio Diniz, Msc. Edson Pereira e Dr. Marcus Fernandes de Oliveira pela confiança e respeito a mim dedicados durante os três anos de trabalhos que realizamos juntos. Deus vai trilhando nossa trajetória e inserindo em nosso caminho pessoas especiais, como o Prof. Dr. 
Marcus Fernandes de Oliveira a quem Deus colocou em meu caminho no primeiro dia de vida, de forma inesperada, e que nos possibilitou uma amizade e parceria muito importante na universidade.

Outros professores e amigos a quem não poderia deixar de citar que foram importantes em minha formação em nível de mestrado: Prof. Dr. Marco Antônio de Almeida, Prof $^{\mathbf{a}}$. Dra ${ }^{\mathbf{a}}$. Giulia Crippa, Prof ${ }^{\mathrm{a}}$. Dr ${ }^{\mathbf{a}}$. Marilda Lara, Prof ${ }^{\mathbf{a}}$. Dr ${ }^{\mathbf{a}}$. Lúcia Maciel, Prof ${ }^{\mathbf{a}}$. Dr ${ }^{\mathbf{a}}$. Fátima Tálamo e Prof ${ }^{\mathbf{a}}$. Dr ${ }^{\mathbf{a}}$. Asa Fujino, a quem dedico um agradecimento especial pela força dedicada nos primeiros meses do curso, junto com o Prof. Marcelo dos Santos. André Britto (Aluno do Mestrado Profissional em Propriedade Intelectual e Inovação do INPI) pela abertura das portas de sua casa para que eu pudesse participar do Congresso Brasileiro de Arquivologia. Prof ${ }^{\mathbf{a}}$. Dr ${ }^{\mathrm{a}}$. Rosaline Mota (UFAL) pela abertura das portas de sua casa para que eu pudesse participar do CBBD/2011 e Prof ${ }^{a}$. Msc. Débora Sampaio (UFC-Cariri) por ter feito o mesmo para o evento de História da Educação do Ceará/2011; além do Prof. Msc. Ariel Sánchez Espinoza, professor da Universidade Autônoma do Estado do México, pela amizade e parcerias firmadas durante os três últimos anos e pelos trabalhos que apresentamos no México e em Cuba. Prof ${ }^{\mathbf{a}}$. Dr ${ }^{\mathbf{a}}$. Ivete Pieruccini pelos ensinamentos, parcerias e amizade ao longo destes dois anos. Também gostaria de registrar aqui Prof. Dr. Miguel Ángel Rendón Rojas (UNAM) e Érika Calvo por suas mediações e atenções.

Prof. Dr. Oswaldo Almeida Júnior (UNESP), Prof ${ }^{\mathbf{a}}$. Dr ${ }^{\mathbf{a}}$. Marta Valentim (UNESP), Prof ${ }^{\mathbf{a}}$. Dr ${ }^{\mathbf{a}}$. Valéria Aparecida Bari (UESPI) pelas conversas que me fizeram pensar e repensar algumas ideias do trabalho. Prof. Dr. Marcílio de Brito (UNB), Prof. Dr. Hamilton Vieira Oliveira (UFPA), Prof. Dr. Francisco das Chagas Souza (UFSC), Prof. Dr. Augusto Milanesi (USP) e Pró-Reitoria de Graduação da UFC pela atenção dedicada quando da solicitação do material empírico da pesquisa. Um agradecimento especial a Felipe Salles Silva pela mediação para conseguir o material empírico da USP, com o professor Augusto Milanesi. Também agradeço as valiosas sugestões do Prof. Dr. Elmir de Almeida (USP) e Prof ${ }^{a}$. Dr ${ }^{a}$. Giulia Crippa desde o exame de qualificação.

Um agradecimento a CAPES pela bolsa durante os dois anos do mestrado, sem a qual teria sido muito mais difícil minha estada em São Paulo. À Pró-Reitoria de PósGraduação pelo financiamento da viagem a Cuba para divulgação desta pesquisa em fevereiro deste ano.

Aos colegas do curso de mestrado: Lani Lucas, Joana Braga, Gisele Aguiar, Charlene Lemos, Ana Biscalchin, pelos vários momentos compartilhados. Ao bibliotecário Thiago Gaudêncio Siebert Freire pela abertura das portas de sua casa durante os períodos de 
provas e o início do Curso de Mestrado sem nem mesmo me conhecer; na realidade, me foi como um verdadeiro irmão (a ele, meu muito obrigada). Aos amigos de Residência Universitária: Sarah Damasceno, João Robson, Roberta Raggi, Carlos Noriega, Washington Rodrigues, Humberto Ruggeri, Marilu Palomino. A Júlio Orestes, doutorando da FEA/USP, por tudo. A Flávio Lima pelo companheirismo destes últimos quatro anos, pela confiança e pelo amor a mim dedicados, o qual foi recíproco (pena que tomamos rumos diferentes na vida). Aos alunos PAE por toda a confiança, respeito e reciprocidades durante o semestre que passamos juntos. Agradeço a amiga bibliotecária Ana Wanessa Bastos pela colaboração na apresentação do trabalho do Encontro de Historiadores da Educação do Ceará em 2012. Um agradecimento especial à minha família daqui (Idaci, Anselmo, Dácio e Ricássia) (Jacira e Amilton) e de Fortaleza, cujos nomes não poderei citar todos, mas que sempre me apoiaram em meus projetos de vida.

Prof. Dr. Marco Antônio de Almeida uma parceria que deu certo no conjunto das orientações. Agradeço todos os momentos em que, realmente, precisei ser freada em algumas ideias, mas, talvez, seja assim que se forma um pesquisador. Com toda a sua experiência soube orientar, esclarecer, duvidar, apoiar, educar no sentido freiriano do termo. Apoiou-me nessa dissertação de forma científica, criteriosa e crítica, dando-me tempo para a consecução do trabalho. Sempre que precisei tive seu apoio, principalmente, para guiar minhas inseguranças durante o processo (as quais não foram poucas). Soube escutar, criticar, elaborar, transformar as "pistas de corrida" desta dissertação. Meus mais sinceros agradecimentos por tudo. Se aos seus olhos atentos escaparam alguns erros, assumo a total responsabilidade. Como diz o escritor uruguaio Juan Carlos Onetti, em seu Tão triste como ela: "o mau não é que a vida nos promete coisas que não nos dará nunca; o mau é que sempre as dá, e deixa de dá-las". Portanto, ela me deixou de dar, mas também me deu...

Finalizo, portanto, com uma frase de Riobaldo, no Grande Sertão Veredas: "Viver é muito perigoso [...] e o risco não está na partida ou na chegada. O mais arriscado é a travessia". Espero ter conseguido realizar minha travessia curricular e "vidal". 
"A minha fé, indiscutivelmente, interfere na minha forma de pensar o mundo. [...]. Portanto, não foram os camponeses que disseram a mim: 'Paulo tu já leste Marx?'. Não, eles não liam nem jornal! Foi a realidade deles, que me remeteu a Marx. Quanto mais eu li Marx, tanto mais eu encontrei uma certa fundamentação objetiva para continuar camarada de Cristo. Então, as leituras que fiz de Marx, e alongamentos de Marx, não me sugeriram jamais que eu deixasse de encontrar o Cristo na esquina das próprias favelas. Eu fiquei com Marx na mundanidade, à procura de Cristo na transcendentalidade".

(Paulo Freire, 1997). 


\section{RESUMO}

A sociedade contemporânea está permeada pelas Tecnologias de Informação e de Comunicação, as quais vêm ocasionando diversas transformações nas conceituações societais e nas práticas de mediação informativo-cultural; fato este que deságua nos currículos de formação de bibliotecários no Brasil. Esta nova sociedade, cujas delimitações conceituais e espaços-temporais não são muito precisas, constitui o contexto de surgimento de uma nova ciência, a Ciência da Informação, a qual também é demarcada pela não-delimitação de objeto, metodologias e abrangências, o que influencia na formação de seus profissionais. Neste sentido, analisar como está delineada a formação do bibliotecário brasileiro diante deste contexto torna-se urgente, haja vista estarem as Escolas de Biblioteconomia e Ciência da Informação revendo seus projetos pedagógicos e planos de ensino desde a entrada do século XXI. No contexto desta pesquisa, investigamos como a contemporaneidade influencia as Diretrizes Curriculares Nacionais (DCNs) do Ministério da Educação brasileiro (MEC), as indicativas da Associação Brasileira de Educação em Ciência da Informação (ABECIN) e os currículos formativos em cinco universidades brasileiras para perceber como as Tecnologias de Informação e de Comunicação alteraram os conteúdos curriculares e como as questões mediacionais estão inseridas nos mesmos. Para tanto, apoiamo-nos na Pesquisa Teórica Exploratória, no Método Comparativo e na Análise de Conteúdo. As análises demonstraram defasagens de diversos níveis dos currículos em relação ao documento da $\mathrm{ABECIN}$, bem como a utilização das terminologias das competências; além disso, demonstra que a visão de mediação inserida nesses currículos ainda é de uma mediação tradicional- embora alguns tratem da relação dessa mediação com as Tecnologias de Informação e de Comunicação.

Palavras-chave: Formação do Bibliotecário. Mediação da Informação. Currículo. Tecnologias de Informação e de Comunicação. Sociedade da Informação. 


\begin{abstract}
The contemporary society is permeated by the Information Technology and Communication, which are causing many changes in societal concepts and practices of information-cultural mediation, fact which empties into the curricula of training librarians in Brazil. This new company, whose conceptual boundaries and space-time are not very accurate, is the context of the emergence of a new science, information science, which is also marked by non-boundary object, methodologies and coverage, which influences the training of its professionals. In this sense, as is outlined analyze the formation of the Brazilian librarian within this context becomes urgent, considering they are the Schools of Library and Information Science reviewing its educational projects and lesson plans from the entrance of the XXI century. In the context of this study, we investigated how the contemporary influences the National Curriculum Guidelines (DCNs) of the Brazilian Ministry of Education (MEC), indicative of the Brazilian Association for Education in Information Science (ABECIN) curricula and training in five Brazilian universities to realize As the Information and Communication changed the curriculum and how the issues are incorporated in the same mediational. For this, we rely on the Theoretical Exploratory Research in Method Comparative and Content Analysis. The analyzes showed gaps at various levels of the curriculum in relation to the document ABECIN, and the use of terminology skills and additionally demonstrates that the vision of mediation inserted in these curricula is still a traditional mediation, although some deal with the relation of this mediation with the Information Technology and Communication.
\end{abstract}

Keywords: Teaching Library. Curriculum. Mediation of Information. Information Technology and Communication. 


\section{LISTA DE QUADROS}

Quadro 1- Marcos da Teoria Crítica de Currículo.

Quadro 2- Demonstração dos fluxos de informações da interação face a face (à esquerda), da interação mediada (ao meio) e da quase-interação mediada (à direita). .87

Quadro 3- Características dos tipos de interação comunicacionais............................................ 90

Quadro 4- Modelo de Comunicação de Shannon e Weaver....................................................... 103

Quadro 5- Lista dos documentos elaborados pela ABECIN ..................................................... 118

Quadro 6- Comparação das áreas curriculares da ABECIN e da UFPA .................................... 138

Quadro 7- Comparação das áreas curriculares ABECIN e UFSC............................................. 147

Quadro 8- Áreas e disciplinas do Curso de Biblioteconomia da UNB ...................................... 155

Quadro 9- Comparação das áreas curriculares ABECIN e UNB ............................................. 156

Quadro 10- Comparação das áreas curriculares ABECIN e USP ............................................. 166

Quadro 11- Comparação das áreas curriculares ABECIN e UFC .............................................. 176

Quadro 12- Comparação das áreas curriculares da ABECIN, UFPA, UFSC, UNB, USP e

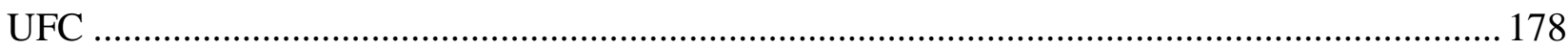




\section{LISTA DE ABREVIATURAS E SIGLAS}

ABEBD Associação Brasileira de Ensino em Biblioteconomia e Documentação ABECIN Associação Brasileira de Educação em Ciência da Informação

BM Banco Mundial

CAC Coordenadoria de Avaliação e Currículo

CENIS Center for International Studies

CEPE Conselho de Ensino, Pesquisa e Extensão

CFB Conselho Federal de Biblioteconomia

CI Ciência da Informação

CIA Central Intelligence Agency

CID Departamento de Ciência da Informação e da Documentação

CNE/CSE Conselho Nacional de Educação/Câmara de Educação Superior

CTA Central de Tele Atendimento

G7 Grupo dos Sete

CONSUNI Conselho Universitário

DAA Diretoria de Administração Acadêmica

DARPA Defense Advanced Research Projects Agency

DCI Departamento de Ciências da Informação

DCN Diretrizes Curriculares Nacionais

DSI Disseminação Seletiva da Informação

ECA Escola de Comunicações e Artes

ECC Escola de Comunicações Culturais

ENIAC Electrical Numerical Integrator and Computer

FMI Fundo Monetário Internacional

FUBICA Faculdade de Biblioteconomia e Informação Científica

IBBD Instituto Brasileiro de Bibliografia e Documentação

IBM International Business Machines

ICA Instituto de Cultura e Arte

INPI Instituto Nacional de Propriedade Intelectual e Inovação

ISEB Instituto Superior de Estudos Brasileiros

LDB Leis de Diretrizes e Bases da Educação Nacional

MAUC Museu de Arte da Universidade Federal do Ceará

MEC Ministério da Educação 
MEMEX Memory Extension

MERCOSUL Mercado Comum do Sul

MIT Massachussets Institute of Technology

ONGs Organizações Não Governamentais

ONU Organizações das Nações Unidas

PB Paraíba

PPGCI Programa de Pós-Graduação em Ciência da Informação

PPP Projeto Político Pedagógico

PR Paraná

SDI Strategic Defense Iniciative

SESU Secretaria de Educação Superior

SI Sociedade da Informação

TCC Trabalho de Conclusão de Curso

TICs Tecnologias de Informação e de Comunicação

UESPI Universidade Estadual do Piauí

UFAL Universidade Federal de Alagoas

UFBA Universidade Federal da Bahia

UFC Universidade Federal do Ceará

UFG Universidade Federal de Goiás

UFMG Universidade Federal de Minas Gerais

UFPA Universidade Federal do Pará

UFS Universidade Federal de Sergipe

UFSC Universidade Federal de Santa Catarina

UNAM Universidad Nacional Autónoma de México

UNB Universidade de Brasília

UNESP Universidade Estadual Paulista

UNIRIO Universidade Federal do Estado do Rio de Janeiro

USP Universidade de São Paulo 


\section{SUMÁRIO}

1 INTRODUÇÃ̃ ......................................................................................................................... 16

2 SOCIEDADE DA INFORMAÇÃO: DA MODERNIDADE AO CONTEMPORÂNEO. 24

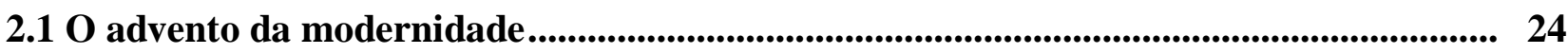

2.2 Pós-Modernidade: ruptura ou continuidade? ............................................................... 30

2.3 Sociedade da Informação, Economia e Neoliberalismo ................................................... 40

3 A FORMAÇÃo EM CIÊNCIA DA INFORMAÇÃo E A QUESTÃo DA MEDIAÇÃ

3.1 Teorias do Currículo .............................................................................................................. 57

3.1.1 Impactos do neoliberalismo sobre os currículos..................................................... 70

3.2 Ciência da Informação e Biblioteconomia......................................................................................... 73

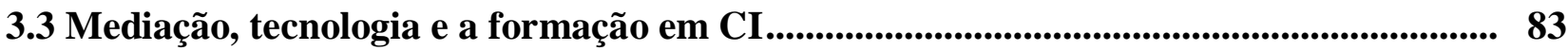

4 TRILHAS INVESTIGATIVAS: O CONTIDO E O NÃO CONTIDO NOS CURRÍCULOS ................................................................................................................................................ 106

4.1 Caminho analítico do documento do MEC .............................................................................. 111

4.2 Caminho analítico dos documentos da ABECIN ................................................................ 118

4.3 Caminho analítico do currículo do Curso de Biblioteconomia da UFPA ....................... 131

4.4 Caminho analítico do currículo do Curso de Biblioteconomia da UFSC .......................... 139

4.5 Caminho analítico do currículo do Curso de Biblioteconomia da UNB........................... 150

4.6 Caminho analítico do currículo do Curso de Biblioteconomia da USP............................ 157

4.7 Caminho analítico do currículo do Curso de Biblioteconomia da UFC ............................ 169

4.8 Algumas considerações sobre os currículos numa perspectiva comparada..................... 176

5 REFLEXÕES FINAIS: DIALÉTICAS CURRICULARES ................................................ 184

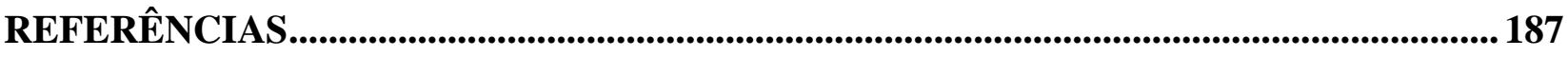




\section{INTRODUÇÃO}

Todas as coisas são ajudadas e ajudantes, todas as coisas são mediatas e imediatas, e todas estão ligadas entre si por um laço que conecta umas às outras, inclusive as mais distanciadas.

Pascal

Acontecimentos históricos e revoluções sempre tiveram influência na construção das sociedades e nos rumos da trajetória humana. A Revolução Industrial, em suas três versões, trouxe inovações em todos os setores da vida humana e social. A primeira adotava o carvão como fonte de energia, a máquina a vapor e a locomotiva, utilizando a força mecânica em detrimento da força física. A segunda teve início na segunda metade do século XIX, através da eletricidade, do transporte ferroviário, do telégrafo e do motor a combustão. A terceira é nossa contemporânea, mobilizou microchips, que transformaram as formas de comunicação e de informação, com a explosão da Internet e do comércio eletrônico. Ou seja, as duas primeiras desvalorizaram, respectivamente, o trabalho muscular e o trabalho mental de rotina, enquanto que a terceira trata da substituição das máquinas grandes e pesadas do industrialismo, pela miniaturização e leveza das novas Tecnologias de Informação e de Comunicação (TICs). Há, ainda, quem fale que estamos numa quarta revolução industrial devido à crescente utilização da nanotecnologia, que mobiliza as ciências da vida, sob a forma da biotecnologia, bem como uma gama de ciências exatas e cognitivas que responde ao nome de nanociência. Ou seja, parece que está se concretizando o desejo dos cientistas de domar o infinitamente pequeno (moléculas, partículas, átomos) que compõe e faz funcionar o infinitamente grande, ou seja, o universo (ALMEIDA, P., 2005).

Essas transformações alteraram os rumos das profissões em geral e, com a Biblioteconomia, não foi diferente. Mesmo sabendo que estamos no limiar de uma quarta revolução industrial, nosso objeto de maior interesse encontra-se na terceira versão, pois foi ela que propiciou a emergência do modelo de globalização econômica em curso, bem como a reconfiguração dos sistemas social, político, cultural e cognitivo. Exemplos dessa reconfiguração, trazidas pela Revolução Industrial, são as mais variadas formas como as Tecnologias de Informação e de Comunicação vêm contribuindo para a mediação e aproximação dos povos e das culturas, o que modifica toda uma configuração anterior dos sistemas sociopolítico cultural e cognitivo.

Outro exemplo do progresso advindo com a Revolução Industrial é quando ouvimos falar que "o mundo está cada dia mais acelerado." As distâncias percorridas, tanto para o transporte de materiais concretos, reais, quanto para levar ao outro lado do mundo 
informações, dados virtuais, digitais, ganharam novos veículos, graças às tecnologias disponíveis em cada tempo. Assim, a revolução tecnológica, ou o progresso, como diz Harvey (2003, p. 190) trouxe "a conquista do espaço, a derrubada de todas as barreiras espaciais e a aniquilação do espaço através do tempo".

As transformações espaços-temporais, advindas com a Terceira Revolução Industrial, acarretaram a representação de um ideal capitalista vigente: uma produção acelerada, que rende uma economia de tempo e, portanto, rende mais lucro. A partir de então, a aceleração revolucionou a estrutura temporal mediante o que Castells (1999) denomina de os "sistemas de fluxos". A movimentação desses fluxos mostra-se eficiente quando as empresas trabalham em rede, conectadas umas às outras, seja na troca de mão de obra, matéria-prima, informações ou produtos já comercializáveis. Harvey (2003, p. 148) adiciona a Castells (1999) a questão da instabilidade gerada por esses sistemas de fluxos, pois, segundo ele, "a estética relativamente estável do modernismo fordista cedeu lugar a todo o fermento, instabilidade e qualidades fugidias de uma estética pós-moderna que celebra a diferença, a efemeridade, o espetáculo, a moda e a mercantilização de formas culturais".

Estamos, portanto, numa sociedade que opera em rede, que conecta os mais diversos povos e nações independentemente do espaço e do tempo e, tal fato, além de quebrar fronteiras, garante o acesso às informações e às trocas culturais. No entanto, é necessário verificar, também, que um novo usuário nasce diante da mídia digital/online. A tão estudada "passividade" frente aos fluxos informativos toma nova forma, questionando novamente o posicionamento do emissor-receptor na estrutura do sistema comunicacional. A partir dessa perspectiva, o chamado usuário (em outras palavras, aquele que se vale e que usa a informação) tem a opção de interagir. Possibilidades de armazenamento de dados (informação enquanto um bem próprio do receptor), de feedback, de escolhas não lineares, de publicações sem filtros (como em blogs), mostram-se como potencialidades não de um usuário passivo, mas interativo em uma ambiência digital/online. Essa observação já foi verificada por Harvey (2003, p. 259) como uma das condições da pós-modernidade: a capacidade de optar e obter a informação disponibilizada em banco de dados, em qualquer tempo e lugar. O rompimento dessa linearidade obrigatória garante liberdade de escolha de conteúdos ao receptor, o qual, nesse momento, torna-se proprietário da informação. O receptor, dessa forma, é um interagente no fluxo informativo, agindo como um verdadeiro editor de montagem de seu próprio tempo e espaço de fluxo.

Nesse contexto, vai se construindo um novo senso comum em relação à ideia de mediação: a ação de servir de intermediário ou de ser o que serve de intermediário. Assim, 
“cristaliza-se aqui a concepção de que essa ação não é o estabelecimento de uma simples relação entre dois termos de mesmo nível, mas que, em si, ela é produtora de um 'algo a mais’, de um estado mais satisfatório" (ALMEIDA, M., 2008, p. 3). Segundo o autor, essa perspectiva se generalizou, atribuindo-se esse papel ao "profissional da informação" (seja ele denominado bibliotecário, arquivista, museólogo ou outra definição profissional). Por outro lado,

\begin{abstract}
A ideia de mediação acaba por cobrir coisas tão diferentes entre si, que vão das velhas concepções de "atendimento ao usuário" à atividade de um agente cultural em uma dada instituição - museu, biblioteca, arquivo, centro cultural-, à construção de produtos destinados a introduzir o público num determinado universo de informações e vivências (arte, educação, ecologia, por exemplo), à elaboração de políticas de capacitação ou de acesso às tecnologias de informação e de comunicação, etc. Desse modo, uma definição consensual de mediação parece impraticável: sempre contextualizada, torna-se um conceito plástico que estende suas fronteiras para dar conta de realidades muito diferentes entre si (ALMEIDA, M., 2008, p. 3).
\end{abstract}

A partir do contexto socioeconômico e das mudanças introduzidas pelas novas tecnologias, os mais diversos campos profissionais foram reconfigurados como forma de atender a esse novo tipo de sociedade que vem emergindo desde o pós-Segunda Guerra Mundial. Essas reconfigurações sociopolíticas e econômicas vieram a desaguar no âmbito escolar e, diante deste contexto, os currículos dos mais diversos níveis de ensino tiveram de se adaptar às novas exigências do mercado, principalmente, no que concerne ao trabalho com os fluxos de informação. Ou seja, devido a essa demanda socioeconômica, os currículos tiveram de se adaptar aos anseios do mercado que trabalha em rede, com fluxos de informações, em decorrência das Tecnologias de Informação e de Comunicação. Em relação ao nível superior de ensino, essas mudanças curriculares dão-se a fim de que os cursos não se tornem obsoletos diante das mudanças de paradigmas referentes ao excesso de informação e a consequente dificuldade de conquista do acesso. Nesse cenário, a formação universitária, de qualquer área profissional (com reflexos inclusive no ensino fundamental, médio e profissionalizante), estrutura-se no cumprimento fiel de seu currículo, como modelo a ser seguido. Este aparelho ideológico, o currículo, dispõe sobre a obrigatoriedade do cumprimento das disciplinas e o norteamento do perfil profissional que se quer colocar no mercado, mesmo levando-se em conta as flexibilizações sugeridas pela Lei de Diretrizes e Bases da Educação Nacional (LDB), principalmente, em relação à necessidade de atualizações.

No caso da Biblioteconomia e da Ciência da Informação (CI), independentemente de se falar de graduação ou de pós-graduação, não poderia ser diferente. Sob a égide da 
discussão de uma "Sociedade da Informação" e de seus desdobramentos, reconfigura-se uma nova figura de bibliotecário entendido como profissional da informação, para o qual as atividades de mediação da informação desempenhariam papel estratégico, mas que ainda não estão claramente delineadas. Ou seja, as descobertas e os avanços da Sociedade da Informação não param e, nesse ínterim, perguntamo-nos: como ficam as formações profissionais diante desse contexto delineado até o presente momento? E, especificamente, como está sendo delineada a formação do bibliotecário brasileiro diante deste contexto? Qual a relação desse contexto contemporâneo de pós-modernidade e sociedade informacional com aquilo que se denomina de neoliberalismo? Como esse contexto contemporâneo influenciou as Diretrizes Curriculares Nacionais e os currículos formativos, em especial, o da Biblioteconomia a partir da Lei 9.131, de 25 de novembro de 1995, o Parecer do Conselho Nacional de Educação da Câmara de Educação SuperiorCNE/CES 492, de 3 de abril de 2001, homologado em 9 de julho de 2001, e o Parecer CNE/CES 1363/2001? É, pois, no território destas e de outras questões, complexas e desafiadoras, que esta dissertação se inscreve, buscando, através da pesquisa proposta, trazer subsídios para uma melhor compreensão desse processo no contexto das universidades públicas brasileiras.

O objeto sobre o qual esta pesquisa debruçou-se foi o currículo dos cursos de Biblioteconomia no Brasil. A partir das reflexões enunciadas na introdução deste projeto, formulamos as seguintes questões-problema: qual é a influência da emergência de uma "Sociedade da Informação" baseada em redes de comunicação e de informação, nos currículos dos Cursos de Biblioteconomia no Brasil, especificamente na Universidade Federal do Ceará (UFC)- Capital, Universidade de São Paulo (USP)- Capital, Universidade Federal do Pará (UFPA), Universidade Federal de Santa Catarina (UFSC) e Universidade de Brasília (UNB)? Como o desenvolvimento das Tecnologias de Informação e de Comunicação (TICs), a partir de meados da década de 1990, alterou os conteúdos relativos à formação do bibliotecário brasileiro, também denominado de profissional da informação? Como, especificamente, os currículos desses cursos tratam a questão da mediação da informação e sua importância na formação de um perfil profissional nesse novo contexto?

Em primeiro lugar, a amostra selecionada para a análise foi de um currículo por região, para tentar ter uma visão mais global do caso brasileiro na amostragem. No Brasil, existem aproximadamente 63 cursos de Biblioteconomia, incluindo os cursos com a denominação de Gestão, Ciência da Informação e Licenciatura em Biblioteconomia. Por questões óbvias de tempo, fôlego e dimensionamento desta dissertação, no entanto, a 
amostragem inclui apenas um curso por região brasileira. O curso da Região Norte, que se encontra na UFPA, foi escolhido por ser um dos mais antigos dessa região (1963); portanto, pode-se considerar um curso com tradição de ensino na área de Biblioteconomia. O curso da Região Nordeste foi escolhido, não em vista da sua tradição, pois no caso dessa região, o curso mais antigo é o da Universidade Federal da Bahia (UFBA), o qual foi criado em 1942. A escolha do curso da UFC-Fortaleza deu-se porque já havíamos realizado um estudo sobre o novo fluxo curricular da UFC e pretendíamos ampliar esses estudos em nível de mestrado, tendo em vistas não começar esses estudos outra vez, mas avançar a partir de onde já tínhamos parado. Por isso, preferimos escolher a UFC, além de termos tido acesso ao material empírico da pesquisa. No caso da Região Centro-Oeste escolhemos o Curso de Biblioteconomia da UNB por ter sido um dos primeiros cursos a ser criado na região CentroOeste. Já na Região Sul, escolhemos a UFSC pelo acesso ao material empírico e porque é uma escola onde se desenvolvem estudos acerca da formação de bibliotecários o que é uma boa referência a se analisar nos currículos. Por fim, escolhemos na Região Sudeste o curso de Biblioteconomia da USP-capital, cuja criação se deu em 1966, e já tem tradição na formação de bibliotecários no estado de São Paulo.

Em nossas primeiras buscas acerca da temática da formação profissional em Biblioteconomia encontramos alguns autores que já abordaram o tema da análise dos cursos de graduação em Biblioteconomia e da formação dos profissionais da área em nível nacional, como Castro (2000); Souza, F. (2001, 2002, 2009, 2006); Milanesi (2002); Valentim (2002); Fujino e Lima (2008). Todavia, em nossos percursos pela bibliografia acerca da temática não encontramos trabalhos que se debruçassem sobre a análise dos currículos (Projetos Pedagógicos e Programa de Disciplinas) em nível nacional. O trabalho mais atual que encontramos que se aproxima das análises que fazemos neste empreendimento acadêmico é um artigo de Souza, F. (2002) intitulado Educação bibliotecária, pesquisa em educação bibliotecária e as novas DCN (Diretrizes Curriculares Nacionais) do Curso de Biblioteconomia no Brasil, além do livro de Cysne (1993) e do artigo de Costa, Carvalho e Andrade (1999) sobre a análise do currículo da UFC, mas até a década de 1990. Por outro lado, ao debruçar-se sobre o papel atribuído às atividades de mediação da informação nesses currículos (ou a sua ausência), a pesquisa poderá colaborar com as reflexões que procuram pensar, criticamente, os caminhos trilhados pelas profissões, em geral, e, em particular, a do profissional da informação/bibliotecário. A novidade que a ele poderá ser creditada decorre, portanto, do fato de haver escolhido, como foco de estudo, os currículos implementados a partir da última reformulação curricular no País, sugerida pela LDB, tomando como pano de 
fundo o contexto brasileiro recente, com a forte presença de ideias de caráter neoliberal e de processos de reorganização do Estado. Além disso, para tecer uma análise crítica nos currículos de Biblioteconomia brasileiros, apoiamo-nos nas ideias de Freire (1967, 1978, 1979, 1981, 1983, 1997, 2000, 2005).

Este estudo aponta para a importância da compreensão da contextualização histórica, social, política, econômica e epistemológica envolvida na formação do bibliotecário. Para isso, faz-se necessária uma reflexão teórica acerca da área de Ciência da Informação, uma vez que a referida área é uma Ciência Social Aplicada com características interdisciplinares que dialoga com diversos campos científicos. A questão da interdisciplinaridade não apresenta uma perspectiva unânime, entretanto, e tem sido alvo de muitas discussões na área em autores como Saracevic (1996); Le Coadic (1996); Smit (2000); González de Gómez e Orrico (2006); Capurro e Hjørland (2007); Tálamo e Smit (2007); Smit; Tálamo e Kobashi (2004); Bentes Pinto (2007); Mueller (2007); Souza (2007), dentre outros. No que tange, especificamente, ao seu papel na constituição dos cursos de graduação e na formação dos profissionais, recebeu a atenção de uma série de seminários e discussões patrocinadas pela ABECIN (Associação Brasileira de Educação em Ciência da Informação), transformados em documentos que, pela sua importância para o foco do trabalho, também serão contemplados pela pesquisa.

Este estudo insere-se na linha de pesquisa Apropriação Social da Informação, no tema da mediação da informação no currículo de formação do bibliotecário brasileiro e foi desenvolvido no Programa de Pós-Graduação em Ciência da Informação da Universidade de São Paulo. Envolve a formação do bibliotecário brasileiro no contexto contemporâneo, tomando por base a historicidade da formação desse profissional e da própria Biblioteconomia no Brasil, enfatizando o papel da mediação da informação na reconfiguração dos currículos. Para visualizar a mediação no interior do currículo, pautamo-nos nas ideias de mediação de Lamizet e Silem (1967); Floris (1995); Jouët (1993); Miège (2009); Caune (2000); Davallon (2007); Almeida, M. (2008); Almeida Júnior (2009). Busca, efetivamente, visualizar a mediação da informação no âmbito do conteúdo textual do currículo e de que forma essa mediação poderá contribuir para uma apropriação da informação por parte dos alunos dos Cursos de Biblioteconomia, com vistas a que eles saibam utilizar os conteúdos curriculares como forma de perceber e transformar a realidade ao seu redor.

O objetivo geral da pesquisa proposta é analisar a influência do contexto socioeconômico e tecnológico da Sociedade da Informação nos currículos dos Cursos de Biblioteconomia no Brasil, especificamente, na UFC- Fortaleza, USP- Capital, UFPA, UFSC 
e UNB, a partir da década de 1990, levando em consideração os aspectos referentes à mediação da informação no conteúdo do texto curricular. Desse modo, buscar-se-á, de forma específica: a) Investigar a influência das Tecnologias de Informação e de Comunicação, a partir da década de 1990, na alteração do conteúdo informacional explícito dos currículos, a partir do texto de seus projetos político-pedagógicos, de formação do bibliotecário brasileiro; b) estudar a influência das Tecnologias de Informação e de Comunicação sobre a composição textual do conteúdo da informação curricular dos Cursos de Biblioteconomia da UFC, USP, UFPA, UFSC e UNB, a partir da última reforma curricular; c) inferir o papel desempenhadoou que poderia ser desempenhado- pela mediação da informação na estruturação e no conteúdo do currículo do Curso de Biblioteconomia das universidades em questão.

Os objetivos teóricos e práticos da pesquisa são: a) aprofundar e sistematizar o conhecimento sobre os estudos curriculares, contribuindo, dessa forma, para a discussão acerca da epistemologia da Biblioteconomia e da Ciência da Informação; b) compreender a problemática da mediação da informação e sua relação com a formação dos profissionais da área de Biblioteconomia por meio de sua expressão nos currículos universitários; c) obter elementos para analisar os desdobramentos e a capacidade de aplicação prática dos conteúdos relativos ao currículo, considerando as possibilidades de melhorias no processo de construção curricular, numa visão mais crítica dos contextos sociais em que os profissionais formados atuarão.

Os caminhos desta dissertação foram trilhados em três partes, além desta introdução e da conclusão. A primeira denominada de Sociedade da Informação: da modernidade ao contemporâneo, analisa as mais variadas formas de se conceituar e caracterizar o período contemporâneo, pautando-nos, principalmente, nos conceitos de modernidade, pós-modernidade, Sociedade da Informação, neoliberalismo. A segunda parte refere-se aos percursos metodológicos por nós escolhidos, apresentando as formas de encaminhamento teórico e de análises de dados e tratamento do material empírico, e de como os conceitos discutidos, anteriormente, bem como suas características, deságuam nos currículos acadêmicos, principalmente, na Ciência da Informação e nos seus processos de mediação da informação. A terceira parte reporta-se ao processo de atualização dos currículos de formação do bibliotecário no Brasil e de como os aspectos tecnológicos e mediacionais estão presentes nos conteúdos dos documentos do MEC, da ABECIN e dos PPPs da amostra. Esta parte refere-se aos resultados da pesquisa empírica e ao modelo/proposta de uma reformatação dos fluxos de informação do currículo dos cursos de Biblioteconomia, tendo em vistas um profissional imerso na realidade na qual está inserido, mas não em forma de 
aderência, mas sim, numa perspectiva de criticidade diante do mundo. São analisados e, posteriormente, comparados os documentos do MEC, da ABECIN e os projetos pedagógicos dos cursos de Biblioteconomia da UFPA, UFSC, UNB, USP e UFC. 


\section{SOCIEDADE DA INFORMAÇÃO: DA MODERNIDADE AO CONTEMPORÂNEO}

Mudar de teoria é o mesmo que reconstruir um barco, tábua a tábua, em alto-mar. Temos um lugar específico (e um plano de olhar), mas não um olhar fixo ou fora para ver as teorias. Melhores ou piores, as teorias somos nós, a passar no espelho de nossa prática científica, dentro do espelho maior da nossa prática de cidadãos.

Neurath (1882-1945).

Para falar da formação dos profissionais da informação/bibliotecários no contexto contemporâneo é preciso que esta fala esteja situada num determinado contexto social, histórico e epistemológico. Nesse sentido, é necessário que se estabeleça um norte do olhar em relação às teorias que fundamentam nosso pensar acerca da formação do bibliotecário situado num determinado contexto. Portanto, foi necessário realizar um levantamento da literatura sobre a contemporaneidade, levando-se em consideração as várias conceituações para o momento contemporâneo, principalmente, as de modernidade, pós-modernidade e Sociedade da Informação.

\subsection{O advento da modernidade}

O eixo norteante de nossa análise pauta-se, num primeiro momento, no desvelamento do contexto contemporâneo, onde se realizam os processos de mediação de culturas e de informações. Portanto, realizando um percurso por alguns teóricos a fim de adentrarmos nas tessituras da contemporaneidade, percebemos que existe uma explosão conceitual e, por que não dizer, terminológica, acerca da predicação da sociedade atual. Em relação às várias predicações acerca da sociedade contemporânea, Bauman (1998, p. 30) em seu $O$ mal-estar da pós-modernidade, afirma que estamos numa era que Anthony Giddens chama de modernidade tardia; Ulrich Beck, de modernidade reflexiva; Georges Balandier, de supermodernidade e que ele chama de pós-moderna: o tempo em que vivemos agora, na nossa parte do mundo. Desta feita, nossa análise pauta-se em apenas dois conceitos, dos vários, que predicam a sociedade contemporânea, quais sejam, modernidade e pósmodernidade, e de um terceiro derivativo, Sociedade da Informação. Portanto, não se trata de um tratado histórico, mas sim, da organização de algumas ideias e referências históricas importantes para compreender processos de longa duração que desembocaram no momento atual. 
Em relação à modernidade ${ }^{1}$, ou período moderno, é consenso afirmar que é aquele marcado pela presença do Estado Liberal, o qual propiciou a solidificação do conceito de soberania, por meio da Revolução Industrial, e esta possibilitou a ascensão da burguesia e de suas ideias ao poder (CARDOSO, 1996, p. 65), ocasionando um processo de busca do sentido das coisas em si mesmas e no mundo e não mais no transcendental como outrora. Todavia, o objeto de nosso maior interesse não recai na gênese do período moderno, mas nas últimas cinquenta, sessenta décadas, as quais se denominam de período contemporâneo.

É numa tentativa de melhor compreensão acerca do que seria este contexto e se a modernidade estaria ou não superada que se nos apresenta a figura do sociólogo Zygmunt Bauman (1998, p. 20) para quem a modernidade é "a época ou estilo de vida, em que a colocação em ordem depende do desmantelamento da ordem tradicional, herdada e recebida; em que ser significa um novo começo permanente". Geralmente, a Idade Média é analisada como um período em que o mundo é mais ordenado e estabelecido pelo transcendental de uma vez por todas e qualquer rebelião a essa ordem divina dá lugar ao pecado, a um desvio de um culpado que deve ser expiado. Todavia, mesmo com as explicações sendo voltadas para a racionalidade religiosa, a Idade Média não renegou a razão humanista, haja vista que a as explicações religiosas encontravam atestação nos pregadores e na sua linguagem, geralmente grave e violenta e os pregadores atuam, nesse contexto, como educadores/mediadores utilizando-se também dos textos literários para educar. Para Cambi (1999, p. 150) “a educação e a pedagogia da Idade Média é estática e uniforme ao redor do princípio da fé cristã e da igreja como depositárias da função de magistério, que ela exerce numa cultura predominantemente oral e visual". Na mesma direção de que a Idade Média não foi um período que renegou a razão, Libera $(1999$, p. 85) afirma que:

\footnotetext{
Se considerarmos o passado com os olhos de um Aufklärer, a Idade Média é o buraco negro da cultura europeia. A razão certamente se encontra aí, mas a serviço da superstição. É a idade da argumentação, de uma razão infantil, faladora, teimosa, que discute tudo porque ignora tudo, acumula os efeitos porque não sabe ir às causas, fabrica sentido com uma série de acasos e mobiliza o tempo, os homens, as energias, as próprias instituições para explorar um mundo que não existe.
}

\footnotetext{
${ }^{1}$ Através do adjetivo moderno, assinalamos um novo regime, uma aceleração, uma ruptura, uma revolução do tempo (LATOUR, 2009, p. 15).
} 
Portanto, podemos perceber que durante a Idade Média havia sim o cultivo da racionalidade, pois não é à toa que a universidade ${ }^{2}$ é fruto desse período, e, embora ela seja uma instituição “da Cristandade”, conforme afirmou Libera (1999, p. 73), ela era, sobretudo, uma instituição autônoma. Todavia, na Baixa Idade Média, a educação/instrução sofre uma profunda transformação, haja vista o ensino superior estar se institucionalizando numa organização denominada de universitas studiorum, que se constituía de uma livre agregação de docentes e estudantes que acolhia as diversas especializações do saber e formava os profissionais necessários para uma sociedade em transformação (CAMBI, 1999, p. 152).

Se a ordem já posta no mundo, em que cada coisa tinha seu lugar prédeterminado, foi esfacelada, o que se pode perceber é que os homens, desde os tempos mais remotos, buscam uma explicação para os fenômenos naturais, como forma de entender e de melhor habitar no mundo. Mesmo com as explicações científicas, aquelas oriundas da religião e do mito ainda são realizadas até a contemporaneidade, uma vez que a ciência ainda não dá conta de explicar todos os fenômenos mundanos por meio de sua racionalidade. Mesmo assim, esse universo que está posto ao homem, escapa a toda compreensão. Não há como prever o que irá acontecer de forma exata e, foi nesse sentido, que Latour (2009, p. 13), ao comentar nossa condição de modernos, afirma que "nosso tecido não é mais inteiriço. A continuidade das análises tornou-se impossível", ou seja, a modernidade é um período em que não se tem mais certeza absoluta de nada que está posto no mundo.

Numa perspectiva de "ondas longas", o projeto sociocultural da modernidade constituiu-se, como gérmen, entre o século XVI e o final do século XVIII. Posteriormente, podemos perceber três etapas de desenvolvimento e consolidação da modernidade. A primeira etapa desse processo cobre o século XIX, ainda que descaracterizado nas duas últimas décadas como consequência da fase descendente da curva de Kondratiev ${ }^{3}$, que se iniciara em meados da década de 1870 (capitalismo liberal). A segunda vai do final do século XIX até a Segunda Guerra Mundial. A terceira inicia-se, em geral, no final da década de 1960. Em alguns países, esta terceira etapa iniciou-se um pouco mais cedo, em outros, um pouco mais

\footnotetext{
${ }^{2}$ Conforme Libera (1999, p. 139) a Idade Média inventou um tipo de homem novo, o universitário e que essa universidade medieval é o ponto de partida durável de uma divisão do trabalho cuja realidade deixa-se hoje facilmente formular: a função do intelectual moderno é crítica, é isto que o distingue do universitário. O intelectual é um ator da mudança social; o universitário, um espectador indiferente.

${ }^{3}$ Também denominada de curva do desenvolvimento capitalista é a teoria desenvolvida por León Trotsky, em paralelo às ondas longas de Nikolai Kondratiev, devido ao debate interno do Partido Comunista soviético sobre a situação econômica do capitalismo mundial e suas perspectivas em relação à revolução socialista na primeira metade da década de 1920. A curva e desenvolvimento capitalista de Trotsky aponta as fases históricas do desenvolvimento do Capitalismo a partir das variações na direção e na intensidade da constituição das forças produtivas como processo das transformações das relações de produção, da luta de classes e de outros acontecimentos e fatores não-econômicos (ARAÚJO, P., 2001, p. 9).
} 
tarde, e é nele que nos encontramos hoje, ou seja, no período do capitalismo neoliberal (SOUSA SANTOS, 1993, p. 78, grifo nosso).

Em contraposição à periodização da modernidade operada por Sousa Santos (1993), temos as formulações de Bauman (1999), o qual afirma que a demarcação temporal da modernidade é discutível, uma vez que:

a modernidade, como todas as outras quase totalidades que queremos retirar do fluxo contínuo do ser, torna-se esquiva: descobrimos que o conceito é carregado de ambiguidade, ao passo que seu referente é opaco no miolo e puído nas beiradas, de modo que é improvável que se resolva a discussão. O aspecto definidor da modernidade subjacente a essas tentativas é parte da discussão (BAUMAN, 1999, p. 12).

Em relação ao Brasil, Martins (2011, p. 41) afirma que a modernidade é marcada pelo hibridismo cultural, assim como a América Latina, conjugando o passado e o presente; portanto, os tempos históricos estão mesclados e confundidos no dia a dia, como estão confundidos e invertidos os estilos cognitivos dos diferentes mundos que demarcam a nossa vida social. É como se já fôssemos pós-modernos antes mesmo de termos chegado à modernidade, há muito misturando numa colagem desarticulada tempos históricos e realidades sociais; já diria García Canclini, é como se fôssemos pós-modernos há séculos.

A reflexão epistemológica moderna tem suas origens na filosofia do século XVII e atinge um dos seus pontos altos em fins do século XIX, ou seja, no período em que acompanha a emergência e a consolidação da sociedade industrial e assiste ao desenvolvimento espetacular da ciência e da técnica. A consciência epistemológica foi, durante esse longo período, uma consciência arrogante provocando o deslocamento da prima philosophia do lugar central que esta ocupara desde Aristóteles na filosofia ocidental, substituindo-a pela filosofia da ciência. Durante muito tempo, a reflexão epistemológica parece ter sido menos o reflexo da crise do que a tentativa de negá-la ou, quando muito, de superá-la a favor do status quo científico. Essa discussão sobre a natureza das crises da ciência tem toda a acuidade no período que vivemos e cujo início, para este efeito, situa-se já no imediato pós-guerra. Decorre dessa afirmação a pergunta acerca de estarmos, ou não, numa crise de crescimento ou de degenerescência da ciência moderna (SOUSA SANTOS, 1989, p. 17-19).

O mundo pensado matematicamente e de forma mecânica, onde tudo tinha causa e efeitos bem determinados, foi o paradigma dominante até o início do século XX. A visão mecanicista de mundo fez com que a física se tornasse a base de todas as outras ciências, 
inclusive as sociais, que proclamaram terem descoberto a física social. Desta feita, para a ciência moderna, conforme o pensamento de Sousa Santos (1989), todo conhecimento que não pudesse ser comprovado matematicamente, e nem pela racionalidade, não seria válido e, é neste cenário, que nascem as Ciências Sociais; ou seja, num período marcado pela supervalorização dos conhecimentos comprovados matemática e fisicamente. Neste ínterim, as Ciências Sociais passam a ser influenciadas pelas Ciências Naturais, sendo, portanto, concebidas para serem empíricas e, por conseguinte, o ser humano passa a ser observado na sua subjetividade, na sua constituição sócio-histórica e cultural por algumas correntes de pensamento.

Ainda em relação às Ciências Sociais, podemos perceber que o seu berço foi a França, uma vez que a Revolução de 1789 acarretou pressões para transformações políticosociais decorrentes do surto cultural desencadeado pela revolução. Este fato abriu espaço para o surgimento das Ciências Sociais; em primeiro lugar, para organizar e racionalizar a mudança social e de outro para estudá-la e entender as regras subjacentes. Portanto, as ciências sociais tomaram, nesse momento, a física newtoniana como modelo (ALMEIDA, M., 2007, p. 97). É nesse contexto, que se apresentam as proposições metodológicas de Émile Durkheim (1987) para a análise dos fatos sociais. A primeira dessas formulações é: tratar os fatos sociais como coisas. Para o formulador de tal proposição, é necessário descartar dos fatos sociais todas as pré-noções, o que é a base de todo o método científico por ele proposto; ou seja, o pesquisador social deve deixar de lado suas crenças, suas opiniões, pois elas perturbam a análise dos fatos sociais e a atenção deve ser dada aos fatos e não às ideologias. Outra forma de analisar os fatos sociais é empreender um estudo objetivo deles, portanto, o estudo para ser objetivo deve exprimir os fenômenos, não a partir da ideia que se faz dele, mas das propriedades que lhes são inerentes.

Todavia, a modernidade não acarretou transformações apenas no cenário científico, mas, sobretudo pelas amplas transformações no âmbito social, político, econômico e cultural ocorridas, principalmente, a partir da Revolução Industrial. Por exemplo, na Primeira Revolução Industrial, a técnica precedia a ciência e temos como exemplo a máquina a vapor que precedeu a teoria da termodinâmica (era um movimento que ia do mundo das fábricas para depois serem estudados pela universidade). Já na Segunda Revolução Industrial a ciência precedeu a técnica, ou seja, a ciência, principalmente a Química e a Física, passou a desenvolver produtos que passaram a ser absorvidos nas indústrias para a melhoria da produção. É nesse período que se passou a utilizar a Administração Científica do engenheiro estadunidense Frederick Taylor no interior das fábricas. Contudo, foi apenas na Terceira 
Revolução Industrial que a ciência precedendo a técnica atingiu seu apogeu, e foi baseada nas transformações da microinformática iniciadas na década de 1960. Entretanto, já podemos falar, juntamente com Almeida, P. (2005), que estamos no bojo de uma quarta revolução industrial, pois, a cada dia, percebemos o avanço da biotecnologia, que mobiliza as ciências da vida e várias outras ciências, sob a forma de nanociência (portanto, nesse momento, há um acirramento da ciência precedendo a técnica, pois o mundo mercadológico passa a financiar e, muitas vezes, a ditar quais pesquisas devem ser realizadas no âmbito das universidades com vistas à inovação e à aceleração da produção).

Em relação à Revolução Industrial, desde a sua primeira versão, percebemos que tem por base a inovação e a sofisticação dos produtos fabricados, como uma de suas consequências; a urbanização cresce a passos velozes, o que ocasiona o caos urbano nas grandes metrópoles, o crescimento cada vez mais acelerado das cidades, que passam a ocupar ainda mais espaço, diminuindo o litoral e o campo; o desenvolvimento tecnológico produz inovações a cada segundo; o meio ambiente é devastado, tanto a fim de suprir as necessidades do capital, quanto como consequência das ações da indústria, com fins de transformação da matéria-prima. Ou seja, na modernidade predomina o modo de produção capitalista e a modernização é o processo de desenvolvimento da sociedade moderna, mesmo com todas as consequências que ela acarreta. Ela é a fase atual do desenvolvimento do capitalismo, ou seja, a contemporaneidade (VIANA, 2009).

Do ponto de vista cultural, a modernidade também transformou a estética da época, e um dos grandes nomes da estética do modernismo, cuja paternidade, geralmente, é dada a ele, é o poeta Charles Baudelaire, o qual detestava uma visão entorpecida do mundo em poemas ou quadros convencionais, ao mesmo tempo em que, como os mais sofisticados românticos, não tinha paciência com subjetividades desenfreadas; portanto, foi pioneiro, inclusive na criação do princípio vanguardista sobre a necessidade de ser contemporâneo, e de que o artista criativo não deveria ficar preso à Antiguidade Clássica, ao medievalismo de cavalaria ou aos idílios bucólicos que dominaram a paisagem cultural por séculos. Mas a vitória do novo ainda não era certeza. Havia a influência e a persistência dos consumidores que confiavam cegamente na tradição e preferiam de bom grado o kitsch de fácil digestão ao trabalho mais árduo de proporcionar um prazer estético duradouro (GAY, 2009, p. 115). Esta formulação de Peter Gay (2009) vem ao encontro do pensamento da filósofa Hannah Arendt ${ }^{4}$, a qual afirma, em tom de lamento, que:

\footnotetext{
${ }^{4}$ Obra publicada, originalmente, em 1954.
} 
Podemos elevar-nos acima da especialização e do filisteísmo de toda natureza na proporção em que aprendamos como exercitar livremente nosso gosto. Saberemos, então, como replicar àqueles que com tanta frequência nos dizem que Platão ou algum outro grande autor do passado foi superado; seremos capazes de compreender que, mesmo que toda crítica a Platão esteja correta, Platão ainda será melhor companhia que seus críticos. De qualquer maneira, podemos recordar aquilo que os romanos- o primeiro povo a encarar seriamente a cultura, à nossa maneirapensavam dever ser uma pessoa culta: alguém que soubesse como escolher sua companhia entre homens, entre coisas e entre pensamentos, tanto no presente como no passado (ARENDT, 2009, p. 280-281).

Embora sempre houvesse os que preferissem os gostos artísticos mais tradicionais, também sempre houve outros que preferiam as formulações artísticas que estavam surgindo em seu tempo e que pareciam apontar para uma nova etapa societal, para alguns, ainda, moderna; para outros, não mais, talvez, ultramoderna, pós-moderna. Contemporaneamente, não foram apenas as mudanças no contexto cultural que apontavam para uma nova era histórica, mas sim, as transformações nos contextos sociais (com as Tecnologias de Informação e de Comunicação, principalmente, porque elas transformam os processos de mediação da informação e da própria cultura, propiciando o surgimento de uma Sociedade da Informação), políticos (pois os atores sociais encontram nas tecnologias formas alternativas de exercerem o poder), econômicos (com a criação de redes de bancos comunitários, que se percebem como alternativas à sociedade imposta), dentre outras formas de ações que nos fazem pensar que há um acirramento das características da modernidade e que, até mesmo, ultrapassam essa etapa histórica e social, denominada por alguns autores de pós-modernidade. Assim, cabe esclarecer que, falar em pós-modernidade, não necessariamente implica em "defender" o fim da modernidade, mas sim em afirmar que as transformações sociopolíticas, econômicas e culturais foram tão intensas que já não cabe mais denominar o atual período de modernidade, mas, talvez de “pós”-modernidade.

\subsection{Pós-Modernidade: ruptura ou continuidade?}

Com as mais diversas transformações nos âmbitos do social, do político, do econômico, do tecnológico e com as novas descobertas científicas, surgiram muitas formulações a respeito de que a sociedade dos pós-guerras estaria adentrando numa nova etapa societal. Vários autores vêm, tanto corroborar, quanto problematizar esta afirmação, tanto no que diz respeito a que essa etapa mais contemporânea seja uma nova etapa societal, que é complemente diferente da anterior, denominada de moderna; quanto no que diz respeito 
a que essa etapa seja apenas mais uma das várias etapas pelas quais já passou a sociedade. Para os segundos, devido ao fato de não haver grandes rupturas de ordem econômica, como quando da passagem das sociedades feudais para a capitalista, ela não seria outra etapa social, mas apenas um acirramento da fase anterior.

Um autor que vem a corroborar que a pós-modernidade é uma despedida da modernidade é Vattimo (1996, p. VII), para quem "o pós de pós-moderno indica, com efeito, uma despedida da modernidade, que, na medida em que quer fugir das suas lógicas de desenvolvimento [...], busca, o que Nietzche e Heidegger procuraram em sua peculiar relação ‘crítica' com o pensamento ocidental”. Em oposição, encontramos o pensamento de Latour (2009, p. 50-51) para quem o mundo moderno jamais existiu; pelo menos, no sentido de que jamais funcionou de acordo com as regras de sua constituição. $\mathrm{O}$ autor não acredita que a pósmodernidade seria uma nova era totalmente diferente da era moderna e ainda afirma que o que estamos vivenciando seria um momento não-moderno (ou amoderno). Ou seja, para Latour (2009, p. 73) "os pós-modernos conservam o panorama moderno, mas dispersam os elementos que os modernizadores agrupavam em um pelotão bem-ordenado". Seria, portanto, o desmantelamento dos elementos característicos da modernidade.

Em contraposição aos autores supracitados, encontramos Sousa Santos (1987) que afirma estarmos num período de transição de paradigmas e que se apresenta como uma crise do entendimento e do próprio projeto da modernidade. Portanto, para o referido autor, esse paradigma, que ainda não se sabe ao certo qual é, mas que ele prefere denominá-lo de pósmoderno ${ }^{5}$ está em construção e, por meio dele, deve-se buscar um novo paradigma capaz de responder às questões que a modernidade não consegue responder.

Historicamente, o que se convencionou denominar de pós-modernismo surgiu pela primeira vez no mundo hispânico, na década de 1930, antes de seu aparecimento na Inglaterra e nos Estados Unidos. Perry Anderson (1999), em seu livro As origens da pósmodernidade conta que foi um amigo de Unamuno e Ortega, Frederico de Onís ${ }^{6}$, que usou o termo pela primeira vez, embora descrevendo um conservadorismo dentro do próprio modernismo. O termo reapareceu somente no final dos anos de 1950, como indicação

\footnotetext{
${ }^{5}$ Sousa Santos (1987) utilizava esta denominação por achar que não havia outra melhor no momento. No entanto, ele insiste no seu pós-modernismo, denominado por ele "de oposição" e o pós-modernismo em voga, classificado como de exaltação. Enquanto o pós-modernismo de oposição orienta suas ações para a efetivação de um novo paradigma voltado para a emancipação do indivíduo; o pós-modernismo celebratório concebe a própria crise como um momento de transformação social contínuo, sem a necessidade de constituição de um novo modelo geral, não diferenciando, assim, as diferenças entre teorias emancipatórias e regulatórias.

${ }^{6}$ Catedrático de Literatura Espanhola na Universidade de Olviedo e na Universidade de Salamanca. Colaborador do Centro de Estudos Históricos. Na obra Antologia da poesia espanhola e hispanoamericanas (1934) define pela primeira vez o que é a estética literária do Pós-modernismo e mesmo do Modernismo.
} 
negativa do que era menos, não mais, moderno. Todavia, a noção de pós-moderno só ganhou difusão mais ampla a partir dos anos de 1970, mais precisamente, quando do lançamento, no outono de 1972, de uma publicação que trazia expressamente o subtítulo: Revista de Literatura e Cultura Pós-Modernas- o periódico Boundary 2 [Fronteira 2], cujo ensaio-chave, na primeira edição, foi de autoria de David Autin e intitulava-se Modernismo e Pósmodernismo: abordando o presente na poesia americana. Entre os primeiros colaboradores da revista encontramos: Ihab Hassan que publicou seu primeiro ensaio sobre o pósmodernismo um pouco antes do lançamento da Revista Boundary 2. É nesse momento que temos o surgimento daquilo que denominamos de uma epistemologia pós-moderna. As ideias de Hassan acerca do pós-modernismo foram lançadas em 1971 e esse conceito estendeu-se ao domínio das artes visuais, da música, da tecnologia e da sensibilidade em geral.

Originalmente, o termo pós-moderno significava a perda da historicidade e o fim da grande narrativa. Somente em 1974, o termo "pós-moderno" entrou para o mundo da arte em Nova Iorque, onde talvez o primeiro arquiteto a usá-lo tenha sido Robert Stern, um aluno de Venturi, e a primeira obra filosófica a adotar a noção foi A Condição Pós-moderna, de Lyotard, publicada em Paris, no ano de 1979. Jameson (2007) enumera cinco ícones desse movimento pós-modernista: na arte, Andy Warhol e a pop art, o fotorrealismo e o neoexpressionismo; na música, John Cage, mas também a síntese dos estilos clássico e popular que se vê em compositores como Philip Glass e Terry Riley e, outrossim, o punk rock e a new wave; no cinema, Godard; na literatura, William Burroughs, Thomas Pynchon e Ishmael Reed, de um lado, e o nouveau roman francês e sua sucessão, do outro. Na arquitetura, entretanto, seus problemas teóricos são mais consistentemente articulados e as modificações da produção estética são mais visíveis.

Numa tentativa de diferenciar o termo pós-modernidade de pós-modernismo, Eagleton $(1998$, p. 7) afirma que o pós-modernismo refere-se, em geral, a uma forma de cultura contemporânea, enquanto o termo pós-modernidade alude a um período específico da história. Para o referido autor, a pós-modernidade "é uma linha de pensamento que questiona as noções clássicas de verdade, razão, identidade e objetividade, a ideia de progresso ou emancipação universal, os sistemas únicos, as grandes narrativas ou os fundamentos definitivos de explicação". Portanto, o pós-modernismo põe em suspensão todas as categorias que a modernidade ressaltou, tanto em seu projeto social, quanto em sua epistemologia.

Grande expoente do pensamento pós-moderno, Michel Foucault (2008), na obra $A$ arqueologia do saber, publicado originalmente em 1969, propõe que a história não deve ter esse sentido de continuidade e de memória, pois as metanarrativas são totalizantes. Por isso, o 
historiador deve agir apenas como arqueólogo do passado, escavando vestígios, classificandoos e depositando-os no museu do conhecimento. Para Foucault (2008, p. 6), a história, na contemporaneidade, volta-se para a arqueologia, para a descrição intrínseca do monumento; a noção de descontinuidade toma um lugar importante nas disciplinas históricas e, por fim, o tema e a possibilidade de uma história global começam a se apagar para se esboçar uma história geral. Ou seja, para o referido autor, a história deve ser tratada em micronarrativas, o que, para Jameson (2007), teórico marxista, tornar-se-ia uma metanarrativa de uma micronarrativa. O referido autor justifica seu pensamento afirmando que:

[...] se percebe que Marx ou Nietzsche não asseguram a salvaguarda que se lhes tinha confiado. Não se deve mais contar com eles para proteger os privilégios, nem para afirmar, uma vez mais- e, entretanto, só Deus sabe se se teria necessidade disso na aflição de hoje-, que a história, pelo menos ela, é viva e contínua; que ela é, para o tema em questão, o lugar do repouso, da certeza, da reconciliação- do sono tranquilizado (FOUCAULT, 2008, p. 17).

Outro autor cujas reflexões se alinham às teorias da pós-modernidade é Gilles Deleuze (1996). Em Conversações, a qual reúne cartas e entrevistas por ele concedidas ao longo do tempo, o autor inicia afirmando que pertence a uma geração, a uma das últimas gerações, que tem sido mais ou menos assassinada pela história da filosofia, pois esta tem uma evidente função repressiva. Ele compara a geração a qual pertence com o Édipo propriamente filosófico: não ousarás falar em teu próprio nome até que não tenhas lido isto ou aquilo, e sobre aquilo e aquilo sobre isto (DELEUZE, 1996, p. 16). Deleuze, em seguida, afirma que, dos filósofos da sua geração, alguns não conseguiram se libertar, outros conseguiram e inventaram seus próprios métodos e regras novas e ensaiaram um tom diferente. Nesta obra, o filósofo afirma que nem Marx, nem Freud despertaram em alguém o prazer que cada um pode experimentar dizendo coisas simples em seu próprio nome, falando de afetos, intensidades, experiências, experimentações, pois ambos tiveram de se pautar na filosofia de seu tempo (DELEUZE, 1996, p. 9). Ou seja, as bases sobre as quais Marx, Freud, e outros autores modernos se pautaram têm de ser desintegradas e, igualmente, a própria tradição, no campo científico, estava sendo esfacelada a partir de um pensamento pósmoderno. A partir desse momento entramos numa era de crise de representações, uma vez que tivemos os nossos referenciais destruídos. A partir daquele momento, cada um, a partir de suas próprias ideias, poderia formular suas explicações acerca dos fatos sociais, a partir de narrativas minimizadas, sem necessidade de se reportar aos autores passados. 
Todavia, já podemos perceber esses processos no início da modernidade, conforme já afirmamos anteriormente. O que passa a ocorrer na pós-modernidade é que esses processos foram acirrados, devido à aceleração que as novas mídias eletrônicas trouxeram para o seio societal. Tecendo um diálogo com Hannah Arendt, tudo aquilo que os nossos antepassados nos legaram para o futuro, foi-nos deixado sem testamento, sem tradição, portanto, sem necessidade de continuidade. Conforme as palavras da filósofa:

\begin{abstract}
O testamento, dizendo ao herdeiro o que será seu de direito, lega posses do passado para o futuro. Sem testamento, ou resolvendo a metáfora, sem tradição - que selecione e nomeie, que transmita e preserve, que indique onde se encontram os tesouros e qual o seu valor - parece não haver nenhuma continuidade consciente no tempo e, portanto, humanamente falando, nem passado nem futuro, mas tão-somente a sempiterna mudança do mundo e o ciclo biológico das criaturas que nele vivem (ARENDT, 2009, p. 31).
\end{abstract}

No campo da cultura, o pós-modernismo significou que não existe mais- ou, pelo menos, que seria difícil traçar- uma linha demarcatória entre alta e baixa cultura, ou entre a cultura de massa e a prática da apropriação e da citação de obras do passado. De um lado, a cultura global (consumismo, Hollywood, disco sound, fast food, cultura comercial, mass media globais), do outro, as culturas locais (movimentos comunitários indigenistas, afirmação de direitos ancestrais de línguas e culturas até agora marginalizadas) e as culturas regionais (por exemplo, na Índia, na Itália e, entre nós, a emergência do regionalismo nortenho) (SOUSA SANTOS, 1986, p. 144-145). A pós-modernidade põe em xeque toda perspectiva de universalidade advinda com o iluminismo e isso recai na ciência na medida em que ela questiona metodologias como o positivismo e o marxismo, conforme vimos em alguns autores supracitados como no caso de Deleuze (1996).

Um dos autores críticos à pós-modernidade, bem como à epistemologia pósmoderna, é David Harvey, de forma especial, no livro Condição pós-moderna, obra na qual o autor realiza uma crítica à pós-modernidade parafraseando o título da obra de Lyotard $A$ Condição pós-moderna (obra propulsora do ideário pós-moderno na contemporaneidade). Harvey (2000, p. 19) afirma que a pós-modernidade constitui-se numa "espécie de reação ao modernismo ou de afastamento dele”. Ou seja, a pós-modernidade não é um estágio societal em que o modernismo tenha sido suplantado e, em seu lugar, tenha surgido outra sociedade para além do modernismo. Pelo contrário, em lugar dos discursos totalizantes, característica do pensamento moderno, que objetivava o alcance de outra sociedade, o pensamento pósmoderno tem como marco fundamental a exaltação da fragmentação, da indeterminação, da rejeição das "metanarrativas" (interpretações teóricas de larga escala pretensamente de 
aplicação universal). Neste sentido, Harvey (2000, p. 49) afirma que o pós-modernismo é a "total aceitação do efêmero, do fragmentário, do descontínuo e do caótico que formavam uma metade do conceito baudelairiano de modernidade". Ou seja, o que se denomina de pósmodernidade é o acirramento das características da modernidade em uma continuidade histórica. Mas, diante do contexto da pós-modernidade, como os pós-modernos acreditam que devemos agir? Harvey (2000, p. 55) responde afirmando:

\begin{abstract}
Mas se, como insistem os pós-modernistas, não podemos aspirar a nenhuma representação unificada do mundo, nem retratá-lo com uma totalidade cheia de conexões e diferenciações, em vez de fragmentos em perpétua mudança, como poderíamos aspirar a agir coerentemente diante do mundo? A resposta pós-moderna simples é de que, como a representação e a ação coerentes são repressivas ou ilusórias (e, portanto, fadadas a ser autodissolventes e autoderrotantes), sequer deveríamos tentar nos engajar em algum projeto global. O pragmatismo (do tipo de Dewey) torna-se, então, a única filosofia da ação possível.
\end{abstract}

Um dos teóricos críticos da pós-modernidade é Jameson (2007) que desenvolve uma teoria da lógica cultural do capital. O referido autor afirma que a modernidade também se preocupava com o novo de forma compulsiva, todavia, o pós-modernismo busca rupturas, busca eventos em vez de novos mundos, busca o instante revelador depois do qual nada mais foi o mesmo. Para Jameson (2007, p. 17) a história de sucesso da palavra pós-modernismo deveria, sem dúvida, ser escrita em forma de Best-seller; neoeventos léxicos desse porte, nos quais a cunhagem de um neologismo tem o mesmo impacto de realidade da fusão de duas empresas. Além de Jameson (2007) existem outros autores que se colocam do outro lado do fio da navalha dos estudos acerca da pós-modernidade, analisando-a a partir de uma perspectiva crítica. É nesse contexto que encontramos García Canclini (2007) o qual, ao analisar a pós-modernidade, a partir da perspectiva de como se encontram os sujeitos dentro de uma sociedade pós-moderna, afirma que:

O pensamento pós-moderno redefine os sujeitos como nômades. Baseado nas
experiências de migrantes, artistas e exilados, e sem levar muito em conta as
estruturas econômicas e socioculturais, os fluxos de mensagens e bens que
possibilitam a experiência nômade, estes autores exaltam a desterritorialização e
veem o enfraquecimento dos laços de pertencimento nacionais e locais como uma
libertação (Deleuze, Guattari, Lyotard). Em vez de estruturas duráveis de
sentimentos, a relocalização tática de experiências e condutas (GARCÍA
CANCLINI, 2007, p. 202).

Portanto, os sujeitos da pós-modernidade passam a ter suas experiências enquanto sujeitos na rede, de forma conectada, o que o possibilita a fragmentação de sua identidade, 
pois o indivíduo pode se apresentar de formas diferentes para pessoas diferentes no ambiente on line. Configura-se, a partir daí, o que Bauman (2005, p. 96) afirmara ser a identidade líquida, ou seja, aquela que está sempre em mutação, pois “comprometer-se com uma única identidade para toda a vida, ou até menos do que a vida toda, mas por um longo tempo, é um negócio arriscado. As identidades são para usar e exibir, para armazenar e manter”.

Outra faceta societal onde podemos perceber a liquidez dos tempos contemporâneos é na gênese do que Bauman (2001) denomina de modernidade líquida, que acontece quando o espaço e o tempo são separados entre si, e a velocidade passa a fazer parte de forma cada vez mais intensa do cotidiano societal. As distâncias passaram a ser mediadas pelas Tecnologias de Informação e de Comunicação, fazendo com que a velocidade e o tempo para chegarmos a determinado lugar sejam cada vez mais diminuídos e, a partir de Einstein, esses conceitos de tempo espaço absolutos passam a ser contestados, além de as medidas de distância e tempo passarem a depender do movimento do observador. Vemos, portanto, a emergência do ciberespaço (com um espaço onde se fala de fluxos e não como algo estanque) e de um tempo intemporal, que já não se faz mais com experiências, com relações interpessoais, mas que pode ser denominado de não-tempo ${ }^{7}$, ou seja, é um tempo que não podemos relacionar a eventos vividos, que não lhes conferimos uma identidade e parece perdido na história. Com as Tecnologias de Informação e de Comunicação quiçá, transferiremos nossas mentes para os computadores e viveremos para sempre no espaço digital, fazendo-nos imortais, que é o sonho que vem percorrendo os homens desde os tempos mais remotos.

Essa velocidade perpassa as nossas relações constituindo o que Bauman (2004, p. 8) denomina de amor líquido, ou seja, relações cujos "sólidos estão em estado avançado de desintegração". Podemos exemplificar tal fato com os relacionamentos mantidos por meio da Internet, que passam a ser quase-interações mediadas pelos sites de relacionamentos, dentre os quais, o Facebook, Orkut, Twitter e outros. Nesses locais, quanto mais "amigos", ou seguidores você tiver, mais bem relacionado você e aqueles que fazem parte de seu grupo se considera. Todavia, são relações que podem vir a se liquefazer em instantes, basta apertar o botão delete do computador. Portanto, "às sociedades em que isto acontece deu-se o nome de ‘sociedades do espetáculo' para indicar sua natureza alucinatória, por não se ligar ao real e

\footnotetext{
${ }^{7}$ Não-tempo, conforme usamos nesta investigação, refere-se à categoria antropológica de tempo, ou seja, um tempo não experienciado, não vivido, mas criado junto a uma vivência simulada. É um tempo provisório, efêmero, vivido com solidão. Mesmo que com as tecnologias midiáticas, que derrubaram as barreiras do espaço e do tempo, as pessoas estejam ligadas umas às outras, independentemente do lugar e do tempo em que estejam, essas experiências vividas são esvaziadas de sentido, pois basta desligar o computador que as pessoas retornam à sua condição existencial. Para maiores detalhes ver Augé (1994).
} 
sim ao 'hiperrealismo', cuja pretensão é ser mais real que o real, ou mesmo substituí-lo" (MATOS, 2010, p. 124).

Essas relações de descartabilidade das relações e das identidades são oriundas, outrossim, de uma cultura do descartável na economia. Nada mais é feito para durar. A roupa que você compra hoje é usada apenas por alguns meses, pois, de forma muito rápida, chega a próxima estação ditando novas tendências. A moda passa a ditar o que devemos ou não vestir e quem não estiver incorporado é como se não fizesse parte da sociedade. Este fenômeno vem ocorrendo tanto no mundo das coisas, quanto no mundo das pessoas. Podemos verificar que até mesmo Marx (2003), já havia previsto o que foi analisado por Bauman (2005) e em outros escritos, ou seja, a descartabilidade a qual no contexto daquele se dava em relação ao trabalhador. Este se tornou descartável, depois do predomínio das tecnologias nas indústrias. Essa cultura do descartável da economia produz o refugo humano, ou seja, os excessivos, os redundantes, que é um produto inevitável da modernização, e um acompanhante inseparável da modernidade. Ser redundante é ser desnecessário, ou seja, os outros não necessitam de você. Redundância compartilha o espaço semântico de "rejeitos", "dejetos", "restos", "lixos"com refugo (BAUMAN, 2005). A cultura do descartável, bem como o domínio do capital sobre o trabalho, pode ser verificada através de alguns regimes de trabalho, dentre eles, o trabalho terceirizado, ou aquele no qual "você é o seu próprio patrão". Se antes tínhamos certas estruturas duráveis, tanto de relações no mundo do trabalho, da escola, das relações afetivas; na atualidade, essas certezas são postas por terra e passam, conforme palavras weberianas, a ser “desencantadas". Em palavras marxianas:

A contínua revolução da produção, o abalo constante de todas as condições sociais, a incerteza e a agitação eternas, distinguem a época burguesa de todas as precedentes. Tudo o que é sólido e estável se volatiliza, tudo o que é sagrado é profanado, e os homens são finalmente obrigados a encarar com sobriedade e sem ilusões sua posição na vida, suas relações recíprocas (MARX, 2003, p. 48).

Percebemos que a expansão dos mercados, além de ocorrer no espaço, também ocorre no tempo, porque se efetiva mediante a aparente negação da temporalidade (aparente sim, pois o tempo não deixa de existir só porque ele é negado, ele vira um não-tempo) que é a obsolescência planejada dos produtores, a fim de poder vender outros produtos. A cultura do instantâneo, sem história, está relacionada com a instabilidade dos movimentos de investimentos e lucros, renováveis nas cotações de cada dia e imprevisíveis no dia seguinte, que ocultam as políticas de gestão dos capitais e dos seus concretos dispositivos ou estruturas (fábricas, bancos, controle dos meios de transporte e dos circuitos para transmitir mensagens) 
(GARCÍA CANCLINI, 2007). Como exemplo dessa cultura do instantâneo do mundo das coisas, temos que:

\begin{abstract}
Na Grã-Bretanha, produzimos a cada ano cerca de um milhão de tonelada de refugo eletrônico, esperando dobrar esse volume à altura de 2010. Os equipamentos eletrônicos, não muito tempo atrás, alinhados entre os bens mais valiosos e duráveis, são agora eminentemente descartáveis e feitos para virar lixo- e rapidamente. As empresas de marketing aceleram seu trajeto rumo à obsolescência "tornando os produtos permanentemente defasados ou criando a impressão de que, se não se mantiver em dia, você é que será defasado" (BAUMAN, 2005, p. 77).
\end{abstract}

Essa cultura do instantâneo, que faz com que as mercadorias/coisas tenham de ser feitas de forma muito rápida, igualmente é analisada pela filósofa Olgária Matos (2009), para quem, nos tempos atuais, a hiperatividade das pessoas significa fazer muitas coisas com nenhum sentido e que as pessoas querem matar o tempo porque não sabem o que fazer com o tempo livre; o tempo é preenchido pelas coisas, é um tempo especializado. Portanto, esse tempo especializado também atravessou os muros das academias, pois a pesquisa, cada vez mais, é praticada a partir da lógica mercadológica, sendo convertida em produção, fazendo-a com pressa, muitas vezes em série; e, consequentemente, produzindo conhecimentos, da mesma forma como são produzidas as mercadorias, ou seja, com uma característica, também, de obsolescência, portanto:

\footnotetext{
A universidade pós-moderna não lida mais com as "grandes narrativas", nem busca a fundamentação do conhecimento e seus primeiros princípios. Como o mercado, se pauta pela mudança incessante de métodos e pesquisas. Nada aprofunda, produzindo uma cultura da incuriosidade, imune ao maravilhamento. Em sua pulsão antigenealógica, acredita que tudo o que nela se desenvolve deve a si mesma, não reconhecendo nenhuma dívida simbólica com as gerações passadas. Essa circunstância, por sua vez, pode ser compreendida no âmbito da massificação da cultura e da universidade (MATOS, 2009, p. 2).
}

No campo das ciências, na pós-modernidade, podemos perceber que elas não se pautam mais em modelos mecanicista de natureza e de sociedade e, já no século XIX, iniciase uma tendência de pensamento que suplanta a imagem da máquina do mundo newtoniana. Ela envolve a ideia de evolução, mudança e crescimento. Nesse período, duas descobertas no campo da física culminaram na teoria da relatividade e na teoria quântica, pulverizando os principais conceitos da visão de mundo cartesiana e da mecânica newtoniana, e Einstein marca o começo do pensamento do século XX. É a partir de suas ideias de que o universo deixa de ser um todo dinâmico, indivisível, cujas partes são inter-relacionadas e que os átomos são constituídos de vastas regiões onde os elétrons se movimentam ao redor do núcleo 
e que as unidades subatômicas da matéria são entidades muito abstratas e tem aspecto dual (ora são partículas-e as partículas de luz Einstein chamou de quanta-, ora são ondas), que a noção de complementariedade tornou-se parte essencial como os físicos pensam a natureza e o próprio Borh sugeriu ser esse conceito (de complementaridade) útil também fora do campo da física (CAPRA, 2001). Essa dualidade do elétron implica que não é mais possível formar uma representação clara do que está acontecendo no decorrer do mundo físico, além de que não é mais possível prever com exatidão o que ocorrerá quando fizermos uma observação. Portanto, a física clássica descreve um mundo que é claro e determinado. A física quântica descreve um mundo que é nebuloso e intermitente (POLKINGHORNE, 2011).

Para Sousa Santos (1987, p. 9) as principais características de uma ciência pósmoderna, são as seguintes proposições: 1) começa a deixar de fazer sentido a distinção entre ciências naturais e ciências sociais; 2) a síntese que há de operar entre elas tem como polo catalisador as ciências sociais; 3) para isso, as ciências sociais terão de recusar todas as formas de positivismo lógico ou empírico ou de mecanicismo materialista ou idealista com a consequente revalorização do que se convencionou chamar humanidades, ou estudos humanísticos; 4) esta síntese não visa uma ciência unificada nem sequer uma teoria geral, mas tão-só um conjunto de galerias temáticas onde convergem linhas de água que até agora concebemos como objetos teóricos estanques; 5) à medida que se der esta síntese, a distinção hierárquica entre conhecimento científico e conhecimento vulgar tenderá a desaparecer e a prática será o fazer e o dizer da filosofia da prática.

Além de todas as transformações operadas nos mais variados aspectos da vida humana e social, o momento contemporâneo, ou pós-moderno, também alterou as várias formas de identidade dos seres sociais. Se outrora, o sujeito tinha uma identidade estável, na pós-modernidade, conforme Hall (2002, p. 7) "as velhas identidades que, por tanto tempo, estabilizaram o mundo social, estão em declínio, fazendo surgir novas identidades e fragmentando o indivíduo moderno, até aqui visto como unificado". No âmbito das várias profissões no mundo contemporâneo estamos percebendo essa crise de identidade. Com as Tecnologias de Informação e de Comunicação, as quais tomaram conta do ser e do estar do indivíduo no mundo, bem como os avanços das ciências que criaram novas áreas, novas formas de sociabilidade, as identidades dos indivíduos se encontram cada vez mais fluidas, fazendo com que os sujeitos assumam várias formas identitárias dependendo do ambiente societal no qual ele está inserido.

Em relação ao Brasil, a discussão acerca da pós-modernidade limitou-se muito mais às questões de forma, sem discutir, portanto, os aspectos sociais, econômicos, históricos, 
políticos e educacionais condicionantes dos processos culturais e artísticos do pósmodernismo e da pós-modernidade no Brasil. Portanto, além das mais variadas mídias que, devido ao processo de globalização, estão adentrando e se desenvolvendo no País, a pósmodernidade brasileira se expressa na cultura, quando presenciamos a mistura de estilos musicais, como, por exemplo, o tecnobrega, que se constitui numa mistura da música brega paraense, com as batidas eletrônicas do Techno. Essas hibridizações, para usar os termos de García Canclini (1997), são favorecidas, principalmente, pelos meios e pelas mediações sociotécnicas da contemporaneidade, haja vista elas quebrarem fronteiras de espaço e de tempo, promovendo, ou facilitando as hibridizações culturais. Portanto, passamos a ser assediados por signos e formas simbólicas produzidas em diversas partes do mundo e que são postas em circulação em qualquer lugar do planeta. Essas mudanças afetam não apenas os seres em si (que tem suas identidades, também, hibridizadas), mas a sociedade como um todo e a nossa forma de pensar acerca dela.

Podemos observar até aqui a profusão de conceitos que envolvem o momento contemporâneo. Nesse ínterim, perguntarmo-nos: qual a relação existente entre uma sociedade denominada pós-moderna, que tem por base, também, a informação, daí ser chamada de Sociedade da Informação, e a emergência de uma ideologia econômica denominada de neoliberalismo?

\subsection{Sociedade da Informação, Economia e Neoliberalismo}

Realizando um passeio panorâmico pelo contexto contemporâneo, podemos perceber que as transformações identitárias promovidas pela pós-modernidade, e da qual fala Hall (2002), alteraram o ser físico e social das pessoas, constituindo novos tipos de organizações sociais, bem como novos tipos de sociedades. Se a informação, conforme afirmou Barreto (1994), é um elemento que dá sentido ao mundo, independentemente de ela ser onda (imaterial) ou partícula (material), e auxilia a evolução e a revolução do homem em direção à sua história, tanto por meio de sua identidade genética, quanto durante a existência pela sua competência em elaborar a informação, para estabelecer a odisseia humana individual no espaço e no tempo; portanto, podemos perceber que a informação, mesmo em forma imaterial, como nos primórdios da humanidade, já auxiliava o homem a desvendar o mundo ao seu redor. No entanto, foi apenas com a Segunda Guerra Mundial, que a informação passou a ser um insumo na sociedade do capital, principalmente, quando essa 
informação incorporou as Tecnologias de Informação e de Comunicação e passou a fazer cada vez mais parte do cotidiano das sociedades na contemporaneidade.

A informação tornou-se midiatizada e passou a ser uma forma particular do espetáculo, constituindo o modelo atual da vida dominante na sociedade (DEBORD, 1997, p. 14). A importância desses novos mecanismos produzidos pelas diversas áreas de conhecimentos, principalmente da informática, fez com que a sociedade passasse a ter novas configurações, o que modificou o ser e o estar dos indivíduos no mundo. Esses saltos tecnológicos, na contemporaneidade, provocaram mudanças tão profundas na sociedade que, a cada dia, passamos a produzir cada vez mais informações e, no final, muitas vezes, passamos a não saber mais o que fazer com elas. Essa mesma sociedade passou e passa por profundas transformações que agrupou a si mesma um novo conceito que veio complementar o seu sentido, a saber, "da informação ${ }^{8 "}$.

A midiatização da informação propiciou novas formas de interação entre as pessoas, pois, independentemente do espaço e do tempo onde elas se encontram, as TICs propiciam a sua aproximação e interação, encurtando fronteiras espaços-temporais. Um dos grandes teóricos acerca da Sociedade da Informação é o espanhol Manuel Castells (2010, p. 51) o qual afirma que já é tradição em teorias do pós-industrialismo e do informacionalismo, começando com os trabalhos de Alain Touraine e Daniel Bell, situar a distinção entre préindustrialismo, industrialismo e informacionalismo (ou pós-industrialismo) num eixo diferente daquele em que se opõem capitalismo e estatismo (ou coletivismo, segundo Bell). Portanto, iniciamos nosso percurso analítico acerca da historicidade da Sociedade da Informação com Daniel Bell (1977), para quem a informação é a nova força motriz da sociedade contemporânea. Logo no prefácio de seu livro, Bell $(1977)^{9}$ afirma que não acredita numa trajetória determinística e que a sociedade pós-industrial não constitui uma "subestrutura" a instaurar modificações numa "superestrutura", além de afirmar que busca realizar um ensaio de previsão social. Para Bell (1977, p. 27), o conceito de sociedade pósindustrial está pautado em cinco dimensões ou componentes, quais sejam: 1) Econômica: a mudança para a sociedade pós-industrial ocasionará a passagem de uma economia da produção de bens para uma de serviços. 2) Distribuição ocupacional: uma preeminência da

\footnotetext{
${ }^{8}$ O conceito "Sociedade da Informação" pode ser considerado relativamente novo, pois data dos anos de 1970 , com Porat (1977), e sua oficialização em nível mundial deu-se em 1995, numa conferência do G7 consagrada a esse tema.

${ }^{9}$ Daniel Bell apresentou o conceito de sociedade pós-industrial durante um debate público sobre tecnologia e mudança social, realizado em Boston no ano de 1962, num longo comunicado. Para Bell, a sociedade pósindustrial seria desprovida de ideologia. Ele constrói o tipo ideal de uma sociedade e, para desenvolver seu tema, joga a teoria da burocracia de Max Weber contra a teoria das classes de Marx.
} 
classe profissional e técnica. 3) Princípio axial: a centralidade do conhecimento teórico atuará como fonte de inovação e de formulação política para a sociedade. 4) A orientação futura que será realizada pelo controle da tecnologia e da distribuição tecnológica. 5) Mudança na forma da tomada de decisões, uma vez que será criada uma nova "tecnologia intelectual".

Podemos perceber, pelos escritos de Daniel Bell que, como as Tecnologias de Informação e de Comunicação estavam cada vez mais presentes na sociedade, o referido autor, imaginou que, num futuro, as máquinas passariam a agir como seres humanos- como máquinas pensantes, conforme expressões de Barbrook (2009) e poderiam até mesmo substituí-los em seus postos de trabalho. Todavia, para o autor, isso soava como uma benesse da tecnologia para os humanos, pois, em vez de gastar horas nos postos de trabalho, a partir da concretização desse evento, os homens ocupariam mais o seu tempo em lazeres e desfrutariam das dádivas que as máquinas trariam para nós, portanto:

uma sociedade pós-industrial tem como base os serviços. Assim sendo, trata-se de um jogo entre pessoas. O que conta não é a força muscular, ou a energia, e sim a informação. A personalidade central é a do profissional, preparado por sua educação e por seu treinamento para fornecer os tipos de habilidades que vão sendo cada vez mais exigidos numa sociedade pós-industrial (BELL, 1977, p. 148).

Para o autor em lide, a sociedade pós-industrial teve início com o fim da Segunda Guerra Mundial, momento em que houve várias transformações no tempo e na configuração social. Para que uma sociedade seja baseada no setor de serviços, e no conhecimento teórico de seus trabalhadores, é necessário que se invista em educação, em capacitação profissional e o aumento das exigências técnicas e das habilidades profissionais faz da educação e do acesso à instrução superior a condição para o ingresso na própria sociedade pós-industrial (BELL, 1977). Na mesma linha de pensamento de Daniel Bell encontramos Masuda (1982) que, no livro A Sociedade da Informação como sociedade pós-industrial ${ }^{10}$, afirma que a sociedade está vivendo um período de transformação de uma sociedade industrial para uma Sociedade da Informação, também denominada de pós-industrial, uma vez que essa mesma sociedade provocará o aparecimento de novos conhecimentos, mercados e, consequentemente, novos profissionais e trabalhos. Este fato está em consonância com os ideários da pós-modernidade,

\footnotetext{
${ }^{10}$ Em 1913, o indiano Ananda K. Coomaraswamy, formado na Inglaterra, forja o qualificativo "pós-industrial". Em 1917, o termo pós-industrial é retomado pelo militante da Socialist Guild, o inglês Arthur J. Penty, admirador do utopista William Morris, crítico mordaz da fé na máquina. O neologismo ressurgirá nos anos 1960, em um contexto ideológico totalmente diferente. Sobre a Sociedade da Informação, buscar Mattelart (2006).
} 
uma vez que esta propõe e incentiva a criação de disciplinas e subdisciplinas totalmente novas, dentre elas, a biotecnologia, a nanotecnologia, tecnologia das mídias, etc.

Como seria, então, construída a Sociedade da Informação? Seria totalmente diferente da sociedade industrial, pois a força motriz da formação e do desenvolvimento dessa sociedade será a produção de valores informacionais e o que determinará a sua natureza fundamental será a tecnologia de telecomunicações e informática. Isso ocorreria de forma natural, como já ocorrera outrora, por exemplo, das sociedades agrícolas, para a industrial e, agora, da industrial para a pós-industrial, ou da informação. Na sociedade industrial, a tecnologia que fez a sociedade passar da agrícola para a industrial foi a máquina a vapor; na Sociedade da Informação essa tecnologia é o computador, que substituirá e amplificará o trabalho mental do homem. Na sociedade industrial foi a energia motora que aumentou a produção; na Sociedade da Informação, a revolução da informação expandirá o poder produtivo da informação e possibilitará a produção automatizada em massa de informação, tecnologia e conhecimentos cognitivos (MASUDA, 1982).

Podemos observar que Masuda (1982) afirma que as pessoas terão mais tempo livre para lazer, estudo e transformar a sociedade. Todavia, após mais de trinta anos da publicação do livro do autor em pauta, podemos perceber que as pessoas estão cada vez mais sem tempo livre. Basta olharmos ao nosso redor que podemos perceber os indivíduos correndo de um lado para outro e sempre com o discurso de que não tem tempo para nada. Conforme já afirmamos anteriormente, mesmo no atual momento em que estamos vivenciando o desenvolvimento do que Masuda (1982) delineou como Sociedade da Informação, e que sua principal característica seria um maior tempo livre, ainda persiste a alienação do tempo vivenciado pelas pessoas, a saber, um tempo não-vivido, nãoexperienciado, ou seja, um não-tempo,conforme ideias de Augé (1994), Marx (2003) e Chauí e Matos (2010).

Numa tentativa previsionista, Masuda (1982, p. 60) afirma que a constituição da sociedade da criação do conhecimento em massa, ou seja, o estágio mais avançado da era da informação, estará realizada na Terra lá pela metade do século XXI. O sistema educacional também será transformado na Sociedade da Informação, sendo a primeira transformação liberar a educação das escolas formais. A segunda será a introdução de um tipo de educação pessoal, adequado às habilidades de cada indivíduo, substituindo o tradicional sistema uniforme de educação coletiva por um sistema determinado pela habilidade e escolha individual. Em terceiro lugar, o sistema de autoensino tornar-se-á a principal forma de educação. Quando se introduz um sistema de autoaprendizado, os professores passam a agir 
como consultores ou conselheiros. A quarta mudança será a educação criadora de conhecimento. A quinta mudança vai significar educação por toda a vida. Isso será necessário para permitir que as pessoas possam se adaptar às mudanças da Sociedade da Informação.

Na Sociedade da Informação, o sistema econômico será baseado numa economia centrada na informação e a própria estrutura industrial será baseada na informação, alterando algumas de suas configurações. Uma das configurações que será alterada será o aparecimento das indústrias relacionadas com a informação, que se desenvolverão a tal ponto que serão classificadas no novo setor quaternário da economia, para diferenciá-la do setor de serviços.

Podemos perceber até aqui, com a apresentação do pensamento de Bell (1977) e Masuda (1982), que eles fazem previsões acerca de como seria a Sociedade da Informação e esboçam um plano futurístico de como a sociedade será transformada a partir dos avanços tecnológicos que a mesma vai alcançando. A informatização da sociedade permeará, conforme o pensamento dos referidos autores, todos os aspectos da vida humana em sociedade, perpassando pelos afazeres do dia-a-dia, operando até mesmo mudanças nos campos do mercado de trabalho, da saúde e da educação. Os dois autores estabeleceram tipos ideais a fim de oferecer um recurso analítico, baseado em conceitos de como seria a sociedade pós-industrial, ou da informação. Ambos afirmam que a sociedade passaria de um estágio baseado no setor industrial da economia, para o setor de serviços. A tecnologia passaria a fazer para os humanos o trabalho pesado que eles viessem fazendo, principalmente, no âmbito das indústrias, portanto, sobraria mais tempo livre para o trabalhador. Todavia, eles discordavam em um ponto: enquanto para Daniel Bell a informação faria parte do setor terciário da economia, ou seja, o de serviços, para Yoneji Masuda, ela faria parte do setor quaternário, a fim de diferenciá-la do setor de serviços, ou seja, a informação reorganizaria o setor econômico da sociedade alterando sua classificação em setor primário, secundário e terciário, fazendo surgir mais um setor, o quaternário, que seria o informacional.

Outra questão que nos colocamos acerca dos autores em lide é que, em nenhum momento, encontramos nessas duas obras, preocupações com a significação da gama de informações que seriam disponibilizadas para os indivíduos. O que encontramos é que os autores tratam da disponibilização de informações conforme a teoria de Shannon e Weaver, como transmissão de sinais, mas sem uma maior preocupação com a significação, com o conhecimento que seria, e se seria, atingido pelo sujeito.

As formulações de Bell e Masuda são corroboradas nos tempos hodiernos no que diz respeito à desterritorialização do mercado de trabalho e dos processos educacionais. Todavia, podemos perceber que, muito daquilo que Bell e Masuda idealizaram, concretizou- 
se em partes, pois, realmente, há a emergência, desde os anos de 1990, de um novo grupo de trabalhadores do setor de telecomunicações, decorrentes de uma sociedade cada vez mais informatizada, os quais são denominados por Antunes e Braga (2009) de cibertariado ou de infoproletários; todavia, o trabalhador não tem esse tempo livre idealizado pelos autores suprarreferidos, muito menos, melhores condições de trabalho, portanto:

\begin{abstract}
Infoproletários sustenta que, ao contrário daquilo que é, com frequência, advogado pelas teses da 'sociedade pós-industrial', o trabalho no setor de telemarketing é rigidamente condicionado pelas características desse processo de reprodução contraditória. Articula tecnologias do século XXI com condições de trabalho do século XIX, mescla estratégias de intensa e brutal emulação do teleoperador, ao modo da flexibilidade toyotizada, com técnicas gerenciais tayloristas de controle sobre o trabalhador; associa o serviço em grupo com a individualização das relações trabalhistas, estimula a cooperação ao mesmo tempo em que fortalece a concorrência entre os teleoperadores, dentre tantas outras alterações, ampliando as formas mais complexificadas de estranhamento e alienação contemporânea do trabalho (ANTUNES; BRAGA, 2009, p. 10).
\end{abstract}

Na contemporaneidade, o que ocorre é que o poder está a cada dia mais líquido, utilizando expressões do sociólogo Zygmunt Bauman (2001, 2004, 2005), o que passa a desarticular a mobilização dos trabalhadores. Com a flexibilidade proporcionada pelas Tecnologias de Informação e de Comunicação, a própria noção de centro parece não mais existir, uma vez que as empresas operam "em rede", conforme expressões de Castells (2010). Todavia, conforme Castells (2010), a rede não tem um centro do poder e, se num primeiro momento, os operários das fábricas sabiam quem era o seu patrão, se o poder estava definido de onde ele era irradiado, na contemporaneidade, o trabalhador não sabe mais quem é seu patrão e isso colabora com a desarticulação da classe trabalhadora e com a manutenção do poder por parte de quem já o detém. Ou seja, o que parece ocorrer não é uma autonomização do trabalhador em relação ao seu local de trabalho, mas sim, uma espécie de vigilância "panóptica”, conforme expressões de Foucault (1999) do trabalhador em relação a si mesmo. O trabalhador passou a se vigiar no seu local de trabalho, que, por vezes, é sua própria casa. $\mathrm{O}$ que acontece não é que o trabalhador tenha mais tempo livre, conforme as formulações de Bell (1977) e de Masuda (1982), mas sim, que sua casa também é um local de trabalho e as formas de dominação do trabalhador se tornam cada vez mais sutis e abstratas.

Com a informatização dos locais de trabalho, há uma maior possibilidade da fragmentação dos coletivos de trabalhadores, devido, principalmente, à inviabilização das formas coletivas de ação social na mundialização capitalista. O trabalhador está pari passu saindo de seus locais de trabalho para se tornarem trabalhadores autônomos, tendo como ferramentas de trabalho apenas um computador e informações que ele possui; todavia, parece 
que as jornadas laborais aumentaram, uma vez que esse tipo de trabalhador está desvinculado e precisa produzir, para suprir suas necessidades, e acaba por não ter jornadas fixas. Isso acontece tanto com o trabalhador autônomo, quanto com aqueles que estão incorporados, ou seja, inseridos em alguma instituição de trabalho. Antunes e Braga (2009, p. 70) exemplificam as relações infoproletárias nas centrais de teleatendimento:

Do ponto de vista das características gerais do trabalho dos operadores ocupados em Centrais de Tele Atendimento é possível realçar que: a) as operações de teleatividades são realizadas 24 horas por dia, 7 dias por semana- consequentemente, as CTA's exigem uma grande disponibilidade dos trabalhadores; b) na medida em que essa disponibilidade encontra-se associada a condições difíceis de trabalho, temos como resultado uma forte intermitência; c) o trabalho submete-se agudamente ao fluxo informacional: ao final de uma chamada, sucede a seguinte, seja automaticamente (em intervalos de 0 a 20 segundos, dependendo do tipo de operação), seja manualmente, após um máximo de dois ou três sonidos.

O que podemos perceber é que as previsões de Bell (1977) e de Masuda (1982) se efetivaram apenas em parte, pois parece que o trabalhador, cada vez mais, teve de se submeter aos processos de trabalho alienante da Sociedade da Informação. Seria importante e necessário pesquisas futuras acerca dos processos de trabalhos dos profissionais de nível superior denominados "profissionais da informação", dentre os quais bibliotecários, museólogos, arquivistas, etc., que contemplassem categorias tais como os processos de infoproletarização dos profissionais da informação. Será que há empresas que determinam hora/livro catalogado? Hora/jornal indexado? Como são os processos de trabalho dos profissionais da informação hodiernamente?

Retomamos nosso diálogo acerca da Sociedade da Informação, mas noutra perspectiva com Armand Mattellart (2006) ${ }^{11}$, Richard Barbrook (2009) e Manuel Castells (2010), os quais são autores mais contemporâneos que os outrora analisados. Numa linha diferente da de Bell (1977) e de Masuda (1982), os autores em lide buscam analisar a constituição da Sociedade da Informação numa perspectiva histórica e não apenas de planejamento societal. Enquanto os autores que trabalhamos até aqui estavam mais preocupados em planejar a Sociedade da Informação e em prever como seria a sua configuração ao ser implementada, a tríade supracitada atua numa perspectiva contrária, ou seja, eles buscam, por meio da reconstituição histórica e, outrossim, relacionando aos fatos históricos que ocorriam à época, analisar a sociedade que está em emergência, sem, contudo, adentrar numa perspectiva de previsão social. Os referidos autores abordam a Sociedade da

\footnotetext{
${ }^{11}$ Sociólogo belga, radicado na França, especializado no estudo da comunicação internacional.
} 
Informação de forma contrária aos discursos apologéticos de Bell, Masuda e outros, que a definem de forma evolutiva e inevitável.

Para Mattelart (2006), embora a gênese da referida sociedade possa ser vinculada ao advento das TICs, as raízes desta sociedade estão no século XVII e, para comprovar esta tese, ele articula diversos fatos históricos e vários autores com vistas a corroborar a ideia de que a noção de uma Sociedade da Informação é um discurso construído que realça a crença no poder das tecnologias de transformar a realidade. Sua análise é uma tentativa de buscar respostas para indagações como: qual a relação do desejo de uma língua universal, da biblioteca universal e a Sociedade da Informação? Qual a relação da tese do fim das ideologias e a invenção da fonte de informação?

Portanto, se a gênese da Sociedade da Informação pode ser vinculada às Tecnologias de Informação e de Comunicação emergentes, então a década de sua gênese pode ser vinculada mais precisamente ao espaço-tempo dos Estados Unidos em fevereiro de 1946, quando foi criado o Electrical Numerical Integrator and Computer (ENIAC). Este primeiro computador digital-eletrônico de grande escala, é considerado o primeiro ícone midiático da era da computação- tratava-se de uma máquina de calcular tabelas para melhorar a precisão da artilharia e determinar o poder explosivo de bombas nucleares. Ao começar a fazer mainframes no final dos anos de 1940, a estratégia corporativa da International Business Machines (IBM) estava focada em ganhar encomendas militares. Em 1952, a dependência da IBM frente aos militares estadunidenses era simbolizada pelo nome patriótico dado ao seu computador 701: a Calculadora de Defesa. Os militares estadunidenses e seus fabricantes de armamentos eram os únicos compradores desse mainframe. Em 1953, a IBM fechou um contrato para construir computadores para o Comando de Defesa Aérea: o centro de controle para combater uma guerra nuclear com a Rússia. Graças à generosidade do contribuinte estadunidense, a IBM tornou-se a líder tecnológica da indústria de computação global (BARBROOK, 2009, p. 69).

Em 1951, o Univac I, o primeiro computador de uso não militar, é entregue ao US Bureau of the Census. Em 1957, os russos lançaram o satélite Sputnik e, a partir desse momento, os Estados Unidos e a Rússia passaram a competir a fim de comprovar a sua supremacia tecnológica. Foi nesse período que se passou a acreditar que "visitar outros planetas no futuro seria tão barato e fácil como viajar a outras cidades no presente. Dentro de algumas décadas, cada estadunidense seria um astronauta" (BARBROOK, 2009, p. 45). No ano seguinte, ocorre algo crucial, já que no ano anterior a União Soviética desafiara a América ao lançar o satélite Sputnik, abrindo assim outra frente da Guerra Fria, a luta pela 
conquista espacial; o Pentágono cria uma agência de coordenação de contratos de pesquisa federal: Defense Advanced Research Projects Agency (DARPA). Dez anos depois, a fim de facilitar os intercâmbios entre as diferentes equipes contratantes, essa agência inaugura a rede Arpanet, ancestral da Internet.

Para muitas corporações, o método mais eficaz de comprovar sua modernidade tecnológica foi exibir um computador. Ironicamente, embora desempenhassem um papel proeminente na cobertura da Feira Mundial de Nova Iorque de 1964, nos meios de comunicação, quase todos esses caros computadores mainframes eram artifícios de alta tecnologia. Passar-se-iam quase duas décadas até que os primeiros computadores pessoais aparecessem nos escritórios e lares (BARBROOK, 2009, p. 47).

Nos anos de 1960, a tese do fim da ideologia, tão propagada pelos ideólogos do pós-modernismo e do neoliberalismo, é um ponto de união de muitos cientistas políticos e sociólogos, principalmente, americanos. O tema foi até mesmo ratificado internacionalmente na reunião organizada, em setembro de 1955, em Milão, sobre o tema $O$ futuro da liberdade, pelo Congresso em Favor da Liberdade da Cultura, organismo fundado em Berlim em 1950. Entre os 150 participantes dessa reunião mundial de políticos e intelectuais em torno da "sociedade livre" há personagens tão diversos quanto os socialistas ingleses Hugh Gaitskell e Richard Crossman, Arthur Shlesinger Jr., futuro conselheiro do presidente J. F. Kennedy, o economista Friedrich A. Von Hayek, que logo após a guerra fundara a Sociedade de MontPèlerin, central de uma internacional ultraliberal que escolheu como alvo as teses keynesianas e marxistas; além do professor francês Raymond Aron, que acabara de publicar L'Opium des intellectuels, bem como Daniel Bell e outros (MATTELART, 2006, p. 79-80).

No período da Guerra Fria, os militares estadunidenses e a CIA- a nova agência de inteligência montada para combater a Guerra Fria- disponibilizava empregos acadêmicos e financiamento de pesquisas para socialistas arrependidos. A tarefa primária desses intelectuais estadunidenses era continuar a demolição teórica do marxismo. Assim como produzir cibernética sem Wiener, inventar o marxismo sem Marx tornara-se agora uma prioridade ideológica. Pelo início dos anos de 1950, assim como nas ciências naturais, as equipes multidisciplinares tornaram-se a pesquisa intelectual de ponta dentro das ciências sociais nas universidades estadunidenses. Apesar de pesquisas quantitativas e estudos empíricos poderem desafiar pequenos detalhes nos escritos de Marx, à ciência social estadunidense faltava uma substituição de sua grande narrativa que explicasse a ascensão do capitalismo. Em 1960, Walt Rostow- um proeminente acadêmico do centro de pesquisa Center for International Studies (CENIS) financiado pela Central Intelligence Agency (CIA) no Massachussets Institute of 
Technology (MIT)- publicou o livro que finalmente proveu o império estadunidense com sua própria e distinta grande narrativa da modernidade: Etapas do desenvolvimento econômico: um manifesto não-comunista (BARBROOK, 2009, p. 138-139; 142; 145).

Na década de 1960, quando Licklider era diretor da ARPA ele foi o mentor da comunidade virtual formadora da Internet e seu principal objetivo com uma comunicação mediada por computador era facilitar os métodos de trabalho idiossincráticos da comunidade científica. Para ele, compartilhar conhecimento era muito mais produtivo do que comercializar informação. Como as cooperativas descritas por Marx em O Capital, volume 3, os desenvolvedores da Arpanet foram encorajados a se comportarem como comunidades autogovernantes. As pessoas que construíram a Internet eram aquelas que a coordenavam. Em uma reviravolta irônica, no auge da Guerra Fria, os militares estadunidenses financiavam a invenção do comunismo soviético (BARBROOK, 2009, p. 230-232).

Aqui encontramos uma das principais contradições do capital: Marx (2004), afirmara nos Grundrisse (1857-1858), que o "capital é uma contradição em processo", então vale assinalar o paradoxo, expresso em questões: como que em plena Guerra Fria, momento em que o capitalismo e socialismo rivalizavam entre si, o lado capitalista (representado pelos Estados Unidos) passa a financiar pesquisas que propunham o compartilhamento de conhecimentos e formava comunidades autogovernadas? Como que, no momento em que o capitalismo luta pela sua hegemonia na Terra, ele mesmo se contradiz?

Voltando aos desenvolvimentos tecnológicos do pós-guerra em sua segunda versão, temos a criação da Internet, a qual também contribuiu para a história da Sociedade da Informação. Portanto, foi na Conferência da Sociedade Cibernética Estadunidense, em 1964, que Ford argumentou que a corrida para inventar a Internet era uma competição tanto tecnológica, quanto ideológica. O dinheiro da ARPA direcionou a pesquisa da Ciência da Computação para atingir esse objetivo técnico e político. A Comissão Bell focou a atenção dos departamentos de Ciências Sociais sobre a transição para a Sociedade da Informação (BARBROOK, 2009, p. 236).

Entre 1948 e 1991, o equilíbrio da Guerra Fria sustentou a dominação dos Estados Unidos no sistema mundial. Assim que o seu oponente russo se dobrou, os Estados Unidos foram proclamados como os vencedores desse grande jogo. O capitalismo derrotara o comunismo. Era, pois, nesse mesmo período, que a pós-modernidade e o neoliberalismo estavam se firmando. No momento em que o conceito de pós-modernismo foi inicialmente proposto, em meados dos anos de 1970, muitos de seus pais fundadores argumentaram que a 
disseminação das Tecnologias de Informação e de Comunicação seria a responsável pela emergência desse novo paradigma social.

A liberalização do conjunto do sistema de comunicação dos Estados Unidos sob a presidência de Ronald Reagan coexiste com o retorno, em uma posição forte, do departamento de defesa na inovação tecnológica, por meio da Strategic Defense Iniciative (SDI), também chamada de "guerra nas estrelas". Lançado no dia 23 de março de 1983, esse projeto visava à construção de um sistema antimíssil, o qual seria baseado em satélites, capaz de interceptar o ataque inimigo em pleno ar. Deixado de lado, ele ficou para ser relançado em 2001, pelo presidente George W. Bush. Os japoneses acabavam de anunciar seu projeto de computador de quinta geração. Os americanos respondiam fazendo a Defense Advanced Research Projects Agency (DARPA) assumir o papel federativo desempenhado no Japão pelo superministério da indústria (MATTELLART, 2006, p. 118).

Numa outra vertente, um autor que vem nos ajudar a pensar o desenvolvimento da Sociedade da Informação é o sociólogo espanhol Manuel Castells (2010) o qual busca compreender como as Tecnologias de Informação e de Comunicação estão realizando uma nova formatação na sociedade, ocasionando aquilo que o autor denomina de Sociedade em Rede. O autor afirma não pretender discutir as teorias existentes sobre o pós-industrialismo ou sobre a Sociedade da Informação, uma vez que já existem muitas apresentações abrangentes e equilibradas dessas teorias e também não visa a contribuir com a teoria pós-moderna, uma vez que já se encontra satisfeito com a crítica elaborada por Harvey sobre os fundamentos sociais e ideológicos da "pós-modernidade" e com a análise sociológica das teorias pós-modernas de Scott Lash. Castells reitera dever muito de suas ideias a vários autores, dentre os quais, Alain Touraine, Daniel Bell e Nicolas Poulantzas (CASTELLS, 2010, p. 60-61).

Manuel Castells (2010) assinala a emergência de uma nova forma de sociedade: a sociedade em rede, ou seja, uma sociedade em que os âmbitos político, econômico, social e cultural efetivam-se num espaço de fluxo, e fluxos globais, por meio das redes. Essa nova sociedade é marcada pela cultura do virtual, construída pelas mídias e pelas Tecnologias de Informação e de Comunicação. Em sua análise acerca da "sociedade em rede" afirma que a perspectiva teórica que fundamenta sua análise é o seguinte postulado: as sociedades são organizadas em processos estruturados por relações historicamente determinadas de produção, experiência e poder.

Conforme o pensamento do autor supracitado o momento contemporâneo é um dos raros momentos de intervalos na história (o que, na realidade vai ao encontro das teses de Sousa Santos (1987)), pois estamos diante de uma transformação na nossa cultura material 
por meio de um novo paradigma tecnológico que se organiza em torno das TICs. Desta feita, para Castells (2010, p. 67-68), “as tecnologias referem-se ao uso de conhecimentos científicos para especificar as vias de se fazerem as coisas de uma maneira reproduzível e inclui dentre as tecnologias de informação a engenharia genética e seu crescente conjunto de desenvolvimentos e aplicações". Castells (2010) trata desse período de desenvolvimento da engenharia genética, da nanotecnologia, da biotecnologia como um evento histórico da mesma importância da Revolução Industrial do século XVIII, daí Almeida, P. (2005) afirmar que essa era se trata da quarta revolução industrial.

A revolução das tecnologias ${ }^{12}$ em sua forma mais expressiva nas Tecnologias de Informação e de Comunicação vem remodelando a base material da sociedade contemporânea num ritmo veloz, e o próprio sistema do capital foi reformulado, uma vez que se caracteriza por uma maior flexibilidade de gerenciamento. No novo modo de produção informacional de desenvolvimento, a fonte de produtividade acha-se na tecnologia de geração de conhecimentos, de processamento da informação e de comunicação de símbolos (CASTELLS, 2010, p. 53). A sociedade em rede é uma nova estrutura social que se manifesta das mais variadas formas conforme a diversidade de culturas e instituições. Para o autor em pauta, a tecnologia não determina a sociedade, uma vez que a própria sociedade é tecnologia, já que o curso da sociedade escreve as transformações tecnológicas. A revolução das TICs difundiu pela cultura mais significativa da sociedade o espírito libertário dos movimentos dos anos 60 .

Conforme afirmou Castells (2010) a nova infraestrutura social é a tecnologia, a qual vem provocando transformações tanto no mundo do trabalho, quanto no mundo da vida. Em relação ao mundo do trabalho vemos o surgimento de um novo modelo de trabalhador: o cibertariado, ou conforme expressão de Antunes e Braga (2009) “infoproletários”. Além das transformações na base material da sociedade, a política também está sendo modificada na Sociedade da Informação. Vemos, por exemplo, no Brasil, que a partir dos anos de 1980, estamos vivenciando um processo de redemocratização e experienciando a inserção do País na nova ordem mundial. Todavia, percebemos a grande disparidade da modernização brasileira quando, por exemplo, visualizamos que, enquanto há áreas do País que vivenciam a sua entrada na Sociedade da Informação, utilizando as benesses e os malefícios das TICs, há

\footnotetext{
${ }^{12}$ Para Castells (2010, p. 76) foi durante a Segunda Guerra Mundial e, no período seguinte, que se deram as principais descobertas tecnológicas: o primeiro computador programável e o transistor, fonte da microeletrônica: o verdadeiro cerne da revolução da tecnologia da informação no século XX. Porém, para Castells, só na década de 1970, as novas tecnologias da informação difundiram-se amplamente, acelerando seu desenvolvimento sinérgico e convergindo em um novo paradigma.
} 
ainda áreas que não possuem sistema de esgoto, nem energia elétrica. E esses são aspectos ambivalentes do cenário da Sociedade da Informação que têm que ser levados em conta ${ }^{13}$.

Nesse mesmo aspecto da ambivalência temos as tecnologias digitais constitutivas da Sociedade da Informação, pois se por um lado, elas possibilitam a emancipação; por outro, elas poderão ocasionar novas formas de dominação. Portanto, as tecnologias não podem ser deixadas de lado, mas sim, podem ser apropriadas, utilizadas pelos sujeitos e como um espaço para o exercício da cidadania e da democracia. Castells (2003, p. 276) afirma que "a maior parte dos movimentos sociais e políticos do mundo, de todas as tendências, usa a Internet como forma privilegiada de ação e organização". Portanto, podemos perceber que a rede funciona como mecanismo, como meio de transformação cultural da sociedade. Por exemplo, por meio das tecnologias os atores sociais passam a atuar de forma mais efetiva devido à mobilidade que a Internet propicia e, dessa forma, a Internet se torna um espaço privilegiado de mobilização, de atuação política dos homens, que transformam a sua cultura, as formas como interagem uns com os outros e as próprias formas de conhecer. A Internet pode ser utilizada como um meio de desafiar os poderes instituídos, de denunciar a opressão e promover lutas, mobilizando atores individuais e coletivos.

Mesmo diante das possibilidades de agregação social propiciadas pelas TICs, não podemos ser ingênuos a ponto de pensar que elas são usadas apenas como mecanismo de atuação política. Parece que à proporção que novas formas de mobilização social são realizadas nesse ambiente, paradoxalmente, novas versões de criminalidade e de banditismo são realizadas em rede. Não nos esqueçamos de que senhas são descriptografadas, cartões são clonados, dentre outras formas de banditismo em/na rede.

Em relação às transformações no campo das ciências, podemos perceber que as tecnologias passaram até mesmo a transformar áreas de saberes, muitas vezes chegando ao ponto de fazer surgir novas áreas de conhecimentos, dentre as quais a nanotecnologia e a biotecnologia, que, em conjunto com as TICs, alteraram as formas de ser e estar das sociedades na contemporaneidade, tanto no que concerne ao mundo da vida, do trabalho, bem como da educação. Este fato vem a corroborar com os escritos de Masuda (1982) quando o mesmo afirmara que a Sociedade da Informação virá provocar o surgimento de novos

\footnotetext{
${ }^{13}$ Para utilizar as expressões de Bauman (1999) a Sociedade da Informação possui seus aspectos ambivalentes, pois enquanto a sociedade se globaliza ainda mais, principalmente, com as convergências digitais, as desigualdades se acentuam e causam a discriminação linguística, a marginalização territorial e a subestimação de saberes tradicionais. Para superar esta contradição, García Canclini (2007) propõe a interculturalidade a fỉm de que se dê continuidade aos pertencimentos étnicos, grupais e nacionais.
} 
conhecimentos, mercados e, consequentemente, novos profissionais e trabalhos, o que vem ocorrendo com as inovações e avanços propiciados pelas nano e biotecnologias.

As tecnologias, ao entrarem no século XXI, saíram da macroescala e passaram para escalas micro e nano e, diante deste cenário, buscamos compreender em que medida o ciberespaço e suas comunidades virtuais, baseados em nanobiotecnologias, nos ajudam a pensar no caráter revolucionário da tecnologia com respeito à sociedade, e, também, sobre o peso das inovações sociais, tecnológicas, políticas e econômicas em nossa vida cotidiana. Como essas inovações nos fazem pensar, também, no contexto que estamos vivenciando? Como as tecnologias podem ser utilizadas para a prática do exercício do poder? Portanto, não podemos esquecer-nos do casamento bem sucedido entre globalização e neoliberalismo, cujo maior exemplo desta realidade pode ser encontrado na forma como os meios de comunicação, consorciados com as TICs, há muito vem contribuindo para a mediação e/ou aproximação dos povos e culturas. Mas, o que é neoliberalismo?

Antes de respondermos a esta indagação, e porque as etapas históricas são atravessadas por mentalidades que se fincam em determinada época e cultura, devido às peculiaridades sociais e, também, por causa das determinações pelas quais passam a sociedade, iniciaremos nossa discussão com a historicização do liberalismo realizada por Holanda (2001). Para o referido autor, a era moderna foi atravessada pelo liberalismo, que teve início no século XVI após a queda do sistema feudal ${ }^{14}$ e a instauração do regime burguês, ou capitalista. O capitalismo precisa de ideologias, de visões de mundo, de cosmovisões que lhe sirvam de sustentáculo para continuar a vigorar. No início desse sistema socioeconômico, ainda na era moderna, era o liberalismo; depois, com um acirramento cada vez mais acelerado e intenso das características modernas no seio societal, alguns autores passaram a denominar o período contemporâneo de pós-modernidade (dentre outras denominações) e sua base de sustentação econômica e ideológica de neoliberalismo.

Depois da crise de 1930, a reestruturação das formas de Estado e das relações internacionais depois da Segunda Guerra Mundial pretendia impedir um retorno às condições catastróficas que tanto ameaçaram o poder capitalista na referida crise. Desta feita, uma nova ordem mundial foi construída com os acordos de Breton Woods, juntamente com várias instituições, como a Organização das Nações Unidas (ONU), o Banco Mundial (BM), o Fundo Monetário Internacional (FMI) e o Banco Internacional de Compensações (uma

\footnotetext{
${ }^{14}$ A partir do século X, paulatinamente, as bases das instituições feudais começaram a ser minadas e o esboço de um novo padrão econômico começou a se desenvolver e, com ele, emergiu uma nova mentalidade. Esse novo padrão econômico era a empresa capitalista (HOLANDA, 2001, p. 14).
} 
espécie de Banco Central dos bancos centrais e batiza também o acordo que trata da normatização dos acordos bancários como Basiléia, também devido ao fato de esta cidade sediar este banco), com o objetivo de ajudar a estabilizar as relações internacionais (HARVEY, 2008, p. 20).

O neoliberalismo se diferencia do liberalismo clássico do século XVIII no tratamento do problema da igualdade. O liberalismo clássico, baseado na Lei Natural e no Direito Natural, exigia a igualdade nos direitos civis para todos, porque pressupunha serem iguais todos os homens. Para os neoliberais, os homens não são iguais, pois mesmo entre irmãos há diferença nos atributos físicos e mentais (HOLANDA, 2001, p. 70).

Como o neoliberalismo adentrou na arena política? Em primeiro lugar, foi gerado suficiente consentimento popular para legitimar o neoliberalismo, ou seja, fortes influências ideológicas circularam nas corporações, nos meios de comunicação e nas numerosas instituições que constituem a sociedade civil- universidades, escolas, igrejas e associações profissionais. E é nesse nível- a experiência da vida cotidiana sob o capitalismo na década de 1970- que começamos a ver como o neoliberalismo penetrou nas compreensões do "senso comum" (HARVEY, 2008, p. 50). Para os teóricos neoliberais, a desigualdade era um valor positivo e afirmavam que as sociedades ocidentais precisavam dela. Todavia, essa ideia permaneceu na teoria por mais ou menos vinte anos, pois, foi apenas na crise do modelo econômico pós-guerra, em 1973, que as ideias neoliberais passaram a ganhar terreno político. Em seguida, temos a ascensão dos governos Thatcher ${ }^{15}$, na Inglaterra (1979); de Reagan, nos Estados Unidos (1980) e Helmut Khol, na Alemanha (1982), na virada dos anos 70 para os 80, cujas ideias liberais foram retomadas e adaptadas aos tempos modernos sob o rótulo de “neoliberalismo". Posteriormente, em vários outros países, os partidos de direita, vinculados à concepção neoliberal, assumiram o poder a partir da década de 1980, inclusive na América Latina.

Todo movimento político que considera sacrossantas as liberdades individuais correm o risco de ser incorporado sob o escopo neoliberal. A retórica neoliberal tem sua ênfase fundacional nas liberdades individuais, no poder de fragmentar o libertarianismo, na política da identidade, no multiculturalismo e até no consumismo narcisista, advindo das forças sociais. O neoliberalismo era bem adequado a essa tarefa ideológica, precisando, porém, da sustentação de uma estratégia prática, que enfatizasse a liberdade de escolha do

\footnotetext{
${ }^{15}$ Margaret Thatcher já tinha sido eleita primeira-ministra da Grã-Bretanha, em maio de 1979, com a tarefa de restringir o poder dos sindicatos e levar ao fim uma destruidora estagnação inflacionária que envolvera o País na década precedente. Com a eleição de Thatcher, a Inglaterra foi o primeiro regime de capitalismo avançado publicamente empenhado a pôr em prática o programa neoliberal (HARVEY, 2008, p. 11).
} 
consumidor, não só quanto a produtos particulares, mas também, quanto a estilos de vida, formas de expressão e uma ampla gama de práticas culturais. No tocante a isso, ele se mostrou mais que compatível com o impulso cultural chamado "pós-modernismo", que, política e economicamente, agora podia surgir como dominante tanto cultural quanto intelectualmente. As virtuosas reivindicações de especialização flexível nos processos de trabalho e de flexibilização dos contratos de trabalho puderam tornar-se partes da retórica neoliberal. Uma maior liberdade em geral e a liberdade de ação no mercado de trabalho podem ser louvadas como uma virtude tanto para o capital como para o trabalho e, também nesse caso, não foi difícil integrar valores neoliberais ao "senso comum" de boa parte da força de trabalho (HARVEY, 2008, p. 63).

O que diferencia a modernidade liberal da pós-modernidade neoliberal não é apenas que, na primeira, a liberdade era intrínseca ao indivíduo, mas sim, o deslocamento ocorrido durante os últimos cinquenta anos, na noção e no lugar social do cultural; era o que, na realidade acontecia, quando o desenvolvimento da modernidade "ilustrada" caracterizava a cultura como um bem desejável para todos, que devia ser difundido amplamente, explicado e tornado acessível; em contraste com a concepção neoliberal, que a situa como um conjunto opcional de bens adquiríveis, aos quais se pode ou não ter acesso (GARCÍA CANCLINI, 2007, p. 51). Ou seja, para García Canclini (2007, p. 94) “o pensamento pós-moderno (não só o neoliberal, mas também, o que sustenta uma crítica social) destacou a mobilidade e a desterritorialização, o nomadismo e a flexibilidade de pertencimentos". É nesse sentido que afirmamos que a pós-modernidade e o neoliberalismo são duas faces de uma mesma moeda, ou seja, não há divergências ideológicas entre eles.

Em relação à sociedade brasileira, o neoliberalismo emerge também na década de 1980, no governo do presidente José Sarney (1985-1990), num momento em que a economia brasileira estava em processo de acomodamento. Já nos anos de 1990, o mercado brasileiro foi aberto irrestritamente ao mercado financeiro internacional, no governo de Fernando Collor de Mello (1990-1992), momento em que o País adentrou no processo de globalização econômica, lançando os produtos brasileiros à concorrência com os de procedência internacional. Este fato ocasionou o fechamento de empresas nacionais, diminuindo os postos de trabalho, e é devido a este fato que Jannuzzi e Mattos (2001, p. 116) denominam esse período de a década neoliberal, a qual se estendeu, também, aos governos dos presidentes Fernando Henrique Cardoso, em seus dois mandatos, sob a forma de privatização de empresas estatais e a aplicação de muitas das recomendações do Consenso de Washington, dentre elas, a abertura dos serviços públicos para a iniciativa privada; bem como aos mandatos do 
presidente Luís Inácio Lula da Silva, todavia, em uma nova versão. Ou seja, o modelo neoliberal de Lula promoveu pequenas mudanças na política social, econômica e educacional, iniciando uma política agressiva de exportação, centrada no agronegócio e unificou as bolsas e ajudas efêmeras que vinham sendo implementadas, desde o governo do presidente Sarney, em um único pacote chamado bolsa família, sendo concedidas sob a obrigatoriedade de as crianças estarem matriculadas nas escolas (BOITO JÚNIOR, 2005, p. 10).

Portanto, a partir dos efeitos sentidos pelos cidadãos nos diferentes governos neoliberais, e devido às mudanças no sistema educacional que esses governos vêm implementando até o presente momento (mesmo no governo da presidente Dilma Rousseff), que analisamos, no próximo capítulo, como o neoliberalismo vem impactando a educação e os currículos. 


\section{A FORMAÇÃO EM CIÊNCIA DA INFORMAÇÃo E A QUESTÃo DA MEDIAÇÃ̃o}

Neste capítulo abordaremos as teorias de currículo como forma de analisar a formação em Biblioteconomia e Ciência da Informação, buscando perceber também os conceitos da Mediação da Informação a fim de visualizar, a posteriori, como os conteúdos relativos à mediação estão inseridos e tratados no currículo de formação de bibliotecários.

\subsection{Teorias do Currículo}

Para discutirmos historicamente as várias teorias curriculares, é mister lembrar que a escola surge, historicamente, como uma instituição de mediação, especializada em atender à necessidade de levar a cabo determinados processos de transmissão cultural. A mediação é um processo de interconexão e vinculação entre as mensagens por um lado, e os significados e ações por outro. A escola, como instituição, mediatiza os valores sociais, culturais e informacionais da comunidade e as experiências planificadas para os estudantes. Assim, pois, os interesses externos filtram-se por meio das disposições institucionais (CORNBLETH, 1998 apud AMANTEA et al., 2006, p. 66). Podemos iniciar, portanto, da metáfora do currículo como uma pista que os alunos devem percorrer, a fim de alcançar seus objetivos.

Em nossas primeiras buscas acerca do conceito de currículo, encontramos que a sua etimologia é originária do latim curriculum e significa "pista de corrida". Entendido desta forma trata-se, portanto, da trajetória que o aluno deve percorrer em busca de subsídios para o seu desenvolvimento pessoal e profissional objetivando construir a sua identidade. $\mathrm{O}$ conceituado Oxford English Dictionary situa as raízes mais antigas do conceito de curriculum em 1633, na Universidade de Glasgow, cujo senso de disciplina, ou ordem estrutural, absorvido no currículo, precedeu não tanto de fontes clássicas, quanto das ideias de João Calvino (BURKE, 2003). O currículo representava para sua prática educacional, o que era a disciplina para a prática social calvinista, ou seja, um aparelho disciplinar, utilizando termos althusserianos. Portanto, Burke (2003, p. 83) afirma que "o currículo é uma metáfora do atletismo clássico, assim como o 'curso' era a pista onde os estudantes tinham que correr. Era uma ordem ou sistemas de 'disciplinas"'. A palavra foi empregada, pela primeira vez, num contexto acadêmico por Juan Luis Vives (1492-1540). 
Epistemologicamente, a história das teorias curriculares data do início do século XX, nos Estados Unidos, com Franklin Bobbitt e seus livros The Curriculum (1918) e How make the curriculum (1924), além de outros teóricos, dentre os quais W. W. Charters, Edward L. Thorndike, Ross L. Finney, Charles C. Peters e David Snedden. Importante destacar que esses pressupostos teóricos acerca do currículo, como campo de conhecimentos, logo no início, propunham que a escola fosse administrada tal qual uma empresa e, para tanto, tomasse como modelo a administração científica de Taylor.

Elencaremos, a seguir, algumas teorias curriculares, com base nos escritos de Tomaz Tadeu da Silva (2007) o qual, na perspectiva dos estudos culturais, classifica as teorias em tradicionais, críticas e pós-críticas. Mesmo seguindo as trilhas apontadas pelo autor, na medida em que formos apresentando as teorias acrescentaremos nossas próprias observações e interpretações.

O marco do estabelecimento do currículo como campo especializado de estudos é a publicação do livro The Curriculum, de Bobbitt, em 1918, nos Estados Unidos, País que, à época, reunia algumas características que permitiram o surgimento do campo de estudos sobre currículo, dentre as quais: a formação de uma burocracia estatal encarregada dos negócios ligados à educação; o estabelecimento da educação como um objeto próprio de estudo científico; a extensão da educação escolarizada em níveis cada vez mais altos da população; as preocupações com a manutenção de uma identidade nacional, como resultado das sucessivas ondas de imigração e o processo de crescente industrialização e urbanização (SILVA, 2007, p. 22).

Nesse contexto, a maior preocupação dos dirigentes escolares era acerca dos processos de racionalização, sistematização e controle da escola e do currículo. Ou seja, o propósito maior era planejar, cientificamente, as atividades pedagógicas e controlá-las de modo a evitar que o comportamento e o pensamento do aluno se desviassem de metas e padrões pré-definidos (MOREIRA; SILVA, 1999, p. 9). O que Bobbitt buscava responder era o seguinte questionamento: em termos sociais, quais devem ser as finalidades da educação: ajustar as crianças e os jovens à sociedade tal como ela existe ou prepará-los para transformála; a preparação para a economia ou a preparação para a democracia? O modelo de currículo de Bobbitt iria encontrar sua consolidação definitiva num livro de Ralph Tyler, publicado em 1949, intitulado Princípios Básicos de Currículo e Ensino, um programa elaborado para a disciplina Educação 360, na Universidade de Chicago, cujas ideias se tornaram mais conhecidas como os Princípios de Tyler. 
O paradigma estabelecido por Tyler iria dominar o campo do currículo nos Estados Unidos, com influência em diversos países, incluindo o Brasil, pelas próximas quatro décadas. Com o livro de Tyler, os estudos sobre currículo se tornam decididamente estabelecidos em torno da ideia de organização e desenvolvimento (SILVA, 2007, p. 25). O professor tradicional apresenta os conteúdos aos seus alunos como prontos e acabados. Apresenta os conteúdos de maneira fragmentada e o aluno é visto como um ser receptivo e passivo, ou seja, é o tipo de educação que Paulo Freire denominou de bancária. Portanto, as teorias tradicionais de currículo foram utilizadas até surgir outros movimentos que se apresentavam contra uma concepção técnica de currículo e só foram contestados nos Estados Unidos na década de 1970, com o chamado "movimento de reconceptualização" do currículo, tanto no Brasil, quanto nos Estados Unidos, principalmente, devido ao contexto sociohistórico que era de grandes agitações desde a década de 1960.

Atualmente, cada país reivindica a precedência desses movimentos de reconceitualizações curriculares para si. Para os Estados Unidos, a renovação da teorização curricular foi exclusividade do Movimento de Reconceitualização. Para a Inglaterra, foi da Nova Sociologia da Educação, um movimento identificado com o sociólogo inglês Michael Young. No Brasil, foi Paulo Freire e na França, Althusser; Bourdieu e Passeron; Baudelot e Establet. Na medida do possível, buscamos ler todos os autores apontados por Silva (2007) como sendo pertencentes à teoria crítica de currículo, tanto para compreender as teorias, quanto para verificar, também, a que, ou quais teorias nosso modo de ver o mundo se filiaria. Portanto, acreditamos ter sido de suma importância o passeio panorâmico nas mais diversas teorias curriculares. A seguir, elaboramos um quadro (Quadro 1) seguindo a cronologia elaborada por Silva (2007, p. 30) acerca dos marcos fundamentais tanto da teoria educacional crítica mais geral, quanto da teoria crítica sobre o currículo.

Quadro 1- Marcos da Teoria Crítica de Currículo

\begin{tabular}{|l|l|l|}
\hline ANO & \multicolumn{1}{|c|}{ AUTOR } & \multicolumn{1}{c|}{ OBRA } \\
\hline 1970 & Paulo Freire & A pedagogia do oprimido \\
\hline 1970 & Louis Althusser & A ideologia e os aparelhos ideológicos de Estado \\
\hline 1970 & $\begin{array}{l}\text { Pierre Bourdieu e } \\
\text { Jean-Claude Passeron }\end{array}$ & A reprodução \\
\hline 1971 & Baudelot e Establet & L'école capitaliste en France \\
\hline
\end{tabular}




\begin{tabular}{|c|c|c|}
\hline ANO & AUTOR & OBRA \\
\hline 1971 & Basil Bernstein & Class, codes and control, v. I \\
\hline 1971 & Michel Young & $\begin{array}{l}\text { Knowledge and control: new directions for the } \\
\text { sociology of education }\end{array}$ \\
\hline 1976 & $\begin{array}{l}\text { Samuel Bowles e } \\
\text { Hebert Gintis }\end{array}$ & Schooling in capitalist America \\
\hline 1976 & $\begin{array}{l}\text { William Pinar e } \\
\text { Madeleine Grumet }\end{array}$ & Toward a poor curriculum \\
\hline 1979 & Michel Apple & Ideologia e currículo \\
\hline
\end{tabular}

Fonte: Silva (2007, p. 30).

Um dos teóricos críticos dos processos educacionais foi o educador brasileiro Paulo Freire, cujas teorizações nos serviram como referencial norteador para a análise da formação do bibliotecário brasileiro. Para embasar nossa análise acerca das teorias freirianas, apoiar-nos-emos na pesquisa de Fonseca (2011) o qual analisa a trajetória de Paulo Freire desde o primeiro trabalho acadêmico do professor pernambucano, Educação e Atualidade Brasileira, até o seu Pedagogia do Oprimido, analisando a aproximação de Freire às ideias de Anisio Teixeira, e, por extensão, de Dewey, até o seu afastamento do movimento escolanovista.

As primeiras formulações teóricas de Paulo Freire tiveram gênese e formação no seio do pós-Segunda Guerra Mundial. Sua primeira obra foi Educação e Atualidade Brasileira, escrita em 1959 e trata-se de sua tese de concurso para a cadeira de Filosofia da Educação na Escola de Belas Artes de Pernambuco. A maioria das ideias de Paulo Freire vai ao encontro de uma perspectiva emancipatória dos sujeitos educandos e também dos sujeitos educadores, além de, nos primeiros escritos, conforme Fonseca (2011, p. 11-12) de que havia faltado à formação cultural e histórica do Brasil a efetiva experiência da democracia. A essa consideração acrescentava-se a sua crença na possibilidade de o homem brasileiro aprender a democracia vivenciando-a em experiências como as dos Círculos, porquanto implicaria uma "nova posição em sua vida: a da responsabilidade social e política". Portanto, são ideias inspiradas nas teses do nacional-desenvolvimentismo, ideário elaborado no Instituto Superior de Estudos Brasileiros (ISEB), assim como em autores ligados à filosófica cristã, a exemplo de Karl Jaspers, Gabriel Marcel e Emanuel Mounier (FONSECA, 2011, p. 19).

Ou seja, o pensamento de Paulo Freire influenciou o que se denomina de Pedagogia Crítica (uma filosofia descrita por Henry Giroux como um movimento 
educacional, guiado por paixão e princípio, com o objetivo primordial de auxiliar os estudantes a desenvolverem consciência de liberdade, a reconhecerem tendências autoritárias, e conectar o conhecimento ao poder e à habilidade de tomar atitudes construtivas). A práxis educacional do referido educador pauta-se na dialética educação/realidade e contrapõe-se, portanto, à prática da educação bancária, que é caracterizada como tecnicista, alienante, e que não tem o educando como o agente principal do seu processo de educação, mas sim, como matérias-primas a serem moldadas.

Importante ressaltar que as proposições iniciais de Paulo Freire foram revistas do final dos anos 60 aos anos 70, depois de suas experiências na Guiné-Bissau. Num primeiro momento Paulo Freire destacava as ações culturais e problematizadoras, como geradoras da consciência; depois desse período, ele passou a enfatizar, também, a importância da organização (a ação organizada) e da consciência gerada via experiência profissional, no processo produtivo de trabalho. Já nos anos 90, o tema da cidadania ganha centralidade e é nesse momento em que ele contesta a cidadania liberal, e a neoliberal, e defende uma cidadania como usos plenos dos direitos e deveres pelos cidadãos. Paulo Freire também repudiou a qualidade do neoliberalismo pelo fato deste ser sinônimo de competitividade, a qual é oposta à solidariedade (GOHN, 2009).

Portanto, o Paulo Freire dos primeiros escritos afirma que os sujeitos do processo educativo têm de ser questionadores acerca da sua realidade, tanto educandos, quanto educadores, como forma de que a educação seja a mola propulsora para uma sociedade livre e democrática. Para tanto, a educação deve responder às marcas e aos valores da sociedade, mas nem sempre na perspectiva de corroboração com o que está posto, mas sobretudo, na perspectiva da transformação, da ação do homem no mundo. Para tanto, a atuação do educador tem um papel estratégico, todavia, esta atuação deve pautar-se na "comunic-ação", a fim de que se chegue, realmente, ao homem, que é um ser concreto e inserido numa realidade histórica. A saber, a educação tem de se voltar para o homem-sujeito e não para o homemobjeto (FREIRE, 1967, p. 36).

$\mathrm{O}$ ato do conhecimento torna o educando sujeito do conhecimento, um sujeito transformador, curioso diante do mundo, mundo este que pode ser transformado, inventado e reinventado pelos homens. Paulo Freire analisa a dialética do educador/educando ${ }^{16}$ afirmando que ambos estão sempre em processo de formação, devido à sua condição de criaturas

\footnotetext{
${ }^{16}$ Esta análise de Paulo Freire sofre influência da filosofia hegeliana. Hegel, para exemplificar e diferenciar a consciência independente da consciência dependente utiliza-se da metáfora do senhor e do escravo e afirma que o senhor consegue seu reconhecimento através da consciência do escravo. Para maiores detalhes, cf: Hegel (1992).
} 
inacabadas. O aprendizado, na visão freiriana, refere-se à apropriação do aprendido, transformando-o em apreendido e, portanto, reinventando o conhecimento, aplicando o aprendido nas situações concretas de sua vivência profissional e pessoal.

Paulo Freire acreditava que o processo formativo dos indivíduos só ocorre quando o homem está inserido na sua realidade, de forma a vivenciá-la e que a vivencie de forma crítica com a finalidade de superá-la. Freire (1959, p. 8) afirma que "todo planejamento educacional, para qualquer sociedade, tem que responder às marcas e aos valores dessa sociedade. Só assim é que pode funcionar o processo educativo, ora como força estabilizadora, ora como fator de mudança”. Ou seja, a escola deve estar inserida no seu contexto social, mas não deve ser uma escola imposta pelo centro, mas sim, que ela seja elaborada, planejada, realizada para a cultura da região, ou seja, ela deve refletir a cultura de cada região, mas deve ser una nos objetivos e nas aspirações.

Paulo Freire tem uma concepção sartriana de homem, a saber, que o homem está situado num determinado contexto e deve ser visto conforme sua situação- uma situação de ser um "ser" do trabalho, da transformação do mundo, da práxis, da reflexão. Portanto, é nesta condição que devem estar também os educandos, a saber, numa condição em que os saberes transmitidos não se pautem apenas no transmissivismo, que tanto pautou as práticas educativas; mas também não deve ser um ato de treinamento dos educandos centrado apenas nas técnicas, como propõe a educação neoliberal, pois as técnicas não existem sem os homens. Portanto, a educação deve ser dialógica, e não uma transferência do saber, haja vista que, durante muito tempo, o ato do conhecimento, dentro do ambiente escolar tradicional, parece que, mesmo inconscientemente, ter afinidades com a Teoria da Informação, ou Teoria Matemática da Comunicação de Shannon e Weaver (1948), ou seja, o professor, detentor do saber, é o emissor de uma informação, e utiliza um canal (a voz, os textos), para os educandos (receptores). Caso não tenha nenhuma fonte de ruído, a informação que o professor transmite chegará ao educando e, por meio da significação dessas informações, poderão se tornar conhecimentos, que devem se reproduzidos tal qual o professor transmitiu, sem reformulações. Conforme veremos mais adiante, com maiores detalhes, o processo pode ser representado da seguinte maneira: emissor-canal-receptor. Uma via de única direção. Era como se os educandos fossem apenas receptores do saber e não tivessem nada para transmitir, além de terem de ser eficientes a tal ponto de reproduzir ipsis literis na avaliação o que os textos e o professor tivessem transmitido. Devido a esse motivo, Freire (1981) propõe uma avaliação que não seja uma espécie de inspeção. Na avaliação por ele proposta, os educandos são tão sujeitos quanto os avaliadores, e educandos e educadores avaliam juntos as práticas, 
os desenvolvimentos, os erros, ou os equívocos cometidos porventuramente. Decorre dessa prática o caráter dialógico do modelo avaliativo freiriano, pois em vez de ser fiscalização, a avaliação se torna problematização das ações.

Nesse contexto, Paulo Freire (1967, p. 94) afirma que a nossa educação não é teórica porque falta a comprovação no cotidiano das escolas, das salas de aula, por meio da invenção, da pesquisa, e é nesse sentido que ele afirma que a educação que se pratica nas escolas é palavresca, verbosa, sonora, assistencializadora e, por tudo isso, não comunica, faz apenas comunicados. Para o autor, a educação deve ser praxiológica, ou seja, desenvolver no educando o gosto pela pesquisa, pela constatação, pela revisão dos achados.

Em relação à eficiência nos processos de ensino e de trabalho Freire (1979) afirma que cada vez mais a eficiência deixa de ser a capacidade que têm os seres humanos de pensar, de imaginar, de arriscar-se na atividade criadora para reduzir-se ao mero cumprimento, preciso e pontual, das ordens que vêm de cima. Todavia, uma educação que procura desenvolver a tomada de consciência e a atitude crítica, graças à qual o homem escolhe e decide, liberta-o em lugar de submetê-lo, de domesticá-lo, de adaptá-lo, como faz com muita frequência a educação denominada de bancária por Paulo Freire.

Esse tipo de educação pautada na eficiência dos processos de ensino é aquela na qual o educador aparece como seu indiscutível agente, como o seu real sujeito, cuja tarefa indeclinável é “encher" os educandos dos conteúdos de sua narração. Conteúdos que são retalhos da realidade desconectados da totalidade em que se engendram e em cuja visão ganhariam significação. Eis aí a concepção bancária da educação, em que a única margem de ação que se oferece aos educandos é a de receberem os depósitos, guardá-los e arquivá-los. Todavia, para o autor em lide,

\footnotetext{
Só existe saber na invenção, na reinvenção, na busca inquieta, impaciente, permanente, que os homens fazem no mundo, com o mundo e com os outros. Busca esperançosa também. Na visão "bancária" da educação, o "saber" é uma doação dos que se julgam sábios aos que julgam nada saber. Doação que se funda numa das manifestações instrumentais da ideologia da opressão- a absolutização da ignorância, que constitui o que chamamos de alienação da ignorância, segundo a qual esta se encontra sempre no outro (FREIRE, 2005, p. 67).
}

Ou seja, é desse tipo de educação que tanto o professor, quanto o aluno tem de se libertar, uma educação baseada na eficiência dos métodos de ensino, bem como em sua eficácia; uma educação que visa não a formar homens conscientes e críticos de sua realidade, mas que busca adaptá-lo à sociedade tal qual ela está imposta. Uma educação que vai buscar no mercado de trabalho, nas indústrias, nas fábricas, nos mais variados setores de serviços do 
mundo laboral as bases para formar os programas de ensino como forma de reproduzir, na sala de aula, os mecanismos de ajustamento ao mercado laboral. É esse tipo de educação que o educador brasileiro analisa e propõe uma superação, ou seja, aquele tipo de educação baseada nas características de uma teoria tradicional de currículo, cujos principais expoentes são Bobbitt e Tyler, conforme discutimos anteriormente.

Paulo Freire contrapõe à educação bancária outra forma de educação que ele denominou de problematizadora, que é aquela praticada pelo educador humanista, revolucionário e fundamenta-se na crença no homem, e no seu poder de criação, e é desenvolvida por meio do diálogo; em decorrência desse fato, o processo educativo dever ser dialógico. Esta educação teria de partir do caráter histórico e da historicidade dos homens que estão numa determinada realidade social, que, por ser histórica, é inacabada. Na obra Extensão ou Comunicação? Paulo Freire (1983) afirma que a educação é comunicação, é diálogo, na medida em que não é transferência de saber, mas um encontro de sujeitos interlocutores que buscam a significação de significados, e o que mediatiza os sujeitos do conhecimento, tanto pode ser um fato concreto, do cotidiano dos educandos, quanto as teorias de sala de aula. A tarefa do educador é de ser o problematizador do conteúdo que os mediatiza, e não a de dissertar sobre ele, de doá-lo, como se fosse algo já elaborado, acabado.

Para Paulo Freire (1979), a educação não possui métodos e técnicas abstratas, neutras, pois nem mesmo a realidade é neutra, pois uma coisa é a adaptação, que é uma adequação, um ajuste do corpo às condições materiais, climáticas, etc. Outra, bem diferente, é a inserção no mundo, pois se refere a uma tomada de decisão com vistas à intervenção. Todavia, isso só será alcançado se a educação se envolver numa postura crítica, que tenha uma visão crítica do contexto na qual está inserida e que elabore instrumentos pedagógicos conforme essa postura crítica diante do mundo.

As ideias do sociólogo português Sousa Santos vão ao encontro das ideias de Paulo Freire quando afirma que a superação da contradição entre a escola e a realidade dar-seá quando não mais se usar apenas a linguagem técnica (que é objeto de dominação), mas também, quando não se usar apenas a linguagem popular, mas se usar um conjunto de conceitos recriados, ampliados de tal forma que comporte todas as configurações linguísticas intermédias, os quais o autor denominou de linguagem técnica popular (SOUSA SANTOS, 1989, p. 117).

Para a concepção de uma educação como prática da liberdade, a sua dialogicidade começa, não quando o educador-educando se encontra com os educandos-educadores em uma situação pedagógica, mas antes, quando aquele se pergunta em torno do que vai dialogar com 
estes. Todavia, o que se espera da educação na contemporaneidade é que se lhe confira uma nova perspectiva, principalmente a partir das transformações ocasionadas com o advento das Tecnologias de Informação e de Comunicação e a partir da configuração da Sociedade da Informação. Que educação se busca nos tempos contemporâneos? Uma educação crítica que faça surgir sujeitos questionadores, capazes de romper com o que afirmaram e colocaram para ele como forma de vida, que rompam com o silêncio que se lhes fora imposto, que faça florescer os ideais de humanidade, ou uma educação voltada para a manutenção do status $q u o$ ? Uma educação que tenha uma pulsão pelo novo, conforme colocou de forma crítica a filósofa Olgária Matos (2009), ou uma educação que saiba se utilizar dos conhecimentos que herdamos da tradição num mundo novo? A respeito desta colocação, Arendt (2009, p. 243) se posiciona da seguinte maneira:

Exatamente em benefício daquilo que é novo e revolucionário em cada criança é que a educação precisa ser conservadora; ela deve preservar essa novidade e introduzi-la como algo novo em um mundo velho, que, por mais revolucionário que possa ser em suas ações, é sempre, do ponto de vista da geração seguinte, obsoleto e rente à destruição.

Não acreditamos que a educação tenha sempre de se pautar pela mudança incessante, pela pulsão pelo novo, mas sim, deve transmitir, principalmente, os conhecimentos que herdamos de gerações anteriores e os que estão sendo produzidos na contemporaneidade e que os dois tipos de conhecimentos atuem de forma dialógica tendo em vistas estar em consonância com a sua realidade. A educação tem sentido porque o mundo não é necessariamente isto ou aquilo, porque os homens são tão projetos quanto podem ter projetos para o mundo. A educação tem sentido porque homens e mulheres aprenderam que é aprendendo que se fazem e refazem, porque mulheres e homens se puderam assumir como seres capazes de saber, de saber que sabem, de saber que não sabem. De saber melhor o que já sabem, de saber o que ainda não sabem. A educação tem sentido porque, para serem, mulheres e homens, precisam de estar sendo. Se mulheres e homens simplesmente fossem, não haveria porque falar em educação (FREIRE, 2000). Esta visão também vem ao encontro daquilo que a filósofa Arendt (2009, p. 223) afirmara ser a essência da educação, ou seja, a natalidade, o fato de que seres humanos nascem para o mundo.

O legado de conhecimentos acumulados pela sociedade tem de ser ressignificado constantemente pelos indivíduos de modo que, quando os novos conhecimentos forem produzidos o indivíduo tenha elementos para saber como lidar com o novo, pois ele sempre vem. A educação, independentemente do contexto histórico, deve se basear no legado da 
tradição, como forma de inserir as gerações mais novas, as que estão tentando se apropriar do mundo que se lhes está posto; mas também, se deve inserir na educação conhecimentos que são criados e recriados pela sociedade como forma de ressignificar os processos educacionais. Nem só o tradicional, nem apenas a pulsão pelo novo como temos contemporaneamente, mas sim, numa síntese entre os dois tipos de formação. Ou seja, conforme nos coloca Paulo Freire (1983), se pretendemos a dialogicidade da educação não podemos prescindir de um conhecimento que foi construído previamente, pois será a partir desse conhecimento que se poderão organizar os conteúdos programáticos da educação que encerrará um conjunto de temas sobre os quais o educador e o educando, como sujeitos do conhecimento, exercerão a cognoscibilidade. Estas palavras vão ao encontro do pensamento da filósofa Arendt (2009, p. 243):

\footnotetext{
A crise da autoridade na educação guarda a mais estrita conexão com a crise da tradição, ou seja, com a crise de nossa atitude face ao âmbito do passado. É sobremodo difícil para o educador arcar com esse aspecto da crise moderna, pois é de seu ofício servir de mediador entre o velho e o novo, de tal modo que sua própria profissão lhe exige um respeito extraordinário pelo passado.
}

Este pensamento também vem ao encontro daquilo que Paulo Freire (2000) tratou no seu Pedagogia da Indignação, ou seja, que é tão errado os pais deixarem os filhos entregues a si mesmos, com plena liberdade de fazerem o que querem, abrindo mão até mesmo da sua autoridade, quanto os pais subordinarem seus filhos à tirania da autoridade, que faz com que as crianças fiquem caladas, cabisbaixas, bem comportadas e que, submissas, nada podem. Portanto, a proposta educacional dos últimos escritos de Paulo Freire refere-se ao exercício da cidadania, e não mais de dominadores e dominados, e de tomada de consciência, como nos primeiros escritos.

Portanto, como forma de superação das formas pedagógico-educacionais vigentes, Paulo Freire propõe uma pedagogia do oprimido, ou seja, uma educação que possibilite a libertação tanto do opressor, quanto do oprimido. É por meio da tomada de consciência de ambos os atores do processo de opressão (opressor e oprimido), que se realiza por meio da mediação do mundo, que este mundo conscientiza-se como projeto humano: o homem faz-se livre. Os opressores se apropriam de todos os mecanismos possíveis para que a ordem permaneça inalterada, controlam os oprimidos e se apropriam também da ciência "como instrumento para suas finalidades. Da tecnologia, que usam como força indiscutível de manutenção da 'ordem' opressora, com a qual manipulam e esmagam” (FREIRE, 2005, p. 52). 
Para que a escola tenha essa prática libertadora é necessário que ela seja uma instituição local "feita sob medida para a cultura da região, diversificada, assim, nos seus meios e recursos, embora una nos objetivos e aspirações comuns" (TEIXEIRA, 1957 apud FREIRE, 1959, p. 91). Portanto, Freire (1959, p. 92) afirma que "somente uma escola centrada democraticamente no seu educando e na sua comunidade local, vivendo as suas circunstâncias, integrada com seus problemas, levará os seus estudantes a uma nova postura diante dos problemas de seu contexto.” Exemplificando, Freire (1978) afirma nas suas Cartas à Guiné-Bissau que a prática realizada ou realizando-se no contexto A só se torna exemplar no contexto B se os que atuam neste contexto a recriam, recusando, assim, a tentação dos transplantes mecânicos e alienantes. É tão errado o fechamento a experiências realizadas em outros contextos quanto à abertura ingênua a elas, de que resulte a sua importação pura e simples, ou seja, Paulo Freire fala aqui das negociações culturais.

Com vistas à superação de uma educação bancária, que o autor em lide afirma ser bacharelesca, verbosa, é necessária uma primeira revisão, e urgente, na programação e no procedimento dessas escolas de formação do professor primário e de outros profissionais, de forma que elas identificassem seu currículo com a nossa atualidade. A que o fizesse sintonizar-se com aspectos mais gritantes desta atualidade, de que resultasse o esvaziamento de sua ênfase bacharelesca e, em lugar dela, as oportunidades de convivência do aluno-mestre com o agir educativo aparecessem. Isto implicaria, na verdade, numa modificação radical na estrutura destas escolas de que surgisse um currículo plástico, em lugar do ainda rígido currículo por matérias. É ainda esta clareza política, em face da realidade e da própria educação, clareza associada a permanente vigilância no sentido da preservação da coerência entre nossa prática e o projeto da nova sociedade, que nos faz evitar o risco de reduzir a organização curricular a um conjunto de procedimentos técnicos de caráter neutro. A organização do conteúdo programático da educação, seja ela primária, secundária, universitária ou se dê ao nível de uma campanha de alfabetização de adultos, é um ato eminentemente político (FREIRE, 1959, p. 108).

Em relação ao conteúdo programático da educação, Paulo Freire afirma que não é possível ensinar técnicas sem problematizar toda a estrutura em que se darão estas técnicas. E a educação deve ter como ponto de partida a busca do conteúdo programático, em torno do qual os sujeitos exercerão sua ação do conhecer. Esses conteúdos não podem ser escolhidos 
por um ou por outro dos polos dialógicos (professor/aluno), isoladamente ${ }^{17}$. Corroborando, Paulo Freire (1978) afirma que não seria realizável uma educação voltada para a concretização de valores como a solidariedade, a responsabilidade social, a criatividade, a disciplina a serviço do interesse comum, a vigilância, o espírito crítico se nesta educação os educandos continuassem a ser, como na educação colonial, meros recipientes de conhecimentos empacotados, a eles transferidos pelos educadores.

Em relação ao processo educativo no âmbito das universidades, Carlos Dias, em conversa com Paulo Freire (1978), afirmava que seria impossível conceber o trabalho fora da educação como se fosse algo a que aspirássemos e para o que nos preparássemos em lugar de tomá-lo como o centro mesmo da formação e, para tanto, seria tomado como lema "trabalhar estudando e estudar trabalhando". Todavia, isto não tem nada a ver com a unidade entre trabalho e estudo que se realiza nas sociedades capitalistas, nos chamados centros de aprendizagem industrial, viveiros em que se cultivam os futuros operários para vender a sua força de trabalho à classe empresarial. Portanto como forma de superar esta contradição,

Parece-nos indispensável, para qualquer universitário brasileiro de hoje, estudo, não só teórico, mas acompanhado da observação direta, de nossa realidade política em elaboração. De nossa realidade econômica. O debate de nossos problemas agudos. Estudos e debates que fossem feitos através de disciplinas como a Sociologia, cuja presença em todos os cursos universitários, como estudo geral ou especializado, nos parece de grande importância, e a teoria política. Sociologia e Teoria Política, nunca, porém, verbalizados (FREIRE, 1959, p. 116).

Podemos perceber que Paulo Freire (1959, p. 117) em seus escritos se preocupou com a formação de profissionais capacitados, por meio de estudos teóricos, de observações diretas da realidade em que eles atuarão; debate não apenas acerca dos aspectos relacionados à profissão do aluno, mas relacionados, também, com a realidade a qual o educando está inserido. Esses estudos e debates seriam realizados através de disciplinas como a Sociologia e a Teoria Política, cujas presenças em todos os cursos universitários, como estudo geral ou especializado, parecem, para o educador brasileiro, de grande importância.

Mesmo numa formação em nível profissional, o aspecto humanista da educação tem de estar presente, pois a ciência e a tecnologia, na sociedade revolucionária, têm de estar a serviço da humanização dos homens. Noutro momento, afirmou que a pesquisa e o ensino têm de caminhar lado a lado, pois um não vive sem o outro, pois o professor também aprende

\footnotetext{
${ }^{17}$ É importante lembrarmos aqui que o mesmo Paulo Freire (1983) do "Extensão ou Comunicação" afirmara que não podemos prescindir dos conhecimentos já constituídos, pois é a partir deles que vamos construir os conteúdos programáticos da educação. Mas também não podemos sozinhos escolher esses conteúdos e injetálos nos educandos. Daí o processo de dialogicidade envolvido nas formulações freirianas.
} 
enquanto ensina, pois ele deve continuar buscando, procurando. Portanto, Freire (1997, p. 18) afirma que "transformar a experiência educativa em puro treinamento técnico é amesquinhar o que há de fundamentalmente humano no exercício educativo: o seu caráter formador". Finalizamos com uma frase de Paulo Freire em seu Pedagogia da Indignação:

Se o sonho morreu e a utopia também, a prática educativa nada mais tem que ver com a denúncia da realidade malvada e o anúncio da realidade menos feia, mais humana. Cabe à educação como prática rigorosamente pragmática- mas não no sentido deweyano- treinar os educandos no uso de técnicas e princípios científicos. Treiná-los, nada mais. O pragmatismo neoliberal não tem nada que ver com formação (FREIRE, 2000, p. 56).

Em relação às teorias pós-críticas de currículo percebemos que as suas preocupações remetem-se às preocupações da sociedade pós-moderna com a educação, ou seja, elas se voltam para determinados aspectos da realidade para constituir seu programa curricular. Portanto, Silva (2007) afirma existir os currículos que se pautam no multiculturalismo, nas relações de gênero e na pedagogia feminina, no pós-modernismo, no pós-estruturalismo, nos estudos culturais, dentre outros aspectos, ou seja, são currículos que se apegam a determinadas facetas da sociedade para construir seus projetos de educação. $\mathrm{O}$ problema nesse tipo de currículo é que corrobora com a ideologia do sistema capitalista, haja vista que este sistema, enquanto um projeto globalizante, nunca é contestado, pois a atenção fica voltada apenas para determinados aspectos fragmentados da sociedade pós-moderna.

Em síntese, os principais conceitos que definem cada teoria curricular, conforme Silva (2007, p. 17) são: a) Teorias Tradicionais: (enfatizam) ensino, aprendizagem, avaliação, metodologia, didática, organização, planejamento, eficiência e objetivos. b) Teorias Críticas: (enfatizam) ideologia, reprodução cultural e social, poder, classe social, capitalismo, relações sociais de produção, conscientização, emancipação e libertação, currículo oculto e resistência. c) Teorias Pós-Críticas: (enfatizam) identidade, alteridade, diferença, subjetividade, significação e discurso, saber-poder, representação, cultura, gênero, raça, etnia, sexualidade e multiculturalismo.

A partir dos estudos das mais variadas teorias curriculares e dos autores que as sustentam, nossas análises sobre os currículos dos cursos de Biblioteconomia serão realizadas tendo como norte teórico as formulações da teoria crítica proposta por Paulo Freire, haja vista que é uma das poucas teorias que propõe um ir-além dos modelos que estão postos. Portanto, para termos mais subsídios para a análise dos Cursos de Biblioteconomia, iremos realizar um passeio panorâmico pela história, pelos paradigmas e pela epistemologia da Ciência da 
Informação, haja vista que a Biblioteconomia é um de seus ramos constituintes e as duas ciências se influenciam mutuamente.

\subsubsection{Impactos do neoliberalismo sobre os currículos}

Conforme vimos discutindo até o presente momento, se outrora, a educação estava mais voltada para a transmissão dos saberes que eram herdados de geração a geração e a transmissão dos conhecimentos era realizada por uma interação face a face entre professor e aluno, e essa transmissão era concernente aos conhecimentos herdados de uma geração a outra; com o advento da modernidade, a escola, e aqui também se inclui a universidade, além de transmissão do saber, ela passou, também, a produzir conhecimentos e a se aliar a uma ideologia de mercado. Por exemplo, se noutro tempo os saberes constituídos eram autônomos, num determinado ponto da modernidade, eles passam a ser o principal agente de acumulação do capital.

É no contexto de análise acerca do neoliberalismo em relação à educação que Sella (2002, p. 51) elenca algumas características do sistema neoliberal: 1) A raiz é a racionalidade pós-moderna. Hoje é racional tudo aquilo que maximiza o lucro. A competição se torna algo de natural ou criacional. 2) De fato, a liberdade pós-moderna se constrói a partir do ego e não do outro, e esse individualismo quebra a relação com a alteridade. Quais as consequências do neoliberalismo no campo educacional? Para os neoliberais, a educação só inserirá o indivíduo na sociedade se eles adquirirem alguma técnica, e decorre desse fato as escolas ensinarem a seus alunos técnicas de computação, de leitura. Conforme afirma Gentilli (1996) o diagnóstico inicial decorre do argumento central na retórica construída pelos tecnocratas neoliberais: 1) atualmente, inclusive nos países mais pobres, não faltam escolas, faltam escolas melhores; 2) não faltam professores, faltam professores mais qualificados; 3) não faltam recursos para financiar as políticas educacionais, ao contrário, falta uma melhor distribuição dos recursos existentes; 4) transformar a escola supõe um enorme desafio gerencial; 5) promover uma mudança substantiva nas práticas pedagógicas, tornando-as mais eficientes; 6) reestruturar o sistema para flexibilizar a oferta educacional; 7) promover uma mudança cultural, não menos profunda, nas estratégias de gestão (agora guiadas pelos novos conceitos de qualidade total); 8) reformular o perfil dos professores, requalificando-os; implementar uma ampla reforma curricular, etc.

As reformas propostas pelo neoliberalismo para o campo educacional são guiadas pelo crescente papel do saber na economia e pressionam para a descentralização, 
padronização dos métodos e dos conteúdos, novo gerenciamento da escola, profissionalização dos professores. Se outrora, a escola era pautada pelo valor social, cultural e político do saber, e interpretado de diversas formas, conforme as diferentes correntes político-ideológicas e modelos pedagógicos ${ }^{18}$; na contemporaneidade, ela passa a se pautar em objetivos de competitividade que prevalecem na globalização (LAVAL, 2004, p. XIII). Outros autores que já haviam analisado esta questão são Gentili e Silva (1999, p. 19) para quem no neoliberalismo,

Tudo se reduz, nessa solução [neoliberal], a uma questão de melhor gestão e administração e de reforma de métodos de ensino e conteúdos curriculares inadequados. Para problemas técnicos, soluções técnicas, ou melhor, soluções políticas traduzidas como técnicas (tal como a privatização, por exemplo). É nesse raciocínio que se insere o discurso sobre a qualidade e sobre a gerência da qualidade total.

Há quatro posicionamentos em relação à qualidade de ensino, conforme aponta Libâneo (2006, p. 41). O primeiro seriam os discursos marcados por análises externas à escola, análises de conjunto, genéricas, muito a gosto de filósofos e sociólogos da educação. Aqui o autor distingue duas abordagens: a) uma que é crítica e identifica posições de denúncia do atrelamento da escola a interesses políticos e econômicos, por exemplo, atualmente, ao modelo neoliberal, ao mercado, etc. b) outra é chamada de posição pós-crítica ou pósmoderna, que faz uma impetuosa crítica à escola por considerar que ela lida com o conhecimento com base na razão, quando a razão já estaria fora de moda; que os saberes sistematizados têm cumplicidade com as relações de poder; que não contempla as diferenças sociais e culturais, etc. Nessa abordagem a escola ideal seria aquela despojada de saberes iluministas e impregnada do lúdico, do imaginário, do cultivo da diferença, do lado prazeroso, etc. O segundo posicionamento refere-se a propostas voltadas para aspectos internos do funcionamento da escola centrando-se, especificamente, nas questões organizacionais. Presume-se que, tornando mais eficazes as formas de organização, estarão criando as condições para melhorar a aprendizagem. Há aqui também duas abordagens. Na primeira, pedagogicamente, eliminam-se as series e introduzem-se os ciclos de escolarização, implantase a progressão automática, e a qualidade de ensino virá em acréscimo. Já a segunda aposta na gestão participativa, na participação das decisões, na eleição de diretores com os professores se envolvendo mais com a escola, e a melhoria do ensino virá em acréscimo. O terceiro posicionamento refere-se a mudanças na organização curricular, com vistas à melhoria do

\footnotetext{
${ }^{18}$ Acerca dos diferentes modelos pedagógicos e sua evolução cronológica ver também CAMBI (1999).
} 
ensino. A qualidade do ensino será obtida de duas formas: na primeira, a escola enfatizará mais os processos do que os produtos, pois não importam os resultados, mas os processos, portanto, se fala de um currículo baseado nas experiências cotidianas. Na segunda, percebe-se a recusa dos currículos tradicionais, do currículo por grades de disciplinas, adotando-se um currículo integrado. Finalmente, o quarto posicionamento está ligado a formulações teóricas e ações psicopedagógicas da escola. Uma visão psicopedagógica da escola é voltada para as dimensões internas, tais como a mediação do ensino e as formas de comunicação, as formas de estruturação do conhecimento e os processos internos de sua apropriação pelos alunos.

Para a contextualização dos processos educativos na ambiência do contexto neoliberal, mas voltando-se para o caso brasileiro, uma autora que vale mencionar é Sônia Alem Marrach (2001), com seu artigo intitulado Neoliberalismo e Educação, o qual está inserido no livro Infância, Educação e Neoliberalismo de Silva Júnior et al. (2001), o qual analisa as implicações do neoliberalismo para o campo da educação, apontando três objetivos que o sistema neoliberal propõe para esse setor social, quais sejam: 1) atrelar a educação escolar à preparação para o trabalho e a pesquisa acadêmica ao imperativo do mercado ou às necessidades da livre iniciativa. Fala em nova vocacionalização, isto é, numa profissionalização situada no interior de uma formação geral, na qual a aquisição de técnicas e linguagem da informática e conhecimentos de matemática e ciência adquirem relevância. É uma educação que busca a valorização das técnicas de organização, o raciocínio de dimensão estratégica e a capacidade de trabalho cooperativo. 2) Outro objetivo é tornar a escola um meio de transmissão dos seus princípios doutrinários. O que está em questão é a adequação da escola à ideologia dominante e não a busca de uma escola emancipatória e que torne o educando o sujeito do processo educativo. 3) Fazer da escola um mercado para os produtos da indústria cultural e da informática ${ }^{19}$, o que aliás é coerente com a ideia de fazer a escola funcionar de forma semelhante ao mercado. É como consumidores que o neoliberalismo vê alunos e pais de alunos.

Para Marrach (2001, p. 42) as palavras de ordem do discurso neoliberal para a educação são: 1) qualidade total. 2) Modernização da escola. 3) Adequação do ensino à competitividade internacional. 4) Nova vocacionalização. 5) Incorporação das técnicas e

\footnotetext{
${ }^{19}$ A teoria neoliberal da mudança tecnológica se sustenta nos poderes coercivos da competição para levar à busca de novos produtos, de novos métodos de produção e de novas formas organizacionais. Mas esse impulso se incorpora a tal ponto ao senso comum dos empreendedores que se torna um fetiche: a crença de que para todo e qualquer problema há um remédio tecnológico. Os desenvolvimentos tecnológicos podem sair do controle quando setores, que só se dedicam à inovação tecnológica, criam novos produtos e novas maneiras de fazer as coisas para os quais ainda não há mercado (produzem-se novos produtos farmacêuticos para os quais se inventam novas doenças) (HARVEY, 2008, p. 79).
} 
linguagens da informática e da comunicação. 6) Abertura da universidade aos financiamentos empresariais. 7) Pesquisas práticas, utilitárias, produtividade.

Em relação à universidade pública, o discurso neoliberal condena o populismo, o corporativismo, o ensino ineficaz e a falta de produtividade e propõe a ela: a) que parte dos estudantes arque com os custos do ensino nas universidades federais. b) Novos tipos de contrato de trabalho, que tendem a eliminar a dedicação exclusiva e ampliar o quadro de professores de tempo parcial. c) Que vá buscar recursos para suas pesquisas nas empresas industriais e comerciais (MARRACH, 2001, p. 51). Isso favoreceria as áreas de microeletrônica, biotecnologia, engenharia de produção e administração em detrimento da desvalorizada área de humanas. Outro autor que analisa o neoliberalismo no âmbito das universidades é Sousa Santos (1989, p. 131), afirmando que:

\footnotetext{
Durante muito tempo as universidades que detiveram o monopólio da investigação científica, perderam-no em favor dos governos e da indústria. Na Europa foi, sobretudo notória, a criação de grandes laboratórios e centros de investigação subsidiados pelo Estado, enquanto nos Estados Unidos (quase sempre com interesse militar) com as universidades e as grandes empresas. Entre as consequências desse processo podemos salientar as que se referem às transformações nas condições do trabalho científico. A esmagadora maioria dos cientistas foi submetida a um processo de proletarização no interior dos laboratórios e centros de investigação. Expropriados dos meios de produção, passaram a ser dependentes de um chefe mais ou menos invisível, "dono" dos métodos, das teorias, dos projetos e dos equipamentos. A ideologia liberal da autonomia da ciência transformou-se em caricatura amarga aos olhos dos trabalhadores científicos. [...]. A situação dos cientistas nos laboratórios das indústrias tornou-se particularmente penosa, dadas as pressões no sentido da rentabilidade industrial da investigação.
}

Portanto, conforme discutimos neste subitem, a educação vem sofrendo cada vez mais influência da pós-modernidade e do neoliberalismo à medida que ela se volta, estritamente, ao treinamento para o mercado de trabalho e não para o exercício da plena liberdade dos sujeitos da educação. Devido a este fato, a educação, também passa a assimilar os termos e os conceitos oriundos do mundo mercadológico e acaba por inserir essas terminologias nos currículos, independentemente do nível de ensino, se fundamental, médio, técnico ou superior.

\subsection{Ciência da Informação e Biblioteconomia}

Para buscarmos compreender como se apresentam os conteúdos referentes à mediação da informação no currículo de formação do bibliotecário brasileiro e qual o papel da mediação da informação e da cultura na estruturação desses currículos, iremos buscar 
delinear, minimamente, o que entendemos acerca de Ciência da Informação e, posteriormente, de mediação.

Em primeiro lugar, é importante salientar que iniciar uma historicização acerca da Ciência da Informação não é uma tarefa fácil, principalmente, porque a área não possui uma origem histórica definida, não possui um fundador que seja consenso pelos pesquisadores, fazendo surgir, portanto, discussões acerca da identidade da área, característica esta de uma ciência que surgiu num período em que estavam se manifestando as "teses dos fins", a saber, fim da história, fim da política, etc. No entanto, depois de várias idas e vindas à literatura e à historicidade da Ciência da Informação, um bom ponto de partida parece-nos o de Ortega (2004, p. 10), quando afirma que:

\footnotetext{
Considera-se que a Biblioteconomia deu origem à Bibliografia, que fundamentou a Documentação, que por sua vez, forneceu insumos à constituição da Ciência da Informação, também denominada de Informatologia. A Ciência da Informação é entendida como a preocupação com a unidade fundamental do saber, através de estudos interdisciplinares e de métodos como o estrutural. Engloba o conjunto das disciplinas voltadas para a produção, comunicação e consumo da informação que, chamadas, por isso, de ciências da informação, passaram a ser consideradas como uma só ciência da informação. A adoção do termo Ciência da Informação no idioma inglês, pode ser verificada já em 1958, com a criação, em Londres, do Institute of Information Scientists, e, dez anos depois, com a mudança de denominação do American Documentation Institute para American Society and Technology, o mesmo ocorrendo com as escolas de Biblioteconomia e publicações.
}

Portanto, acreditamos que, a partir da década de 1950, podemos perceber já o embrião daquilo que, posteriormente, passou a denominar-se Ciência da Informação em meio às discussões da Biblioteconomia, da Biblioteconomia Especializada e da Documentação. $\mathrm{O}$ que, na realidade, seria essa Ciência da Informação? Que áreas ela compreende? Quando se dá a sua gênese? Que profissional atua nas questões da Ciência da Informação? Podemos falar de Ciência da Informação ou de Ciências da Informação?

É num contexto de imprecisão do tempo, do espaço, das identidades, que é o momento contemporâneo, no contexto de uma ciência que assume uma dimensão pragmática, como força de produção na acumulação do capital que surge a Ciência da Informação. Portanto, traçamos, neste momento, um panorama sobre a constituição da Ciência da Informação, com paradas reflexivas na política, na cultura, na economia, buscando delimitar percursos analíticos que ajudem a compreender o desenvolvimento desta ciência no desenho do cenário contemporâneo.

As ideias de Ortega (2004), em relação à origem da CI, vão ao encontro da visão de Le Coadic (1996) acerca da gênese da área, uma vez que, para o referido autor, a CI tem 
origem anglo-saxônica e nasceu da Biblioteconomia, tomando, portanto, como objeto de estudos, a informação fornecida pelas bibliotecas e centros de documentação, tendo, a saber, depois disso, se apropriado das informações produzidas pelo desenvolvimento das ciências e das tecnologias no período do pós-guerra. Outro autor que vem a corroborar que a Ciência da Informação é oriunda da Biblioteconomia e, a posteriori, da Documentação, é Capurro (2003, p. 7), para quem a CI é oriunda tanto da biblioteconomia clássica (estudo dos problemas da transmissão de mensagens), quanto da computação digital (impacto da computação nos processos de produção, coleta, organização, interpretação, armazenagem, recuperação, disseminação, transformação e uso da informação registrada em documentos impressos). Portanto, conforme Capurro (2003) a Ciência da Informação está baseada em três paradigmas: físico, social e cognitivo.

Conforme o paradigma ${ }^{20}$ físico, a área em lide teria tido início com a teoria da information retrieval baseada numa epistemologia fisicista. Este paradigma físico está relacionado com a Teoria da Informação, de Shannon e Weaver (1949) e com a Cibernética, de Norbert Wiener (1961). O paradigma físico preocupa-se com a transmissão de sinais entre máquinas de comunicação, excluindo do processo comunicacional os seres humanos e foi um modelo que predominou durante muito tempo na CI. Um autor que é ligado ao paradigma físico da informação é Buckland (1991), reconhecido pesquisador na área de Ciência da Informação, que propôs a informação como coisa afirmando ser neste tipo de informação que bibliotecários e documentalistas pautam sua prática. Em seu artigo Information as thing o autor em lide distingue três tipos de significados do termo informação, a saber: informação como processo, informação como conhecimento e informação como coisa. Para este autor, é curioso e contraditório que informação seja conceituada como a medida da redução de incerteza e o próprio termo informação seja ambíguo. A informação como processo refere-se a uma mudança no receptor ao receber informação (a informação aqui seria entendida como signo); informação como conhecimento é aquilo que o receptor percebe na informação como processo e seria, portanto, o fato, o signo; informação como coisa é atribuída a objetos, mais especificamente, seria qualquer expressão, descrição ou representação e é esse tipo de informação que os sistemas de informação lidam diretamente - dados (qualquer registro de dados armazenado num computador), textos, documentos e objetos (a informação aqui é entendida como sinal).

\footnotetext{
${ }^{20}$ Conhecimento que origina o conhecimento de um campo científico, que serve de base e modelo para estudos futuros. Maiores detalhes ver Kuhn (2003).
} 
Outro paradigma da Ciência da Informação é o paradigma cognitivo, o qual remonta a Otlet e a La Fontaine, também tido como outro dos fundamentos da CI, inclui a cognição humana no processo. A Documentação e, em seguida, a Ciência da Informação, têm a ver, aparentemente, em primeiro lugar, com os suportes físicos do conhecimento; mas, na realidade, sua finalidade é a recuperação da própria informação, ou seja, o conteúdo de tais suportes. Esse paradigma trata de ver de que forma os processos informativos transformam ou não o usuário, entendido, em primeiro lugar, como sujeito cognoscente, possuidor de modelos mentais do mundo exterior que são transformados durante o processo informacional. Esse paradigma sofreu muita influência da Equação Fundamental da Ciência da Informação de Brookes (1980), que é representada da seguinte forma: $\mathrm{K}(\mathrm{S})+\Delta \mathrm{K}=\mathrm{KS}+(\mathrm{s}+\Delta \mathrm{S}) \rightarrow \Delta \mathrm{I}$, que significa: o conhecimento de um sujeito $K(S)$ é transformado em outro conhecimento $\mathrm{KS}+(\mathrm{s}+\Delta \mathrm{S})$, quando a informação $\Delta \mathrm{I}$ é assimilada pelo sujeito (que a assimila conforme as condições sociais e cognitivas de cada indivíduo). $\Delta \mathrm{S}$ é o efeito da transformação pelo sujeito. Se $\Delta \mathrm{I}$ não se transforma em $\Delta \mathrm{S}$, o sujeito não reconheceu a informação. Esse paradigma cognitivo percebe a informação como algo separado do usuário e deixa de lado os condicionamentos sociais e materiais do existir humano (CAPURRO, 2003, p. 10). A informação, conforme esse paradigma, é um signo, tem uma perspectiva qualitativa e não quantitativa, como a do paradigma físico. Esse paradigma da CI aborda a informação em seus processos de significação para os sujeitos cognoscentes. Está mais ligada às teorias de Peirce e de Saussure. Para Saussure, o signo é arbitrário, nada há, por exemplo, na palavra gato, que lembre um gato (tanto que, em inglês, a palavra é cat). Já para Peirce, um signo é aquilo que para alguém representa algo, está na mente do sujeito, é aquilo que significa para o sujeito.

O terceiro paradigma da Ciência da Informação é o paradigma social, cujo principal representante é Bernd Frohmann, o qual critica a epistemologia baseada em conceitos como imagens mentais, mapas cognitivos, modelos do mundo, realidades internas, etc. (CAPURRO, 2003, p. 10, grifo do autor). Frohmann considera o paradigma cognitivo idealista e associal. Na palestra $O$ caráter social, material e público da informação, Frohmann (2006, p. 19) afirma que "a importante tarefa dos estudos da informação deve se pautar em como conciliar estudos sobre o fenômeno da informação em nosso tempo, com estudos e práticas sociais e públicas, das realidades políticas, da economia e da cultura". Ou seja, os estudos acerca da informação devem estar voltados também para a sua contextura histórico-social, a fim de que as interpretações acerca do fenômeno informacional não se deem apartadas de seu tempo. 
Portanto, o que Frohmann (2006, p. 21) argumenta é que muito do caráter social e público da informação, depende de sua materialidade, e que, sem a atenção à questão da materialidade da informação, grande parte das considerações sociais, culturais, políticas e éticas, tão importantes para os estudos da informação, se perdem. A materialidade da informação é o documento, daí a importância da documentação para os estudos da informação, pois aquela é a materialização desta. Frohmann (2006, p. 26) afirma que "os estudos de Bruno Latour, mostram como as práticas científicas podem contribuir para os estudos da materialização documentária da informação”.

É, portanto, a partir destes três paradigmas que os estudos da Ciência da Informação se pautam e que até mesmo a sua historicidade é narrada. Para os que se apoiam no paradigma físico, a área teria tido início a partir da década de 1945/1950, com o advento das Tecnologias de Informação e de Comunicação, momento em que houve a explosão informacional e que, a partir daquele momento, seria necessário criar mecanismos de controle da informação em larga escala, uma vez que a informação havia se tornado mundializada. Este paradigma está relacionado à Teoria da Informação de Shannon e Weaver e com a Cibernética de Norbert Wiener (1961). Exemplo de autor que se apoia no paradigma físico de informação é Saracevic (1996, p. 42) para quem a CI teve sua origem no bojo da revolução científica e técnica que se seguiu à Segunda Guerra Mundial e o ímpeto de desenvolvimento e a própria origem da CI podem ser identificados com o artigo de Vannevar Bush, o qual identificou a explosão informacional e propôs o MEMEX para solucionar o problema. Mesmo considerando que a Ciência da Informação surgiu no período do pós-Segunda Guerra Mundial, Saracevic (1996, p. 48) afirma que os problemas acerca da explosão informacional já haviam ocupado as mais variadas profissões no decorrer dos tempos.

Foi também nesse período que foi cunhado o termo Ciência da Informação, em 1955, pelo inglês Jason E. L. Farradane, porém, sem a sua definição (WOLEDGE, 1983; SHAPIRO, 1995 apud BENTES PINTO, 2007, p. 115). Foi somente na segunda reunião do Georgia Institute of Technology, em 1962, que foi elaborado o primeiro conceito de Ciência da Informação, por Taylor (1966), no artigo Professional aspects of Information Science and Technology, o qual serviu de base para o de Borko (1968), para quem a Ciência da Informação é uma ciência interdisciplinar derivada de várias outras e que abrange um corpo de conhecimentos que estão relacionados desde a origem até a utilização da informação (PINHEIRO, 2005, p. 17).

O artigo de Borko (1968) ressalta a interdisciplinaridade da Ciência da Informação, a qual é objeto de preocupações de vários autores que concordam ou não com a 
perspectiva da interdisciplinaridade, dentre os quais, além de Pinheiro (2005), encontramos Saracevic (1996); Smit; Tálamo e Kobashi (2004); Bentes Pinto (2007); Le Coadic (2007); Mueller (2007); Souza, F. (2007), dentre outros.

Saracevic (1996) afirma que a interdisciplinaridade foi introduzida na CI pela variedade da formação das pessoas que se preocupam com os problemas que ela trata. Devido a este fato, a CI mantém relações interdisciplinares com a Biblioteconomia, Ciência da Computação, Ciência Cognitiva e a Comunicação. Já Smit; Tálamo e Kobashi (2004) afirmam que a alta proporção de noções emprestadas de outras ciências e incorporadas ao discurso da CI é reveladora de uma unidade formal, que não reflete uma interdisciplinaridade real, mas um "empréstimo" de termos de outras áreas, sem que tenha havido uma adaptação dos conceitos aos propósitos da área. Numa visão contrária a essa perspectiva encontramos Bentes Pinto (2007, p. 137, grifo nosso) a qual afirma que:

A partir da História da Ciência da Informação, fica mais evidente o fato de que este campo de conhecimento, pela sua própria natureza de construção e de seu objeto de estudo- o fenômeno da informação- já nasceu transdisciplinar, com inúmeros outros campos, destacando-se a Matemática, Física, Biblioteconomia, Comunicação, Linguística, Informática, Sociologia, Psicologia, História, Economia e Administração.

Outra autora que afirma que a CI já nasceu transdisciplinar ${ }^{21}$ é Mueller (2007) a qual, analisando as fontes e os assuntos da área da Ciência da Informação no Brasil, busca perceber as evidências que contribuíram para demonstrar a natureza transdisciplinar da área e conclui que, no momento contemporâneo, a CI parece ser transdisciplinar. É também discordando de que a Ciência da informação é interdisciplinar que Souza, F. (2007) vê:

a interdisciplinaridade da Ciência da Informação como um instrumento para tomada de decisão. [...]. É a Ciência da Informação atuando na porção prática que se deseja encontrar no campo. É por essa via que, nos anos recentes, surgiram projetos ou cursos de graduação, no Brasil, com a designação Ciência ou Gestão da Informação. Neste caso, são propostas curriculares e projetos pedagógicos que competem diretamente com os cursos de Biblioteconomia e Arquivologia já estabelecidos, sobretudo, pelo apelo representado por uma carga de horas-aula maior em informática e gestão. No entanto, não trazem novidade teórica ou epistemológica. Sua configuração tem uma face mais direcionada para a Economia da Informação e, portanto, como conteúdo, representa um recorte contemporâneo à modernização industrial, ou seja, exceto pela propalada inserção das recentes tecnologias de informação, não diferem, epistemologicamente, dos cursos de Biblioteconomia ou Arquivologia ofertados nas últimas décadas. [...]. Vê-se isso no ensino de graduação em Biblioteconomia, com a ideia de que para revitalizar os cursos de Biblioteconomia basta mudar o nome para Ciência da Informação, ou criar com esse

\footnotetext{
${ }^{21}$ Para maiores detalhes sobre as propostas de uma ciência transdisciplinar cf. Freitas; Morin e Nicolescu (1994) e Morin (2011).
} 
nome habilitações. Isso faz com que esse sentido possível da interdisciplinaridade seja de um irreparável dano em termos epistemológicos no contexto brasileiro de ensino e de pesquisa.

Em relação à epistemologia da Biblioteconomia, Mostafa (1989, p. 13, grifo nosso) se expressa da seguinte maneira: “como qualquer outra ciência, a Biblioteconomia se movimenta pelas avenidas do método nas ciências, ou ainda, a trajetória do método nas ciências, é a mesma coisa em todas as áreas, e, sobretudo, nos fará entender a construção epistemológica da Biblioteconomia”. No mesmo sentido, Souza, S. (1986, p. 191) afirma que a Biblioteconomia, entendida aqui como Informatologia, ou Ciência da Informação, é o estudo dos fenômenos ligados à produção, organização, difusão e utilização de informações em todos os campos do saber.

Além dos autores que se apoiam no paradigma físico, há outros que se apoiam no paradigma cognitivo e que tem por preocupação a recuperação do conteúdo dos documentos, preocupação já encontrada em Otlet e La Fontaine; daí, muitos considerarem que a Documentação seria a origem da Ciência da Informação. Já os que se apoiam no paradigma social, acreditam ser a Biblioteconomia clássica a origem da Ciência da Informação. Devido a essas origens da Ciência da Informação, vamos realizar neste momento, a discussão somente sobre a sua gênese apoiada no paradigma físico (cuja origem está pautada no artigo de Vannevar Bush e do seu MEMEX).

Podemos, pois, relacionar o conceito de informação do autor citado, ao conceito de informação de Buckland (1991), para quem a informação é algo tangível relacionado à informação como coisa, mais especificamente, é a informação de que tratam as bibliotecas, arquivos, museus, jornais, dentre outros. Portanto, as áreas atuantes na informação são: biblioteconomia, museoconomia, documentação e jornalismo, cada uma se preocupando com os seus respectivos suportes informacionais (LE COADIC, 1996, p. 20-21). Todavia, para o referido autor, a Ciência da Informação nasceu sob a tríplice influência do desenvolvimento da produção e das necessidades de informação científica e técnica; desenvolvimento de um novo setor industrial das indústrias da informação e do surgimento das tecnologias eletrônicas (analógicas ou digitais) e fotônicas (microcomputadores, disco laser, fibra óticas, etc.) da informação, a saber:

de prática de organização, a ciência da informação tornou-se, portanto, uma ciência social rigorosa que se apoia em uma tecnologia também rigorosa. Tem por objeto o estudo das propriedades gerais da informação (natureza, gênese, efeitos), ou seja, mais precisamente: a análise dos processos de construção, comunicação e uso da 
informação e a concepção dos produtos e sistemas que permitem sua construção, comunicação, armazenamento e uso (LE COADIC, 1996, p. 26).

Outro autor cujas formulações vêm ao encontro de Le Coadic é Wersig (1993, p. 229) para quem a ciência da informação "é um protótipo de ciência pós-moderna, portanto, não é uma ciência clássica, e surge mais pela necessidade de criar estratégias para solucionar problemas causados pela ciência e tecnologia". Ou seja, as práticas das disciplinas que sempre atuaram no campo da informação, a exemplo da Biblioteconomia, estavam bem delimitadas desde o seu surgimento, mesmo que, para alguns, ela não tenha se constituído como ciência, com o seu fazer marcado por métodos e técnicas bem definidas, e que estavam dando conta do volume informacional gerado pela sociedade. Bastante significativa, também, foi a emergência do pragmatismo na aplicação empresarial da recuperação da informação: a indústria informacional ou, para ser mais preciso, o setor que lida com a criação e distribuição de bases de dados e de serviços on line decorrentes, bem como o acesso à informação e sua disseminação. Essa indústria da informação tem suas raízes, diretamente relacionadas, com os trabalhos de recuperação da informação dos anos 50 e 60, que culminaram com a emergência dos serviços on line nos anos 70 e com a viabilização internacional da indústria da informação nos anos 80 (SARACEVIC, 1996, p. 45). Todavia, a partir de um determinado momento, principalmente a partir das TICs e com a abertura do sistema Web para os mais diversos usuários, os quais, a partir dali, poderiam colocar na rede quaisquer tipos de dados, as técnicas de organização e de recuperação de informação já não mais atendiam aos apelos da nova realidade.

É, pois, nesse momento, que a informação (a qual muitos autores afirmam ser o objeto da Ciência da Informação) está cada vez mais presente na sociedade em forma de fluxos disseminados e não mais como algo que estava fixado em determinado lugar (cujo fluxo era uniforme e unidirecional). Hodiernamente, os fluxos informacionais são multiformes, multidirecionais, e a informação pode ser produzida em qualquer lugar pelos sujeitos sociais, podendo ser difundida por meio de diversas mídias para vários outros receptores sem uma direção e uma forma definida. Todavia, não é consenso que o objeto de estudos daquilo que se denomina de Ciência da Informação seja a informação, pois autores como Almeida Júnior (2009, p. 94) afirmam que:

Hoje, a informação é aceita como sendo esse objeto. Para muitos, a informação registrada. Defendemos que esse objeto deva ser reconsiderado e a informação ser trocada pela mediação da informação. Assim, o objeto da CI passaria a ser a 
mediação da informação [e a Ciência da Informação passaria a ser denominada de Ciência da Mediação da Informação].

Concordamos com Almeida Júnior (2009) quando afirma que o objeto da Ciência da Informação não é a informação, pois a informação em si é algo que não existe haja vista ela já nascer mediada, pois ao pensarmos a informação utilizamo-nos da língua, a qual, conforme Floris (1995), é o fator privilegiado da mediação; ao pensarmos a informação há a interferência dos conhecimentos que temos anteriormente, além de haver algo, como afirma Paulo Freire, que media os sujeitos da educação, que tanto pode ser algo concreto - a realidade - quanto abstrato, como um teorema matemático. Ou seja, a informação de que trata a chamada Ciência da Informação, já é mediação. Se tomarmos a informação como sinônimo de significação, todo significado que é atribuído à informação pelos homens já nasce com as categorias de espaço e de tempo a priori; portanto, já nasce mediada pelo espaço, pelo tempo e pelas linguagens pela qual ela é pensada. Na realidade, apoiamo-nos em Ginzburg (1991) em tal afirmação, uma vez que, para este autor a representação é representação de alguma coisa invisível e que se torna visível mediante outra. Foi nesse mesmo pensamento que Shopenhauer afirmara que o mundo só nos é dado como representação, é nesse sentido que para representar (ação de colocar no lugar da coisa) precisamos dos construtos simbólicos. Outro autor que nos leva a pensar que a informação já nasce mediada é Capurro (2007, p. 173) quem afirma que a informação está sempre relacionada a algum tipo de redundância ou ruído.

Portanto, se a informação registrada é tomada como o objeto da CI como alguns autores afirmam, conforme a citação acima de Almeida Júnior (2009), a CI não trataria da informação em si, haja vista a impossibilidade de ela ser pensada, pois o que é a informação? Essa resposta irá variar de acordo com o espaço sociotemporal na qual ela for dada. O que se denomina de informação é mutável conforme as categorias de tempo e espaço social, portanto, informação é uma categoria para o médico, outra para o engenheiro, outra para o bibliotecário e é nesse sentido que afirmamos a impossibilidade de se haver uma ciência "da informação". Corroborando a ideia de que as coisas do mundo já nascem mediadas e que não existe informação em si, Latour (1988 apud SANTAELLA; LEMOS, 2010, p. 38) afirma que "nada é por si mesmo ordenado ou desordenado, único ou múltiplo, homogêneo ou heterogêneo, fluido ou inerte, humano ou não humano, útil ou inútil. Nunca em si mesmo, mas sempre pelos outros".

Nesse sentido, podemos afirmar que o que existe e que seria possível pensar em termos de um objeto científico seria a mediação da informação, haja vista que, quando a 
informação é pensada pelos homens num determinado contexto, ela já nasce mediada pelas categorias a priori de espaço e de tempo. Concordamos, a saber, com Almeida Júnior (2009) quem propõe que o objeto da Ciência da Informação não seja mais tido como a informação, mas que seja a mediação da informação. Portanto, a ciência que estudaria os processos de mediação da informação seria a Ciência da Mediação da Informação.

Se considerarmos o artigo de Vannevar Bush como o marco da gênese da CI e corroborarmos com as palavras de Souza, F. (2007) supracitadas, então, podemos afirmar que ela nasceu num contexto utilitarista, de ciência aplicada para resolver determinados problemas de explosão informacional no contexto do pós-guerra. Mas, também, se considerarmos os nomes de Otlet e La Fontaine como marcos do desenvolvimento da Documentação e que, por conseguinte, contribuiu para a constituição da Ciência da Informação, também encontramos outro contexto de explosão de informações (num período de pós-guerra mundial, em sua primeira versão). Daí, assim como Ortega (2009), acreditarmos que a Biblioteconomia e, em seguida, a Documentação são fases históricas de desenvolvimento da Ciência da Informação que atingiu o sua consolidação no pós-1945 com Bush e seu MEMEX. Portanto, ficamos com Ortega (2009, p. 30), para quem:

\footnotetext{
a celeuma que envolve a questão da identidade da Ciência da Informação não se manifesta de forma relevante na literatura e nas práticas profissionais pautadas na Documentação, a qual tem apresentado, simultaneamente, foco e densidade no decorrer do tempo. A história da Documentação permite questionar os discursos sobre a ausência de consensos em Ciência da Informação e sobre a frágil nuclearidade decorrente de sua dimensão técnica e da suposta fluidez intrínseca aos seus limites e áreas fronteiriças. Conclui que os princípios documentários configuram-se como parte basilar dos fundamentos da Ciência da Informação e são emblemáticos de sua unidade identitária.
}

É no contexto de uma sociedade em rede, a qual, conforme Musso (2004, p. 34) "indica um futuro libertador, é uma promessa de uma circulação generalizada e libertadora dos fluxos de informações e das ondas econômicas", que tanto a Ciência da Informação vem sendo moldada, quanto o perfil dos profissionais da informação, pois, se no contexto da modernidade, esse profissional tem uma identidade sólida, ou seja, conforme Valentim (2002, p. 121) "o profissional da informação é aquele que trabalha em arquivos, bibliotecas e museus" em outro momento, a sua identidade se liquefaz e ele pode atuar em quaisquer outros locais que não sejam apenas a biblioteca, o arquivo e o museu, uma vez que ele é o profissional que, conforme Smit (2000, p. 130) “detecta, organiza, sistematiza, empacota, avalia e disponibiliza a informação". Ou seja, o profissional da informação não possui uma identidade fixa, com as fronteiras bem demarcadas, como os bibliotecários, museólogos e 
arquivistas possuíam na modernidade. No contexto da conceituação de Smit (2000), vários são os profissionais que se encaixariam no predicativo "da informação", dentre os quais, jornalistas, publicitários, contabilistas, administradores, etc. Como não se tem um consenso acerca de quem é, na realidade, esse profissional da informação, percebemos que esses profissionais se encontram em crise de identidade, o que gera um sentimento de insegurança, pois as fronteiras não se encontram demarcadas. Quem é, pois, o cientista da informação? Qual o objeto da Ciência da Informação? Quem são os profissionais da informação? Estas são questões de uma área em que, nem mesmo o seu objeto de estudos tem uma conceituação precisa, pois esse objeto seria a informação ou a mediação da informação? E o que seria a mediação da informação? Essas e outras questões identitárias e que geram respostas incertas, fragmentadas, permeiam as ciências que se gestaram e as que vêm se gestando (como a Ciência da [Mediação] [da] Informação) no período contemporâneo.

\subsection{Mediação, tecnologia e a formação em CI}

Neste momento, abordamos os vários olhares sobre o conceito de mediação, incluindo o olhar da Ciência da Informação, além de tentarmos perceber como a literatura aborda as transformações dos processos mediacionais com a inserção das tecnologias nesses processos, para, em seguida, tratar da formação de bibliotecários no contexto da contemporaneidade em que a identidade desse profissional vêm se "liquefazendo", tomando de empréstimo a expressão de Bauman.

Além das questões identitárias e epistemológicas, já abordadas anteriormente, temos a questão do imperativo tecnológico. Ou seja, no mundo contemporâneo não podemos abrir mão, nem dos avanços científicos, nem das tecnologias; todavia, o desafio é conferir novos horizontes a eles, fundamentados na criticidade. É decisivo utilizar as tecnologias midiáticas nos processos de emancipação humana, ou seja, torna-se urgente a apropriação das ciências e das tecnologias na perspectiva de superação do tecnicismo, da espetacularização, da mercantilização. É, pois, este o enigma e o desafio apresentado pela "esfinge de Édipo" à Ciência da Informação e aos seus profissionais, enigma este que vai desaguar na formação do bibliotecário na contemporaneidade. Se não há consenso acerca do que seria a CI, nem o seu objeto (se a informação ou se a mediação da informação), também não há consenso sobre em que deveria se centrar a prática e a formação do bibliotecário, se nos processos organizacionais, ou mediacionais. Mas, o que seria mediação? Tem como visualizar de forma 
separada os processos mediacionais e os organizacionais no que se refere à informação? Qual a importância da mediação da informação nesse novo contexto societário?

Tendo em vistas que, no contexto deste estudo, pretendemos analisar o papel da mediação na estruturação dos currículos de formação do bibliotecário brasileiro, buscamos, portanto, entender o que significa a mediação para a área da Biblioteconomia e da Ciência da Informação. No entanto, mesmo tentando compreender o que seria esse conceito para as áreas em lide, como não poderia deixar de ser, fomos buscar na filosofia as bases de sua compreensão.

O conceito de mediação é oriundo do latim mediare que significa estar no meio, se interpor. Em nossas primeiras buscas acerca do conceito no campo da Filosofia encontramos o dicionário de Zarader (2007, p. 365) o qual afirma que a primeira formalização do conceito de mediação foi realizada por Aristóteles em seu Organon e significava as diferentes relações lógicas que são possíveis entre proposições distintas, designadas sob o termo de silogismo. A primeira proposição e a conclusão seriam mediatizadas pela segunda, que é o meio-termo, o qual instaura um laço de implicação lá, onde as duas proposições parecem independentes. Portanto, a partir das duas primeiras proposições, denominadas de premissas, pode-se deduzir uma conclusão, o que nos leva a intuir que a primeira conceitualização do termo mediação já partiu do âmbito da linguagem humana, do seu discurso.

Do âmbito da filosofia e do discurso, partiremos para o âmbito das ciências sociais e das relações/comunicações humanas e, nesse contexto, encontramos Lamizet e Silem (1967, p. 364) para quem a mediação seria uma instância que assegura, na comunicação e na vida social, a articulação entre a dimensão individual do sujeito e de sua singularidade e a dimensão coletiva da sociabilidade e do elo social. Nesse sentido, as mediações são a linguagem e os símbolos, pois eles asseguram, no curso do uso que é feito pelos sujeitos, a apropriação singular dos códigos coletivos. As mídias e as outras formas sociais da comunicação são mediações, pois elas asseguram, no espaço público, a apropriação singular, pelos leitores ou seus usuários de uma forma geral, de informações que constituem a cultura coletiva característica de uma identidade, de um grupo social, ou de um país, num determinado momento de sua história. Se as mídias asseguram essa identidade coletiva por meio das mediações que ela assegura, então a identidade seria uma mediação essencial da relação entre o espaço e a sociedade; ou seja, conforme as ideias de Di Méo (2002, p. 178), o território recontaria a inserção dos indivíduos num grupo e isso construiria a sua pertença, a sua identidade coletiva. Por meio da nossa pertença aos lugares, aos espaços geográficos, o 
nosso relacionamento com os outros é mediado. Essa mediação é traduzida por meio do trabalho, do lazer, da consumação, da vida associativa e esportiva, das festas, etc.

A partir das considerações acima efetuadas, podemos afirmar, portanto, que são três os tipos de mediação fixados por Lamizet e Silem (1967), a saber: 1) a língua, 2) o espaço social e 3) as instituições e as estratégias de comunicação (que são formas de mediação e de comunicação), que vamos tratar nas discussões a seguir.

A primeira forma de mediação do homem consigo mesmo e com o mundo foi realizada por meio da interação face a face. Portanto, a língua e o espaço social foram os primeiros mediadores. Para Rodrigues (2000, p. 84) mediação é o "processo de interlocução ou de interação entre os membros de uma comunidade, pelo qual se estabelece, alimentam ou restabelecem laços de sociabilidade, constituindo, assim, o mundo da vida. A linguagem e a ação comum são os fatores privilegiados de mediação.” Entendendo a língua conforme os postulados de Saussure, ou seja, como um conjunto de sinal (implica reação por parte do usuário), símbolo (total ou parcialmente inconsciente) e signo (conscientemente apreendido e usado), podemos afirmar que a mediação sempre esteve presente no mundo, desde os tempos mais remotos. Portanto, a noção de mediação está relacionada, primeiramente, à ideia de interação face a face, pois desde quando o primeiro homem realizou o primeiro gesto a fim de comunicar alguma informação a outro, ele já estava realizando um processo de mediação da informação e da própria cultura. Pensemos, por exemplo, quando o recém-nascido mantém o primeiro contato com a mãe, por meio da amamentação, ambos já estão se comunicando, já existe, portanto, um ato de reconhecimento do recém-nascido com o mundo que lhe é exterior.

Com a linguagem (vista sob a abordagem saussuriana), as relações humanas foram se organizando e o real passou a ser representado simbolicamente. A língua é um meio de comunicação que permite nomear e fazer existir as coisas no mundo e um autor que vem ao encontro dessa ideia de que a língua foi o primeiro fator privilegiado de mediação é Floris (1995, p. 152-153), para quem a comunicação é a mediação potencial do relacionamento entre os homens nas suas formas de organização e de linguagem num meio objetivado. A forma de organização é o modo objetivo dos relacionamentos entre os homens e a linguagem é seu modo subjetivo e essas duas formas traduzem a dupla forma objetiva e subjetiva dos relacionamentos sociais.

Outra forma de mediação cultural é o próprio espaço social, no qual se organizam e se estruturam as expressões de pertença das quais os atores se reclamam no espaço social. Aquilo que percebemos no espaço social, que foi modificado pelo homem, faz parte de sua cultura, produzindo aquilo que Floris (1995) denomina de mediações sociais, ou seja, 
processos de interpenetração e de trocas mútuas de diferentes formas de organização social dos homens uns com os outros.

O espaço é representação cultural, pois ele media cultura. Se viajo e vou até a Índia, o próprio espaço me comunica a cultura daquele lugar, por meio de sua arquitetura, da organização do espaço, etc. Corroborando, Lamizet (2004) define mediação cultural como uma representação estética das formas de identidade, é a identidade dos sujeitos singulares, que se exprime nas suas práticas culturais (espetáculos, artes, etc.) ou daquela dos atores coletivos e das instituições, que se exprime nas políticas culturais, no desenvolvimento do espaço estético ou nas formas coletivas da representação. A mediação cultural constitui, assim, uma mediação, exprimindo a identidade dos atores da sociabilidade deixando-a inteligível e colocando-a numa lógica de sublimação estética. Acerca do conceito de mediação cultural, Montoya (2008, p. 25, tradução nossa) afirma que:

\begin{abstract}
A noção de "mediação cultural" recobre na França uma definição particular, ligada à história das políticas e das empresas de democratização cultural francesas. Nesse setor, ela designa, na sua acepção mais larga, o conjunto das modalidades de colocar em relação, a produção artística com os públicos.
\end{abstract}

Percebemos que o conceito de mediação pode ser abordado nas dimensões: política, social, institucional e, atualmente, dentro das mediações institucionais, podemos tratar dos efeitos das TICs, tanto nas empresas como nas redes sociais. Todavia, é importante lembrar que as práticas de mediação não podem ser tratadas como novidades, pois as mesmas vêm fazendo parte do mundo desde os tempos mais remotos. Nas mediações institucionais, a prática da mediação por meio da língua também está presente, pois são as instituições, tais como a família, a escola, etc. que repassam para o indivíduo o contato com os signos linguísticos. Nesse ínterim, Floris (1995, p. 153) afirma que "a linguagem não é apenas o meio, ela é a série de todas essas mediações objetivas e subjetivas".

Se Lamizet e Silem (1967) propõem três tipos de mediação, por outro lado, encontramos os escritos de Jouët (1993, p. 101) para quem as práticas de comunicação são elaboradas em torno de uma dupla mediação, pois a mediação se apresenta tanto na forma técnica, uma vez que a ferramenta utilizada estrutura a prática comunicacional, mas também, se apresenta na forma social, pois os dispositivos, as suas formas de uso e o sentido acordado na prática são recursos do corpo social. Para Jouët (1993), a mediação da técnica não é neutra na elaboração das práticas de comunicação e as mídias interativas marcam uma ruptura nos 
modelos de uso das mídias de massa e, portanto, se caracterizam por uma forte individualização das práticas.

Antes do advento das TICs predominava a mediação através da interação face a face; contudo, a partir da segunda metade do século XV, novos meios informativos e comunicativos surgem, como por exemplo, a invenção da imprensa, os jornais, o rádio, o telefone etc., fazendo aparecer novas formas de sociabilidade, sem a necessidade de haver uma presença física. Essas novas mídias vêm ocasionando profundas transformações nas formas de interação humana e, por consequência, das mediações. Desta feita, Thompson (2002) classifica três tipos de situação interativa criados pelos meios de comunicação: “interação face a face", "interação mediada" e "quase-interação mediada".

$\mathrm{Na}$ interação face-a-face o fluxo de comunicação tem mão-dupla: uma pessoa fala, a outra responde, e assim por diante, ou seja, ambos são emissores e receptores de informação. Terry Eagleton (1998, p. 76), contrariando a perspectiva de que a fala seria o primeiro fator de interação, afirma que seria "o corpo o sinal mais palpável dessa intermediação- talvez mais que a linguagem, que também constitui uma atividade dos seres da nossa espécie, mas que parece muito mais do lado da cultura". Ou seja, mesmo antes do desenvolvimento da linguagem humana o homem já se comunicava por meio dos gestos, dos sons emitidos, portanto, sua primeira forma de mediação foi por meio do corpo. Para ocorrer a interação face a face os indivíduos têm, necessariamente, que estar no mesmo espaço/tempo da comunicação. Nesse tipo de interação, o fluxo de informação tem duas direções (Quadro 2), quer seja de ida e de volta, é dialógico; a saber, tem o feedback de informações e o fluxo da informação não aponta numa determinada direção, mas se apresenta de forma circular.

Quadro 2- Demonstração dos fluxos de informações da interação face a face (à esquerda), da interação mediada (ao meio) e da quase-interação mediada (à direita).

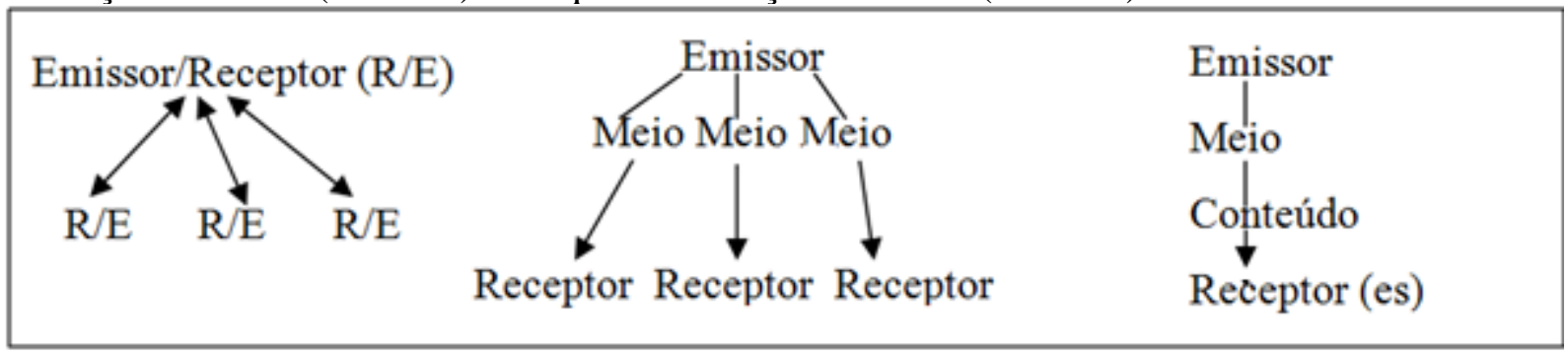

Fonte: Elaborado pela autora.

Segundo John Thompson (2002), o intercâmbio de informação e o conteúdo simbólico sofrem uma profunda mudança com as inovações tecnológicas (imprensa e, posteriormente, meios eletrônicos): as interações face a face cedem cada vez mais espaço para 
as interações mediadas e as quase-interações mediadas - as relações que as pessoas estabelecem com os conteúdos dos meios. Para ele, as pessoas passam a considerar cada vez mais outras fontes de informação, além das pessoas com as quais interagem diretamente no cotidiano: "a criação e a renovação das tradições são processos que se tornam sempre mais interligados ao intercâmbio simbólico mediado" (THOMPSON, 2002, p. 82).

Na modernidade, os processos de mediação da informação foram sendo alterados pari passu ao desenvolvimento das mídias. Se num determinado momento da história, a troca de formas simbólicas era efetuada em contextos de interação face a face, nos últimos tempos, essas trocas passam a ser mediada pelos novos aparelhos midiáticos. Portanto, concordamos com Akrich (1993, p. 89) quando afirma que "o desenvolvimento das sociedades modernas é acompanhado de um declínio dessas diferentes formas de mediação em proveito de uma só dentre elas, a mediação técnica".

$\mathrm{Na}$ interação mediada está implicado o uso de um meio técnico (papel, fios elétricos, ondas eletromagnéticas) que possibilitam a transmissão da informação e conteúdo simbólico para indivíduos situados remotamente no espaço, no tempo, ou em ambos. As interações mediadas fornecem aos participantes poucos dispositivos simbólicos para a redução da ambiguidade na comunicação. Por isso, as interações mediadas têm um caráter mais aberto do que as interações face-a-face. Estreitando as possibilidades de deixas simbólicas, os indivíduos têm de se valer de seus próprios recursos para interpretar as mensagens transmitidas (THOMPSON, 2002, p. 79). Para que haja interação mediada é necessário o uso de um meio técnico, quais sejam: papel, fio elétrico, ondas eletromagnéticas, etc. que permita a transmissão da informação e conteúdo simbólico para indivíduos independentemente do espaço/tempo em que ele se encontra inserido. Este tipo de interação difere-se da interação face-a-face na medida em que esta não necessita da presença física das personagens do processo comunicacional.

Na quase-interação mediada, o fluxo da informação tem sentido único, ou seja, o leitor de um livro, o ouvinte de um rádio recebe a forma simbólica, mas não exige uma resposta direta e imediata, pois ele interage com o conteúdo do meio. Por isso, ela é definida como quase-interação. Nela, as formas simbólicas são produzidas para um número indefinido de receptores potenciais. Para Thompson $(2002$, p. 79) esse tipo de interação são aquelas "relações sociais estabelecidas pelos meios de comunicação de massa (livros, jornais, rádio, televisão, etc.)". Ou seja, a quase-interação mediada é aquela que os homens estabelecem com os conteúdos dos meios, portanto, ela não tem um receptor-alvo, mas vários receptores e não precisa de um feedback do receptor, daí o fato de ela ser denominada de quase-interação. O 
receptor não é um ser específico, mas vários seres, independentemente de suas características, quer sejam pessoais ou sociais. O fluxo da informação, numa quase-interação mediada, tem sentido único.

Os meios de comunicação de massa ampliam a acessibilidade das formas simbólicas no tempo e no espaço, e fazem isso de uma maneira que permite tipos específicos de interação mediada entre produtores e receptores. Sendo que a comunicação de massa institui uma ruptura fundamental entre a produção e a recepção das formas simbólicas, ela torna possível um tipo particular de interação através do tempo e do espaço que pode ser descrito como uma quase-interação mediada. Portanto, esse tipo de comunicação é quaseinteração porque o fluxo da comunicação é predominantemente de mão única, e os modos de resposta através dos quais os receptores podem se comunicar com o comunicador principal são estritamente limitados (THOMPSON, 2000, p. 299).

A organização social da "interação quase mediada" é uma maneira de interpretar o processo de institucionalização da informação com o objetivo de garantir a construção e reprodução do conhecimento considerado socialmente relevante. Estabelece-se uma relação entre instituições e papéis sociais, e a adequação do comportamento a estruturas previamente definidas. Os processos de mediação cultural e da informação podem ser vistos, portanto, como estratégicos para a atuação dos profissionais da informação no presente contexto (ALMEIDA, M., 2008). Portanto, relativizamos quando Thompson (2000) afirma que o fluxo da informação numa quase-interação mediada tem sentido único, pois, se o receptor interage com os conteúdos dos meios, ele pode ser receptor, mas também, com as novas tecnologias interacionistas, ele pode ser autor, reeditando os conteúdos. É o que acontece, por exemplo, com a Wikipédia em que todos são autores (emissores) e receptores.

É importante observar que os três tipos de interação (Quadro 3) não são excludentes entre si, ou seja, eles podem ocorrer concomitantemente, pois, por exemplo, um professor pode estar em sala de aula apresentando o conteúdo de um slide, enquanto os alunos interagem com ele verbalmente (interação face a face), fazendo perguntas e, ao mesmo tempo, o professor respondendo. Eles também podem estar discutindo os conteúdos dos livros, momento em que ocorre uma quase-interação mediada. Interessante observar que nas quaseinterações mediadas, as deixas simbólicas, tais como aquelas associadas ao olfato e ao tato não podem ser transmitidas. Outra limitação das interações quase-mediadas é em relação ao feedback, uma vez que esse tipo de interação não possibilita o feedback imediato para o receptor da informação. 
Quadro 3- Características dos tipos de interação comunicacionais

\begin{tabular}{|c|c|c|c|}
\hline $\begin{array}{l}\text { Características } \\
\text { Interativas }\end{array}$ & $\begin{array}{l}\text { Interação } \\
\text { Face a face }\end{array}$ & Interação mediada & $\begin{array}{l}\text { Quase-interação } \\
\text { mediada }\end{array}$ \\
\hline Espaço-tempo & $\begin{array}{l}\text { Contexto de co- } \\
\text { presença; } \\
\text { referencial espaça- } \\
\text { temporal comum }\end{array}$ & $\begin{array}{l}\text { Separação dos } \\
\text { contextos; } \\
\text { disponibilidade } \\
\text { estendida no tempo e } \\
\text { no espaço }\end{array}$ & $\begin{array}{l}\text { Separação dos contextos; } \\
\text { disponibilidade } \\
\text { estendida no tempo e no } \\
\text { espaço }\end{array}$ \\
\hline $\begin{array}{l}\text { Possibilidades } \\
\text { de deixas } \\
\text { simbólicas }\end{array}$ & $\begin{array}{ll}\text { Multiplicidade } & \text { de } \\
\text { deixas simbólicas } & \end{array}$ & $\begin{array}{lr}\text { Limitação } & \text { das } \\
\text { possibilidades } & \text { de } \\
\text { deixas simbólicas } & \end{array}$ & $\begin{array}{l}\text { Limitação } \\
\text { possibilidades de deixas } \\
\text { simbólicas }\end{array}$ \\
\hline $\begin{array}{l}\text { Orientação da } \\
\text { atividade }\end{array}$ & $\begin{array}{l}\text { Orientada para outros } \\
\text { específicos }\end{array}$ & $\begin{array}{l}\text { Orientada para outros } \\
\text { específicos }\end{array}$ & $\begin{array}{l}\text { Orientada para um } \\
\text { número indefinido de } \\
\text { receptores potenciais }\end{array}$ \\
\hline $\begin{array}{l}\text { Dialógica/ } \\
\text { monológica }\end{array}$ & $\mathrm{Di}$ & $\mathrm{Di}$ & Monológica \\
\hline
\end{tabular}

Fonte: THOMPSON (2002, p. 80).

$\mathrm{Na}$ contemporaneidade, estamos cada vez mais midiatizados pelas várias Tecnologias de Informação e de Comunicação de que dispomos, tecnologias estas que vêm provocando o reordenamento do tempo e do espaço da comunicação de informações. Muitos denominam esse processo de globalização econômica, mesmo reconhecendo que os processos de globalização possam remontar ao século XVII com as primeiras formas de telégrafo, ou até mesmo ao século XV, com as grandes navegações, portanto,

embora as origens da globalização da comunicação possam remontar ao século XIX, este processo é, entretanto, tipicamente um fenômeno do século XX. Pois foi durante este século que o fluxo de comunicação e informação em escala global se tornou uma característica regular e penetrante na vida social (THOMPSON, 2002, p. 143).

Com o surgimento da comunicação de massa, o processo de transmissão cultural, torna-se cada vez mais mediado por um conjunto de instituições interessadas na mercantilização e circulação ampliada das formas simbólicas (THOMPSON, 2000, p. 278). Com o desenvolvimento das TICs o mundo parece cada vez mais próximo de uma aldeia global, conforme expressões de McLuhan. O desenvolvimento dos sistemas de cabo para a transmissão eletrônica da informação codificada, o uso de satélites para comunicação a longa distância e o uso de métodos digitais aumentou de forma bastante intensa o volume de informações processadas, armazenadas e recuperadas. Em virtude do distanciamento espaçotemporal, o desenvolvimento dos meios técnicos separa a interação social do local físico, de 
tal maneira que as pessoas podem interagir umas com as outras mesmo que elas não partilhem uma situação espaço-temporal comum.

Continuando nessa perspectiva mais técnico-humanista acerca das mediações, traçaremos um diálogo com Miège (2009), o qual, num sentido mais próximo a Castells (2010) afirma que a Internet seria a nova infraestrutura da sociedade, afirmando que esta vai se disseminar alhures, por meio das TICs e das conexões wi-fi e, também, por meio das nanotecnologias e, portanto, este fato constituiria uma nova era denominada de "tecnológica e biométrica”. Portanto, o referido autor afirma que, devido ao fato de não ser possível separar essas tecnologias da contemporaneidade do fator social e das mais variadas mediações que são estabelecidas entre ambos, dever-se-ia qualificar essas tecnologias como sociotécnicas, termo este que inclui as ferramentas, os dispositivos e os serviços associados, bem como os processos inovativos (MIÈGE, 2009, p. 26).

Numa perspectiva mais propriamente social acerca dos processos de mediação, encontramos Jean Caune, para quem a mediação pode ser examinada como um conjunto de práticas sociais que se desenvolvem em domínios institucionais diferentes e que visam a construir um espaço determinado e legitimado pelas relações que se manifestam nela (CAUNE, 2000). A partir deste conceito de Jean Caune, percebemos que, por mais que o conceito de mediação seja plástico, talvez devido à sua maior utilização mais contemporaneamente, ele pode vir a ser uma forma de recusa a certas práticas da sociedade dita pós-moderna, caso as práticas mediacionais forem realizadas numa perspectiva mais vinculada à perspectiva proposta por este autor, ou seja, realizar projetos sociais com vistas a buscar relações e ações mais duradouras na sociedade.

Em relação ao autor em lide, Rasse (2000) afirma que ele amplia a mediação para a história individual e coletiva, que religa os homens às gerações passadas, através da herança, do patrimônio, e lhes permite se projetarem para o porvir. Nesse contexto, Rasse (2000) afirma que o conceito de mediação de Caune (2000) recobre a ideia de cultura no sentido antropológico do termo e é ela que religa os homens entre si, para dar sentido à sua existência pessoal, portanto, a mediação não é um conceito, uma teoria organizada, relativamente solidificada e pronta para ser empregada para analisar o espaço social; ela recobre, ao contrário, um campo de debate teórico e de práticas profissionais sobre as relações entre a cultura e seu público. Ela é esse espaço de comunicação onde se tecem os elos dos visitantes com os museus e o patrimônio, dos espectadores com o teatro, dos ouvintes com a música (RASSE, 2000). 
Numa outra perspectiva encontramos Miège (2009, p. 38) o qual afirma que para Jean Caune as nanos, a biologia, a informática e as ciências cognitivas se dão como missão a realização de uma nova era, ao se reativarem dois dos grandes mitos da modernidade: o mito do saber todo poderoso, e o mito de Golem, ou seja, da criatura criada à imagem e semelhança de Deus. Acrescentando, Rasse (2000) afirma que a mediação é também trabalho, práticas profissionais, técnicas e saber-fazeres.

Na contemporaneidade, conforme Featherstone (1995, p. 132) “o processo de globalização contribui, nesse aspecto, para fortalecer o papel dos intermediários culturais, que administram as cadeias de distribuição da nova mídia global (via satélite, etc.)”. Ou seja, são cada vez mais presentes as atividades dos mediadores culturais, pois são eles quem decide que atividade será, ou não, realizada em determinados contextos. Ou seja, a mediação cultural:

Pode ser definida, sem dúvida, a nível funcional: visa fazer aceder um público a
obras (ou saberes) e a sua acção consiste em construir uma interface entre esses dois
universos estranhos um ao outro (o do público e o, digamos, do objecto cultural)
com o fim precisamente de permitir uma apropriação do segundo pelo primeiro.
Mas, na prática, ela não deixa de cobrir coisas tão diversas como a prática
profissional dos mediadores (de museu ou de património, por exemplo); uma forma
de aç̧ão cultural por oposição à animação cultural; a construção de uma relação
com a arte; produtos destinados a apresentar ou a explicar a arte ao público; etc.
(DAVALLON, 2007, p. 4).

Para Caune (2000) a noção filosófica de mediação, que caracteriza as relações entre o sujeito e o mundo, está a um passo de se tornar um conceito de marketing, capaz de fixar o transitório, o fugitivo, o contingente, mas que arrisca esquecer o que funda a natureza do elo social: uma transcendência e uma forma simbólica. Portanto, a mediação poderia ser entendida como um conjunto de práticas sociais que se desenvolvem em domínios institucionais diferentes e que visam construir um espaço determinado e legitimado pelas relações que se manifestam. Entendida desta forma, as instituições como a escola, as mídias ou as empresas culturais, podem ser analisadas em função das relações interpessoais que autorizam.

Outro autor que se debruçou na problemática da mediação da cultura e da informação e que vem ao encontro do pensamento de Rasse (2000), Davallon (2007) e Caune (2000) é Almeida, M. (2008), para quem a perspectiva da mediação se generalizou, atribuindo-se o papel de mediador ao "profissional da informação" (seja ele denominado bibliotecário, arquivista, museólogo ou outra definição profissional). Por outro lado: 


\begin{abstract}
A ideia de mediação acaba por cobrir coisas tão diferentes entre si, que vão das velhas concepções de "atendimento ao usuário" à atividade de um agente cultural em uma dada instituição - museu, biblioteca, arquivo, centro cultural -, à construção de produtos destinados a introduzir o público num determinado universo de informações e vivências (arte, educação, ecologia, por exemplo), à elaboração de políticas de capacitação ou de acesso às tecnologias de informação e comunicação, etc. Desse modo, uma definição consensual de mediação parece impraticável: sempre contextualizada, torna-se um conceito plástico que estende suas fronteiras para dar conta de realidades muito diferentes entre si (ALMEIDA, M. 2008, p. 3).
\end{abstract}

Um autor que utilizou e analisou o conceito de mediação em relação à Biblioteconomia e à Ciência da Informação, foi Almeida Júnior (2009, p. 92) o qual afirma que a mediação da informação é "toda ação de interferência - realizada pelo profissional da informação -, direta ou indireta; consciente ou inconsciente; singular ou plural; individual ou coletiva; que propicia a apropriação de informação que satisfaça, plena ou parcialmente, uma necessidade informacional”. Nesta conceituação de Almeida Júnior (2009) ainda está presente a figura do intermediário da informação, mas, e quando esse intermediário não existe? É nesse sentido que Lévy (2000, apud SILVA; LOPES, 2011) fala de desintermediação da informação, ou seja, é um processo de busca de informação em que não se encontra mais a figura do intermediário e a informação chega ao usuário sem passar por uma espécie de “filtro". Portanto, as discussões acerca dos processos de desintermediação da informação e de cultura ainda são bastante incipientes, haja vista nem mesmo os processos de mediação se encontrarem bem delineados para os mediadores. Esses processos de desintermediação da informação são recentes e parecem ser tendências na contemporaneidade, haja vista cada um ser autor e receptor de seu próprio texto. Os usuários da informação são seres cada vez mais autônomos e é devido a esse fato que surgiram os processos de desintermediação da informação e, nesse sentido, Gellman (1996 apud FOURIE, 2001, p. 269) afirma que:

\footnotetext{
a desintermediação é entendida como a busca de informação por um usuário final sem a necessidade de envolvimentos de terceiros: mediadores ou intermediários. Significa a eliminação do mediador entre a informação (ou qualquer produto) e seus usuários finais o que, consequentemente, acarreta o que o autor denomina de potencialização dos usuários. Quando aplicado às unidades de informação (bibliotecas), o termo significa a evolução do acesso à informação que se dava através de depósitos físicos centralizados para as fontes alternativas acessíveis diretamente através de ordenadores e redes de informação.
}

Por outro lado vale lembrar que esse processo de "desintermediação" da informação não é tão simples como parece - baseia-se numa série de programas e serviços disponibilizados on line que, por sua vez, são construtos humanos baseados em determinados valores e interesses. 
Portanto, encontramos não apenas formas de se conceituar mediação que, por mais diferentes que fossem, tinham um ponto de chegada em comum; pelo contrário, as várias conceituações privilegiavam um ou outro aspecto da mediação. Percebendo isso, Davallon (2007) afirma que o exame dos textos das ciências da informação e da comunicação permite distinguir três tipos de utilização do termo mediação: 1) por meio de referências, de forma incidental; 2) como conceito operatório e 3) consagrando uma parte da obra ao termo e visando dar-lhe uma definição.

Para finalizar nossas discussões acerca do conceito de mediação, traçamos um diálogo com o educador Paulo Freire, expoente no campo da educação em relação aos processos de mediação, mais especificamente, de mediação educacional, em seus diversos escritos acerca de educação popular. Para Paulo Freire, o mediador entre o educador e o educando é a realidade em si, tendo em vista que os indivíduos devem se apropriar de sua realidade como forma de inserir-se nela, mas não de forma a ficar aderido, mas imerso nessa realidade para emergir dela com vistas a modificá-la. Portanto, a realidade mediando os sujeitos da educação (educadores e educandos) foi, também, objeto de seus estudos (FREIRE, 2005). Daí, a importância de se conhecer a realidade na qual se está inserido. Este conceito de mediação de Freire (2005) vai ao encontro do conceito de Floris (1995) supracitado, para quem as mediações sociais são os processos de interpenetração e de trocas mútuas de diferentes formas de organização social dos homens uns com os outros.

No âmbito da educação apoiamo-nos no conceito de mediação de Paulo Freire (1983) o qual se refere não apenas à transferência de informação, mas sim, a algo que mediatiza os sujeitos da educação e este "algo" pode ser tanto um fato concreto (a semeadura e suas técnicas, por exemplo), como um teorema matemático. Em ambos os casos, a comunicação verdadeira não nos parece estar na exclusiva transferência ou transmissão do conhecimento de um sujeito a outro, mas em sua coparticipação no ato de compreender a significação do significado, ou seja, de se apropriar dos conhecimentos.

O conceito de mediação de Paulo Freire tem uma abordagem crítica, ou seja, não vê a mediação como algo neutro, mas sim, como um ato de desvelamento da realidade que também não é neutra. Os sujeitos da educação devem estar inseridos nessa realidade a fim de que, conhecendo-a, possam vir a transformá-la. É esta a proposta de Paulo Freire para os profissionais que trabalham com mediação de informações e de cultura, a saber, professores, bibliotecários, portanto, os trabalhadores que atuam em instituições culturais, para abarcar a conceituação de Almeida M. (2008). Ou seja, que esses profissionais tenham consciência de que o trabalho de mediação não é neutro e, que, para terem essa consciência, os mediadores 
devem estar inseridos na realidade de forma crítica. Para tanto, haverá uma mudança de postura na figura do educador, ou seja, ele além de educar, vai educar-se também, crescendo junto com os educandos, portanto:

Já que ninguém educa ninguém, como tampouco ninguém se educa a si mesmo: os homens se educam em comunhão mediatizados pelo mundo. Mediatizados pelos objetos cognoscíveis que, na prática "bancária", são possuídos pelo educador que os descreve ou os deposita nos educandos passivos (FREIRE, 2005, p. 79).

Assim, a realidade dos sujeitos é que servirá de meio para os processos educativos, é o colocar-se nessa realidade, é debruçar-se sobre ela a fim de perceber a linguagem dos educandos para que possa haver comunicação e transformação da realidade e não apenas manutenção do status quo (FREIRE, 2005). Fincando-nos no pensamento do autor em lide, acreditamos que é este papel de mediador que também deve ter o bibliotecário, mas não de mediador que atua de forma isolada, mas sim, de um profissional que está inserido na realidade mesma, como forma de entendê-la e que, por meio de sua prática, ajude a transformá-la.

A prática do bibliotecário enquanto mediador deveria se pautar no conhecimento da comunidade a qual atua, para que os códigos que ele utiliza para organizar a informação possam dialogar com essa mesma comunidade e que se torne uma "ordem informacional dialógica", conforme propõe Pieruccini (2004). Claro que não podemos abrir mão dos conhecimentos que herdamos por meio da tradição, conforme nos apontou Hannah Arendt (2009), mas a grande questão é que, na contemporaneidade, a maioria das técnicas de tratamento, organização, recuperação e mediação da informação davam conta de determinada realidade na Biblioteconomia e, muitas vezes, não se aplica ao atual contexto informacional.

Na contemporaneidade, os acervos não são mais apenas fixos, imóveis, sólidos como no início da modernidade, mas sim, são acervos que também são líquidos - para utilizar expressões de Bauman (2005) - e estão pautados hodiernamente na informação, que tem natureza dual, ora pode ser onda (imaterial), ora pode ser partícula (material). Em decorrência deste fato, percebe-se a necessidade de se encontrar novas formas de organização que possam dialogar e até mesmo utilizar a linguagem dos usuários, todavia, sem abrir mão das linguagens documentárias já existentes. Ou seja, como nos aponta Pieruccini (2004, p. 92), o bibliotecário deve buscar:

Desenvolver, assim, novas formas de modulação da linguagem documentária clássica, representada pela CDD [Classificação Decimal de Dewey], num diálogo 
cuja característica é a recriação da tradição da área, que sinaliza para a necessidade de novos modos de organização documentária, caracterizados pela "abertura", pela flexibilidade e diversidade, pelo jogo entre a estabilidade da língua e a dinâmica do discurso.

Uma ordem informacional onde não mais imperassem apenas as técnicas biblioteconômicas do período moderno, nem técnicas de organização de informação mais contemporâneas, como folksonomias, tag's e outras, mas sim, numa síntese entre as duas formas, que, em sua essência, se propusesse dialógica. Ou seja, é necessário que se encontre uma teoria maior, que a exemplo da física ${ }^{22}$ contemporânea, procurasse novas formas de diálogo entre o acervo, o usuário e o próprio bibliotecário, e que, provavelmente, já nos tenha indicado Pieruccini (2007, p. 8):

\begin{abstract}
Assim, tendo em vista compatibilizar a natureza "fechada" das linguagens documentárias clássicas às propostas de uma ordem informacional dialógica, a constituição da linguagem informacional implicou reconfigurar padrões existentes, introduzindo elementos, aplicando novas sintaxes aos dados da linguagem documentária utilizada, tendo em vista torná-las mais inteligíveis, comunicáveis e, ao mesmo tempo, "abertas" a demandas decorrentes de situações educacionais específicas. Desse modo, a construção da linguagem informacional do dispositivo dialógico foi pautada por critério articulando tanto padrões universais da linguagem documentária, quanto "locais", específicos, sem imposição de uma dimensão sobre a outra, mas, ao contrário, buscando sua complementação, comunicação, diálogo.
\end{abstract}

Esta ideia de Pieruccini (2007) vem ao encontro das ideias de Freire (1967) no seu Educação como Prática da Liberdade, pois este afirma que só existe saber na invenção e na reinvenção e que os conhecimentos não se encontram prontos, acabados, assim como os seres humanos. Tanto os saberes, quanto os homens têm de ter uma vocação do ser-mais, ou seja, de serem conscientes de seu inacabamento e que estão em constantes processos de criação e de recriação. Portanto, a educação a ser praticada, independentemente se ao nível fundamental, médio, ou superior, deve buscar a criação e a recriação dos conhecimentos, até

\footnotetext{
${ }^{22}$ Esta ideia de unir as duas teorias vem ao encontro da física quântica, pois, se com Newton, a Física era pautada numa concepção mecanicista da natureza, sendo o tempo uma categoria imutável e que fluía uniformemente do passado para o futuro e a matéria era constituída de elementos sólidos, indivisíveis e indestrutíveis; com Einstein, o universo passa a ser um todo dinâmico, divisível e inter-relacionado, constituído de átomos que, por sua vez, são constituídos entre outros de elétrons (que ora são partículas, ora são ondas). Na contemporaneidade, a Física se baseia na mecânica quântica de Newton e na relatividade de Einstein. Há momentos em que as duas teorias juntas explicam o universo, mas as duas equações juntas não fazem sentido. Daí as pesquisas com aceleradores de partículas, que visam desvendar a estrutura da matéria e encontrar uma teoria maior que abarque todas as complexidades do universo. Nesse sentido, Souza, F. (2007) na análise acerca da CI, pergunta: a CI, como uma ciência, é de natureza newtoniana, parte de um universo cósmico, obedecendo ao princípio de causa e efeito, dotada de leis e teorias? Ou a CI é de natureza einsteniana, parte de um universo subatômico, obedecendo às relações onda-partícula que se relativizam em função de fatores ambientais que condicionam o fenômeno, ou objeto, sob exame, sem leis e sem teorias da mesma ordem anterior?
} 
mesmo aqueles já consolidados, como no caso da Biblioteconomia e da Ciência da Informação, em relação às linguagens documentárias. Ou seja, as linguagens documentárias existentes, que são mecanismos que buscam favorecer a mediação das informações contidas nos ambientes de mediação de informações, precisam, no atual contexto informacional, ser dialógicas. Primeiro, porque o leitor (também denominado de usuário) não é mais um sujeito paciente, mas é um sujeito tanto paciente, quanto agente, uma vez que no atual contexto informacional ele é editor de seu próprio texto e de vários conteúdos informacionais; é ele quem está indexando nas páginas web para outros usuários recuperarem o seu texto; todavia, essa forma de indexar, para haver uma maior precisão no processo de recuperação da informação precisa ser controlada, mas também, não pode deixar de lado a forma de busca dos usuários. Daí, a importância da ordem informacional dialógica, que busca não utilizar uma forma em detrimento da outra, mas sim a simbiose, o diálogo entre as duas formas de linguagens. Portanto, são ideias que vem ao encontro daquelas de Sousa Santos (1989), ou seja, não utilizar nem a linguagem técnica, nem só a popular, mas recriá-las, comportanto as configurações linguísticas intermédias.

Reiterando, se o bibliotecário é tomado como mediador, a biblioteca e a escola seriam mais um dos espaços de mediação, conforme nos sugere Caune (2000). Portanto, a mediação pode ser examinada como um conjunto de práticas sociais que se desenvolvem em diferentes domínios institucionais e que visam construir um espaço determinado e legitimado pelas relações que se manifestam. Assim, as instituições como a escola, as mídias ou agora as empresas culturais podem ser analisadas em função das relações interpessoais que eles autorizam. Reiterando, Veillette (2008, p. 114) afirma que "podemos, dificilmente, falar da intervenção de um mediador neutro e imparcial quando é precisamente a cultura quem interpela e faz mediação".

É nesse contexto de percepção do bibliotecário enquanto um mediador informacional e cultural que se passa a demandar novos modelos de formação dos profissionais da informação/bibliotecários, devido aos novos formatos dos processos e dos dispositivos de mediação. Esses novos modelos que são constantemente demandados tornam cada vez mais necessários investimentos em pesquisas acerca do ensino e da educação bibliotecária, portanto:

O discurso sobre o ensino de Biblioteconomia e Ciência da Informação construído no Brasil é curto e assistemático. Isso significa que, possivelmente, poucos pesquisadores ou profissionais se interessam e tratam do tema, o qual se insere na problemática mais ampla da educação bibliotecária (SOUZA, F., 2006, p. 151). 
Se poucos são os pesquisadores que se interessam pela área de educação bibliotecária, menos ainda são aqueles que possuem seus estudos voltados para a análise dos documentos elaborados para o ensino de graduação em Biblioteconomia, pois:

No Brasil, o estudo da Educação Bibliotecária ainda tem caráter mais histórico que sociológico ou educacional embora haja produção recente oriunda de pesquisas acadêmicas que reforçam as duas vertentes, tendo como fontes dissertações e teses, transformadas em livros ou não, como as de Souza (1991), Castro (2000), Lima (1999) e Hillesheim (2001) (SOUZA, F., 2002, p. 4-5).

Portanto, na análise acerca dos projetos pedagógicos dos Cursos de Biblioteconomia, Souza, F. (2006, p. 31-32) afirma:

\begin{abstract}
a profissão de bibliotecário e as práticas do cientista da informação, deveriam ser tratadas como projetos político-pedagógicos sob uma dupla abordagem: da preparação de pessoal para atuar num ambiente profissional que demanda habilidades técnico-gerenciais (a formação graduada em Biblioteconomia) e da preparação de pessoal para atuar num ambiente profissional que demanda habilidades de investigação (a formação pós-graduada em Ciência da Informação). Esses campos de conhecimento, então, darão base, respectivamente, à existência social do Bibliotecário e do Cientista da Informação, compondo o que poderia vir a ser designado pela expressão profissões da informação.
\end{abstract}

Esta proposta de Souza, F. (2006) é complementada pela de Sousa (2008, p. 8, grifo nosso), quando este indaga:

É possível chegarmos a pensar em um único curso de graduação em Ciência da [Mediação da] Informação com habilitações em Arquivologia, Biblioteconomia e Museologia? Estamos dispostos a essa discussão desde que haja um reconhecimento entre os interlocutores, pois só podemos pensar em diálogo quando os interlocutores se reconheçam como tal, e haja, também, respeito às especificidades de cada objeto de trabalho. E o fato da maioria dos cursos de Arquivologia estarem em unidades acadêmicas próximas da Ciência da Informação e da Biblioteconomia facilita esse debate e, inclusive, o motiva.

Outra questão a que este pesquisador se refere é a relação entre ensino e pesquisa na formação dos profissionais da informação/bibliotecários, e, para ele, o ensino de Biblioteconomia deveria agregar a aproximação de estudantes de graduação em Biblioteconomia com o trabalho de pós-graduandos em Ciência da Informação de algumas das escolas brasileiras. Complementando, encontramos Fujino e Vasconcelos (2011) afirmando que o estágio curricular, ou extracurricular, é um dos componentes essenciais do 
processo de formação profissional, pois podem ser vistos como espaço de estudos e de prática social no âmbito profissional.

Portanto, para Souza, F. (2001, p. 10) a avaliação das escolas de Biblioteconomia deveria sintetizar um conhecimento e integrá-lo num contexto real, daí a importância, para o autor, dos laboratórios como locus operativo e os estudos de casos, a identificação dos casos concretos para estudos resolutivos, a integração comunitária como agente de captação de recursos junto a entidades e empresas como modus metodológico. Em relação à integração dos bibliotecários e de sua formação ao contexto sócio-histórico, encontramos Cysne (1993) a qual analisa a dimensão social e educativa da Biblioteconomia. A referida autora afirma que os cursos de Biblioteconomia devem propiciar a formação de bibliotecários cuja prática tenha como objetivo maior,

a difusão do saber produzido e sistematizado, de modo a garantir à população o acesso aos conhecimentos necessários à solução dos problemas do seu dia a dia, à elevação de seu nível cultural, de modo a que possa o bibliotecário participar mais ativamente das decisões sociais, buscando-se resgatar o conceito e a prática da cidadania (CYSNE, 1993, p. 21).

O saber nesse modelo de ensino deixa de ser conteudístico e passa a ser aplicação e reelaboração. Também propondo um novo modelo de formação de bibliotecários Milanesi (2002, p. 15) afirma que:

É, portanto, possível delimitar três áreas distintas e dividir, assim, os currículos para formar profissionais da informação. A primeira é o campo da mediação que deve ser estabelecida entre a informação e os escolares ou, amplamente, as crianças e adolescentes. Essa é uma área abandonada, ainda que fundamental e de importância estratégica para o desenvolvimento da sociedade. A segunda é a informação pública, esse profissional deve ter informação ampla, variada, ter sensibilidade para sentir o meio social e capacidade de perceber os sinais que dele emergem. Se assim não for, existirá o técnico das rotinas e não aquele profissional que se espera,capaz de mudar o meio onde vive. A terceira é a informação para especialistas. Essa área exige um profissional que esteja familiarizado com o tema para que possa conhecer os meandros do campo e o seu universo semântico, bem como dialogar com os seus usuários.

É, portanto, o primeiro campo de delimitação da formação de bibliotecários, proposto por Milanesi (2002) que nos aprofundamos nesta pesquisa, a saber, o campo da mediação. Todavia, não podemos falar de processos mediacionais, tanto de culturas quanto de informações, sem também nos reportarmos às informações que são transmitidas e recebidas, significadas e ressignificadas em todo processo mediacional, ou seja, não podemos falar de 
mediação sem falarmos de fluxos, pois toda ação de mediação tem em si fluxos de informação. Mas, o que seria fluxo de informação?

O conceito de fluxo na literatura não sofre de desemprego. Numa primeira busca acerca desse conceito, encontramos vários outros termos relacionados a ele, dentre os quais: fluxo de sangue (o curso do sangue no corpo dos animais), fluxo solar (quantidade de energia emanada pelo sol), fluxo gênico (a transferência de genes de uma população a outra), dentre outros. O que é importante perceber é que o conceito de fluxo remonta à Filosofia antiga, mais precisamente ao filósofo Heráclito de Éfeso, o qual chamou a atenção para a perene mobilidade de todas as coisas que são: nada permanece imóvel e nada permanece em estado de fixidez e estabilidade, mas tudo se move, tudo muda, tudo se transforma, sem cessar e sem exceção. Para exprimir essa realidade, ele se valeu da imagem do fluir de um rio, em fragmentos que se tornaram célebres: "não se pode descer duas vezes ao mesmo rio e não pode tocar duas vezes uma substância mortal no mesmo estado, mas por causa da impetuosidade e da velocidade da mudança, dispersa-se e recolhe-se, vem e vai" (REALE, 1993, p. 64).

Na modernidade, e na contemporaneidade, esse conceito foi (re)apropriado por diversas áreas de conhecimentos, dentre elas, a Matemática, a Física, a Biologia, a Medicina, a Ciência da Informação, dentre outras. Portanto, podemos afirmar que o conceito de fluxo de informação é utilizado, principalmente, por três campos diferentes de conhecimentos: a Semiótica, que considera a influência dos fluxos na construção do discurso; a Teoria da Informação, fortemente influenciada por modelos matemáticos e de informática; e a Teoria da Comunicação, que identifica tais fluxos com a organização geopolítica e geocultural do mundo.

Apesar de o conceito de fluxo estar presente nas áreas de conhecimentos supracitadas, o objeto de interesse de nossas reflexões está no conceito de fluxo, oriundo da teoria da informação e em diálogo com os conceitos da comunicação, que está nos sistemas de informação desde a gênese dos mesmos que remonta às primeiras bibliotecas. Na contemporaneidade, os encontramos em quaisquer lugares, e de forma anárquica, independentemente de estarem ordenados no ambiente das bibliotecas, ou ordenados apenas na memória humana e prontos para serem documentados, haja vista essas memórias precisarem ser registradas fisicamente, fora da cognição humana, para permacerem no tempo.

Em nossas primeiras buscas acerca do conceito de fluxo de informação na área da Ciência da Informação, encontramos o de Barreto (1998, p. 122) para quem o fluxo seria uma sucessão de eventos, de um processo de mediação entre a geração da informação por uma 
fonte emissora e a aceitação da informação pela entidade receptora. Todavia, para o referido autor, o fluxo de informação, que, mediante processos de comunicação, realiza a intencionalidade do fenômeno da informação, não almeja somente uma passagem (como na teoria da informação), pelo contrário, ele pretende atingir o público a que ele se destina e promover uma alteração, ou seja, ele pretende que a informação seja significada pelo indivíduo. Portanto, podemos perceber que a noção de fluxo de informação vem sendo ampliada para a Ciência da Informação, uma vez que a referida área de conhecimento vem se preocupar com a informação (que é fluxo) e os seus processos mediacionais e organizacionais. Se pensarmos numa informação, conforme nos coloca Barreto (1998), como algo que sempre esteve no mundo em busca de que fosse significado pelos indivíduos, o conceito de fluxo de informação pode ser ampliado.

Os fluxos de informação são constituídos a partir dos processos de mediação da informação. Portanto, a mediação é um "ente" que já está presente desde quando nascemos, pois o bebê, ao chorar quando nasce, já está comunicando, mediando informações acerca de sua chegada e de seu estado de saúde para o mundo, portanto, é uma forma de representação para mediação e comunicação. Se o mundo é pleno de dados que, por meio da mente humana, e pelos seus processos de significação, podem se tornar informações, então, podemos afirmar que todas as coisas do mundo precisam ser pensadas para poder existir, e a informação em si não existe, haja vista já nascer mediada, e as coisas que vemos e ouvimos existem porque são representadas, mas a representação do ser não é o "ser", mas apenas aquilo que percebemos do ser. Portanto, a informação já nasce mediada e, haja vista a impossibilidade de pensarmola, pensamo-la através de nossas representações acerca do que seria a informação para nós; portanto, pensamos essa informação e comunicamo-la por meio da linguagem, que é representação. Todavia, a linguagem não nos transmite a experiência da informação, pelo qual essa informação se dá, mas evoca apenas a aparência da informação. Nesse sentido, é impossível pensar a informação, senão por meio das nossas representações, que é expressa por meio da linguagem; então, a informação já nasce mediada e, portanto, a informação não existe como ser em si, mas sim, apenas a mediação da informação (ou seja, a informação já nasce como mediação), que se apresenta para nós e a percebemos em forma de fluxos, dentro desse ambiente informacional que é o mundo e suas coisas (por exemplo, as instituições, que também são ambientes informacionais). Portanto, no mundo e nas organizações sociais, há constantes fluxos de informação, os quais são o insumo básico e vital de quaisquer organizações: 
os fluxos de informação ou fluxos informacionais se constituem em elementos fundamentais dos ambientes informacionais, de tal forma que não há ambiente informacional sem haver fluxos de informação e vice-versa. Os fluxos informacionais são reflexos naturais dos ambientes aos quais pertencem, tanto em relação ao conteúdo quanto em relação à forma (VALENTIM, 2010, p. 13).

Podemos, pois, perceber que a estrutura dos fluxos de informação são influenciados pela cultura e pela comunicação organizacional, as quais fornecem a dinâmica necessária aos fluxos de informação. São os ambientes, as organizações, que influenciam essa dinâmica, uma vez que cada ambiente organizacional possui sua própria cultura ou subcultura e forma de comunicação, ou seja, os fluxos possuem uma dinâmica não-uniforme, porquanto cada área e/ou setor possui seu próprio mecanismo de interação com o todo, de modo que há uma não-uniformidade nos fluxos de informação, dificultando seu gerenciamento (VALENTIM, 2010, p. 15). Todavia, não são apenas os ambientes que influenciam na dinâmica dos fluxos informacionais, mas também, o aperfeiçoamento das TICs, dificultando cada vez mais quantificar o volume de informações que circula na rede.

A forma e a velocidade desses fluxos vão depender das condições ambientais, as quais influem na dinâmica e na uniformidade dos fluxos informacionais. As pessoas, elementos-chave dessa dinâmica, são influenciadas por essas condições, que, por sua vez, influenciam os fluxos de informação. Além disso, os fluxos de informação são resultados das ações organizacionais, ou seja, estão imbricados tanto ao ambiente interno, quanto ao ambiente externo. Todas as alterações ambientais influenciam de alguma forma os fluxos informacionais existentes. Ressalta-se, portanto, que o ambiente estável propicia a existência de fluxos informacionais uniformes, por uma vez que atuam de forma mais integrada e, muitas vezes, até padronizada. Por outro lado, o ambiente instável propicia a existência de fluxos não uniformes, porquanto, é resultado da própria instabilidade do ambiente organizacional (VALENTIM, 2010, p. 16).

Certamente, os fluxos de informação existentes nos ambientes organizacionais são produzidos, naturalmente, pelas próprias pessoas e setores que nela atuam, a partir das atividades, tarefas e decisões que vão sendo realizadas. No decorrer do fluxo, a mesma informação pode ser usada/aplicada para outros objetivos e, neste caso, ajusta-se o jargão e agrega-se ou não outros valores que, inicialmente, a informação não possuía, ou seja, a informação é mutável e não estática como em outros ambientes informacionais. Cada um dos níveis produz informações e, portanto, fluxos de informação distintos, cuja aplicação é diversa e dependerá, essencialmente, dos conteúdos informacionais produzidos, dos objetivos do 
porquê foram produzidos, bem como dos objetivos de uso por parte de outras pessoas e setores, o que valorará a importância e pertinência da informação (VALENTIM, 2010, p. 17).

Em relação à Teoria da Informação de Claude Shannon e Warren Weaver, também encontramos o conceito de fluxo de informação. Para os referidos autores, se a informação, ao ser mediada da fonte para o receptor, não sofrer a interferência de uma fonte de ruído, o fluxo passará livremente; todavia, caso exista alguma fonte de ruído, o fluxo estanca e não há passagem de informação, podendo esta chegar deformada ao receptor, o que produz uma contra-informação ou uma não-informação. Essa teoria de Shannon e Weaver vem percorrendo a trajetória da Biblioteconomia ao longo dos anos, mas não apenas da Biblioteconomia, mas de outros campos de saberes, dentre os quais, a Educação, quando, por exemplo, em sala de aula, o professor transmissivista acredita que a informação por ele transmitida foi assimilada e significada pelos seus alunos, etc.

Quadro 4- Modelo de Comunicação de Shannon e Weaver

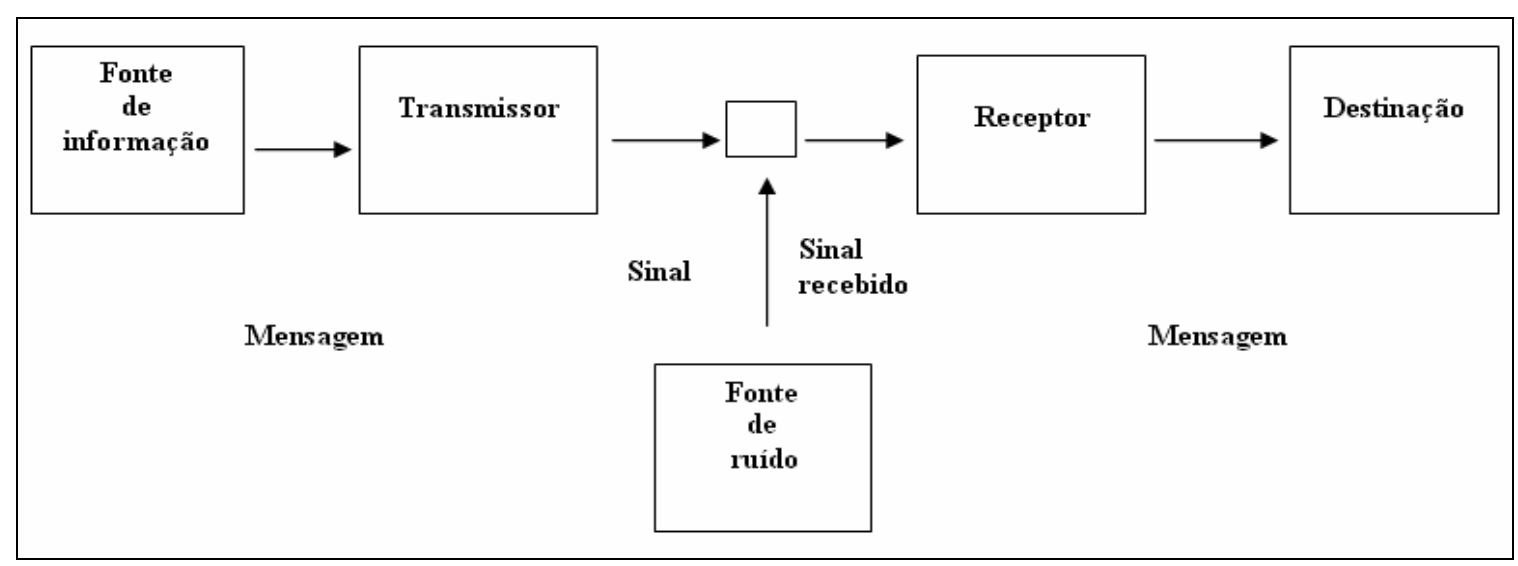

Fonte: Capurro; Hjørland (2007)

Embora possamos visualizar o fluxo de informação na teoria da informação (ou teoria matemática da comunicação), autores como Capurro (2003, p. 7) afirmam que, na teoria de Shannon e Weaver (Quadro 4), há um objeto físico que um emissor transmite a um receptor; todavia, eles não denominam esse objeto como informação, mas como mensagem e é esta quem reduz a incerteza e não a informação, pois esta quanto maior o seu volume, mais temos de selecionar a informação pertinente e maior é a insegurança do receptor. Para Capurro (2003), o que no campo da Ciência da Informação essa teoria exclui, é o papel ativo do sujeito cognoscente no processo de recuperação da informação.

Essa já era uma crítica recorrente nos estudos culturais da comunicação, que veem um grande equívoco na aplicação da teoria de Shannon e Weaver ao mundo social, na medida 
em que ela foi concebida, primariamente, como um problema de engenharia- ou seja, a transmissão de mensagens por redes de telefonia. Sua utilização na compreensão do fenômeno sociocultural de circulação e comunicação da informação acaba desembocando em análises lineares, de cunho behavorista. A própria noção de "ruído" aplicada a esses processos é indicativa dessa veiculação mecanicista, como aponta Almeida (2012, p. 116): “'ruído’ é o outro nome para o caldo simbólico e de representações sociais no qual estão imersos produtores, mediadores e usuários da informação. Na circulação das informações e na construção do conhecimento, o rumor de fundo que nunca cessa é sempre o da cultura".

Barreto (1998, p. 125) classifica os fluxos de informação em duas categorias: fluxos tradicionais e contemporâneos. Os fluxos informacionais tradicionais são aqueles do documento escrito e possui como características uma ideologia interna que está sedimentada há cerca de cinquenta anos, cujos principais pontos são: 1) unidirecionamento- o receptor da informação tem acesso a um estoque de informação a cada interação; ou, a cada tempo de interação, o receptor tem acesso a um acervo físico por vez, seja na biblioteca, no arquivo ou no museu. 2) A estrutura da informação possui a mesma característica em sua totalidade: ou é uma estrutura textual, mas de estrutura linear, ou um objeto, som ou imagem. 3) Existe sempre a mediação de um profissional de interface para o receptor interagir com o fluxo de informação, ou em sua questão inicial, ou na avaliação do produto final. 4) Encadeamento interno dos eventos é povoado por rituais de encadeamento da informação. Esses protocolos de segredo se verificam em várias fases da organização interna da informação para armazenamento e recuperação. O primeiro dá-se quando o conteúdo do documento é representado, substituindo a linguagem natural, ocultando a informação logo na sua entrada no sistema. É nesse momento que os rituais de ocultamento ocorrem, ou seja, no processamento da informação, para armazenamento e recuperação.

Já os fluxos informacionais contemporâneos são aqueles que foram alterados estruturalmente, pois atuam nos seguintes pontos: na interação do receptor com a informação, ou seja, o receptor da informação deixa a sua posição de distanciamento alienante em relação ao fluxo de informação e passa a participar de sua fluidez como se estivesse posicionado em seu interior. Sua interação com a informação é direta, conversacional e sem intermediários. A facilidade de ir e vir: a dimensão de seu espaço de comunicação é ampliada por uma conexão em rede, o receptor passeia por diferentes memórias ou estoques de informação no momento de sua vontade. Contudo, Barreto (1998) afirma que o fator de maior entrave ao desenvolvimento e ao livre fluxo de informação é a ideologia envelhecida daqueles que defendem os rituais de ocultamento da informação ao reformatarem as mensagens com seus 
instrumentais de metalinguagens, metaconhecimento e universos semânticos privados (BARRETO, 1998, p. 126).

Outra classificação de fluxos informacionais que encontramos foi a de Valentim (2010), para quem os fluxos de informação podem ser categorizados como formais (estruturados) ou informais (não-estruturados). Os fluxos informacionais estruturados se caracterizam por sua visibilidade, se constituem no resultado das atividades e tarefas desenvolvidas de forma repetitiva no ambiente organizacional, são apoiados por normas de procedimentos e especificações claras, são registrados em diferentes suportes, circulam em distintos meios, além disso, há a gestão da informação por uma ou várias pessoas, cuja responsabilidade se refere à organização, tratamento e disseminação das informações que por ele perpassam, de forma que o acesso e o uso possa de fato ser efetivo (VALENTIM, 2010, p. 18-19).

Os fluxos informacionais não-estruturados caracterizam-se, quase sempre, por sua invisibilidade, porquanto, constituem-se no resultado de vivências e experiências individuais e grupais dos sujeitos organizacionais, são apoiados pela aprendizagem organizacional e pelo compartilhamento/socialização do conhecimento entre as pessoas. Nem sempre esses fluxos que são registrados, também circulam em distintos meios (colégio invisível, sistemas de informação internos específicos para esse fim (Intranet)). Os fluxos informacionais nãoestruturados são de difícil gestão, pois requerem uma cultura organizacional que permita uma ação efetiva e, nem sempre, isso é possível, principalmente, em ambientes organizacionais mais conservadores (VALENTIM, 2010, p. 20).

Em cada ação desenvolvida por uma pessoa/setor, geralmente, se agrega valor a informação recebida, cuja dinâmica fará com que ela retorne novamente ao fluxo em questão, contudo já modificada; ou seja, é uma informação com valor agregado, que, novamente, será acessada por outra pessoa/setor, cujo uso, novamente, agregará novo valor em uma espiral sem fim (VALENTIM, 2010, p. 20-21).

Todas estas questões acerca dos fluxos informacionais das organizações podem ser utilizadas para se pensar numa formulação do conceito de fluxo de informação curricular, haja vista o currículo poder ser visualizado como uma organização, já que ele está relacionado a todos os setores da comunidade acadêmica. 


\section{TRILHAS INVESTIGATIVAS: O CONTIDO E O NÃO CONTIDO NOS CURRÍCULOS}

Ensinar não é transferir conhecimento, mas criar as possibilidades para a sua própria produção ou a sua construção (Paulo Freire).

Este capítulo aborda o objeto de estudos desta dissertação, que são os documentos produzidos pelo MEC, pela ABECIN e os PPPs e programas de disciplinas da UFPA, UFSC, UNB, USP e UFC. Portanto, o primeiro passo da nossa análise foi a leitura flutuante das Diretrizes Curriculares Nacionais para os Cursos de Biblioteconomia no País, a fim de encontrar as primeiras unidades de registro do material empírico. As unidades de registro desta pesquisa são palavras, conjunto de palavras e temas que se sobressaem dos conteúdos dos documentos em análise. Para tanto, foram utilizados como primeiros norteadores da determinação das unidades de registro os objetivos desta pesquisa. As unidades de registro utilizadas são aquelas de cunho semântico, ou seja, não analisamos as unidades de registro conforme os aspectos formais - levando em consideração o grupo gramatical a qual pertence a palavra. Como vamos analisar as unidades de registro conforme os aspectos semânticos, as unidades de registro selecionadas serão os temas presentes nos documentos propostos para análise. Em seguida, reunimos as unidades de registro temáticas em categorias, conforme critérios semânticos. As categorias foram reunidas de forma tanto apriorística (sugerida pelo referencial teórico), quanto não-apriorística (elaboradas após a análise do material).

As reflexões aqui apresentadas partem do pressuposto de que, em qualquer sistema social, os currículos, independentemente da área de conhecimento, refletem, em maior ou menor grau, o imaginário e a ideologia de seu tempo, e formam os profissionais para atuar na sociedade de acordo com essa cosmovisão.

A amostra selecionada por esta pesquisa restringe-se ao estudo do currículo de Biblioteconomia, mais especificamente dos Projetos Político-Pedagógicos, de um estado por região, para se ter uma visão geral dos currículos de Biblioteconomia no Brasil. Nossa proposta abrange o estudo dos currículos dos Cursos de Biblioteconomia da UFPA, UFSC, UNB, USP e UFC. A escolha dessas universidades buscou contemplar as cinco regiões brasileiras (Sul, Sudeste, Norte, Nordeste e Centro-Oeste), abrangendo o contexto tanto de regiões mais desenvolvidas como das mais carentes.

Outras fontes importantes para refletir e dialogar acerca da estruturação dos currículos dos cursos de Biblioteconomia no Brasil são as séries de documentos sistematizados pela ABECIN, dentre outros, o Projeto Pedagógico e Avaliação da 
Graduação: Referências para a renovação e ressignificação do Ensino em Biblioteconomia/Ciência da Informação.

Para a consecução do que propomos neste estudo, partimos de uma pesquisa teórica exploratória, que é desenvolvida com o objetivo de proporcionar ao investigador uma visão geral, de tipo aproximativo, acerca de determinado fato. É realizada quando o tema escolhido ainda é pouco explorado e, por isso, torna-se difícil formular hipóteses precisas e operacionalizantes sobre ele (GIL, 1999). Por meio da pesquisa exploratória de cunho bibliográfica realizamos um percurso que se concentrou na literatura especializada nas áreas de História, Sociologia, Educação, Filosofia (especialmente no que tange às definições, aplicação e problematização do conceito de mediação), da própria Biblioteconomia e, também, sobre as bases epistemológicas da Ciência da Informação. Desse modo, foram utilizados autores tanto das Ciências da Informação quanto das ciências que cruzam os campos supracitados.

Quanto ao Método ou Metodologia Comparativa, trata-se de uma técnica que procede da Sociologia Histórica e da Educação Comparada. O emprego da comparação em educação representa um importante instrumento analítico que possibilita resgatar a heterogeneidade, a singularidade e a complexidade dos processos educativos, incluindo a construção, manutenção ou reformulação dos currículos das diversas áreas. Este método, conforme o próprio título sugere, permite realizar comparações com finalidades de verificar semelhanças e diferenças nas identidades dos conhecimentos. E é exatamente esta questão que se coloca na base da elaboração do trabalho. Podemos dizer, ainda, que este procedimento analítico relaciona-se ao contexto das análises de conteúdos (BAUER; GASKELL, 2002). O método comparativo é inerente ao campo das ciências sociais, permitindo "descobrir regularidades, perceber deslocamentos e transformações, construir modelos e tipologias, identificando continuidades e descontinuidades, semelhanças e diferenças, e explicando as determinações mais gerais que regem os fenômenos sociais" (SCHNEIDER; SCHMITT, 1998, p. 1).

Ainda segundo estes autores, o método comparativo implica numa série de procedimentos que refletem as diversas orientações teóricas e metodológicas: 1) A seleção de uma ou mais séries de fenômenos que sejam efetivamente comparáveis (aqui deve ser considerado o número de casos e número de variáveis, quanto maior for o número de casos mais difícil será aplicar as variáveis); 2) a definição dos elementos a serem comparados; 3) a generalização. Desse modo, o que se busca é evitar que os dados obtidos não se tornem um rol de curiosidades, mas, ao contrário, que se alcancem níveis estratégicos pelos quais os fatos, 
ou acontecimentos, se iluminem reciprocamente nas suas diversidades, para dar origem a um modelo que evite a simples descrição.

Como já mencionado anteriormente, o estudo do fluxo de informações curriculares, ou seja, a interrelação estabelecida entre as disciplinas do currículo, conforme um processo pré-estabelecido, apresenta-se como uma possível ferramenta de identificação de determinadas ênfases e opções programáticas no processo de construção curricular. A análise do fluxo de informações presentes nos currículos e suas interfaces com os demais setores de cada instituição universitária poderiam permitir uma melhor compreensão do próprio processo de construção curricular, mas por questões relativas ao próprio dimensionamento dessa pesquisa, não tivemos condições de realizá-la. Eventualmente, fizemos referências a algumas disciplinas mais diretamente relacionadas à questão da mediação. Concentramo-nos na análise dos respectivos Projetos Político-Pedagógicos e das atividades de mediação da informação que são contempladas nos mesmos, vislumbrando possibilidades de melhorias nesse processo.

Também nos pautamos pela Análise de Conteúdo como método analítico que surgiu na década de 30, nos Estados Unidos. Desde quando analisavam os textos religiosos (hermenêutica), era praticada a interpretação como forma de observar um dado fenômeno. As análises dos conhecimentos produzidos pelos homens é uma construção que parte do mundo sensível (concreto, histórico e social). Para Berelson (1954 apud BARDIN, 2011, p. 24) “é uma técnica de investigação que tem por finalidade a descrição objetiva, sistemática e quantitativa [mas também qualitativa] do conteúdo manifesto da comunicação". Portanto, "pode-se aplicar a uma grande diversidade de materiais, como permite abordar uma grande diversidade de objetos de investigação: atitudes, valores, representações, mentalidades, ideologias, etc.” (LAVILLE; DIONNE, 1999, p. 214). No campo da educação,

\footnotetext{
por esta abrangência metodológica, a análise de conteúdo é também uma das técnicas mais utilizadas, ajudando o pesquisador, seja ele mestrando, doutorando, professor universitário, participante de programas de iniciação científica a identificar a significação do texto que está se analisando. $\mathrm{Na}$ área de educação, a análise de conteúdo pode ser, sem dúvida, um instrumento de grande utilidade em estudos, em que os dados coletados sejam resultados de entrevistas (diretivas ou não), questionários abertos, discursos ou documentos oficiais, textos literários, artigos de jornais, emissões de rádio e de televisão. Ela ajuda o educador a retirar do texto escrito seu conteúdo manifesto ou latente (OLIVEIRA, E., 2003, p. 5).
}

Para tanto, seguimos os passos propostos por Campos (2004): 1) Leitura flutuante, depois de estabelecido o corpus a ser analisado. 2) Seleção das unidades de análise (palavras, sentenças, frases de entrevistas, diários ou livros) a fim de realizar a análise temática. Para essa análise são utilizados os objetivos do trabalho e algumas teorias como primeiros 
norteadores. 3) Processo de categorização e de subcategorização. Essas categorias podem ser apriorísticas ou não apriorística. Apriorística: possui categorias pré-definidas e nãoapriorística: emergem totalmente do contexto das respostas dos sujeitos da pesquisa, o que, inicialmente, exige do pesquisador um intenso ir e vir ao material analisado e teorias embasadoras, além de não perder de vista o atendimento aos objetivos da pesquisa.

As unidades de registro do material empírico foram transcritas para o texto das nossas análises, integralmente, e diferenciadas das análises com a marcação do texto original com o tipo de letra itálico. As categorias de análise deste trabalho foram definidas, tanto apriorística, quanto não-aprioristicamente, ou seja, as categorias definidas a priori são as seguintes: pós-modernidade, neoliberalismo, Sociedade da Informação, avaliação, mediação e fluxo de informação, as quais foram conceituadas e discutidas no decorrer da pesquisa bibliográfica. Já as categorias definidas de forma não-apriorística são aquelas que constituímos durante as análises e que tem relação com os objetivos da pesquisa.

Como observado anteriormente, a análise dos currículos dos Cursos de Biblioteconomia, em nível nacional, deve levar em conta o contexto sociocultural, político e econômico dos governos Fernando Henrique Cardoso (1995-2002) e Lula (2003-2010), marcados pelo debate com as ideias neoliberais em relação à educação. Para esta análise pode ser útil considerar algumas das características das propostas educacionais vinculadas ao neoliberalismo enumeradas, entre outros, por Marrach (2001), quais sejam: um descompasso entre o discurso que valoriza a educação, a escola e a política que privilegia outros compromissos; discursos sobre qualidade total, modernização da escola, adequação do ensino à competitividade do mercado internacional, nova vocacionalização, incorporação das Tecnologias de Informação e de Comunicação, abertura das universidades aos financiamentos empresariais, pesquisas com finalidades práticas, utilitárias, e de produtividade. Igualmente, vale lembrar Oliveira, M. (1998) que enumera as seguintes categorias: atrelamento da educação escolar à preparação para o trabalho; tratamento da pesquisa acadêmica segundo o imperativo do mercado ou das necessidades da livre iniciativa; valorização das técnicas de organização, do raciocínio de dimensão estratégica e da capacidade de trabalho cooperativo. Não se trata de propor uma discussão político-ideológica, mas de compreender o contexto mais amplo de discussão de propostas educacionais para a universidade que se realizou no período em questão, fator importante para analisar as alterações nos currículos dos cursos de Biblioteconomia. Desse modo, a discussão de um perfil profissional adequado aos novos tempos foi uma tônica nesse período, como atestam não só as discussões promovidas pela 
ABECIN, como a produção acadêmica da área como, por exemplo, Valentim (2002); Cunha e Souza (2006) e outros.

Nesse sentido, os currículos propõem uma figura de profissional que dialoga com esse contexto - aderindo ou contestando-o em diferentes graus. Trata-se de um escopo bastante amplo e, por isso, decidimos nos concentrar especificamente na questão da mediação, por acreditarmos ser ela o elemento estratégico para indicar o que se espera desse profissional na sua relação tanto com a sociedade, quanto com a tecnologia. Como qualquer outra análise acerca de determinada faceta da sociedade é marcada pela visão de mundo de quem a analisa, este trabalho não foi diferente. Para a sua análise definimos, portanto, como categorias, aquelas presentes na noção de mediação da informação e da cultura contidas no conteúdo informacional dos currículos analisados.

Como norte teórico de análise acerca da mediação da informação e da cultura dentro do currículo de formação do bibliotecário brasileiro elegemos o educador Paulo Freire, pois sua conceituação de mediação é a que mais se aproxima da análise que empreendemos nesta pesquisa. Para Paulo Freire, se a realidade é mediadora, a codificação representa uma dimensão dada da realidade tal como a vivem os indivíduos. Os alunos, mais que receber uma informação a propósito disto ou daquilo, analisam os aspectos de sua própria existência representada na codificação. A decodificação, em todas as suas fases, revela a visão de mundo dos homens. Enquanto a representação codificada é objeto cognoscível que mediatiza os objetos conhecedores, a decodificação - compor o diálogo em seus objetos constituintes - é a operação pela qual os sujeitos conhecedores percebem as relações entre os elementos da codificação e entre os fatos que a situação real apresenta. Em todas as fases da decodificação, os homens revelam sua visão do mundo.

Os procedimentos analíticos que realizamos seguiram os seguintes passos: 1) préanálise: organizamos o material utilizado para a coleta dos dados, assim como outros materiais que puderam ajudar a entender melhor o fenômeno da mediação; 2) descrição analítica: nesta etapa o material reunido que constitui o corpus da pesquisa é mais bem aprofundado, sendo orientado em princípio pelas hipóteses e pelo referencial teórico, surgindo desta análise quadros de referências, buscando sínteses coincidentes e divergentes de ideias; 3) interpretação referencial: é a fase de análise propriamente dita. A reflexão, a intuição, com embasamento em materiais empíricos, estabelecem relações com a realidade aprofundando as conexões das ideias, chegando, se possível, à proposta básica de transformações nos limites das estruturas específicas e gerais. Para tanto, selecionamos as categorias retiradas da revisão 
de literatura realizada. Depois de estabelecermos os quadros de referência, partimos, portanto, para a análise propriamente dita, ou seja, a interpretação referencial.

Portanto, nos próximos subitens apresentamos, discutimos e analisamos o material empírico, tendo visualizado, através dos enunciados dos textos curriculares, as categorias de análises definidas de forma apriorística e de forma não-apriorística.

Iniciamos nossa análise a partir das diretrizes curriculares do MEC para o ensino de graduação na área de Biblioteconomia, pois foi o primeiro documento a ser lançado e que propôs as mudanças no âmbito das universidades. Conforme os documentos do MEC, Diretrizes Curriculares Nacionais são o conjunto de definições doutrinárias sobre princípios, fundamentos e procedimentos da Educação Básica, expressas pela Câmara de Educação Básica do Conselho Nacional de Educação, que orientarão as escolas brasileiras dos sistemas de ensino na organização, articulação, desenvolvimento e avaliação de suas propostas pedagógicas (BRASIL, 1996). Então, trata-se de orientações que o governo propõe para as mudanças nos sistemas de ensino, em todos os seus níveis, desde o fundamental, passando pelo médio até o superior. Portanto, iniciamos analisando as diretrizes curriculares do MEC, para, em seguida, analisar os documentos da ABECIN, até chegar aos currículos.

\subsection{Caminho analítico do documento do MEC}

As Diretrizes Curriculares Nacionais que estão vigendo desde o ano de 2001, e que são objeto deste estudo, foram relatadas pelas professoras Eunice Ribeiro Durham (Socióloga e professora titular da USP), Silke Weber (Pedagoga e professora adjunto IV da UFPB) e Vilma de Mendonça Figueiredo (Socióloga e professora emérita da UNB), e remetidas pela SESu/MEC para apreciação da CES/CNE, sendo aprovadas em 3 de abril de 2001, sob o parecer CNE/CES 492/2001. Em 4 de julho de 2001, nos termos do art. $2^{\circ}$ da Lei n 9.131, de 24 de novembro de 1995, o Ministro de Estado da Educação homologou o Parecer no 492/2001, da Câmara de Educação Superior do Conselho Nacional de Educação, favorável à aprovação das propostas de Diretrizes Curriculares Nacionais dos cursos de Filosofia, História, Geografia, Serviço Social, Comunicação Social, Ciências Sociais, Letras, Biblioteconomia, Arquivologia e Museologia, conforme consta do Processo $\mathrm{n}^{\circ}$ 23001.000126/2001-69.

A busca de uma harmonização curricular foi iniciada pela Associação Brasileira de Ensino em Biblioteconomia e Documentação (ABEBD), em 1996, quando reuniu, em Porto Alegre, os cursos superiores da Argentina, do Chile, do Uruguai, do Paraguai e do 
Brasil. Naquele momento, foi estabelecida a metodologia a ser desenvolvida e determinadas as metas a serem alcançadas em que, durante um evento realizado em São Luís, em julho de 1997, foram obtidos os primeiros resultados. Em novembro do mesmo ano, chegou-se ao estabelecimento do núcleo principal de conhecimentos, os quais foram integrados em seis áreas: 1) Fundamentos Teóricos da Biblioteconomia e da Ciência da Informação; 2) Processamento da Informação; 3) Recursos e Serviços de Informação; 4) Gestão de Unidades de Informação; 5) Tecnologia da Informação; 6) Pesquisa.

Após a realização do II Encontro de Dirigentes dos Cursos Superiores de Biblioteconomia dos Países do MERCOSUL, realizado em novembro de 1997, em Buenos Aires, a ABEBD, atual Associação Brasileira de Educação em Ciência da Informação (ABECIN), dando cumprimento à recomendação do referido evento, encaminhou ao Ministério da Educação (MEC) os resultados do processo de harmonização curricular alcançados.

Em 10 de dezembro de 1997, a Secretaria de Educação Superior (SESu) do MEC, lançou o Edital n. 4/97 convocando todos os cursos a apresentarem, até maio de 1998, propostas para as novas Diretrizes Curriculares Nacionais dos cursos superiores, que seriam elaboradas pelas Comissões de Especialistas da Sesu/MEC. Com relação aos Cursos de Biblioteconomia, a grande maioria dos mesmos decidiu encaminhar as propostas aprovadas em Buenos Aires. Foram realizados alguns encontros específicos para debater a questão (em Curitiba (PR) e em João Pessoa (PB), por exemplo) e, em outros casos, como na UNESP, Uni-Rio, UFMG, UFG houve uma aceitação direta das propostas. A partir deste fato e da aceitação formal do MEC com relação às propostas de Buenos Aires, as tendências são de que os novos currículos plenos pautem sua organização pelas mesmas. As Diretrizes Curriculares Nacionais (QUADRO 1) para a Biblioteconomia foram lançadas no ano de 2001.

Por outro lado, quando fomos buscar essas informações acima descritas com os relatores das DCN's para a Biblioteconomia, os mesmos afirmaram que não teriam sido eles quem elaboraram as diretrizes em si. Depois contactamos o $\mathrm{CFB}$, o qual também não sabia e que pediu que contactássemos o Conselho Nacional de Educação e a ABECIN, a qual, por sua vez, também não sabia quem havia elaborado. Fato curioso uma vez que se trata da historicidade da formação dos bibliotecários brasileiros. Esses dados foram obtidos por meio de uma busca aleatória na Internet, momento em que encontramos um artigo de Jussara Pereira dos Santos (1998) que se intitula "Reflexões sobre currículo e legislação na área da Biblioteconomia", o qual foi editado pela Revista de Santa Catarina, intitulada "Encontros Bibli”. 
Após as análises realizadas podemos perceber que a formação do bibliotecário, proposta pelo MEC, busca propiciar o desenvolvimento de determinadas competências e habilidades e o domínio dos conteúdos da Biblioteconomia. Portanto, encontramos neste texto conceitos que remetem à Pedagogia das Competências. Esta concebe a educação de forma puramente pragmática e incentiva o educando a levar em consideração as mudanças técnicas e de organização do trabalho às quais ele deve se ajustar. Este fato vai ao encontro das propostas do neoliberalismo e da pós-modernidade para a educação, haja vista as duas cosmovisões valorizarem o raciocínio estratégico, objetivando resolver de forma imediata um determinado problema. Sendo assim, a palavra imediaticidade está presente desde as falas mais singelas do cotidiano aos discursos mais sofisticados dos especialistas e, é nesse contexto, que García Canclini (2007) afirma que, na sociedade contemporânea, tudo tem que ser resolvido no tempo-espaço de um clique, até mesmo os assuntos relacionados à educação.

É numa ambiência de predominância da Pedagogia das Competências que se passa, cada vez mais, a valorizar as técnicas de organização para as formações profissionais, e, portanto, o MEC corrobora com esta prática, a qual Marrach (2001) afirmara ser uma das características do neoliberalismo na educação. Todavia, este objetivo é ambivalente, pois embora possa significar a pendência para uma sociedade pós-moderna/neoliberal, conforme nossa interpretação acerca das ideias da autora em lide, este termo também pode vir a significar que, dentre as habilidades do bibliotecário, a valorização das técnicas de organização pode se constituir em uma forma de melhorar a mediação e o acesso da população ao universo documentário/informacional existente.

Outra questão que se coloca em relação aos termos competências e habilidades refere-se a que o indivíduo é o único responsável pelo seu sucesso ou fracasso. Se ele possui determinadas competências, ou não, ele será, ou não, bem sucedido no mercado de trabalho. Nesse sentido, esses dois termos em relação à educação tomam uma denotação oculta, pois representam a ideia de que se o indivíduo é bem sucedido no mercado de trabalho é porque ele investiu o suficiente em sua formação de saber fazeres (de competências), a ponto de o mercado de trabalho tê-lo absorvido; caso contrário, também é culpa do indivíduo o seu desemprego, pois é sinal de que ele não investiu o suficiente em sua formação, nem em suas atualizações. Portanto, o que mais interessa à Pedagogia das Competências é que seja inserido no ambiente educacional aquilo que Althusser (2008) denominou de savoir-faire, ou seja, as regras de consciência profissional e moral. Todavia, não é apenas nesta unidade de registro que se encontra a pendência à pedagogia em questão, haja vista que a próxima diretriz afirma que os bibliotecários além de preparados para enfrentar com proficiência e criatividade os 
problemas de sua prática profissional, devem produzir e difundir conhecimentos e buscar aprimoramento contínuo. Portanto, podemos perceber que, para a Pedagogia das Competências, o educando deve estar em constante processo de aprendizagem, como forma de atualizar-se, a fim de estar em consonância com os conhecimentos constantemente produzidos e sistematizados pela sociedade. Por outro lado, a diretriz avança no sentido de que os educandos e os próprios profissionais saem de uma postura mais passiva frente aos conhecimentos para se tornarem agentes interativos no processo de criação e construção de conhecimentos. Além disso, também está presente a ideia de um bibliotecário não mais apenas ordenador do universo informacional, mas também de facilitador do acesso, ou seja, mediador entre a informação e o usuário, quando propõe que o bibliotecário deve difundir informações ${ }^{23}$. Em relação à proposta de que o bibliotecário deve produzir conhecimentos, deve-se considerar a polissemia que a noção de produção do conhecimento pode ocasionar (haja vista que o termo produção também está relacionado à produção de mercadorias e à noção de produtividade).

Falando nas ideias de Paulo Freire e nas suas propostas para a educação, quando o documento do MEC propõe como práxis a ser desenvolvida no processo educacional dos alunos dos cursos de Biblioteconomia buscar refletir criticamente sobre a realidade que o envolve e aprender a observar padrões éticos de conduta, parecem-nos ideias que vão ao encontro da Pedagogia da Autonomia proposta por esse autor. Conforme esta pedagogia, a proposta de uma educação libertadora busca propiciar mecanismos com os quais os educandos "emirjam" na realidade, de modo a conhecê-la para, posteriormente, inserir-se nessa realidade de forma crítica e consciente. Para Paulo Freire, a realidade e os conhecimentos atuam como mediadora entre os homens e o mundo, portanto, se a realidade atua como fator de mediação, então a cultura também é e faz mediação, para utilizar os termos de Veillette (2008). É nesse sentido que compreendemos a mediação não como uma prática neutra, haja vista ela implicar seres sociais em determinado espaço social, que também não é neutro.

É nesse contexto social que os bibliotecários vão pautar a sua prática e não mais como um guardiães dos documentos, mas sim como profissionais capazes de atuar junto a instituições e serviços que demandem intervenções de natureza e alcance variados:

\footnotetext{
${ }^{23}$ Neste contexto tem-se também que ter cuidado com o conceito difundir informações, pois pode transparecer a ideia de um profissional que apenas irradia, espalha informações, sem se preocupar com a recepção e a apropriação por parte do leitor. Portanto, preferimos o conceito mediação da informação, principalmente aquele cunhado por Almeida Júnior (2009), pois fala de interferência do profissional da informação, tendo em vistas a apropriação de informações por parte do usuário da informação.
} 
bibliotecas, centros de documentação ou informação, centros culturais, serviços ou redes de informação, órgãos de gestão do patrimônio cultural etc. Portanto, o bibliotecário, além de saber dominar os processos de organização da informação, também atua no sentido de disponibilizar e mediar essa informação em quaisquer suportes físicos, ou apenas em forma de fluxos na rede. Se o bibliotecário deve atuar junto a várias instituições que demandam intervenções de natureza variada, o seu espaço de atuação não se encontra mais apenas na biblioteca, mas em vários outros espaços que tenham alguma informação a ser organizada, mediada, ou até mesmo criada. Todavia, o que nos preocupa é a elaboração do currículo de formação do bibliotecário, pois, ao ter constantemente o seu espaço de atuação ampliado, principalmente, com a constante criação de novas TICs, parece que, a cada dia, se busca inserir no currículo conhecimentos que estão emergindo na forma de retirar as disciplinas mais "tradicionais" para inserir os conteúdos mais novos. Este fato aguçou-se ainda mais com as constantes inovações tecnológicas as quais, continuamente, assediam a área da Biblioteconomia e da Ciência da Informação em busca de novas formas de organização das informações, que, no momento contemporâneo, se apresentam em forma de fluxos, em um não-lugar, além de redefinir e ampliar o campo de atuação do bibliotecário.

Embora esses constantes redelineamentos do campo profissional do bibliotecário sejam favoráveis à profissão, no campo curricular podem gerar alguns paradoxos, pois, visando a dar conta das mais variadas inovações e/ou invenções tecnológicas, os pesquisadores da área da Ciência da Informação estão cada vez mais propondo novas disciplinas para fazerem parte do currículo dos cursos de Biblioteconomia, visando, principalmente, atender aos anseios do mercado de trabalho, talvez sem atentar efetivamente para os fundamentos epistemológicos das mesmas.

Em relação às competências e habilidades gerais que o MEC propõe para a formação do bibliotecário brasileiro, a primeira trata-se de gerar produtos a partir dos conhecimentos adquiridos e divulgá-los. Em primeiro lugar, esta diretriz pode apontar para uma pendência ao neoliberalismo o qual, conforme analisou Marrach (2002), visa à transformação de tudo em mercadoria, fazendo com que os conhecimentos deixem de se tornar cada vez mais instrumentos que, se apropriados pelos indivíduos, possam vir a possibilitar a emancipação dos mesmos, para se tornar cada vez mais instrumentos de corroboração do status quo vigente. Por outro lado, em sua ambivalência, para utilizar os termos de Bauman (2005), a diretriz também pode vir a contemplar os produtos informacionais gerados a partir dos conhecimentos adquiridos. Na realidade, o que incomoda em relação a algumas terminologias que são utilizadas nos documentos educacionais é que se 
apropriam de termos oriundos do mundo do mercado e os inserem, muitas vezes, sem pensar, no mundo educacional.

Sendo o bibliotecário também um mediador de informações e das mais variadas culturas em sua práxis, então, ele deve estar apto a formular e executar políticas institucionais e elaborar, coordenar, executar e avaliar planos, programas e projetos. Estas diretrizes vão ao encontro da formação de um bibliotecário mediador, pois vislumbram a possibilidade de esse profissional atuar na formulação de políticas culturais, principalmente, no sentido de engajar a coletividade tendo em vistas favorecer a apropriação dos projetos e das práticas culturais por parte dos usuários. Daí a importância de o profissional não apenas atuar em locais fixos, mas buscar se beneficiar dos mecanismos de uma sociedade que opera em rede e, nesse sentido, desenvolver atividades profissionais autônomas, de modo a orientar, dirigir, assessorar, prestar consultoria, realizar perícias e emitir laudos técnicos e pareceres. Portanto, nesta diretriz também está presente a categoria da mediação da informação e da cultura, pois, ao orientar, dirigir, assessorar, prestar consultoria, realizar perícias e emitir laudos técnicos e pareceres, a mediação está sendo contemplada no fazer do bibliotecário, na forma de uma mediação técnico-profissional, haja vista que a mediação também é trabalho, práticas profissionais e técnicas na visão de Rasse (2000). Esta diretriz está complementada com aquela que afirma que a formação do bibliotecário deve propiciar conhecimentos que o auxiliem a interagir e agregar valor nos processos de geração, transferência e uso da informação, em todo e qualquer ambiente, bem como criticar, investigar, propor, planejar, executar e avaliar recursos e produtos de informação. Portanto, se a mediação, conforme o autor em lide, também é técnica, então, quando a diretriz do MEC propõe uma formação de bibliotecários aptos a desenvolver e utilizar novas tecnologias, está propondo a formação de um bibliotecário-mediador; não apenas no sentido de ele saber utilizar as tecnologias, mas no sentido de ensinar ${ }^{24}$ os conhecimentos que favoreçam a apropriação, por parte dos sujeitos, das tecnologias e das informações que são constantemente produzidas; além do mais, esta unidade de registro direciona esse profissional a ser um sujeito agente nos processos de inovações tecnológicas em seu campo de atuação.

Em relação a interagir e agregar valor nos processos de geração, transferência e uso da informação, podemos visualizar a categoria da mediação no sentido da dupla mediação, a saber, social e técnica. Mediação social no sentido atribuído ao termo por Akrich

\footnotetext{
${ }^{24}$ É nesse sentido que Pieruccini (2007) afirma ser necessário ensinar a informação, haja vista a apropriação de informações não ocorrer de forma natural. Nesta via, a autora percebe a necessidade de o bibliotecário atuar como um mediador, ou, se quisermos utilizar as palavras da autora, como um infoeducador e ensinar aos educandos a utilizar a informação, tendo em vistas a sua apropriação e atuação no mundo.
} 
(1993), ou seja, de que as informações podem ser geradas, transferidas (mediadas) e usadas em diferentes instituições e de diferentes formas. A técnica também é mediadora e dependendo do tipo de técnica, ela pode mediar diferentes tipos de valores. Todavia, embora possamos perceber a categoria da mediação presente nessa unidade de registro, a expressão transferência de informação possui um conceito muito mais abrangente que o conceito de transferência. Quando se transfere algo (o que pode ser uma informação) a alguém, já está implícita uma série de mediações entre aquele que transmite e o receptor da informação que terá de buscar a significação dos dados em um conjunto de conhecimentos que ele tem $a$ priori. Daí, afirmarmos que a informação já nasce como mediação, conforme Floris (1995).

Percebendo o bibliotecário como um mediador, portanto, como um infoeducador, para utilizar expressões de Pieruccini (2007), este profissional deve saber traduzir as necessidades de indivíduos, grupos e comunidades nas respectivas áreas de atuação e, também, saber responder a demandas sociais de informação produzidas pelas transformações tecnológicas que caracterizam o mundo contemporâneo, conforme direciona o MEC. Visualizamos estes direcionamentos formativos como favoráveis à formação de um bibliotecário mediador e o conjunto das diretrizes nos leva a perceber que a visão de mediação presente nesse documento tanto está relacionada com a visão mais tradicional, ou seja, a mediação por meio da interação face a face, quanto nas suas formas mais contemporâneas, a saber, a mediação em sua forma midiatizada em lugares e não-lugares. Portanto, esta diretriz contempla aquilo que Josiane Jouët (1993) denomina de dupla mediação, a saber, a mediação que possui seu lado técnico, mas também, social.

Embora percebamos uma maior influência dos conteúdos relativos à mediação presentes nas Diretrizes Curriculares Nacionais, o MEC teve o cuidado de não deixar o documento muito técnico, quando afirma que: recomenda-se que os projetos acadêmicos acentuem a adoção de uma perspectiva humanística na formulação dos conteúdos, conferindo-lhes um sentido social e cultural que ultrapasse os aspectos utilitários mais imediatos sugeridos por determinados itens. Aqui podemos perceber que as diretrizes deixam para as escolas o direito de escolher se os seus PPPs serão mais técnicos ou humanistas e como serão transmitidos os conteúdos técnicos. Portanto, mesmo com o MEC propondo as diretrizes de formação das áreas de conhecimentos, podemos perceber que cada curso/escola pode adequar o seu PPP e o seu currículo à sua forma de ver a educação, pautando-se nas mais diversas teorias curriculares, nas mais diversas visões de mundo e, para isso, pode escolher se vai, e como vai dialogar com outros cursos. Portanto, mesmo traçando direcionamentos, o MEC possibilita ao aluno trilhar seu percurso acadêmico e podemos 
visualizar tal fato, nas diretrizes que corroboram a possibilidade de os cursos poderem ministrar matérias comuns e complementar conhecimentos auferidos em outras áreas.

Portanto, para analisar como essas DCNs do MEC, para a formação do bibliotecário, desaguaram na formação do bibliotecário brasileiro, procedemos à análise das indicativas da Associação Brasileira de Educação em Ciência da Informação (ABECIN), as quais norteiam a formação do bibliotecário em nível nacional, para podermos, em seguida, analisar os currículos (PPPs) propriamente ditos.

\subsection{Caminho analítico dos documentos da ABECIN}

A Associação Brasileira de Educação em Ciência da Informação, designada pela sigla ABECIN, foi fundada em 02 de junho de 2001, e trata-se de uma sociedade civil, sem fins lucrativos, que congrega entidades e profissionais vinculados à Educação Superior, em nível de Graduação, nas áreas das Ciências da Informação. A ABECIN foi constituída com a finalidade de assegurar o debate sobre a formação de profissionais das áreas das Ciências da Informação e congrega instituições e profissionais voltados à formação de recursos humanos em nível universitário. Tem por missão guardar relação direta com o conjunto de interesses e visões de mundo e com o ideário de permanência desse corpo profissional na sociedade. Tem por finalidade fortalecer e integrar a atuação das instituições públicas e privadas e dos profissionais de educação superior, que tenham como missão precípua a formação, no nível de graduação, de profissionais capacitados a atuar em Ciência da Informação. A referida associação tem foro jurídico na cidade de São Paulo e sede administrativa em Brasília. Podemos perceber que, pela data de criação da ABECIN, ela também foi criada tendo em vistas debater as novas diretrizes lançadas pelo MEC, um pouco antes de sua criação, ou seja, em 3 de abril de 2001.

$\mathrm{Na}$ página da ABECIN na Internet, estão disponíveis para download sete documentos que versam sobre a formação do bibliotecário, em nível brasileiro, e em nível de Mercosul, quais sejam:

Quadro 5- Lista dos documentos elaborados pela ABECIN

\begin{tabular}{|l|l|}
\hline ABECIN 1 & $\begin{array}{l}\text { Projeto Pedagógico e Avaliação da Graduação: referências para a renovação e } \\
\text { ressignificação do ensino em Biblioteconomia/Ciência da Informação (2001). }\end{array}$ \\
\hline ABECIN 2 & $\begin{array}{l}\text { Avaliação da Graduação em Biblioteconomia e Ciência da Informação: bases } \\
\text { conceituais, metodológicas e princípios do processo avaliativo (2002). }\end{array}$ \\
\hline
\end{tabular}




\begin{tabular}{|l|l|}
\hline ABECIN 3 & $\begin{array}{l}\text { Diretrizes para a Construção de Indicadores de Qualidade para a Avaliação de } \\
\text { Cursos de Graduação de Biblioteconomia e Ciência da Informação(2002). }\end{array}$ \\
\hline ABECIN 4 & $\begin{array}{l}\text { Avaliação do Processo Formativo na Área de Biblioteconomia/Ciência da } \\
\text { Informação: documento referencial (2002). }\end{array}$ \\
\hline ABECIN 5 & I Seminário Pedagógico ABECIN "Gestão da Informação (2003). \\
\hline ABECIN 6 & $\begin{array}{l}\text { Auto-avaliação do Ensino no Brasil desde a perspectiva da Pesquisa, Extensão } \\
\text { e Gestão: contribuição para um modelo de avaliação às escolas de } \\
\text { Biblioteconomia e Ciência da Informação do Mercosul (2004). }\end{array}$ \\
\hline ABECIN 7 & $\begin{array}{l}\text { Oficina pedagógica- Região Sudeste: (re)construção das práticas pedagógicas } \\
\text { no processo de ensino-aprendizagem em Ciência da Informação (2005). }\end{array}$ \\
\hline
\end{tabular}

Fonte: Pesquisa in loco.

O primeiro documento a ser elaborado pela $\mathrm{ABECIN}$, tendo em vistas a que as Escolas de Biblioteconomia tivessem um norte para elaborar seus projetos políticospedagógicos, denomina-se Projeto Pedagógico e Avaliação da Graduação: referências para a renovação e ressignificação do ensino em Biblioteconomia/Ciência da Informação e foi produzido em 2001, no evento denominado Oficina de Trabalho de São Paulo. Portanto, os documentos elaborados pela $\mathrm{ABECIN}$, pela forma como foram elaborados, refletem a visão que aquele grupo de professores possuía acerca da área da Ciência da Informação ${ }^{25}$, bem como sua visão de mundo naquele momento, também estão refletidas nesses documentos.

Portanto, analisando o primeiro documento lançado pela ABECIN percebemos que o grupo de professores da Biblioteconomia concorda que: em um mundo em rápida mutação, como o que vivemos, a educação deve ser compreendida como uma prática social que pode dinamizar outros processos sociais importantes, permitindo a busca pela construção de uma sociedade mais inclusiva. Neste sentido, a indicativa da ABECIN sintoniza-se com um dos pressupostos da pós-modernidade, por meio da categoria da mutação, ou seja, a dinamização dos processos sociais, as mudanças, como uma das características a que a educação tenha que se adaptar. Por outro lado, também percebemos nesta unidade de registro a categoria da mediação, haja vista que a prática social é uma mediação da sociabilidade, conforme a conceituação de mediação social elaborada por Floris (1995). É nesse sentido que a ABECIN afirma que a educação superior deve, portanto, estabelecer princípios que guiem não só a formação técnico-científica, que o mundo do

\footnotetext{
${ }^{25}$ É importante frisar que a ABECIN não traça diretrizes, ou seja, os cursos não têm a obrigatoriedade de seguir as indicativas da ABECIN como têm de seguir as diretrizes do MEC. Em relação à presença dos professores na elaboração das indicativas, na sua maioria, são constituídos de professores dos Cursos de Biblioteconomia, haja vista que, na época da discussão e elaboração das diretrizes, década de 1990 e inicio dos anos 2000, eram poucos os cursos de Arquivologia e Museologia existentes.
} 
trabalho requer, mas também, a formação do cidadão que uma sociedade inclusiva exige. Nesta unidade de registro estão implícitas as teorizações educativas de Paulo Freire no sentido de que a mesma alie a teoria e a prática dos conteúdos que são dialogados em sala de aula, em busca da práxis educacional e não apenas um ou outro dos polos educacionais; ou seja, não apenas se pautar na formação técnica, muito menos se pautar na formação apenas teórica, mas na simbiose entre os dois modelos formativos. Também se alia às formulações do educador quando trata da questão da formação do cidadão que uma sociedade inclusiva exige, pois o Paulo Freire dos últimos escritos estava muito mais preocupado com a defesa da cidadania e pela sua prática pelos brasileiros do pós-ditadura militar.

A noção de que a educação não deve oportunizar apenas a formação técnicocientífica também está presente quando se afirma que a formação do bibliotecário deve oportunizar condições ao estudante-cidadão de desenvolver suas atividades acadêmicas $e$ profissionais, pautando-se não só na competência e habilidade, mas também, nos princípios da democracia e da cooperação. Nesse sentido, as propostas educacionais da ABECIN para a formação de bibliotecários não vão ao encontro daquelas propostas pelo MEC, no sentido de que não se pautam apenas em competências e habilidades, em saberes-fazer, para utilizar expressões de Louis Althusser. O que percebemos é que as propostas da associação vão muito além, pois se preocupam com valores mais humanísticos, tais como a democracia e a cooperação, o que, aliás, é coerente com as propostas freirianas, haja vista este autor, principalmente, em seu livro Educação e Realidade Brasileira, ter proposto para a educação brasileira dirigir-se, cada vez mais, no sentido da democracia, superando, portanto, a centralização na palavra, nos discursos. A proposta vai ao encontro da dialogia entre a educação e o trabalho; mas não em um tipo de aliamento educação/trabalho pautado nos modelos da sociedade neoliberal, que reduz educação a mero treinamento técnico, conforme elencou Marrach (2001) como uma das características da educação neoliberal.

As indicativas da ABECIN sugerem que as escolas de Biblioteconomia busquem aliar os conteúdos do ensino às questões sociais, o que implica em analisarmos as relações existentes entre o fazer pedagógico e as questões sociais mais amplas, bem como as relações de mútua interdependência. A saber, este documento sinaliza que a formação do bibliotecário deve estar contextualizada, não apenas em forma de aderência à realidade tal qual ela está posta, mas também, como forma de vislumbrar novos horizontes, tanto para o mundo do trabalho do bibliotecário, quanto em relação ao acesso à informação por parte dos cidadãos. Há, portanto, nesta diretriz, uma preocupação em relação ao contexto em que o curso está inserido e isso se desdobra nos itens que a ABECIN propõe que sejam levados em conta na 
elaboração dos PPPs, quais sejam: compreensão da sociedade atual; identificação da população-alvo da instituição/curso; levantamento dos dados demográficos da região em que se situa a instituição/curso; identificação das atividades econômicas do estado onde se situa a instituição/curso (nível de desenvolvimento do estado); conhecimento das políticas públicas em educação e informação; levantamento do nível socioeconômico, cultural, educacional da população-alvo da instituição/curso; identificação da infraestrutura do Estado onde se situa a instituição/curso na área de informação (bibliotecas públicas, escolares e universitárias; centros de informação, etc.); número de escolas/cursos de nível superior em Biblioteconomia/Ciência da Informação; identificação do nível de utilização e acesso da população às tecnologias de informação. Estas diretrizes, pela natureza do que propõem, podem ser analisadas em conjunto.

Ao visualizarmos que a ABECIN estava propondo às escolas de Biblioteconomia que se pautassem nos princípios de Morin em relação aos seus quatro pilares para a educação do futuro, imaginávamos que ela também estivesse em consonância com este filósofo em relação ao tipo de disciplinaridade delineada por ele em relação à formação em Biblioteconomia. No entanto, ao analisarmos o documento, encontramos alguns direcionamentos para a formação do bibliotecário. O primeiro, adequação da formação a contextos específicos de atuação: tal aspecto deve expressar-se por meio da flexibilidade de conteúdos, valorizando a dimensão da interdisciplinaridade; direcionamentos estes que não vão ao encontro da proposta de Freitas; Morin e Nicolescu (1994) quando estes propõem a Carta da Transdisciplinaridade. A interdisciplinaridade refere-se a uma disciplina que vai buscar a cooperação de outras disciplinas para si, o que é bem diferente daquilo que a transdisciplinaridade propõe, ou seja, que todas as disciplinas irradiem seus conhecimentos e também sejam irradiadas por todas as outras disciplinas. Portanto, a transdisciplinaridade não busca um domínio de uma disciplina sobre as outras, mas a abertura de todas elas àquilo que as atravessa e ultrapassa. O que nos parece interessante para a formação do bibliotecário é atentar para a perspectiva transdisciplinar, ou seja, aquela perspectiva que busca transcender o universo fechado e fragmentado das ciências e busca a cooperação de todas as disciplinas entre si, onde não há uma única matéria a buscar apoio em várias outras, mas sim, que todas as disciplinas cooperem entre si e, nessa cooperação, não se saiba quem começou buscar e/ou emitir o conhecimento para a cooperação com a outra disciplina.

A perspectiva da transdisciplinaridade também está em consonância com a da mediação, haja vista que esta, na perspectiva dada por Caune (2000) busca engajar a coletividade tentando criar laços duradouros, e não efêmeros. Mas o que a ideia de mediação 
de Caune (2000) tem a ver com a ideia da transdisciplinaridade de Freitas; Morin e Nicolescu (1994)? Muito. Em primeiro lugar, porque a transdisciplinaridade busca restabelecer os laços entre a nacionalidade e a transnacionalidade, ou seja, entre a nação e a Terra, interligando, portanto, todos os seres com a Terra; já a perspectiva da mediação de Caune (2000) também se refere ao restabelecimento dos laços duradouros, efetivos entre os homens, em contraponto aos laços efêmeros de uma sociedade pós-moderna. Neste sentido, as indicativas da ABECIN, em seu conteúdo, embora afirme que valoriza a dimensão interdisciplinar, por outro lado está também aberta à perspectiva transdisciplinar quando afirma que a formação de bibliotecários deve buscar capacitar o egresso, numa perspectiva de formação integral, para atuar com competência, de modo a responder às demandas sociais; mais especificamente como gestor e mediador da informação, por meio das disciplinas associadas às quatro áreas curriculares, considerando o nível específico de formação. Portanto, ao visar à formação integral, restabelecendo os laços, nesta indicativa, a ABECIN leva em consideração as questões concernentes à mediação da informação, o que está tanto em seu texto explícito, como no implícito. Além disso, expressa em seu conteúdo que percebe o bibliotecário tanto como organizador, quanto como mediador da informação.

A questão da mediação também está presente quando as indicativas da ABECIN inserem que a avaliação é ponto de partida e ponto de chegada do processo de planejamento (concepção e operacionalização) do projeto pedagógico, implicando em que as decisões das várias etapas do planejamento se apoiem em avaliação. Conforme podemos observar está presente no conteúdo do documento da associação um dos pressupostos das teorizações tradicionais do campo curricular, a saber, a ênfase nos processos avaliativos no projeto pedagógico, fato este que deságua nas salas de aula. No entanto, a ênfase nos processos avaliativos no currículo era realizada porque se visualizava a escola como uma "fábrica de aço", no caso de Bobbitt (1918), em que os atores do processo educacional seriam os operários dessa fábrica. No entanto, se volvermos nosso olhar na perspectiva de encontro do passado, podemos perceber que até o século XX nenhuma instituição educativa apresentava uma prática similar àquela que hoje denominamos de avaliação. Esta, portanto, só passa a ser vista no meio educativo a partir do século $\mathrm{XX}$, quando se iniciam as teorizações curriculares propriamente ditas e passam a enfatizar a avaliação, numa tentativa de racionalizar os processos de ensino/aprendizagem. Portanto, a educação passa, nessa perspectiva, a ser treinadora dos indivíduos para o mercado de trabalho. Por outro lado, a avaliação também pode visar à busca do aprofundamento do conhecimento e à leitura crítica do mundo; uma avaliação que busque uma permanente apreensão da realidade, visando uma educação que 
seja, antes de tudo, crítica. Uma avaliação que não seja apenas a transmissão conteudística, mas também, que possibilite um alçar-se do aluno à atuação no mundo, que são propostas de Freire (1981) para a educação, as quais vão ao encontro daquilo que Lamizet e Silem (1967) afirmam ser mediação, a saber, formas de comunicação que asseguram a apropriação ${ }^{26}$ de informações.

Se as propostas da ABECIN em relação à avaliação estão em consonância com a perspectiva da mediação analisada por Lamizet e Silem (1967), este fato é corroborado quando a mesma afirma que essa perspectiva, do ponto de vista pedagógico, aponta para uma ruptura com as práticas tradicionais de ensinar e aprender (currículos estruturados sob a lógica teoria-prática), dando lugar privilegiado à prática do aluno, onde o estímulo à curiosidade, à busca de solução de problemas, ao despertar de interesses, à criatividade na solução de problemas, deverão ser perseguidos. Portanto, são propostas educacionais para os cursos de Biblioteconomia que pressupõem, principalmente, um aluno que seja um sujeito interagente no processo de ensino-aprendizagem e não aquele aluno que recebe passivamente os conteúdos da educação. Nesse sentido, a educação proposta é mediação no sentido dado à palavra por Lamizet e Silem (1967), ou seja, uma prática educativa que não apenas transfere, mas que media os conteúdos da educação, que busca sua a significação e apropriação por parte dos sujeitos do processo educacional.

Podemos perceber, portanto, a ênfase da ABECIN nos processos avaliativos, haja vista a mesma ter elaborado um segundo documento exclusivamente delineando os princípios avaliativos, denominado de Avaliação da graduação em Biblioteconomia e Ciência da Informação: bases conceituais, metodológicas e princípios do processo avaliativo, cujo conteúdo foi elaborado a partir da Oficina Regional de Trabalho Sudeste/Centro-Oeste em 2002. Se a avaliação buscar a apropriação das informações, buscando restabelecer os laços sociabilidade dos sujeitos, então ela é mediação. Portanto, inferimos que a avaliação proposta pela ABECIN contempla elementos de mediação, na linha proposta por Freire (1983), pois ela afirma que os processos de avaliação do ensino e das universidades ganham destaque e força, situando-se a avaliação como um elo efetivo entre a universidade e a realidade social.

A avaliação sendo vista como um elo efetivo entre a universidade e a realidade social concebe uma avaliação libertadora que não visa uma inserção na realidade, pois inseridos nela, nada almejamos modificar; mas visa sim à imersão na realidade mesma para

\footnotetext{
${ }^{26}$ Falamos aqui de uma educação que propicie a apropriação de informações, em contraposição a uma educação que se pautava na reprodução dos conteúdos transmitidos. A apropriação, além da apreensão dos conteúdos dialogados em sala de aula, propõe também a ação, ou seja, a apropriação já traz em sua derivação sufixal a palavra ação, daí ela ser contrária à reprodução.
} 
uma posterior emersão dessa realidade, como forma de, ou corroborar com o que está posto, ou de modificar o status quo vigente e promover uma educação que faça de seus sujeitos cidadãos plenos.

Uma educação voltada para o exercício da cidadania é buscada pela ABECIN e isso pode ser visualizado quando a mesma afirma que, contrapondo-se a esta visão de conhecimento como resultado e produto, há hoje uma tendência para ver e entender o conhecimento como processo, o que exige do aluno $e$ do professor capacidades $e$ competências diferentes. Para o aluno solicita, ao invés de memorização, capacidade de interpretação, de julgamento de sentido e de relação com o social e o vivido. Para os professores, exige pensar práticas pedagógicas que levem os alunos a fazer aproximações com o real, interpretá-lo e, através de suas ações, como sujeitos históricos, transformá-lo, atribuindo-lhe um novo sentido e significado. Percebendo o conhecimento como processo, a diretriz da ABECIN percebe-o como um elo entre os alunos e o professor; ou seja, os conhecimentos mediam os dois sujeitos do processo educativo. Neste sentido, o conteúdo acerca de mediação que está presente na proposta da ABECIN está relacionado com a conceituação de mediação de Paulo Freire, pois, para este, tanto as técnicas, quanto as teorias, mediatizam os sujeitos da educação; conceituação esta que também vai ao encontro da conceituação de Rasse (2000) para quem a mediação também é trabalho, práticas profissionais, técnicas e saber-fazer.

Podemos, portanto, afirmar que a ABECIN se contrapõe à visão de uma educação como mercadoria, quando afirma, indo ao encontro da pedagogia freiriana, que suas propostas educativas visam a que o aluno venha a desenvolver a capacidade de interpretação, de julgamento de sentido e de relação com o social e o vivido, fazendo com que a educação promova a convergência entre o mundo social e o mundo do trabalho, possibilitando, desta forma, uma educação renovada. Outra indicativa propõe ao professor levar os alunos a fazer aproximações com o real, interpretá-lo e transformá-lo, atribuindo novo sentido e significado, visão esta que segue uma perspectiva marxiana e, por conseguinte, freiriana, haja vista Paulo Freire ter se apoiado em Marx para formular muitas de suas teorias, principalmente, quando Freire afirma que a educação tem de estar em consonância com a realidade tendo em vistas transformá-la.

A observação de uma educação voltada para a realidade na qual os sujeitos do conhecimento estão inseridos está em consonância com a indicativa que afirma: apesar do modelo tecnicista ter marcado fortemente a formação do bibliotecário no Brasil, diante do desenho de um novo cenário, a área, neste momento histórico, procura romper com essa 
concepção de profissional eminentemente técnica. Esta afirmação propõe um novo modelo de formação de bibliotecários, pois se volvermos o olhar na perspectiva de encontro com o passado, perceberemos que ela retoma uma discussão histórica na área de Biblioteconomia, a qual, há muito, e com resquícios na contemporaneidade, esteve pautada, ora no modelo humanista de formação, ora no modelo tecnicista. Portanto, o que deve ser objeto de atenção nas escolas de Biblioteconomia/Ciência da Informação não é pender para um modelo formativo em detrimento do outro, mas sim, de reunir os dois modelos, técnico e humanista, tendo em vistas a práxis educativa. Desta feita, o que deve ser superado é a dicotomia entre a formação técnica e a formação humanista; entre os bibliotecários ligados à gestão da informação, com os bibliotecários mais ligados aos aspectos sociopolíticos da profissão, como forma de não dicotomizar a profissão entre os profissionais que se autodenominam de "pensadores," e aqueles que são denominados mais de "práticos", "técnicos".

Uma unidade de registro que propõe também não dicotomizar a teoria e a prática afirma que os cursos de graduação estão buscando, através de novas propostas curriculares, um perfil profissional de natureza mais interdisciplinar que possa dar conta de uma realidade heterogênea, em um tempo de rápidas, constantes e profundas mudanças, com um aparato tecnológico constantemente em aperfeiçoamento e com usuários cada vez mais exigentes. Quando os documentos da associação inserem em seu conteúdo e dão maior ênfase às informações que estão sendo constantemente produzidas e reproduzidas, parece afirmar que o bibliotecário irá trabalhar em organizações que privilegiam a novidade, a informação mais nova em detrimento até mesmo da memória, que é, por excelência, a base do seu fazer. É importante que se considere a dimensão das novas informações que são produzidas pela sociedade, porém, tão mais urgente quanto, é a preservação da memória, pois como se preserva a memória quando ela não mais está em determinado suporte e passa a ser fluxo? Como selecionar as informações que farão parte do arcabouço mnésico da sociedade num momento em que se vive um dilúvio de dados na rede e o que define o valor de uma informação é o seu critério de novidade? O que fazer com as memórias para que elas não se percam quando os homens morrerem? Daí a necessidade da dialogia entre as informações mais novas (que estão em permanente construção/reconstrução) e aquelas que são parte do acervo da tradição.

Provavelmente, a saída que a Biblioteconomia e a Ciência da Informação podem encontrar está em uma educação bibliotecária que não se admita somente transmissivista, mas sim, como forma de atender a essa exigência, o ensino de Biblioteconomia deve utilizar-se de novas aproximações didáticas e pedagógicas que permitam ir além do simples domínio 
cognitivo de conteúdos. Nesta concepção de ensino, a pesquisa atua como mola mestra da formação e da prática profissional, articulada com a extensão.

Persistindo e intensificando ainda mais nas questões concernentes aos processos avaliativos, o terceiro documento da ABECIN denomina-se Diretrizes para a Construção de Indicadores de Qualidade para a Avaliação de Cursos de Graduação de Biblioteconomia e Ciência da Informação. Este documento foi elaborado a partir da Oficina Regional de Trabalho Sul/São Paulo, sediada no Departamento de Ciência da Informação da UFSC, nos dias 18 e 19 de abril de 2002. Em primeiro lugar, é interessante observar que foi produzido um segundo documento tendo em vista dois aspectos cruciais dos princípios neoliberais pautados nas teorias tradicionalistas de currículo, a saber: qualidade e avaliação. Em relação à qualidade não é de se espantar que, num momento em que a escola é vista como um serviço, e a educação passa a ser vista como uma mercadoria, como qualquer outra no mercado, que os discursos acerca da qualidade total e avaliação na educação estejam na ordem do dia. Todavia, a qualidade que o neoliberalismo apregoa para o campo educacional refere-se aos princípios de produtividade e rentabilidade, fator este que introduz na escola o mecanismo da concorrência. Para que uma mercadoria tenha o selo da qualidade total é necessário que ela passe por vários processos avaliatórios, como forma de medir a sua qualidade.

A ligação estreita entre qualidade e avaliação dentro das indicativas da ABECIN pode ser verificada na unidade de registro para que seja possível discutir elementos atinentes a um processo de avaliação que se espera seja qualitativo, alguns aspectos inerentes do conceito de qualidade devem ser considerados: a) sua contextualização é necessária no sentido de se estabelecer uma ponte entre um modelo neoliberal meramente quantitativo vigente (e do qual não podemos fugir) e um modelo almejado, amplo, que contemple coerente e equilibradamente aspectos qualitativos e quantitativos; b) deve refletir os valores que nós esperamos que a sociedade veja expressa nessa avaliação; c) deve ser precedida por uma reflexão sobre a que sociedade nos referimos e sobre o papel da instituição nesse contexto. $\mathrm{Ou}$ seja, a contextualização deve estabelecer uma ponte entre o modelo neoliberal (quantitativo) e o modelo que se deseja (que equilibre qualidade e quantidade). Podemos, portanto, visualizar no conteúdo manifesto das recomendações da ABECIN a serviço de que a educação do bibliotecário deve estar pautada, pois, conforme afirma Sella (2002) a racionalidade apregoada pelo neoliberalismo é a pós-moderna, e está na medida do lucro, e não como algo intrínseco ao ser humano. 
Quando a indicativa afirma que não podemos fugir do modelo neoliberal embute nessa afirmação a ideia de que não se pode fugir de discutir esse modelo e, ao mesmo tempo, propor alternativas ao mesmo.

Embora as proposições da ABECIN afirmem que não podemos fugir da discussão dos preceitos de uma sociedade neoliberal (conforme o item (a) da categoria anteriormente citada - a sua contextualização é necessária no sentido de se estabelecer uma ponte entre um modelo neoliberal meramente quantitativo vigente (e do qual não podemos fugir)); ainda assim deixa uma porta aberta para que os cursos, em si, adotem uma postura de recusa e desenvolvam projetos pedagógicos e programas de disciplinas de forma a não corroborar com o que está posto. Este posicionamento pode ser percebido na seguinte proposição: $a$ concepção do profissional que se deseja deve ser revelada no projeto pedagógico do curso. $\mathrm{O}$ projeto pedagógico pode revelar a sua concepção de profissional por meio dos mecanismos de desenvolvimento do programa de disciplinas, dos laboratórios, onde os currículos possam vir a ter uma maior integração entre as disciplinas e de seus conteúdos, através da vivência, dentro da própria academia e, depois, pela busca do próprio aluno, nos estágios que são oferecidos pelo mercado. Essas ideias são complementadas por esta outra que afirma que: $a$ adequação e atualização das ementas e programas das disciplinas deve revelar o dinamismo inerente ao currículo (enquanto um transcurso). Um alerta, no entanto, se faz com relação às ementas, uma vez que estas têm sido, no decorrer dos últimos seis anos, um elo de harmonização entre os cursos de Biblioteconomia/Ciência da Informação do Mercosul. Nesse sentido, recomenda-se que a questão das ementas seja primeiramente discutida em nível macro, seja no espaço Mercosul, seja no espaço ABECIN. Acreditamos, sim, que o currículo deve ser atualizado como forma de não ficar alheio à sua realidade; mas, ao mesmo tempo, deve-se atentar ao fato de que "atualizar" tanto esse currículo pode vir a descaracterizá-lo. Ou seja, o currículo não pode continuar apenas constituído de categorias estanques (para usar expressões de Bauman, não pode ser um currículo "sólido", pois este tipo de currículo não dá conta daquilo que se espera da educação hodierna); mas também não deve ser um currículo "líquido", ou seja, um currículo que a cada novidade surgida, em quaisquer áreas de conhecimentos, principalmente, em relação às últimas inovações tecnológicas, deva se "adequar" a elas. A grande questão é como aliar os conhecimentos que herdamos da tradição (e que são importantes para se entender o momento pelo qual passa a Biblioteconomia na contemporaneidade), e os conhecimentos que estão sendo produzidos atualmente (por meio dos investimentos em pesquisa em nível de Pós-Graduação na Ciência da Informação). O 
currículo deve ser, sim, um aparelho dinâmico, mas, em concomitância, deve preservar os conhecimentos que herdamos da tradição.

Retomando o pensamento de Bauman, em relação aos conceitos de sólidos e líquidos, podemos perceber que, embora seja importante nos tempos hodiernos que a educação trate dos conhecimentos que estão emergindo, também é necessário que ela se paute nos conhecimentos já consolidados pela tradição. Daí a importância de se saber elaborar um PPP tendo em vistas a simbiose entre os dois tipos de modelos formativos. É nesse sentido que foi elaborado o quarto documento no âmbito da ABECIN e que se denomina Avaliação do Processo Formativo na Área de Biblioteconomia/Ciência da Informação: documento referencial. Este documento foi elaborado a partir da Oficina Regional de Trabalho Norte/Nordeste, realizada no VI Seminário Nacional de Avaliação Curricular, em FortalezaCE, no dia 27 de junho de 2002.

Este documento também visa auxiliar os cursos a elaborar seus Projetos Pedagógicos. Para tanto, delimita quais os componentes que devem estar presentes nos mesmos, quais sejam: apresentação, justificativa, princípios norteadores, objetivos, perfil dos formandos, estrutura curricular, estágios e atividades curriculares complementares (neste item deve conter ementário, objetivos, conteúdo programático, metodologia do trabalho, formas de avaliação, bibliografia básica e complementar), estrutura do curso e avaliação do curso. Portanto, além de traçar diretivas, a ABECIN discutiu, juntamente com outros professores, cada elemento do PPP para que as escolas a posteriori construíssem seus PPPs e os programas de disciplinas. Podemos perceber que este é, também, o quarto documento da ABECIN que tem uma preocupação mais voltada para os aspectos avaliativos tanto do currículo, quanto para a avaliação do processo formativo dos alunos.

Outra ênfase encontrada nos documentos da ABECIN está relacionada à Gestão da Informação e que é abordada em seu quinto documento o qual se denomina: I Seminário Pedagógico ABECIN "Gestão da Informação". Neste documento apresentam-se as áreas curriculares e a carga horária que seria dispensada a cada uma, conforme disposto a seguir: 1) Fundamentos Teóricos da Biblioteconomia e Ciência da Informação-14\%; 2) Organização e Tratamento da Informação- 20\%; 3) Recursos e Serviços de Informação- 20\%; 4) Tecnologias de Informação- 16; 5) Gestão da Informação- $20 \%$ e 6) Pesquisa- 10\%. Conforme podemos observar, as áreas que concentram maior carga horária referem-se à Organização e Tratamento da Informação, Recursos e Serviços de Informação e Gestão da Informação, o que transparece uma maior importância dada aos processos de gestão e tratamento da informação. As porcentagens dedicadas às áreas de fundamentação teórica e da 
pesquisa são as que contêm menor carga horária, o que pode caracterizar uma formação majoritariamente técnica para a formação do bibliotecário.

Também podemos pensar nessas porcentagens em relação aos contextos regionais, pois há áreas do País que foram pouco ou nada industrializadas e que a economia gira em torno do setor primário, sendo forte a agricultura, a pecuária e o extrativismo. Então, como enfatizar a formação do bibliotecário conforme essas porcentagens, as quais enfatizam a Gestão e os Recursos e Serviços de Informação, principalmente, numa região que não tem um setor industrial forte, mas sim, seu aspecto cultural? Onde ficam contempladas as questões relativas à mediação da cultura nas áreas curriculares da ABECIN? Numa região em que o setor cultural é tão forte, como na Norte, como ficaria contemplada a mediação da cultura desse local? Em qual área curricular? Onde está contemplada a formação do bibliotecário enquanto um agente de transformação social, enquanto um mediador? Como se chegou a essas porcentagens? O que se observa aqui é que mesmo tendo a indicativa afirmado ser importante levar em conta os contextos específicos de cada região, ela fixa carga horária para as áreas curriculares sem levar em conta o contexto de cada região brasileira.

Em relação à mediação informacional e cultural não encontramos uma área curricular que esteja explicitamente voltada para as questões concernentes à mediação. Por que tanta ênfase nos processos técnicos e na gestão da informação e não citar a mediação e a ação cultural, que são, também, campos de atuação do bibliotecário? Em que área curricular essas questões estão contempladas? Elas estão contempladas? Acreditamos ser importante que houvesse a criação de uma área curricular para tratar dos aspectos relacionados à mediação (informacional e cultural), haja vista que elas possibilitariam uma maior discussão acerca da dimensão cultural e educativa do profissional da informação/bibliotecário, mas não apenas em forma de diálogos, mas sim, em forma de dialog-ação, como nos coloca Paulo Freire.

Outra questão a ser colocada refere-se à carga horária das disciplinas relacionadas à pesquisa. Por que apenas $10 \%$, se as disciplinas da área de pesquisa poderiam servir de ponto de intersecção de todas as outras áreas curriculares numa perspectiva transdisciplinar? $\mathrm{Na}$ realidade, todas as disciplinas, conforme sugerem as diretrizes do MEC, podem ter a pesquisa como um dos pilares de sua consecução. No entanto, a ênfase da formação do bibliotecário vem se dando na Gestão da Informação, como forma de “capacitar os estudantes na gestão competente, para atuar em sistemas e unidades de informação e em todo tipo de organizações e contextos, com atitude proativa", e como objetivo específico "ser capaz de planejar, implementar, dirigir, coordenar e avaliar sistemas e unidades de informação com visão estratégica”. Esta ênfase dá-se numa sociedade que mercadoriza todos 
os tipos de conhecimentos e, no caso da informação, este processo não vem se efetivando de forma diferente.

Podemos perceber, portanto, que não há indicativas de que este documento se preocupa com o gerenciamento da informação tendo em vista a mediação da informação como forma de buscar a significação da informação nos sujeitos. Uma significação que busque uma imersão nas informações, como forma de impulsionar os sujeitos para a ação, para o exercício pleno de sua cidadania. No entanto, encontramos a seguinte diretriz: nesse sentido, foi mencionada a necessidade de disciplinas da área de Administração, assim como a importância do estabelecimento de uma integração maior entre a administração e a computação (tecnologias de informação e comunicação), uma vez que o ambiente informacional é muito dinâmico e o valor da informação no contexto informacional é uma realidade. Desse modo, a formação visando competências e habilidades, nesta área curricular, é fundamental. Portanto, a ênfase deste documento recai nos processos de gerenciamento da informação, o que poderá vir a desaguar nos conteúdos dos PPPs dos cursos de Biblioteconomia.

Mais um documento da ABECIN que têm sua ênfase na avaliação denomina-se Auto-avaliação do ensino no Brasil desde a perspectiva da pesquisa, extensão e gestão: contribuição para um modelo de avaliação de escolas de Biblioteconomia e Ciências da Informação do Mercosul. Este documento foi elaborado pela Comissão de Redação, composta pelos professores: Msc. Mara Eliane Fonseca Rodrigues (Presidente da ABECIN); Profa. Dra. Miriam Vieira Cunha, (Vice-Presidente da ABECIN); Prof. Dr. José Augusto Guimarães (Coordenador Regional da ABECIN); Profa. Dra. Marta Ligia Valentim (Membro do Conselho Consultivo da ABECIN) e Prof. Dr. Osvaldo Francisco de Almeida Júnior (Membro da ABECIN). Este, portanto, foi o primeiro documento da ABECIN onde encontramos, mais claramente, a preocupação com a perspectiva da transdisciplinaridade, propondo que a mesma esteja inserida nos currículos. Este fato pode ser visualizado quando se afirma que a ABECIN assume como sendo estratégico substituir o paradigma da disciplinaridade, que até agora conduziu o padrão de ensino e aprendizagem no ensino de graduação da área de Ciência da Informação, pelo de interdisciplinaridade elou transdisciplinaridade.

É nesse sentido da auto-avaliação que todo o documento em lide foi elaborado. Consta, neste documento, uma breve análise acerca da educação brasileira em nível superior, apresenta a política nacional de ensino de graduação e a estrutura do ensino de graduação na área de Ciência da Informação, avalia o perfil dos profissionais da informação, o mercado de 
trabalho, os processos de avaliação e ensino nas universidades, a política de capacitação docente, a política de pesquisa e a política de extensão.

Continuando sua preocupação com a avaliação, o último documento elaborado no âmbito da ABECIN denomina-se Oficina Pedagógica Região Sudeste: (re)construção das práticas pedagógicas no processo de ensino-aprendizagem em ciência da informação. Esta oficina foi realizada na UNIRIO, com o apoio da Universidade Federal Fluminense, realizada no Rio de Janeiro nos dias 6 e 7 de dezembro de 2004. Neste documento discutiu-se o desafio de ser professor universitário, o conceito de ensino-aprendizagem, o entendimento de prática pedagógica, o conceito de aula universitária, as experiências didático-pedagógicas vividas pelos professores e a articulação teoria-prática no processo ensino-aprendizagem.

Para a reconstrução/ressignificação dos cursos de Biblioteconomia, este documento afirma que o ensino de graduação, para possibilitar a inserção profissional nessa nova realidade, exige a construção de relações com o conhecimento que levem ao efetivo domínio de seus fundamentos e não apenas à assimilação das possíveis aplicações momentâneas. Portanto, podemos perceber a preocupação da ABECIN com os conhecimentos que estão na pauta das discussões, mas que não somente os conteúdos que são emergentes, pois assim, não se tem um eixo formativo para os profissionais da informação.

Em relação ao processo formativo em sala de aula, o documento conclui que o professor se constrói em um processo coletivo, educando-se com os parceiros de atividade docente no seu espaço de trabalho, na interação com os outros. No coletivo se desenvolvem vínculos de confiança e solidariedade, contribuindo para um clima de convívio rico e estimulador. Valoriza-se, assim, a experiência de cada professor, resgatando a sua identidade pessoal e profissional, permitindo a construção coletiva de saberes. Portanto, é uma indicativa de que o processo formativo em Biblioteconomia deve ser realizado com base na dialogia entre professores e alunos, sendo mediados pela realidade ao seu redor, como forma de contextualizar o processo formativo.

\subsection{Caminho analítico do currículo do Curso de Biblioteconomia da UFPA}

A história do Curso de Biblioteconomia da Universidade Federal do Pará não se deu de forma tranquila. Primeiro, sua instituição ocorreu por acolhimento à proposição do Reitor José da Silveira Neto pelo Conselho de Curadores, por meio da Resolução n ${ }^{\circ} 1$-A, de 28/01/1963. A criação do Curso de Biblioteconomia satisfez a exigência fundamental dos reclames da sociedade em geral e da própria Universidade, em particular. Da sociedade, 
porque, em Belém, ainda que com a existência de duas entidades tradicionais de pesquisa - o Museu Goeldi e o Instituto Agronômico do Norte - seis escolas superiores oficiais, quatro particulares, além da Biblioteca e Arquivo Público e bibliotecas de instituições privadas, havia apenas uma bibliotecária, não obstante a existência de bibliotecas nessas instituições. Da Universidade, porque havia constituído a sua Biblioteca Central que iria servir de fulcro a toda a atividade acadêmica no campo da informação bibliográfica. $\mathrm{O}$ novo Curso atenderia ao desenvolvimento da comunidade universitária.

A Biblioteca Central era ela mesma, uma instituição sem funcionários diplomados em Biblioteconomia. Para a sua fundação haviam prevalecido as leis da necessidade e da urgência, através da diplomação, em cursos de especialização, de profissionais vinculados a outras áreas de conhecimento, deslocados para o Instituto Brasileiro de Bibliografia e Documentação (IBBD) pelo prazo de um ano. Afora estes, a massa de pessoal para os serviços técnicos, havia sido formada em curso rápido de treinamento.

A análise do currículo do Curso de Biblioteconomia do Pará é importante por este ser um dos cursos mais antigos da Região Norte do País e, por isso, ter tradição no ensino de Biblioteconomia no Brasil. É importante frisar que tentamos por diversas vezes ter acesso aos programas das disciplinas do currículo em lide, porém não tivemos acesso a elas, nem por meio da comunicação mediada por computador, nem pessoalmente, haja vista termos ido à coordenação do curso, e ao CAC (Coordenadoria de Avaliação e Currículo) de ensino da universidade e não termos obtido êxito. Portanto, depois dessas tentativas, buscando na Internet algum caminho que nos levasse a algum programa de disciplina para vermos como eles eram elaborados, encontramos um programa da disciplina Leitura e Competência Informacional, a qual estava inserida no $\operatorname{blog}^{27}$ da disciplina de mesmo nome, que é mantido pelo professor Rubens da Silva Ferreira.

Analisando a constituição do programa da disciplina em questão (que foi a única que tivemos acesso, conforme falamos anteriormente), o que é denominado de conteúdo programático são os mesmos itens do ementário. Portanto, a partir desses dados, inferimos que os conteúdos programáticos se constituem da mesma forma que o texto dos ementários de cada disciplina, não havendo, portanto, diferença entre um e outro no contexto do currículo do curso de Biblioteconomia da UFPA, diferentemente do que ocorre em outros currículos, a exemplo da UNB, USP, UFC e UFSC. Outra questão que é importante frisar é que a própria

\footnotetext{
${ }^{27}$ Disponível em: <http://leituraecompetenciainformacional.blogspot.com/>. Acesso em:26 set. 2011.
} 
ABECIN (2002) no seu quarto documento intitulado Avaliação do Processo Formativo na área de Biblioteconomia/Ciência da Informação: documento referencial, delineou como componentes do Projeto Político Pedagógico os seguintes elementos: 1) Apresentação (esclarecimento da proposta pedagógica construída); 2) Justificativa (o que e porque se vai fazer); 3) Princípios norteadores (fundamentação filosófica, epistemológica e pedagógica); 4) Objetivos; 5) Perfil dos Formandos; 6) Estrutura curricular; 7) Estágios e Atividades complementares (o programa dos cursos devem conter: ementário, objetivos, conteúdo programático, metodologia do trabalho; forma(s) de avaliação; bibliografia básica e complementar). Nesse sentido, percebemos que o currículo da UFPA ficou mais distante do nosso modelo ideal.

O currículo desta universidade propõe para os futuros bibliotecários uma formação baseada na compreensão crítica e democrática da universalização e direito à informação de todas as camadas sociais; no comportamento ético; na independência e liberdade de aprender e ensinar, pesquisar e disseminar a informação e o conhecimento, nas variadas formas em que se apresentam, como a cultura, o saber, o pensamento, a arte, etc.; no compromisso com a cidadania; na contextualização política, social e econômica, dentro de uma perspectiva amazônica. A informação neste contexto é vista como um patrimônio da humanidade e, como tal, deve ser processada para o uso comum. Portanto, neste conteúdo, está expressa a categoria da mediação, tanto cultural quanto informacional, se visualizarmos a mediação no sentido de Veillette (2008), ou seja, como um ato que não é neutro, haja vista que é a cultura quem interpela e faz mediação. Se não há um mediador neutro, então, o acesso à informação que se apresenta em forma de cultura também não é neutra, pois, só são socialmente aceitáveis e reconhecidas as culturas constitutivas de uma identidade comum, caso contrário, elas são socialmente negociadas, conformadas, de modo a não entrar em conflito. É nesse sentido que Veillette (2008) afirma não haver um mediador neutro, se é a cultura quem faz mediação, daí também não podermos falar de um intermediário neutro, haja vista serem os mediadores quem administram a distribuição dos fluxos de informação, até mesmo os culturais. Por outro lado, cada leitor é tanto produtor, quanto consumidor de seu próprio espaço de fluxos informacionais, e, com a informação cultural, este processo não vem se efetivando de forma diferente. Com as TICs, as formas de mediação cultural vêm se transformando, pois não é mais necessário irmos fisicamente aos mais diversos locais para conhecer as mais diversas culturas, pois muita informação já está presente na rede. Nessa perspectiva as TICs também são um espaço privilegiado não apenas para exercer o poder, mas também, para a integração cultural, tendo em vista que, se há algum tempo as trocas culturais 
para se efetivarem necessitavam de que o polo A se deslocasse até o polo B para conhecer a cultura do "outro"; na contemporaneidade, essas trocas se efetivam no ciberespaço. As TICs vêm efetivando a aproximação entre as diferentes culturas.

Neste contexto, é importante atentar para uma educação transcultural para a formação do bibliotecário, pois se a interculturalidade buscaria levar a novíssimas Tecnologias de Informação e de Comunicação para uma comunidade que não a utiliza buscando a negociação cultural, ela também poderia propiciar que uma cultura A fosse até a cultura B apenas para buscar algumas informações unicamente para prover informação, como incita García Canclini (2007); a transculturalidade, como estamos trabalhando desde o início de nossas discussões com este prefixo, trata de perceber o que está através e além das culturas.

Além de possibilitar essa formação mais humanista e cultural, o curso ainda busca formar profissionais para dominar os meios necessários, incluindo tecnologias de informação, que lhe permitirão otimizar o trabalho de seleção, organização, processamento, recuperação e disseminação da informação, o que nos possibilita pensar numa formação que alia a teoria à prática dos formandos; que estejam informados sobre os recursos informacionais em seus diferentes suportes e formatos, nas diversas áreas do conhecimento, o que possibilita a que o bibliotecário saiba como identificar e como tratar os produtos documentários das mais diversas áreas de conhecimentos; que identifiquem as necessidades de informação dos indivíduos e da sociedade na qual está inserido, o que lhe facilitará o planejamento e a implementação de solução de problemas de informação da sociedade contemporânea. Portanto, nesta unidade de registro estão inseridas as categorias da mediação da informação, em sua forma de práticas profissionais, conforme afirma Caune (2000) e que estão sendo transformadas em seu fazer pelas TICs, haja vista, que, na contemporaneidade, muitas vezes está ocorrendo o processo de desintermediação, pois, com as TICs, os usuários vão direto às informações que se encontram na rede.

O PPP da UFPA possui conteúdos que vêm ao encontro daqueles da ABECIN que enfatizam o lado de gestor do profissional da informação/bibliotecário, quais sejam: elaborar, coordenar, executar e avaliar planos, programas e projetos na área da Biblioteconomia e Ciência da Informação. Quando o PPP faz esta afirmação percebemos que busca a ampliação do leque de atuação do bibliotecário, haja vista que esse profissional pode vir a desenvolver quaisquer projetos na área de Biblioteconomia e Ciência da Informação, tanto na área de planejamento de ambientes de mediação de informações, quanto de elaboração e administração de projetos culturais. 
Outra unidade de registro do currículo do Curso de Biblioteconomia da UFPA que vem ao encontro da formação de um bibliotecário gestor refere-se a assessorar projetos arquitetônicos e de engenharia destinados ao espaço físico da unidade de informação. Nesta unidade de registro encontra-se implícita a ideia da transdisciplinaridade, pois não tem como se ver as fronteiras dos conhecimentos, pelo contrário pode-se perceber certa dialogia entre os profissionais da arquitetura e da engenharia com o profissional da informação. Esta unidade de registro vai ao encontro daquelas que propõem: elaborar orçamentos financeiros de unidades, serviços e sistemas de informação; administrar sistemas de segurança patrimonial e de acervos de unidades, redes e sistema de informação; planejar, implantar e administrar unidades, redes, sistemas e serviços de informação em consonância com a missão e os objetivos da instituição a que estejam vinculados; administrar o compartilhamento de recursos informacionais, por meio de associações, consórcios e alianças. São, portanto, unidade de registro que visam a uma melhor gestão das unidades de informação e à segurança das mesmas, mas não apenas destas, mas também das redes e do sistema de informação. Outras unidades de registro que vão ao encontro da formação de um bibliotecário gestor são aquelas que buscam que o bibliotecário saiba promover política de desenvolvimento de coleções em qualquer suporte; planejar e executar estudos de usuários de informação em vista do aperfeiçoamento de serviços e produtos de informação; trabalhar em equipe de modo cordial e cooperativo; planejar, implementar e gerir processos de informatização de unidades de informação; avaliar unidades, produtos, serviços e sistemas de informação; avaliar desempenho de pessoas em unidades, redes e sistema de informação; conduzir projetos de pesquisa orientados à verificação do uso da informação para a solução de problemas relacionados ao trabalho com a informação; aplicar técnicas de marketing às instituições bibliotecárias e a produtos e serviços de informação; empreender atividades bibliotecárias de modo autônomo; orientar, dirigir, assessorar, prestar consultoria, realizar perícias e emitir laudos técnicos e pareceres em Biblioteconomia e Ciência da Informação.

Também encontramos outras unidade de registro no currículo do Curso de Biblioteconomia da UFPA que vão ao encontro da formação de bibliotecários mediadores/educadores, quais sejam: planejar e implementar projetos voltados para a formação de usuários da informação, ou seja, formar usuários que sejam autônomos frente à utilização dos recursos informacionais, usuários que saibam utilizar-se das ferramentas de busca e recuperação da informação a fim de que eles mesmos encontrem a informação desejada em bibliotecas, arquivos, museus e outros lugares onde se pode buscar a informação (daí a necessidade de se ensinar a "desintermediação" da informação). Outras unidade de 
registro que apontam para a formação de bibliotecários mediadores referem-se aquelas que afirmam que buscam formar bibliotecários aptos a identificar oportunidades de aplicação das teorias biblioteconômicas na solução de questões informacionais; demarcar campos específicos e integrar conteúdos de áreas correlatas em uma perspectiva multidisciplinar, pois os alunos formados em Biblioteconomia dispõem das técnicas que aprendem em seus cursos para aplicar em quaisquer locais que tenham informações que precisam ser disponibilizadas.

A unidade de registro anteriormente citada vem ao encontro das seguintes: analisar fluxos de informações para fins do desenvolvimento de produtos e serviços de informação; ser efetivo no uso da comunicação na gestão de unidades de informação; selecionar, avaliar, representar, organizar e difundir seletivamente a informação para usuários de unidades, serviços e sistemas de informação. Estas vão ao encontro da formação de um bibliotecário mediador de informações, que tem um papel estratégico na sociedade, qual seja, de analisar as informações, desenvolver produtos e serviços que visem à facilitação do acesso às informações que são fluxos, tendo em vistas o uso dessas informações por parte dos usuários dos ambientes de mediação de informação. Para tanto, é necessário que o bibliotecário saiba definir quais são as suas práticas de mediação da informação e, também, tenha conhecimentos acerca da recepção de informações por parte dos usuários, daí a necessidade de estudos acerca da estética da recepção. A significação das informações em quaisquer ambientes de mediação de informação está ligada às condições sócio-históricas e o mundo mediaria as informações para o indivíduo significá-las.

O que é interessante nesse currículo é que, mesmo sem uma pós-graduação na área de informação, o currículo do curso tem uma linguagem aberta ao paradigma da informação, não ficando restrito apenas ao paradigma do documento e abre as possibilidades de atuação do profissional da informação/bibliotecário. Podemos verificar tal fato quando se afirma que, no curso em análise, ao final de sua formação, se tem um profissional capaz de agir em qualquer instituição, pública ou privada, bancárias ou comerciais, como fóruns, cartórios, arquivos, museus, centros de restauração de documentos, empresas de comunicação, editoras, gráficas, livrarias, centros de análise de informação, nos campos de pesquisa ou docência e em bibliotecas.

Embora tenhamos encontrado uma unidade de registro a qual afirma que a educação do bibliotecário na UFPA está baseada na independência e na liberdade de aprender e ensinar, em outro momento ela corrobora aquilo que a ABECIN afirma também para a formação do bibliotecário, ou seja, que ela fundamenta-se nos pilares da educação 
contemporânea: aprender a ser, a fazer, a conviver e a conhecer, visando à melhoria da condição humana, bem como da capacidade do aluno em buscar por meios próprios seu crescimento pleno, integral e continuado. Este fato evidencia, portanto, que o currículo do curso de Biblioteconomia da UFPA tem em algumas indicativas da ABECIN as bases de sua elaboração e fica mais próximo do modelo ideal.

Neste sentido, assim como estão presentes nas propostas da ABECIN, o PPP da UFPA também possui sua ênfase nos processos de Gestão da Informação, conforme pode ser visualizado nas unidades de registros que pautam o perfil, as competências e habilidades desse profissional: ter capacidade de aplicação dos fundamentos, princípios e técnicas de gestão, o que lhe favorecerá o ótimo uso dos recursos humanos, materiais e financeiros disponíveis, bem como os meios de ampliá-los; elaborar, coordenar, executar e avaliar planos, programas e projetos na área da Biblioteconomia e Ciência da Informação; assessorar projetos arquitetônicos e de engenharia destinados ao espaço físico da unidade de informação, dentre outras competências e habilidades que são totalmente voltadas para os processos de Gestão da Informação. O que o currículo da UFPA nos deixa bem claro é a sua ênfase na Gestão da Informação, e este fato talvez seja resultado de uma ênfase das indicativas da ABECIN na unidade curricular de Gestão da Informação, tendo um documento específico para que sejam elaboradas as diretrizes dessa área. Ou seja, a UFPA parece em sintonia com as determinações da ABECIN e deu uma maior ênfase nos processos de Gestão.

Outra questão em que transparece a sintonia do Curso de Biblioteconomia da UFPA com a ABECIN foi a ênfase nos processos avaliativos dos alunos, conforme pode ser visto na unidade: o Curso de Biblioteconomia da UFPA privilegiará, por meio de seus docentes, a avaliação como um processo/instrumento de acompanhamento, mediação, diálogo e intervenção mútua entre o ensino e as aprendizagens. Este processo avaliativo deverá corrigir o rumo das ações, retroalimentando e reorientando a prática, por meio da reflexão contínua, bem como, buscar a conscientização dos educandos de seu percurso acadêmico, possibilitando um olhar crítico dos próprios avanços e necessidades, fazendo com que se sintam responsáveis por suas atitudes e aprendizagem. A ênfase do currículo da UFPA encontra-se nas unidades de Organização da Informação (23\%), Recursos e Serviços de Informação (23\%) e Gestão de Unidades e Serviços de Informação (23\%). Já as áreas de Fundamentação Teórica da Biblioteconomia e Cultura e Formação Geral recebem cada uma $11 \%$ e $20 \%$, respectivamente. Deste fato podemos perceber que o currículo da UFPA ainda não superou a velha dicotomia do currículo humanista ou técnico, que a Biblioteconomia discute desde a sua gênese no Brasil. Portanto, a ênfase do currículo de Biblioteconomia da 
UFPA está nos processos de Organização e Gestão da Informação, ficando os conteúdos relativos à formação geral e fundamentação teórica da área mais marginalizados.

Realizando uma análise comparativa (Quadro 5) da carga horária dedicada às áreas curriculares, tanto pela ABECIN, quanto pela UFPA, pudemos observar que a ABECIN confere uma maior ênfase às disciplinas voltadas ao processamento técnico da informação e das disciplinas voltadas à gestão de unidades de informação, o que contabilizam, juntas, $60 \%$ da carga horária do curso. Esse percentual não leva em conta as disciplinas voltadas às tecnologias de informação, pois elas podem vir a ter um cunho mais humanista das tecnologias, ou podem vir a dar apoio às disciplinas da área de Gestão da Informação. Já o projeto pedagógico da UFPA não segue exatamente as áreas curriculares propostas pela ABECIN no I Seminário Pedagógico ABECIN Gestão da Informação, e também não segue a carga horária dispensada para cada unidade.

Quadro 6- Comparação percentual das áreas curriculares da ABECIN e da UFPA

\begin{tabular}{|l|l|}
\hline \multicolumn{1}{|c|}{ Área curricular (\%) ABECIN } & \multicolumn{1}{|c|}{ Área curricular (\%) UFPA } \\
\hline $\begin{array}{l}\text { 1) Fundamentos Teóricos da Biblioteconomia e } \\
\text { Ciência da Informação- 14\% }\end{array}$ & $\begin{array}{l}\text { 1) Fundamentação Teórica da } \\
\text { Biblioteconomia-11\% }\end{array}$ \\
\hline $\begin{array}{l}\text { 2) Organização e Tratamento da Informação- } \\
\mathbf{2 0 \%}\end{array}$ & 2) Organização da Informação-23\% \\
\hline 3) Recursos e Serviços de Informação-20\% & 3) Recursos e Serviços de Informação-23\% \\
\hline 4) Tecnologias de Informação-16\% & $\begin{array}{l}\text { 4) Gestão de Unidades e Serviços de } \\
\text { Informação-23\% }\end{array}$ \\
\hline 5) Gestão da Informação-20\% & 5) Cultura e Formação Geral-20\% \\
\hline
\end{tabular}

Fonte: Pesquisa documental.

Comparando o percentual de disciplinas distribuídas em cada área curricular, podemos perceber as diferenças em relação às indicativas da ABECIN. Em primeiro lugar, há menor ênfase na fundamentação teórica da área da Biblioteconomia, e a Ciência da Informação não é citada como área curricular. Já às áreas de Organização e Tratamento da Informação, Recursos e Serviços de Informação e Gestão da Informação a ABECIN propôs que fossem distribuídas no currículo $20 \%$ respectivamente da carga horária do currículo nas disciplinas dessas áreas. Todavia, a UFPA aumentou em 3\% a carga horária nas unidades de 
Organização da Informação; Recursos e Serviços de Informação e Gestão de Unidades e Serviços de Informação, ficando cada área com $23 \%$.

Todavia, mesmo não seguindo as diretrizes da $\mathrm{ABECIN}$ no que concerne à porcentagem das cargas horárias das disciplinas em cada unidade curricular, a UFPA ainda segue as tendências propostas pela associação no que diz respeito à maior ênfase nas disciplinas voltadas para a gestão e o tratamento técnico da informação, pois as áreas de Organização da Informação, Recursos e Serviços de Informação e Gestão de Unidades e Serviços de Informação contabilizam, juntas, o total de 66\% da carga horária do curso (6\% a mais do que propõe a ABECIN), em detrimento das áreas de Fundamentação da Biblioteconomia e Cultura e Formação Geral que, juntas, contabilizam 31\%, ou seja, $8 \%$ a menos do que propõe a ABECIN.

A unidade de Tecnologia da Informação e Pesquisa não foi contemplada no currículo da UFPA, o que pode ser decorrência do fato de que eles diluíram a abordagem das TICs nas variadas disciplinas do currículo (o que pudemos perceber, também, ao analisar o programa das disciplinas). Na realidade, o próprio MEC afirma que as disciplinas de Metodologia da Pesquisa e Tecnologia poderiam ser diluídas no currículo, e na página do curso de Biblioteconomia da UFPA, afirma-se que o emprego de tecnologias, o domínio da linguagem oral e escrita, a metodologia da pesquisa científica e a metodologia de ensino serão utilizados, de forma transversal, em todas as áreas e atividades, de modo a contribuir para o desenvolvimento do espírito investigativo e inovador, bem como, favorecer a autonomia no processo de aprendizagem e no mundo do trabalho (UFPA, 2009).

Em relação ao currículo da UFPA podemos perceber que ele sofreu bastante influência da Sociedade da Informação, principalmente, no que concerne à inserção das TICs no conteúdo explícito do texto curricular, as quais alteraram os processos mediacionais da informação e da cultura. Portanto, este currículo trata de forma explícita, no seu conteúdo manifesto, das questões concernentes à mediação da informação e tratam essas questões tanto de forma mais tradicional, quanto de forma mais contemporânea, realizando uma simbiose entre os dois modelos. Também ficou ressaltada, nesse currículo, a formação não apenas de um bibliotecário técnico-organizador, mas também de um bibliotecário que pensa que as técnicas de tratamento e de organização de informações são utilizadas tendo em vistas à mediação e o acesso às informações.

\subsection{Caminho analítico do currículo do Curso de Biblioteconomia da UFSC}


O Curso de Biblioteconomia da UFSC está vinculado ao Centro de Ciências da Educação, tendo sido implantado em 1973 com o nome inicial de Curso de Biblioteconomia e Documentação. Recebeu o reconhecimento do Conselho Federal de Educação, em 8 de novembro de 1977, através do Parecer n. 3.129 confirmado pelo Decreto Presidencial de n. 81.144 publicado no Diário Oficial da União em 2 de janeiro de 1978. Desde 1978, passou a ser denominado Curso de Biblioteconomia. Tem oferta de oitenta vagas anuais, sendo quarenta para ingresso no primeiro semestre e quarenta para o segundo semestre de cada ano.

O currículo do Curso de Biblioteconomia da Universidade Federal de Santa Catarina, cujo PPP foi elaborado pelos professores Araci Isaltina de Andrade Hillesheim, Estera Muszkat Menezes, Magda Chagas Pereira, Marta Elizabete Zanatta, Miriam Vieira da Cunha e pelos alunos Fabiano Caruso e Gláucia Maindra da Silva. Diferentemente do currículo do Curso de Biblioteconomia da UFPA, o Projeto Político Pedagógico estava disponível na página $w e b$ deste curso.

Por meio da análise do Projeto Político Pedagógico do Curso de Biblioteconomia da UFSC percebemos que a sua concepção do projeto pedagógico pressupãe uma reflexão sobre o conceito de educação defendido pelo curso e sua relação com a sociedade. Podemos perceber que este curso busca não formar apenas profissionais competentes tecnicamente nas mais variadas técnicas de processamento da informação, mas também, que sejam profissionais aptos para lidar com os mais diferentes contextos sociais da realidade brasileira. Busca, portanto, aliar, conforme nos lembram as palavras de Paulo Freire (1959), a formação profissional com a realidade brasileira e biblioteconômica. Portanto, o curso busca abordar estas novas funções [que] aparecem ao mesmo tempo nos ambientes de trabalho "clássicos" do bibliotecário (bibliotecas, centros de documentação e informação) e em novos ambientes como os diferentes "universos" da Internet (entre os quais estão vídeos, filmes, músicas, documentos textuais, homepages, listas de discussão, softwares, padrões e protocolos), as editoras, as livrarias, as videotecas, as gerências de informação para negócios e os centros de atendimento ao cidadão, entre outros. Neste currículo percebemos uma ampliação dos campos de atuação do bibliotecário para quaisquer ambientes que tenham informações, registradas ou não, a serem produzidas, coletadas, organizadas com fins de uso; portanto, percebemos que, também no campo curricular, o bibliotecário não é mais apenas o profissional que organiza e armazena para mediar o acesso, mas é, sobretudo, o criador, o arquiteto de informações.

No tocante à atuação do bibliotecário, o texto curricular do curso de Biblioteconomia da UFSC afirma que sua missão é capacitar profissionais capazes de refletir 
sobre a realidade e reconstruir o conhecimento com vistas ao progresso humano, tendo como referência as competências fundamentais da Biblioteconomia. Portanto, preocupa-se em aliar a teoria e a prática dos formandos, futuros profissionais, antenados com a realidade ao seu redor, e com os diferentes espaços sociais. Outra questão interessante a se ressaltar é que este currículo cumpre aquilo que Paulo Freire propôs para a educação brasileira, ou seja, que ela não tratasse dos conhecimentos como algo estanque, acabado, mas sim que tivesse a ideia do conhecimento como algo em permanente construção, fazendo-se e refazendo-se pelos sujeitos.

Nesse sentido, o objetivo geral do curso é formar bibliotecários com uma visão crítica da sociedade, capazes de atuar como profissionais da informação imbuídos do compromisso com a gestão da informação e sua disseminação e com consciência do seu papel social na eliminação de barreiras de acesso à informação, seja de natureza política, tecnológica, econômica, educacional, social, cultural e recreativa. Desta feita, busca formar um bibliotecário que tenha consciência crítica de seu papel social, principalmente, no que concerne ao acesso à informação, a qual é o objetivo precípuo dos processos de mediação do fazer bibliotecário. O papel do bibliotecário neste currículo é atuar como profissional não apenas da organização da informação, mas sim, da coleta, da elaboração, da organização e de criar mecanismos de buscas e de recuperação de informações, visando à mediação e o acesso às informações por parte dos usuários. Uma questão importante a discutir acerca desta unidade de registro é visualizar que todo processo de tratamento, organização e mediação tem como objetivo precípuo o acesso à informação por parte dos usuários.

Pensando nos usuários e nos processos mediacionais, os quais, conforme Caune (2000) também são técnicas e saber-fazeres, os objetivos específicos do curso referem-se a que o bibliotecário saiba processar a informação registrada em diferentes tipos de suportes e que é uma diretriz do MEC, a qual este currículo cumpre fidedignamente em seu conteúdo. Outro objetivo específico refere-se a aplicar conhecimentos teóricos e práticos de gestão no planejamento e funcionamento de unidades de informação, o que pressupõe a formação de um bibliotecário plural, ou seja, formado não apenas competentemente no tratamento e na organização da informação, mas também, na gerência dos ambientes de mediação da informação. Outra unidade de análise que vem ao encontro da anterior refere-se a que o bibliotecário venha gerir atividades de seleção, análise, armazenamento e difusão da informação, ou seja, atividades que, há algum tempo, já vêm sendo realizadas por este profissional, principalmente, a partir da Idade Moderna com a laicização das bibliotecas. Esses trabalhos também eram realizados quando do surgimento das bibliotecas públicas, que 
visam não apenas à guarda do patrimônio bibliográfico-documental de determinada sociedade, mas também, que visa à mediação de informações e de culturas no ambiente biblioteconômico.

Além desta visão de um bibliotecário gestor, neste currículo há a visão de um bibliotecário mediador, haja vista ele buscar formar um bibliotecário que saiba realizar pesquisas relativas a produtos e serviços e, para isso, este profissional tem de saber lidar com as mais variadas técnicas de pesquisa acerca dos mais variados produtos e serviços documentários. Além disso, o currículo de Biblioteconomia da UFSC busca formar um profissional que saiba utilizar as técnicas de processamento, transferência e uso da informação, a fim de realizar os processos de mediação e possibilitar o acesso à informação para o indivíduo e/ou grupo com o qual trabalha e que saiba atuar como estimulador $e$ orientador no uso de recursos informacionais através de ações e programas de educação de usuários. Estas diretrizes estão em consonância com aquelas do MEC para a formação de bibliotecários, as quais preveem não apenas um bibliotecário que atue como gestor e como organizador do volume documentário-informacional, mas também um bibliotecário que utiliza as mais variadas ferramentas que possibilitem a mediação das informações presentes em quaisquer ambientes de mediação de informação. Outra questão a que este currículo se propõe é ensinar ao bibliotecário a dominar as tecnologias de informação para uso em serviços de informação, tendo em vistas a que ele saiba gerenciar a implantação de programas de informatização em unidades de informação. Nestas duas últimas diretrizes podemos perceber que este currículo visa também à formação de um bibliotecário empreendedor.

Outra diretriz formativa do currículo do Curso de Biblioteconomia da UFSC diz respeito a ver o currículo como um mecanismo que sempre estará aberto para contemplar a dinâmica da sociedade. Neste sentido, incorpora estratégias de inserção de Tópicos Especiais e de estudos individualizados, como forma de complementar a formação oferecida nas diferentes disciplinas que constituem a grade curricular. O que encontramos de bastante interessante neste currículo são as disciplinas denominadas de Tópicos Especiais, pois elas vêm dar conta dos conhecimentos que estão sendo construídos e reconstruídos, constantemente, pelos homens. Portanto, essas disciplinas possibilitam estudar os assuntos que estão "na ordem do dia" da Biblioteconomia e da Ciência da Informação, sem incorrer no risco de ficar criando disciplinas para novos tipos de conhecimentos que podem vir a ser efêmeros e que podem deixar o currículo com uma carga muito grande de disciplinas. 
Outra questão importante também concernente às disciplinas denominadas de Tópicos Especiais é que elas se parecem muito com a proposta freiriana para a educação brasileira, ou seja, de que os educadores têm de ouvir os educandos na escolha do conteúdo programático da educação. Os educadores têm de elaborar um currículo que tenha determinada sequência e determinada historicidade para que os alunos possam saber da historicidade da área de conhecimento que está estudando e na qual atuará como profissional; mas esse mesmo currículo também deve ser dialético a ponto de também contemplar os novos saberes que são produzidos pela comunidade científica e pela própria sociedade. Portanto, concordamos com Hannah Arendt quando a mesma afirma que a educação deve ser conservadora e, também, concordamos com Paulo Freire quando ele afirma que a educação deve dar conta da realidade socio-histórica na qual ela está inserida, ou seja, acreditamos que o currículo deva ser dialético. O próprio currículo de Biblioteconomia da UFSC afirma que as disciplinas denominadas de Tópicos Especiais possibilitará ao aluno uma inserção no contexto da profissão, desde as primeiras fases do curso, fazendo com que ele compreenda o papel e as responsabilidades do bibliotecário utilizando-se do conhecimento teórico, da vivência em unidades de informação (bibliotecas, centros de informação, centros de documentação) e do contato com profissionais que se encontram no exercício da profissão.

O currículo também propõe a interação do aluno com a comunidade, ou seja, este princípio tem por fundamento a necessidade de não alienar o estudante em relação ao seu meio. Será viabilizada a partir de atividades que envolvam a iniciação científica, a participação em projetos de extensão, a produção de trabalhos monográficos e as atividades de estágio que busquem associar o interesse da formação acadêmica com a ação em campo. Portanto, percebemos que busca a interação entre as teorias e as práticas efetivas dos alunos em campo, como forma de que o aluno vivencie, desde o início de sua formação, os saberesfazer de sua prática profissional. Todavia, há que se ter cuidado para não acabar fazendo desse aliamento entre teoria e prática apenas um treinamento dos alunos para as práticas profissionais (haja vista nos ter falado Paulo Freire que apenas o treinamento nada tem a ver com formação), mas sim, fazer dessas práticas uma verdadeira práxis. Portanto, o que o curso de Biblioteconomia da UFSC propõe para a formação do bibliotecário refere-se a que a experiência se torne uma espécie de autorreflexão e autocrítica e, por meio dessas categorias, que se busque uma nova práxis profissional, verdadeiramente, transformadora. Busca-se, também, por meio de uma educação que não seja pautada apenas nos palavreados, numa educação verbosa, onde os alunos vivenciam a sua prática profissional buscando, encontrar 
novos projetos existenciais ${ }^{28}$ e que não fiquem pautados apenas naqueles que já são tradicionais.

Pensando em um currículo que seja práxis, o curso de Biblioteconomia da UFSC afirma que o novo currículo foi pensado em função do seguinte perfil profissional, com três especificidades: gestor de unidades de informação; técnico no tratamento da informação e educador no uso de recursos informacionais. Analisando estas unidades de registro podemos afirmar que o currículo da UFSC busca formar um profissional que seja não apenas um gestor, um técnico, ou um educador, mas sim, que possa atuar nessas três dimensões com a mediação da informação. Portanto, podemos perceber que o currículo busca formar um bibliotecário mediador de informações e de culturas haja vista que o gerenciamento, o tratamento técnico e a educação de usuários na competência informacional são três fatores que são indissociáveis nos ambientes de mediação de informação.

Em relação às competências técnico-científicas que o aluno formado desenvolverá, encontramos: desenvolver e executar o processamento de documentos em distintos suportes em unidades, sistemas e serviços de informação e elaborar produtos de informação (bibliografias, catálogos, guias, índices, Disseminação Seletiva da InformaçãoDSI, etc.), ou seja, o bibliotecário não fica mais restrito apenas ao processamento técnico dos documentos, mas, é protagonista na produção de informações. Todavia, se volvermos o olhar na perspectiva de encontro com o passado encontraremos Calímaco, o bibliotecário grego, que organizou a Biblioteca de Alexandria, e elaborou produtos documentários, a saber, o catálogo da referida biblioteca. Com o desenvolvimento da Biblioteconomia, que deu subsídios para o desenvolvimento da Documentação e esta para a Ciência da Informação, os suportes informacionais apenas foram se modificando, mas a essência dos livros e dos documentos, que é a informação, continua a mesma.

A diretriz supra-analisada está relacionada com aquela que afirma que outra competência do bibliotecário é selecionar, registrar, armazenar, recuperar e difundir a informação gravada em qualquer meio, para os usuários de unidades, serviços e sistemas de informação. O que podemos ver é que a partir desta diretriz o campo de atuação do bibliotecário é ampliado, haja vista que o mesmo poderá atuar em quaisquer empresas que

\footnotetext{
${ }^{28}$ Nesse sentido, acreditamos que a educação não deve ser apenas propiciadora dos saberes teóricos de cada disciplina e área do conhecimento, mas deve, sobretudo, ser praxiológica na vida do estudante de modo que aquilo que o estudante esteja vivenciando em sala de aula e aprendendo teoricamente esteja em consonância com seus projetos de vida. É daí que a educação tem que ser realizada também nos fazeres da prática profissional e, que no caso da formação em Biblioteconomia, a prática seja realizada nos mais diferentes ambientes informativo-mediacionais, propiciando a construção dos estudantes da Biblioteconomia, mas não em um modelo único de formação, mas dando conta da pluralidade dos ambientes de mediação de informação em que esse estudante poderá vir a atuar.
} 
tenha alguma informação a ser tratada tendo em vistas a sua organização, mediação e acesso. Por exemplo, em hospitais tratando a informação médica em prontuários eletrônicos de pacientes; ou com a informação ambiental, elaborando produtos documentários acerca da informação ambiental e dando suporte às escolas, movimentos sociais, projetos institucionais, empresas (principalmente, quando estas visam aos selos de responsabilidade socioambiental), ou seja, privilegiando a mediação da informação no seu cotidiano.

Outra competência técnico-científica refere-se a reunir $e$ avaliar documentos $e$ proceder ao seu arquivamento; buscar, registrar, avaliar e difundir a informação com fins acadêmicos e profissionais; executar procedimentos automatizados próprios de um ambiente informatizado e realizar pesquisas e estudos sobre desenvolvimento e aplicação de metodologia de elaboração e utilização do conhecimento registrado. Portanto, o bibliotecário está cada vez mais apto a criar e manter arquivos digitais, montar bancos de dados em computadores empregando as mais modernas TICs, como bancos de dados digitais e a Internet. Utiliza, portanto, a informação tendo em vistas a que a linguagem utilizada nos sistemas de informação seja cada vez mais adequada com a linguagem dos profissionais da área, com o sistema de organização das informações dos sistemas de informação.

Portanto, o que se pode perceber nesse currículo, é que ele propõe a atuação de bibliotecários, também entendidos como profissionais da informação, em quaisquer ambientes que tenham dados a ser organizados, os quais possam fazer sentido para o usuário, ou seja, passe a ser informação. Esses ambientes que têm informação para ser gerenciada podem ser bibliotecas, centros de documentação, centros de informação utilitária, na elaboração de trabalhos científicos, na análise das informações e dos seus fluxos em quaisquer fontes de informação. Por meio da utilização do conhecimento registrado, o bibliotecário poderá atuar na criação, sistematização dos conhecimentos tácitos e explícitos das empresas, por exemplo, como forma de divulgar a sua memória e a própria missão e objetivos das empresas.

Como competências gerais, o bibliotecário formado pela UFSC saberá dirigir, administrar, organizar e coordenar unidades, sistemas e serviços de informação, ou seja, será um bibliotecário que saberá não apenas tratar dados tendo em vistas a sua organização e mediação, mas também, saberá gerenciar quaisquer ambientes de mediação da informação.

Outra competência refere-se a formular e gerenciar projetos de informação; assessorar no planejamento dos recursos econômico-financeiros e humanos do setor; planejar, coordenar e avaliar a preservação e conservação do acervo documental; planejar e executar estudos de usuários da informação e programas de formação de usuários da informação; planejar, constituir e administrar redes regionais e globais de informação. 
Nestas unidades de registro podemos visualizar uma maior predominância dos conteúdos relativos à gestão de unidades de informação, em detrimento daquelas relativas à mediação de informações. As que se referem às questões mediacionais inserem as TICs como coadjuvantes nesse processo, pois, os mecanismos de mediação passam a ser quase-interações, haja vista que os usuários vão interagir com os conteúdos dos meios, conforme afirma Thompson (2002).

Como competências sociais e políticas, o bibliotecário formado pela UFSC saberá assessorar e intervir na formulação de políticas de informação, tendo em vistas ações culturais e informacionais nas comunidades onde atuará. Neste caso, o bibliotecário não apenas acompanha as políticas de informação, mas também, é um sujeito agente na promoção das políticas informacionais e, portanto, um mediador de informações e de culturas. Também é uma das propostas do currículo de Biblioteconomia da UFSC que o bibliotecário saiba promover uma atitude crítica e criativa a respeito da resolução de problemas e questões de informação. A partir destas propostas, o bibliotecário não é mais visto como um "guardião do saber", conforme nos mostra a história da Biblioteconomia e das bibliotecas, mas é visto como um sujeito que interfere nas questões informacionais no ambiente onde está inserido, promovendo mecanismos de mediação de informação para as comunidades. Para que ele possa fomentar uma atitude aberta e interativa com os diversos atores sociais (políticos, empresários, educadores, trabalhadores e profissionais de outras áreas, instituições e cidadãos em geral), é necessário que ele saiba quais são as demandas informacionais da comunidade na qual está inserido, daí a necessidade de o bibliotecário realizar estudos de comunidades e de usuários de informação, a fim de saber quais são as demandas informacionais da comunidade.

Outra questão que o currículo da UFSC propõe para a formação de bibliotecários refere-se a que o mesmo saiba processar a informação registrada em diferentes tipos de suportes, o que vai ao encontro das diretrizes educacionais do MEC para a formação de bibliotecários. Este fator também é decorrente das transformações oriundas da Sociedade da Informação, haja vista que foi a partir do período pós-segunda guerra mundial, que ocorreram as mais diversas transformações nos suportes informacionais e nas formas de informação e de comunicação presentes na sociedade. Outra questão refere-se a aplicar conhecimentos teóricos e práticos de gestão no planejamento e funcionamento de unidades de informação, o que pressupõe a formação de um bibliotecário gestor de unidades de informação, que saiba as mais variadas formas de administração para que possa gerenciar o ambiente de mediação de informação na qual está inserido. 
O bibliotecário também é o profissional habilitado a gerenciar atividades de seleção, análise, armazenamento e difusão da informação; realizar pesquisas relativas a produtos e serviços, processamento, transferência e uso da informação; dominar as tecnologias de informação para uso em serviços de informação; gerenciar a implantação de programas de informatização em unidades de informação e todas estas atividades estão relacionadas à atuação de bibliotecário gestor nos ambientes de mediação de informação. $\mathrm{O}$ que podemos perceber é que todas essas habilidades dos bibliotecários estão voltadas para o bibliotecário atuar como estimulador e orientador no uso de recursos informacionais através de ações e programas de educação de usuários, ou seja, atuar como um mediador de informações, independentemente, se o suporte ainda estiver no formato analógico, ou já for digital. Portanto, cumpre o que no início do Projeto Político Pedagógico do Curso de Biblioteconomia da UFSC afirma, ou seja, a formação de bibliotecários como gestor de unidades de informação; técnico no tratamento da informação e educador no uso de recursos informacionais.

Em relação ao fluxo de informações do currículo, podemos perceber pelo seu próprio conteúdo que ele não tem um fluxo interrompido a cada semestre, como se nos apresentou o currículo do curso de Biblioteconomia da UFPA, embora mescle disciplinas de cunho mais teórico com as mais técnicas. O próprio conteúdo curricular afirma que se procurará ordenar as diferentes disciplinas, de forma a que os conteúdos sejam apresentados em ordem crescente de aprofundamento, respeitando o nível de conhecimento anterior do aluno.

Quadro 7- Comparação das áreas curriculares ABECIN e UFSC
\begin{tabular}{|l|l|}
\hline \multicolumn{1}{|c|}{ ABECIN } & \multicolumn{1}{|c|}{ UFSC } \\
\hline $\begin{array}{l}\text { 1)Fundamentos Teóricos da } \\
\text { Biblioteconomia/CI- 14\% }\end{array}$ & $\begin{array}{l}\text { 1)Disciplinas instrumentais- } \\
\text { 20,58\% }\end{array}$ \\
\hline $\begin{array}{l}\text { 2)Organização e Tratamento } \\
\text { da Informação- 20\% }\end{array}$ & $\begin{array}{l}\text { 2) Fundamentos de } \\
\text { Biblioteconomia e CI- } \\
\text { 11,77\% }\end{array}$ \\
\hline $\begin{array}{l}\text { 3)Recursos e serviços de de Organização e Tratamento } \\
\text { informação- 20\% }\end{array}$ & $\begin{array}{l}\text { 3) Orgac } \\
\text { da Informação- 17,65\% }\end{array}$ \\
\hline $\begin{array}{l}\text { 4)Tecnologia da Informação-- } \\
\text { 16\% }\end{array}$ & $\begin{array}{l}\text { 4) Recursos e Serviços de } \\
\text { Informação- 11,76\% }\end{array}$ \\
\hline $\begin{array}{l}\text { 5)Gestão da Informação-- } \\
\text { 20\% }\end{array}$ & $\begin{array}{l}\text { 5) Gestão da Informação- } \\
\text { 29,41\% }\end{array}$ \\
\hline 6) Pesquisa- 10\% & 6) Monografia- 5,88\% \\
\hline & 7) Estágio- 2,95\% \\
\hline
\end{tabular}

Fonte: Pesquisa documental. 
Comparando as porcentagens entre a ênfase das áreas curriculares e a porcentagem de disciplinas que será destinada a cada área, podemos perceber que a área de Fundamentação Teórica da Biblioteconomia e da Ciência da Informação no currículo proposto pela própria ABECIN propõe a destinação de 14\% das disciplinas obrigatórias. Já o currículo da UFSC destina a esta área $11,77 \%$ das suas disciplinas. Um pouco mais que a UFPA, porém, ainda abaixo daquilo que propõe a ABECIN; todavia, se agregarmos a esta porcentagem aquela que foi destinada às disciplinas instrumentais, ou seja, 20,58\%, e considerarmos estas disciplinas instrumentais, quais sejam: Comunicação, Inglês Instrumental, Produção Textual, Introdução à Sociologia para Biblioteconomia, Relações Humanas, Teoria Geral da Administração, Estatística Aplicada, como disciplinas que auxiliam a fundamentação teórica acerca da área, então essa porcentagem salta para 32,35\%, ou seja, 18,35\% a mais do que sugere a ABECIN e o currículo da UFSC teria a sua ênfase na fundamentação teórica e cultural da área de Biblioteconomia e Ciência da Informação.

À área de Organização e Tratamento da Informação no currículo da UFSC estão destinados $17,65 \%$ das disciplinas obrigatórias, já o da ABECIN sugere $20 \%$ das disciplinas. Podemos perceber que a UFSC reduziu a quantidade de disciplinas destinada a esta área curricular, em relação ao que sugeria a ABECIN (enquanto, como visto anteriormente, a UFPA aumentou a quantidade de disciplinas desta área curricular; este fato evidencia a tendência do currículo da UFPA para as disciplinas práticas da Biblioteconomia/Ciência da Informação e a tendência do currículo da UFSC para uma formação menos técnica e mais teórica e cultural em seu currículo).

A área de Recursos e Serviços de Informação no currículo da UFSC representa um total de $11,76 \%$ das disciplinas obrigatórias do curso, o que a ABECIN já propõe que seja $20 \%$.

A área de Tecnologias da Informação no currículo da UFSC representa 0\%, ou seja, ela não está representada como disciplina isolada, porém, se analisarmos os conteúdos das disciplinas (o que não é o objetivo deste trabalho), podemos perceber que este currículo seguiu o que as diretrizes do MEC propõem, ou seja, que os conteúdos relativos à Metodologia da Pesquisa ou às Tecnologias de Informação e de Comunicação podem ser objetos de atividades praticadas no âmbito do conteúdo de uma, ou mais disciplinas, de modo transversal. Neste quesito este currículo realizou a mesma ação que o currículo da UFPA, ou seja, não delimitou disciplinas específicas para a área de Tecnologias de Informação, tendo ficado com $0 \%$ também. No entanto, a ABECIN propõe que $16 \%$ das disciplinas curriculares sejam da área de Tecnologias da Informação, o que nos leva a pensar que, a forma como os 
dois currículos buscaram inserir os conhecimentos teóricos e práticos acerca das TICs, foi diluída nas disciplinas, o que é muito mais interessante, haja vista que permite que esses conhecimentos estejam no âmbito de várias disciplinas e não apenas concentrada em uma ou duas.

À área curricular denominada de Gestão da Informação no âmbito da ABECIN são dedicados $20 \%$ das disciplinas do currículo, e no âmbito do currículo da UFSC dedicamse $29,41 \%$ das disciplinas obrigatórias. Podemos perceber que, neste currículo, há praticamente uma equivalência entre as disciplinas de cunho mais teórico, com as disciplinas de cunho mais prático, pois as áreas de Disciplinas Instrumentais, Fundamentos de Biblioteconomia e Ciência da Informação, Monografia e Estágio, juntas, somam um percentual de $41,18 \%$ e as disciplinas das áreas de Organização e Tratamento da Informação, Recursos e Serviços de Informação e Gestão da Informação juntas totalizam 58,82\%, ou seja, $17,64 \%$ a mais que as disciplinas tidas como teóricas.

A área curricular denominada de Pesquisa no âmbito da ABECIN recebe um total de $10 \%$ das disciplinas e no currículo da UFSC ela se denomina de Monografia e recebe $5,88 \%$ do conjunto das disciplinas que se relacionam a elas. No currículo da UFSC existe a área curricular denominada de Estágio e recebe 2,95\% das disciplinas relacionadas a ela e é uma área que não está presente naquelas classificadas pela ABECIN.

A grade de disciplinas no currículo de formação do bibliotecário na UFSC é um fluxo segmentado entre teoria e prática, haja vista que cada semestre está sempre mesclado de disciplinas de cunho mais profissional e outras de cunho mais teórico; portanto, o currículo alia a teoria e a prática até mesmo na construção das disciplinas; embora seja uniforme em relação ao ordenamento das disciplinas de forma a que os conteúdos estejam em ordem de aprofundamento. Todavia, do quarto ao sétimo semestre há disciplinas de cunho mais técnicoprofissionais concentradas, sem haver mescladas nelas disciplinas de cunho mais teórico. A não-uniformidade dessa distribuição pode ser decorrente, também, do atual contexto técnicocientífico e informacional.

Inicialmente, nossas hipóteses apontavam para que os cursos que possuíssem pósgraduação na área de Ciência da Informação tivessem uma pendência para disciplinas de cunho mais teórico, haja vista que as técnicas da Biblioteconomia, embora possam ser transmitidas nas mais variadas disciplinas, os alunos conseguem dimensionar os conhecimentos dessas disciplinas apenas quando da realização dos estágios. Portanto, percebemos, por meio de uma visualização das grades de disciplinas dos currículos dos Cursos de Biblioteconomia da UFPA e da UFSC, que eles continuam ainda bastante técnicos 
e este fato pode ser decorrente dos encaminhamentos propostos pelos documentos da ABECIN, pois os mesmos dão uma maior ênfase aos processos de gestão de informações e de unidades de informação, tendo, portanto, elaborado um documento à parte para tratar das disciplinas dessa unidade. Portanto, são disciplinas que buscam inserir os novos conhecimentos no currículo, entretanto, sem colocar à margem os conhecimentos mais tradicionais do campo da Biblioteconomia e da Ciência da Informação.

\subsection{Caminho analítico do currículo do Curso de Biblioteconomia da UNB}

O ensino de Biblioteconomia nasceu, na Universidade de Brasília (UnB), com a criação da própria Universidade: o Plano Orientador da Universidade de Brasília previa o acesso, à Faculdade de Biblioteconomia, de bacharéis egressos dos Institutos Centrais de Ciências, Letras e Artes, que prosseguissem em direção ao curso de Graduado em Biblioteconomia, destinado à formação de bibliotecários especializados nas várias áreas do saber. Este pretensioso projeto original de educação do bibliotecário na UnB, moldado nos melhores padrões norte-americanos, por demasiado oneroso e por requerer longo período de formação, veio logo a ser abandonado.

A UnB, instituída pela Lei $\mathrm{n}^{\circ}$. 3.998, de 15 de dezembro de 1961, teve o Plano Orientador editado como primeiro lançamento da sua Editora já em 1962, no mesmo ano em que se regulamentava, no Brasil, a profissão do bibliotecário. Como consequência da regulamentação da Biblioteconomia como profissão de nível superior, foram criados órgãos de classe e foi aprovado um Currículo Mínimo nacional, específico do curso superior de Biblioteconomia. A conjugação destes fatos deu ensejo, em 1965, à criação do curso de Graduação em Biblioteconomia, em nível de Bacharelado, com a duração de três anos, na Faculdade de Biblioteconomia e Informação Científica (FUBICA). O currículo pleno deste curso incorporou, desde logo, uma formação técnica, ligada às atividades da documentação, que focalizava, de forma pioneira no Brasil, a incipiente mecanização e automação das bibliotecas.

Este, portanto, é o terceiro curso que faz parte das nossas análises e é um caso particular, pois o Curso de Biblioteconomia da UNB não realizou as alterações curriculares demandadas pelo MEC em todo o seu currículo, mas fez apenas algumas alterações pontuais no ano de 2006, além de não ter realizado a alteração no seu PPP depois da última alteração curricular proposta pelo MEC em 2001; portanto, o PPP que vamos analisar data de novembro de 1997. 
Cabe esclarecer que, por mais que em nossa formulação do problema, tenhamos dito que iríamos analisar apenas os currículos a partir da reforma proposta pelo MEC, a análise do currículo da UNB não invalida nosso trabalho haja vista que o mesmo realizou algumas alterações pontuais no currículo, que é o que é demandado pelo MEC, ou seja, o Curso de Biblioteconomia em questão alterou o seu currículo no que diz respeito às disciplinas (conteúdo programático, ementa, bibliografia) e alterou algumas nomenclaturas das disciplinas, porém não houve alterações substanciais.

Portanto, o currículo da UNB realizou a sua revisão em 1992 e, dentro do projeto de revisão do currículo pleno do curso de Graduação em Biblioteconomia, cinco Grupos Temáticos foram formados pelos docentes do Departamento de Ciência da Informação e Documentação da Universidade de Brasília - CID/UNB, quais sejam: Fundamentação, Planejamento e Gerência, Representação Descritiva, Representação Temática e Consolidação). Todavia, mesmo com a análise de revisão curricular, não chegou a se implantar um novo currículo, embora tenham sido estabelecidos alguns princípios organizadores. Dentre os princípios organizadores estão: a adaptação à formação do profissional em função da realidade do mercado, que exige maior ênfase em: catalogação, classificação, indexação e uso dos recursos informacionais. O que podemos perceber é cada vez mais a educação está organizando os seus conteúdos tendo por base as demandas provenientes das mutações do mercado. Nesse mesmo sentido, cursos são criados, outros são extintos no âmbito das universidades públicas, as quais deveriam buscar a preservação da pluralidade dos conhecimentos. Portanto, é nesse contexto que percebemos no âmbito das universidades públicas que esse mesmo mercado vem definindo quais cursos devem ser criados, quais devem ser extintos e quais pesquisas devem ser financiadas. Neste ínterim, o PPP contempla o mercado como a principal mediação no interior do currículo, ou seja, o mercado é o elo entre os conhecimentos criados pela sociedade e o mundo em que esses conhecimentos são mediados e recriados, ou seja, a universidade. A questão que colocamos aqui se refere a que, uma formação voltada estritamente para os anseios do mercado de trabalho por si só, não tem sentido nem legitimidade, pois o sentido das universidades vai além da sua função econômica, haja vista que ela também tem um sentido social, que não deve ser esquecido.

Em relação ao tipo de formação que o curso de Biblioteconomia da UNB busca contemplar está o equilíbrio entre os aspectos básicos ou "núcleos/módulos" do currículo: a) formação básica ou fundamentação; b) habilidades gerenciais, c) habilidades do bibliotecário profissional, d) habilidades do documentalista profissional, bem como e) visão 
integrada e consolidada dos serviços informacionais. Nesse sentido, achamos equivocada a expressão dos itens c e d, pois quais seriam as atividades do bibliotecário profissional e quais seriam as habilidades do documentalista profissional? Se remontarmos à história da Biblioteconomia e da Documentação podemos perceber já no livro de Suzanne Briet $O$ que é a documentação que a autora afirmara que em sua viagem aos Estados Unidos entre $1951 \mathrm{e}$ 1952 que os serviços de bibliotecas especializadas naquele País eram bastante parecidos com os centros de documentação franceses, porém com outra denominação. Se no contexto francês houve uma divisão entre bibliotecários e documentalistas, nos Estados Unidos os bibliotecários exerciam as funções da biblioteca pública e especializada. Narra a história, que somente na década de 1960 os pesquisadores que se preocupavam com leitura, documentação, história do livro, mídias e cultura apresentavam dificuldades em encontrar reconhecimento em suas próprias disciplinas, foi nesse sentido que Escarpit, Meyriat e Barthes, dentre outros, formaram o Comitê de Ciências da Informação e da Documentação ${ }^{29}$. Portanto, a denominação Ciência da Informação surgiu como forma de dar um aspecto científico às áreas que desde a Antiguidade já atuavam no campo da informação, a exemplo da Biblioteconomia, da Arquivologia e da Museologia. Todavia, há autores como Souza, F. (2007) que afirma que a mudança na denominação destas três áreas, em especial a da Biblioteconomia é uma tentativa dos idealizadores de rejuvenescê-las, principalmente, por não conhecerem mais profundamente os fundamentos epistemológicos dessas áreas. Nesse sentido, devido a toda a historicidade da Biblioteconomia e da Documentação que elas não podem ser vistas de forma separada, mas sim, de forma complementar uma à outra, pois tratam dos mesmos tipos documentários, entretanto, tiveram contextos de desenvolvimentos no final do século XIX de forma diferente e em lugares diferentes, daí a diferenciação das terminologias em Biblioteconomia Especializada e Documentação, mas ambas, em seu desenvolvimento, acabaram por tratar dos mesmos assuntos.

Nesse sentido que o curso de Biblioteconomia da UNB percebe a formação de bibliotecários, vistos não apenas como profissionais que tratam de livros, mas de mídias e interações informativas, portanto são profissionais que, por essência, são mediadores de informação. Com esta visão, a fim de instrumentalizar o curso de Graduação em Biblioteconomia, em nível de Bacharelado, a formar bibliotecários que venham a se constituir em profissionais da informação habilitados para o exercício de sua missão social, propõe-se um currículo que ofereça um meio ambiente de imersão integral nas tecnologias

\footnotetext{
${ }^{29}$ Para maiores detalhes cf. Ortega (2009).
} 
da informação, enquanto instrumentos convencionais da ação profissional do bibliotecário. Podemos perceber que a área da Biblioteconomia tanto trabalha com técnica quanto com tecnologia, ou seja, técnicas são os procedimentos ligados a uma arte ou ciência, como por exemplo, as primeiras formas de organização do conhecimento, as formas de se fazer os materiais de informação; já tecnologias são aqueles conjuntos de conhecimentos que se aplicam a um determinado ramo de atividade, não apenas as formas de fazer, mas os objetos já feitos, como por exemplo, os livros são tecnologias, as classificações dos conhecimentos, as formas de organização mais contemporâneas, dentre outros, pois possuem conhecimentos incorporados. Nesse sentido, a Biblioteconomia, tanto trabalha com técnicas, quanto com tecnologias, as quais são técnicas mais conhecimentos incorporados ${ }^{30}$.

Uma unidade de registro interessante a se observar neste currículo refere-se à afirmação de que a formação em Biblioteconomia da UNB visa a formar bibliotecários que caracterize a informação como todo conhecimento humano inscrito sob qualquer forma, $e$ considere que a gestão desses recursos do universo da informação, far-se-á independentemente de sua origem, de seu suporte material e de sua instituição depositária, portanto, o tipo de informação citada refere-se à informação documentária, ou seja, aquela informação registrada em quaisquer suportes. Se a informação de que trata a Biblioteconomia e a Ciência da Informação é a informação registrada, então, podemos afirmar que as informações registradas no cérebro humano e que constituem a sua memória são fontes de informação e objetos de trabalhos dos bibliotecários. Ou seja, o trabalho dos bibliotecários se pauta não somente na mediação de informação, mas também na organização da memória humana, de forma dialógica.

Se a memória humana é fonte de informação para o trabalho e o pensar dos profissionais da informação/bibliotecários, então está aí um nicho de atuação desses profissionais, ou seja, com a documentação da memória humana em empresas, constituindo documentos sobre o conhecimento tácito dos empregados; nas cidades documentando a memória de seus habitantes para que a própria história do espaço social não se perca. Nesse sentido é que se encontra a importância de estudos transdisciplinares e que o próprio currículo atue na transdisciplinaridade. Portanto, o currículo da UNB visa com esse tipo de informação mnésica que ela também amplie a interdisciplinaridade no segmento curricular reservado à formação diversificada do profissional de Biblioteconomia (disciplinas optativas e do módulo

\footnotetext{
${ }^{30}$ Para maiores detalhes cf. CHAUÍ, Marilena; MATOS, Olgária. A contração do tempo e o espaço do espetáculo. 2010. Disponível em: <http://www.cpflcultura.com.br/site/2010/09/03/cafe-filosofico-cpflespecial-\%E2\%80\%93-a-contracao-do-tempo-e-o-espaco-do-espetaculo-\%E2\%80\%93-marilena-chaui-eolgaria-matos/>. Acesso em: 28 de nov. 2011.
} 
livre) para permitir que, numa interação ampla com o universo pedagógico disponível em toda a universidade, o futuro profissional da informação possa assimilar uma formação teórica e uma habilidade metodológica holística.

No sentido de uma visão holística para a formação de bibliotecários, o curso afirma que privilegia a iniciação à pesquisa científica como atividade curricular queadministrada através do restabelecimento da orientação acadêmica (de que participem todos os membros do corpo docente do curso)- possa ser vivenciada ao longo de todo o curso por parte de discentes e docentes, de forma a propiciar também aos professores uma oportunidade adicional de capacitação científica e pedagógica. Nesse momento percebemos o foco orientador da formação do bibliotecário na UNB, ou seja, um bibliotecário pesquisador, engenheiro e tecnólogo, portanto, um bibliotecário que busca conhecer a sua área, por meio da pesquisa podendo enveredar-se na carreira acadêmica, um bibliotecário engenheiro, no sentido de criar sistemas de informação, os centros de mediação de informação, os produtos documentários e o bibliotecário tecnólogo, aquele que aplica os conhecimentos e os produtos criados. Todavia, não visa à sobreposição de nenhum desses três, até mesmo porque eles serão trabalhados no interior do currículo em simbiose.

O Projeto Pedagógico do Curso de Biblioteconomia da UNB ainda está em construção e por isso buscamos historicizar um pouco esse processo.

No dia 17 de novembro de 1997 o CID encaminhou aos colegiados da Faculdade de Estudos Sociais aplicados a proposta de alteração curricular o projeto, o qual foi composto de histórico, objetivo das alterações do currículo, síntese das alterações curriculares (9 páginas), equivalência entre o currículo mínimo e pleno e anexo ao Regimento Geral da Universidade de Brasília, formulário de criação de disciplina, formulário de programa/ementa de disciplina, fluxo do curso, listagem com especificações gerais de disciplinas, equivalência entre disciplinas, estágio supervisionado e quadro demonstrativo com as principais diferenças entre o currículo atual e o proposto.

A 20 de novembro de 1997 a proposta recebeu aprovação da Congregação de Carreira acompanhando parecer amplamente favorável da relatora. No dia 8 de dezembro de 1997, a Comissão de Avaliação da Reforma Curricular dos Cursos da UnB aprovou o projeto ora em análise. No dia 9 de dezembro, também sem restrições, a Câmara de Ensino de Graduação aprovou o projeto. No dia 19 de dezembro, com o visto da Diretoria de Administração Acadêmica (DAA), o processo foi encaminhado ao CEPE (Conselho de Ensino Pesquisa e Extensão). 
Em 2005, foi formada uma comissão composta pelos professores Sofia Galvão Baptista (Presidente da Comissão- Chefe do Departamento do CID), Tarcisio Zardonade (Coordenador do Curso de Biblioteconomia), Renato Tarcísio de Sousa (Coordenador do Curso de Arquivologia), Rogério Henrique Junior (Arquivologia), Antonio Lisboa de Miranda (Biblioteconomia) e os alunos Catarina Félix Soares (Centro Acadêmico de Biblioteconomia) e Wallace Saldanha (CA de Arquivologia) para comporem a Comissão de Revisão Curricular dos Cursos de Graduação em Biblioteconomia e Arquivologia do CID da UNB. Em 2008, foi demandado pela então coordenadora do Curso de Biblioteconomia do CID, Profa. Dulce Baptista, que se eliminasse do currículo todas as disciplinas optativas que nunca foram cursadas pelos alunos.

Portanto, os bibliotecários formados pela UNB poderão atuar em centros de informação, institutos de pesquisas, bibliotecas, videotecas, provedores de informação, empresas, pinacotecas, bancos, museus, centros culturais, hemerotecas, entre outros. Assim, o mercado de trabalho abrange a área pública (poderes executivo, legislativo e judiciário), bem como os diferentes setores produtivos (setor bancário, telecomunicações, setor agrícola, setor têxtil, saúde). Além disso, um dos mercados emergentes volta-se para o profissional autônomo. Em 2009 foi lançado um esboço do fluxograma de disciplinas obrigatórias, mas ainda não foram realizadas as alterações no PPP, nem mesmo alterações no fluxograma do currículo, apenas alterando o conteúdo das disciplinas.

Quadro 8 - Áreas e Disciplinas do Curso de Biblioteconomia da UNB ${ }^{31}$

\begin{tabular}{|c|c|}
\hline ÁREAS & DISCIPLINAS \\
\hline $\begin{array}{l}\text { 1)Fundamentos Teóricos da } \\
\text { Biblioteconomia/CI }\end{array}$ & $\begin{array}{l}\text { Inglês Instrumental } 1 \\
\text { Introdução à Biblioteconomia e à Ciência da Informação } \\
\text { Introdução à Comunicação } \\
\text { História Social e Política do Brasil } \\
\text { Biblioteca e Sociedade Brasileira } \\
\text { Evolução do Pensamento Filosófico e Científico } \\
\text { História dos Livros e das Bibliotecas }\end{array}$ \\
\hline $\begin{array}{l}\text { 2) Organização e Tratamento da } \\
\text { Informação }\end{array}$ & $\begin{array}{l}\text { Controle Bibliográfico } \\
\text { Editoração } \\
\text { Catalogação } \\
\text { Análise da Informação } \\
\text { Classificação } \\
\text { Indexação } \\
\text { Linguagens Documentárias }\end{array}$ \\
\hline
\end{tabular}

Continua

\footnotetext{
${ }^{31}$ Como a UNB ainda não reformulou seu currículo separamos as áreas curriculares de acordo as áreas da ABECIN e realizamos o cálculo do número de disciplinas em cada área e as porcentagens que eram destinadas a cada área para fazermos a comparação.
} 


\begin{tabular}{|l|l|}
\hline \multicolumn{1}{|c|}{ ÁREAS } & \multicolumn{1}{|c|}{ DISCIPLINAS } \\
\hline $\begin{array}{l}\text { 3) Recursos e Serviços de } \\
\text { Informação }\end{array}$ & $\begin{array}{l}\text { Bibliografia } \\
\text { Serviços de Informação }\end{array}$ \\
\hline 4) Tecnologias da Informação & $\begin{array}{l}\text { Introdução à Microinformática } \\
\text { Informática Documentária }\end{array}$ \\
\hline 5) Gestão da Informação & $\begin{array}{l}\text { Estatística Aplicada } \\
\text { Introdução à Administração } \\
\text { Planejamento de Sistemas de Informação } \\
\text { Planejamento e Elaboração de Bases de Dados } \\
\text { Gerência de Sistemas de Informação } \\
\text { Formação e Desenvolvimento de Acervos } \\
\text { Redes de Informação e Transferência de Dados } \\
\text { Estudos de Usuários }\end{array}$ \\
\hline 6) Pesquisa & $\begin{array}{l}\text { Organização do Trabalho Intelectual } \\
\text { Estágio Supervisionado em Biblioteconomia I } \\
\text { Estágio Supervisionado em Biblioteconomia II } \\
\text { Monografia em Biblioteconomia e Ciência da } \\
\text { Informação }\end{array}$ \\
\hline
\end{tabular}

Fonte: Pesquisa do autor.

Podemos perceber a ênfase do currículo da UNB na área curricular de Gestão da Informação. As áreas de Fundamentos Teóricos da Biblioteconomia e da Ciência da Informação, Tecnologia da Informação e Pesquisa, juntas, totalizam um percentual de 45,15\%, em detrimento das áreas de Organização e Tratamento da Informação, Recursos e Serviços de Informação e Gestão da Informação, as quais, juntas, agrupam um total de $54,85 \%$, conforme podemos perceber no Quadro 9.

Quadro 9- Comparação das áreas curriculares ABECIN e UNB

\begin{tabular}{|c|c|}
\hline ABECIN & UNB \\
\hline $\begin{array}{l}\text { 1)Fundamentos teóricos da } \\
\text { Biblioteconomia/CI- } 14 \%\end{array}$ & $\begin{array}{l}\text { 1)Fundamentos teóricos da } \\
\text { Biblioteconomia/CI- } \\
22,60 \%\end{array}$ \\
\hline $\begin{array}{l}\text { 2)Organização e tratamento da } \\
\text { informação- } 20 \%\end{array}$ & $\begin{array}{l}\text { 2)Organização e tratamento } \\
\text { da informação- } 22,60 \%\end{array}$ \\
\hline $\begin{array}{lccc}\text { 3)Recursos } & \text { e } & \text { serviços } & \text { de } \\
\text { informação- } 20 \% & & \end{array}$ & $\begin{array}{l}\text { 3)Recursos e serviços de } \\
\text { informação- } 6,45 \%\end{array}$ \\
\hline $\begin{array}{l}\text { 4)Tecnologia da informação- } \\
16 \%\end{array}$ & $\begin{array}{l}\text { 4)Tecnologia } \\
\text { informação- } 6,45 \%\end{array}$ \\
\hline 5)Gestão da informação- $20 \%$ & $\begin{array}{l}\text { 5)Gestão da informação- } \\
25,80 \%\end{array}$ \\
\hline 6) Pesquisa- $10 \%$ & 6) Pesquisa- $16,10 \%$ \\
\hline
\end{tabular}

Fonte: Pesquisa in loco.

Podemos perceber que a ênfase curricular nas áreas de Organização e Tratamento da Informação, Recursos e Serviços de Informação e Gestão da Informação denota uma 
ênfase maior nos processos de mediação informacional mais voltada para os aspectos técnicos da Biblioteconomia e da Ciência da Informação. Os aspectos ligados às mediações culturais ficam mais marginalizados, pois mesmo se nos voltarmos para as disciplinas de Fundamentação Teórica da Biblioteconomia e da Ciência da Informação, iremos perceber que são poucas as disciplinas dedicadas para a compreensão de uma contextualização históricocultural dos processos informacionais. Este fator pode ser decorrente da emergência da Sociedade da Informação, a qual, conforme analisamos anteriormente, quando citamos a obra de Daniel Bell, que a educação na pós-modernidade, é muito mais voltada para o treinamento dos indivíduos em técnicas do que mesmo para a reflexão crítica dos sujeitos da educação.

A ênfase do currículo da UNB está na área de Gestão da Informação, e, apesar de anterior, segue a tendência apontada pela ABECIN e pela UFSC. No entanto, na educação contemporânea, como o mundo que se nos está posto não é mais demarcado pelas certezas, e isso vem ocorrendo também com a Biblioteconomia/Ciência da Informação em relação à organização e gestão de dispositivos informacionais, seria muito mais importante que se voltasse a educação/formação de bibliotecários para o entendimento do contexto sócioinformacional e tecnológico no qual ele está inserido do que mesmo para a organização e tratamento de informação, haja vista que as transformações dos dispositivos informacionais estão postos e os profissionais que tratam a informação, a cada dia, já buscam a sua atualização.

\subsection{Caminho analítico do currículo do Curso de Biblioteconomia da USP}

O curso de Biblioteconomia e Documentação da Escola de Comunicações e Artes da Universidade de São Paulo nasceu no mesmo período em que foi regulamentada a profissão de bibliotecário no Brasil. Em junho de 1966, o Decreto Estadual nº. 46.419, instituiu a fundação da Escola de Comunicações Culturais (ECC), que mais tarde passou a se chamar Escola de Comunicações e Artes (ECA), com o Decreto nº 52.326, de 16 de dezembro de 1969. Os primeiros cursos da unidade foram: Artes Dramáticas, Biblioteconomia, Documentação, Cinema, Jornalismo, Rádio e TV, e Relações Públicas.

No ano de 1968, os cursos de Biblioteconomia e Documentação foram unificados e a escola adotou o currículo mínimo, o qual vigorou até o ano de 1984, momento em que foi aprovado o segundo currículo mínimo, e o Departamento de Biblioteconomia e Documentação iniciou a implantação de um novo currículo para o curso. Com a promulgação da Lei de Diretrizes e Bases da Educação Nacional, no ano de 1996, o currículo mínimo 
deixou de existir e, no ano seguinte, o Departamento elaborou um novo currículo de acordo com as Diretrizes Curriculares Nacionais. O aperfeiçoamento do currículo sempre foi uma preocupação constante do Departamento e vem sendo reformulado várias vezes, buscando formar profissionais críticos e reflexivos.

O atual Projeto Pedagógico do Curso de Biblioteconomia e Documentação da USP foi criado em agosto de 2007 e afirma que o curso de Biblioteconomia da Universidade de São Paulo tem como missão principal formar profissionais capazes de atuar no campo da informação, numa perspectiva integrada, com visão crítica, e com habilidades suficientes para gerenciar unidades de informação das diferentes organizações, por meio da utilização de técnicas e instrumentos específicos da prática profissional. Em primeiro lugar, percebemos a busca de uma formação holística para a formação de bibliotecários por meio desta unidade de registro e este tipo de educação vem ao encontro das ideias de uma educação transdisciplinar, tal qual proposta por Freitas; Morin e Nicolescu (1994). Portanto, trata-se de uma perspectiva que não se pauta apenas na formação voltada para o mercado de trabalho, mas sim, na formação holística de seus alunos, tais quais os preceitos da formação transdisciplinar. Também fica visível que uma boa parcela da formação dá-se na Fundamentação Teórica da Biblioteconomia, da Documentação e da Ciência da Informação, todavia, pouco se fala na formação de gestores culturais, da formação de profissionais para lidar com a mediação de culturas, embora mediar informação também é mediar cultura, haja vista que toda informação é produzida num determinado contexto sociopolítico econômico e cultural.

O que é importante observar neste currículo é que, embora o seu Programa de Pós-Graduação em Ciência da Informação (PPGCI) tenha inserido em uma de suas linhas de pesquisa as questões relacionadas à mediação, muito pouco se encontra em seu PPP as questões referentes a este tema. Por outro lado, embora haja uma boa parcela de disciplinas voltadas para a Gestão da Informação, este currículo confere uma ênfase nas disciplinas da Fundamentação Teórica, o que pode ser decorrência do seu Programa de Pós-Graduação, o qual visa a formar pesquisadores da área da informação.

Os objetivos gerais do Curso de Biblioteconomia e Documentação da USP é formar cidadãos conscientes de seu papel na sociedade de forma a contribuir para que, mediante o acesso à informação, as organizações prestem contas a seus públicos de sua responsabilidade social. É a primeira vez que um currículo, dentre aqueles que estamos analisando, fala da responsabilidade social diretamente e a referida diretriz é complementada por aquela que afirma ser outro objetivo geral do curso conscientizar os futuros profissionais 
de sua responsabilidade para com a sociedade, enquanto egressos de uma universidade pública. Portanto, o currículo cumpre aquilo que Rasse (2000) afirma ser a mediação, ou seja, técnicas, saberes-fazer.

Na contemporaneidade, as empresas passam a cada vez mais a ter a necessidade de prestar contas de suas ações para com a sociedade e, portanto, essas informações precisam ser tratadas de forma a que sejam divulgadas para a sociedade. Nesse sentido, a práxis do bibliotecário passa a ser realizada em três níveis: no nível estratégico realiza o mapeamento nos diversos setores da organização, coletando dados consistentes para conhecer as características da informação orgânica existente; ou seja, esta é a etapa do diagnóstico do ambiente de mediação de informação, o que pode ser feito com base no organograma da instituição. É nesta etapa que se conhece a estrutura da organização por meio de seus documentos e conhecem-se cada produtor documental tendo em vistas uniformizar a produção de documentos em meio analógico e/ou digital. No nível tácito elaboram-se documentos em meio eletrônico/digital, criando cópias e automatizando a vida útil do documento, contribuindo, desta forma, para tornar os fluxos de informação mais ágeis e seguros. No nível operacional executa tarefas cujo enfoque é voltado ao controle e manutenção dos programas de responsabilidade social, da aplicação de normas e especificações, utilização de manuais de procedimentos, cumprimento de cronogramas, etc ${ }^{32}$., conforme as formulações de Valentim (2010).

Os elementos analisados a partir dos níveis praxiológicos da formação do bibliotecário estão em consonância com outro objetivo do Curso de Biblioteconomia e Documentação da USP, qual seja: formar profissionais com visão estratégica de negócios numa sociedade globalizada e complexa e formar gestores dos processos de informação nas organizações, mediante a incorporação de conhecimentos teóricos e práticos na área. Estes dois últimos objetivos gerais estão ligados à área de Gestão da Informação, fato este que pode ser decorrência tanto das indicativas da ABECIN, a qual dedica uma atenção especial à área de Gestão da Informação, elaborando um documento a parte para tratar desta área curricular, quanto até mesmo devido ao Programa de Pós-Graduação em Ciência da Informação da Escola em lide, pois este possui como uma das áreas de suas linhas de pesquisa a Gestão de Dispositivos de Informação. Por outro lado, o primeiro objetivo específico vem a amenizar alguma leitura mais "dura" acerca da diretriz anterior quando afirma que a formação

\footnotetext{
${ }^{32}$ Para maiores detalhes acerca das diferenças dos níveis organizacionais, os quais foram readaptados para nossas reflexões acerca do currículo do curso de Biblioteconomia, Cf. VALENTIM (2010) no seu livro Ambientes e Fluxos de informações.
} 
bibliotecária na USP visa a proporcionar aos futuros profissionais uma formação geral e humanística capaz de conscientizá-los de seu papel como cidadãos e profissionais na sociedade contemporânea. Interessante a visão da formação de cidadãos e de profissionais, pois são duas categorias distintas, porém interligadas, portanto, esta afirmação nos leva a pensar mais uma vez que a USP visa a formar não apenas os profissionais para atuar no mercado de trabalho, mas também, cidadãos e profissionais conscientes de seu papel na sociedade contemporânea.

Outra questão bastante interessante aparece no próximo objetivo específico, o qual afirma que busca formar o futuro profissional para as atividades que este exercerá em unidades de informação, empresas de consultorias ou atuando com informação nas organizações públicas, privadas e do terceiro setor. Em primeiro lugar, reiteramos nesta unidade de registro que unidade é uma palavra derivada do latim unitate e refere-se à qualidade do que é um ou único, a saber, é qualquer coisa fixa, a qual se toma na sua totalidade, ou no sentido de ser desprovido de partes ou de suas partes serem inseparáveis da totalidade e inseparáveis entre si. Para o filósofo egípcio Plotino, a unidade é sempre necessária: "separados do um, os seres já não existem mais". Por exemplo, a biblioteca, o arquivo, o museu não existiriam se não fosse uma biblioteca, um arquivo, um museu. A biblioteca, o arquivo e o museu são não apenas porque são uma biblioteca, um arquivo e um museu, ou seja, se perdessem a sua unidade a sua essência continua a mesma, portanto, ainda assim existiria a informação para ser mediada de alguma forma. Por isso, não utilizamos a expressão unidade de informação, pois se o uno se separar, ele não existe mais, no caso das bibliotecas, arquivos e museus, se o um se separar ainda continuaria a essência desses lugares de memória, pois a informação continuaria existindo.

Já a palavra ambiente é derivada do latim ambiente, com o sentido do que envolve os corpos por todos os lados, ou seja, é o conjunto das substâncias, circunstâncias, condições em que determinada coisa existe ou onde ocorre determinada ação. É um complexo onde ocorrem algumas relações entre o mundo natural e o ser vivo que influi no comportamento do ser vivo. Daí, preferirmos denominar os lugares da memória de ambientes de mediação de informação, pois eles existem dentro de um contexto social e configura-se e reconfigura-se a partir desses contextos e, portanto, a cultura, a economia, a política, são instâncias que interferem no ser desses espaços, ou seja, dos ambientes de mediação de informações.

Também é interessante quando o currículo afirma que o futuro profissional estará preparado para atuar com informações em organizações públicas, privadas e no terceiro setor, pois é uma nova forma de perceber a formação dos profissionais da informação/bibliotecários, 
principalmente, no que concerne ao terceiro setor. No entanto, é importante estar ciente de que, embora no terceiro setor uma das áreas em que o bibliotecário poderá atuar seja a Gestão Cultural, é mister frisar que esta ação não é apenas realizar festivais, construir bibliotecas, arquivos históricos ou museus. São estas ações também, mas, sobretudo, é decidir que tipo de instituição se quer fazer e para qual cultura se vai implementar projetos e ambientes de mediação informativo-culturais. Na realidade, a gestão cultural contribui para a criação e recriação das indústrias culturais tradicionais, para a emergência dos não-mercados, para a promoção do acesso à cultura e da apropriação simbólica. Portanto, é também perceber que a cultura e a economia não podem ser mais vistas e praticadas de forma dialética, mas sim, dialógica. Desta feita, à maneira das ideias de García Canclini (2007), devemos buscar realizar mediações culturais no sentido de pesquisar mecanismos que busquem restabelecer os laços entre o espaço aberto da economia e o mundo fechado e fragmentado das culturas e efetivando aquilo que Castells $(1999,2010)$ propunha, ou seja, contestando a globalização técnico-econômica a partir de uma multiplicidade de fatores, de acordo com as diferentes culturas, histórias e geografias.

Outro objetivo do Curso de Biblioteconomia e Documentação da USP é formar empreendedores na prestação de serviços de informação para atender às demandas sociais da sociedade brasileira e internacional. Nesta categoria, percebemos as influências da Sociedade da Informação em sua elaboração, haja vista que, conforme Bell (1977), numa sociedade baseada em serviços, é necessário o investimento em educação a fim de se ingressar na sociedade pós-industrial, a qual sai da economia da produção de bens para uma economia baseada nos serviços. Por outro lado, percebemos uma formação não tão centrada no mercado de trabalho no currículo da USP quando este afirma que o curso de Biblioteconomia visa a possibilitar ao aluno, por meio da produção do TCC (Trabalho de Conclusão de Curso)Ciência da Informação, dando assim a oportunidade para que o formando se posicione intelectualmente frente a um tema escolhido para monografia final. Portanto, podemos afirmar que o modelo formativo da USP, provavelmente, devido ao seu programa de pósgraduação, em nível de mestrado e doutorado, busca uma formação também voltada para o âmbito da pesquisa, tanto no ambiente laboral, quanto no ambiente acadêmico e não se trata de mais um trabalho que é demandado para os alunos como forma de avaliação final e com o objetivo da nota.

Seguindo as diretrizes do MEC, e utilizando a linguagem do mesmo, o currículo do Curso de Biblioteconomia da USP fala das habilidades e competências da formação do bibliotecário, quais sejam: 1) Profissionais: racionalidade, visão estratégica, capacidade 
administrativa, dom de articulação política, e elevado grau de comunicabilidade. Nesta unidade de registro percebemos que são competências e habilidades que visam à formação de profissionais voltadas para o gerenciamento de informações em empresas e não para a mediação e a ação cultural, as quais também são áreas de formação de bibliotecários. Portanto, no campo educacional, vemos prevalecer, contemporaneamente, uma maior preocupação de voltar a formação e a própria linguagem educacional para os termos utilizados no mercado de trabalho e no mundo da economia financeira. No entanto, apoiamo-nos nas ideias de Sousa Santos (1989) quando este afirma que, no campo educacional, deve-se superar a contradição entre a linguagem técnica e a popular, e que este campo passe a utilizar uma gama de conceitos recriados e ampliados de tal forma que comporte todas as configurações linguísticas intermédias. É nesse sentido que afirmamos que não devemos transplantar para o mundo educacional as linguagens do mundo mercadológico, pois descaracterizaria a essência da educação. Por outro lado, é importante refletir sobre quais seriam os objetivos da educação, ou seja, a formação para a liberdade (no sentido sartriano do termo) do indivíduo, ou para o treinamento para o mercado de trabalho?

Dentre as habilidades profissionais, a fim de alcançar as supracitadas o profissional da informação/bibliotecário, deve possuir: a) cultura geral e humanística; b) domínio das técnicas e instrumentos da Biblioteconomia; c) conhecimentos especializados de administração, Arquivologia e Linguística aplicada à Documentação; d) visão estratégica de negócios; e) capacidade administrativa e articulação política; e) domínio da língua portuguesa; f) conhecimento de idioma estrangeiro. Estas habilidades e competências estão, em sua maioria, voltadas para a formação de um bibliotecário gestor de ambientes de mediação da informação. Na realidade, estas habilidades e competências estão voltadas para os modelos formativos de uma Sociedade da Informação, tal qual preconizada por Bell (1977), Masuda (1982) e, no campo mais especificamente educacional, analisada criticamente por Marrach (2001) e Freire (2000). Portanto, percebemos a mescla de uma formação voltada para os aspectos humanísticos (tal como a da primeira Escola de Biblioteconomia, na Biblioteca Nacional, Rio de Janeiro), bem como para os aspectos mais técnicos da formação (como o da Escola Livre de Sociologia e Política, São Paulo), os dois primeiros modelos formativos de bibliotecários. Este fato parece a superação da dicotomia entre teoria e prática, o que faz os cursos de Biblioteconomia passarem a ser praxiológico na contemporaneidade. Embora, a formação esteja se encaminhando para isso, ainda se pode perceber nos currículos da Biblioteconomia que a prática ainda continua bastante acentuada (tanto por parte dos professores, quanto devido às interpelações dos alunos, os quais, quando chegam as 
disciplinas da área técnica, as suas maiores indagações é quando vão começar para a parte prática do curso).

Já as habilidades pessoais que o Curso de Biblioteconomia e Documentação da USP busca formar referem-se à criatividade, equilíbrio emocional, princípios éticos sólidos e capacidade de liderar, planejar e administrar. Conforme Tyler (1976) toda formulação de objetivos educacionais deve ser uma exposição das mudanças que devem operar-se nos alunos de forma a que as atividades de ensino possam ser planejadas e desenvolvidas de uma forma capaz de atingir esses objetivos, produzindo mudanças nos alunos. Portanto, as habilidades e competências na formação em Biblioteconomia da USP estão em consonância com os reais objetivos da educação, as quais foram postuladas por Tyler. No entanto, é a primeira vez, dentre os currículos analisados, que percebemos menção a características pessoais dos alunos a serem moldadas.

Outras habilidades pessoais são utilizar as metalinguagens pertinentes à sua atividade; desenvolver e aplicar instrumentos de trabalho adequados; processar a informação, quaisquer que sejam os suportes, linguagens, formatos e mídias em que se encontrem, de acordo com as teorias, paradigmas, métodos e técnicas da área e gerenciar unidades, serviços e sistemas de documentação e informação. Podemos inferir que são competências e habilidades voltadas para o que-fazer dos alunos nos ambientes de mediação de informação e que vislumbra uma maior área de atuação dos profissionais da informação/bibliotecários. Na realidade, também se refere a um perfil de profissional não apenas gestor dos ambientes de mediação da informação; mas, sobretudo, de um bibliotecário gestor nesses ambientes, principalmente, quando afirma que uma das habilidades pessoais é a utilização de linguagens e metalinguagens nos ambientes de mediação de informação. Portanto, é partir desse conteúdo que percebemos que o currículo da USP vislumbra a formação de um bibliotecário mediador, haja vista que, conforme Floris (1995) a língua é o primeiro fator privilegiado da mediação.

Dentre as habilidades que vislumbram a formação de bibliotecários, tanto mediador de informações e de culturas, quanto de pesquisador refere-se a demarcar campos específicos e integrar conteúdos de áreas correlatas em uma perspectiva multidisciplinar; produzir e divulgar conhecimentos; desenvolver ações pedagógicas voltadas tanto para a melhoria do desempenho profissional, como para a ampliação do conhecimento em geral. Uma questão bastante interessante neste conteúdo refere-se a que podemos vislumbrar três norteamentos para a formação do profissional na USP, conforme o seu PPP, ou seja, de um bibliotecário educador, de um bibliotecário mediador e de um bibliotecário, principalmente (e 
é aqui onde recai a ênfase desse currículo), gestor de ambientes de mediação de informação. Estes três eixos formativos da Biblioteconomia da USP são a formação de um bibliotecário gestor, mediador e educador. O próprio PPP desta escola afirma que a ECA é uma escola de vocação acadêmico-profissionalizante. As suas diversas estruturas curriculares apresentam dois tipos essenciais de formação (a crítico-acadêmica e a técnico-profissionalizante) que não são excludentes, mas que ora enfatizam o saber acadêmico, ora o saber-fazer profissional. Portanto, podemos afirmar que este currículo é praxiológico no sentido de que não visa a apenas treinar os alunos nos métodos e técnicas da Biblioteconomia e da Ciência da Informação, mas visa a que os alunos compreendam em qual contexto se encontra e se dá a utilização dessas técnicas.

Outra questão que persistimos em discutir nas análises dos currículos refere-se à perspectiva de um currículo multi, inter e pluri disciplinar, haja vista persistirmos na perspectiva da transdisciplinaridade. Por quê? Em primeiro lugar, porque a perspectiva multidisciplinar refere-se a várias matérias para estudar um determinado elemento sem se preocupar em interligar as disciplinas entre si, o que significa, ainda, a fragmentação do conhecimento, fator que deve, pari passu, ser superado na educação contemporânea. Em segundo lugar, porque a perspectiva da transdisciplinaridade está lado a lado com a perspectiva de uma sociedade que é baseada em redes de informação e de conhecimentos. Sim, pois a sociedade e, por conseguinte, o currículo em rede, está articulado de forma a superar a fragmentação social e do conhecimento, abrindo-se às trocas; não busca a hierarquização social, nem educacional, portanto, não hierarquiza o conhecimento e leva em conta as diversidades, sem, contudo, dispersá-las.

Outras habilidades e competências da formação do bibliotecário na universidade em lide referem-se a realizar atividades profissionais autônomas de modo a orientar, dirigir, assessorar, prestar consultorias, realizar perícias, emitir e assinar laudos técnicos e pareceres; responder às demandas sociais determinadas pelas transformações tecnológicas que caracterizam o mundo contemporâneo e refletir criticamente sobre sua prática profissional. Estas unidades de registro estão em consonância com as diretrizes do MEC para a formação de bibliotecários e, portanto, conforme já dissemos anteriormente, estão ligadas, em parte, à visão da pedagogia das competências, ou seja, não de uma educação em seu sentido pleno, a qual se propõe como libertadora do indivíduo e que busca a transformação deste e do próprio mundo; pelo contrário, a grande questão da pedagogia das competências é que ela vislumbra a formação de indivíduos socialmente competentes e esta forma de ver a educação está diretamente ligada aos preceitos de uma educação neoliberal. Ou seja, buscar 
preparar os alunos para a competitividade mercadológica e laboral, e sua abordagem pedagógica está vinculada às demandas atuais do processo produtivo capitalista, que está cada vez mais flexível. Por outro lado, esse mesmo conjunto de unidade de registro busca que o leitor desvie o olhar para interpretações mais críticas acerca das mesmas, quando afirma que busca responder às demandas sociais e a que o aluno reflita, criticamente, sobre a sua realidade. Portanto, são diretrizes antagônicas que atuam no currículo no sentido de esconder o real sentido do conjunto dos conteúdos.

Ainda no âmbito da atuação profissional e do mercado de trabalho, encontramos que o alvo do currículo de Biblioteconomia e Documentação da USP refere-se a que o mercado de trabalho alvo é: a) assessorias de serviços de informação; b) atuação de forma autônoma; c) consultorias a empresas e terceiro setor; d) empresas comerciais, prestadoras de serviços, e) indústrias em geral; f) sindicatos; $g$ ) associações patronais $e$ de trabalhadores; h) escolas; i) agências de propagandas; j) hospitais e clínicas médicas; l) empresas de turismo, rádio, televisão; m) bibliotecas. Portanto, percebemos que este currículo (assim como os três outros anteriores, como o da UFPA, UFSC e UNB) está em consonância com as transformações do mercado laboral dos bibliotecários frente às demandas formativas da Sociedade da Informação. Portanto, o perfil geral do aluno formado na USP é ser um gestor de informação nas organizações, característica que podemos inferir ser oriunda tanto das ênfases na área curricular de Gestão da Informação nas indicativas da ABECIN, quanto devido à linha de pesquisa em Gestão dos Dispositivos de Informação do PPGCI da USP. Já em relação à formação do bibliotecário voltar-se para a atuação de forma autônoma esta é mais uma das características em sintonia com as perspectivas da Sociedade da Informação, haja vista que os seus ideólogos, a exemplo de Bell (1977) e Masuda (1982), afirmaram que o trabalho na Sociedade da Informação seria concretizado de quaisquer locais e bastaria ter um computador e conhecimentos pessoais.

Os objetivos específicos da educação bibliotecária da USP são: 1) conceber, implementar e administrar serviços de informação vinculados a instituições da esfera pública e privada; 2) elaborar diagnósticos, prognósticos, estratégias e políticas voltadas para o tratamento técnico, busca, recuperação e disseminação da informação em seus diversos formatos, mídias e suportes; 3) atuar junto a organizações públicas elou privadas que incluam atividades caracterizadas por estratégias que visem à organização, recuperação e disseminação da informação, adequando-se às necessidades das comunidades que atendem.

As três diretrizes supracitadas, em conjunto, vislumbram a formação de um bibliotecário gestor e mediador de informação, sim; principalmente, porque as atividades de 
organização da informação são, antes de tudo, atividades que visam à mediação de informações para os usuários. Ou seja, as atividades de organização de materiais de mediação de informação, conforme afirma Almeida Júnior (2009) são ações de interferências, as quais são realizadas pelos profissionais da informação tendo em vistas a apropriação de informações por parte dos leitores. Por outro lado, não percebemos preocupação nesse e nos currículos dos Cursos de Biblioteconomia até aqui analisados em relação às ações de desintermediação da informação, ou seja, aquelas atividades, que, conforme Lèvy (2000), não existe mais a figura do mediador da informação e o filtro passa a ser realizado pelo próprio usuário.

Também percebemos a sempre constante preocupação do currículo da USP em formar bibliotecários que são, antes de tudo, pesquisadores, haja vista que ele é o profissional que guia os outros pesquisadores pelas entrelinhas das informações e dos materiais de mediação de informação. É nesse sentido que o currículo passa a se preocupar em formar profissionais aptos a: 1) participar de equipes multidisciplinares voltadas para a elaboração de políticas de informação de caráter institucional, Estadual, Regional ou Federal, bem como pelo desenho de macrocenários que tenham a informação como objetos de estudos. Nesta unidade de registro percebemos que vislumbra as políticas de informações culturais, também, pois visa à formação de um bibliotecário que esteja voltado para a formação de equipes multidisciplinares. Noutro sentido, seria importante se definir como seria a forma de abordagem dos trabalhos em relação à disciplinaridade de cada ator do processo das formulações das políticas de mediação informativo-cultural, pois os conhecimentos deveriam ser contemplados na perspectiva da transdisciplinaridade, pois é a forma de abordagem disciplinar que mais se encaixa nas características da mediação da informação, pois tanto a língua, quanto o espaço social, quanto as instituições, são instâncias mediadoras.

Embora o currículo afirme que o profissional estará apto a trabalhar em equipes multidisciplinares, em outra unidade de registro encontramos que ele também estará apto a 2) realizar a interlocução entre as funções típicas da área de informação e as demais funções profissionais ou empresariais da área da Comunicação e, ainda, com outras áreas sociais, culturais e econômicas com as quais os profissionais da informação exerçam interface. Portanto, esta unidade de registro aponta para a perspectiva da transdisciplinaridade, pois é nesse sentido que afirmamos que a informação em si não existe, mas apenas na sua forma mediada; ou seja, a informação é um processo e não um fenômeno em si, haja vista que ela, para existir, precisa de um sujeito que transforme os dados recebidos em significações, em informações e, para isso, são necessárias várias mediações de tempo, espaço, e recursos 
mnemônicos os quais auxiliarão o homem a traduzir os dados em informações. É nesse sentido que afirmamos não haver a informação em si, mas sim, as informações já nascem mediadas, além de percebermos que a diretriz também remete ao paradigma da transdisciplinaridade, haja vista que a própria mediação já atua na perspectiva transdisciplinar, pois realiza o religare de todas as disciplinas entre si, rompendo as fronteiras disciplinares, mas ainda assim, continuando disciplinar, dialeticamente. Daí, o próprio radical da palavra não ter desaparecido, haja vista que as ciências são disciplinares, mesmo que as tomemos no nosso fazer e pensar as ciências de forma transdisciplinar.

O currículo do Curso de Biblioteconomia e Documentação da USP também visa a 3) estimular a formação de futuros docentes e investigadores nos domínios da informação, educação e comunicação, que constituem áreas de atuação naturais para o profissional da informação. Portanto, visa à formação de bibliotecários não apenas técnico dos recursos informacionais e que saiba guiar os leitores diante da avalanche informacional digital contemporânea, mas, sobretudo, um profissional que seja ele mesmo um pesquisador em sua práxis. Por outro lado, temos a unidade de registro que afirma que a formação da USP possibilita ao profissional 4) exercer todas as demais atividades que, no estado então vigente da profissão, sejam reconhecidas, pelo bom senso, pelas entidades representativas ou pela legislação pertinente, como características do profissional de informação.

Fica-nos, portanto, a seguinte questão: quais são as características do profissional e do mercado de trabalho do profissional da informação/bibliotecário quando os acervos estão constituídos em forma de fluxos na rede? Esta unidade de registro parece muito mais uma espécie de direcionamento de reserva de marcado para os profissionais da informação, todavia, como realizar reserva de mercado, num momento em que o mercado e a própria sociedade se encontra na sua forma líquida, para utilizar expressões de Bauman?

Podemos perceber pela disposição das disciplinas nas áreas curriculares, as quais foram estabelecidas pela ABECIN, que não há explicitamente no currículo da USP uma disciplina visivelmente voltada para a mediação informativo-cultural. Pelo contrário, podemos perceber que esta área da mediação é contemplada devido a algumas disciplinas, cujos conteúdos implicitamente estão voltados para a mediação, tais como Serviço ao Usuário, Orientação à Pesquisa Bibliográfica e Estudos de Usuários, os quais estão voltados para a mediação, embora não aborde conceitualmente a mediação enquanto insumo de trabalho para o profissional da informação/bibliotecário.

Outra questão a se colocar é em relação à área de Tecnologias da Informação, haja vista que somente uma disciplina está voltada explicitamente para essa área, embora saibamos 
que os conhecimentos acerca das Tecnologias de Informação e de Comunicação podem estar inseridos no currículo de maneira transversal, o que, na realidade, está explícito nas Diretrizes Curriculares Nacionais para os Cursos de Biblioteconomia brasileiros.

A partir dos dados acima extraídos do currículo do Curso de Biblioteconomia e Documentação da USP, realizamos a análise comparativa das áreas curriculares do curso em questão em relação às áreas da ABECIN, conforme podemos visualizar abaixo (QUADRO 10):

Quadro 10- Comparação das áreas curriculares ABECIN e USP

\begin{tabular}{|ll|l|}
\hline \multicolumn{2}{|c|}{ ABECIN } & \multicolumn{1}{|c|}{ USP } \\
\hline $\begin{array}{l}\text { 1)Fundamentos teóricos da } \\
\text { Biblioteconomia/CI- 14\% }\end{array}$ & $\begin{array}{l}\text { 1) Fundamentos teóricos da } \\
\text { Biblioteconomia/CI 35,20\% }\end{array}$ \\
\hline $\begin{array}{l}\text { 2)Organização e tratamento da } \\
\text { informação- 20\% }\end{array}$ & $\begin{array}{l}\text { 2)Organização e tratamento da } \\
\text { informação 20,60\% }\end{array}$ \\
\hline $\begin{array}{l}\text { 3)Recursos e serviços de informação- } \\
\text { 20\% }\end{array}$ & $\begin{array}{l}\text { 3)Recursos e serviços de } \\
\text { informação 14,70\% }\end{array}$ \\
\hline 4)Tecnologia da informação- 16\% & $\begin{array}{l}\text { 4)Tecnologia da informação } \\
\text { 3\% }\end{array}$ \\
\hline 5)Gestão da informação- 20\% & $\begin{array}{l}\text { 5)Gestão da informação } \\
\text { 14,70\% }\end{array}$ \\
\hline 6) Pesquisa- 10\% & 6) Pesquisa- 11,80\% \\
\hline
\end{tabular}

Fonte: Pesquisa in loco.

Diante da análise do Quadro 10 podemos inferir que o currículo do Curso de Biblioteconomia e Documentação da USP possui sua ênfase na área curricular de Fundamentos Teóricos da Biblioteconomia e da Ciência da Informação (35,20\%). Outra ênfase deste currículo refere-se à área de Organização e Tratamento da Informação (20,60\%). Por outro lado, se juntarmos as áreas de Recursos e Serviços de Informação com a de Gestão da Informação, haja vista as duas áreas serem uma, complemento da outra, então as duas somariam $(29,40 \%)$ e seria outra ênfase curricular. Este fato pode ser decorrente dos investimentos das pesquisas do Programa de Pós-Graduação em Ciência da Informação desta universidade, embora não seja um fator determinante. E por que não? Em primeiro lugar, porque se fizermos a análise comparativa com os outros cursos em análise que possuem pósgraduação na área, a exemplo da UFSC e da UNB, podemos perceber que a ênfase destes dois currículos encontra-se na Gestão da Informação, sendo que recebem 29,41\% (UFSC) e $25,80 \%$ (UNB), respectivamente, do total das disciplinas. Já o currículo da USP, a área que recebe maior número de disciplinas é a de Fundamentos Teóricos da Biblioteconomia e da Ciência da Informação. 
Percebemos que a distribuição das disciplinas previstas por esse currículo está elaborada de forma não uniforme, pois a maioria das disciplinas é dividida em duas partes, o que as fragmenta e impossibilita a inserção de novos conhecimentos disciplinares no interior do fluxo curricular. Também percebemos que os conhecimentos que estão inseridos em duas ou três disciplinas, poderiam estar articulados em uma única, a exemplo do currículo da UFSC, o qual possui disciplinas intituladas Tópicos Especiais, as quais são subdivididas para as áreas de Fundamentos Teóricos da Biblioteconomia e da Ciência da Informação; Recursos e Serviços de Informação; Organização e Tratamento da Informação; Gestão da Informação e Tecnologias da Informação. Na realidade, este currículo também está elaborado de maneira não-uniforme até mesmo devido à distribuição disciplinar no fluxo curricular, o qual, ora contém seis disciplinas por semestre, ora contém quatro disciplinas, além de que um semestre possui apenas duas disciplinas como é o caso do oitavo semestre.

\subsection{Caminho analítico do currículo do Curso de Biblioteconomia da UFC}

O Curso de Biblioteconomia da Universidade Federal do Ceará teve sua aprovação no Conselho Universitário (CONSUNI) por meio da Resolução n ${ }^{\circ} 153$ de 17 de fevereiro de 1964 e teve seu funcionamento autorizado, pela Resolução n 174 , de 22 de janeiro de 1965. Foi reconhecido pelo MEC por meio do Decreto $\mathrm{n}^{\circ} 70.168$ de 18 de fevereiro de 1972 e foi publicado no Diário Oficial da União em 21 de fevereiro de 1972. Na época, a forte influência do primeiro reitor da UFC, Prof. Antônio Martins Filho, auxiliado pela bibliotecária Lydia Queiroz Sambaquy que, à época, era casada com o então ministro Júlio Furquim Sambaquy e que, por ocasião do $3^{\circ}$ Congresso Brasileiro de Biblioteconomia e Documentação, realizado em Fortaleza, conseguiu concretizar seu intento. Também sempre lembrada é a Bibliotecária Maria da Conceição Souza, a qual propiciou a qualificação dos primeiros bibliotecários da universidade para trabalhar nas bibliotecas da $\mathrm{UFC}^{33}$. Foram estes profissionais que, posteriormente, assumiram o cargo de docência, fundando o Curso de Biblioteconomia na Instituição.

Atualmente, o Curso de Biblioteconomia encontra-se no Departamento de Ciências da Informação (DCI), cuja criação deu-se em 17 de agosto de 2000, em reunião de Departamento; em 21 de setembro de 2000, a aprovação da criação do Departamento foi efetivada em reunião no Conselho do Centro de Humanidades e, no dia 14 de maio de 2001,

\footnotetext{
${ }^{33}$ Para maiores detalhes acerca da História do Curso de Biblioteconomia da UFC, Cf. CYSNE, F. P. Biblioteconomia: dimensão social e educativa. Fortaleza: EUFC, 1993.
} 
foi aprovada a criação do DCI no CONSUNI (trinta e sete anos após a aprovação da criação do curso no CONSUNI). O atual PPP foi elaborado em 2004. Este curso tem duração de quatro anos, com 3072 horas/aula e duração de quatro anos (oito semestres) e está vinculado ao Centro de Humanidades, área 2, da UFC.

Já no início de seu Projeto Político Pedagógico este currículo atua numa postura mais aberta ao paradigma da informação não-materializada e do documento, percebendo a atuação do bibliotecário em quaisquer espaços que possuam informação que precisa ser tratada para fins de tratamento, mediação, acesso, uso, descarte e/ou reuso. Portanto, o documento afirma que o profissional formado pela UFC atua no gerenciamento da informação em setores públicos e privados, em espaços industriais, postos de informação, além de bibliotecas, arquivos e museus, no ensino e na pesquisa em Biblioteconomia e na Ciência da Informação. Nesse sentido, o curso amplia a sua visão acerca do profissional da informação/bibliotecário, mas também hibridiza a sua formação, haja vista que, quando as bibliotecas, os arquivos e os museus passam a atuar em ambiente ciberespacial não tem mais como realizarmos delimitações firmes e seguras acerca de quem seria o "detentor" de tal domínio do conhecimento, muito menos das áreas de atuação profissional.

Outra questão importante a salientar em relação ao currículo do Curso de Biblioteconomia da UFC é que, embora não possua uma pós-graduação na área de Ciência da Informação, ele é bastante aberto ao paradigma da informação, bem como à visão de um bibliotecário mediador, educador e pesquisador, produtor ele mesmo de conhecimentos e não mais apenas um servum servore scientiae. Para que esse profissional seja um sujeito ativo na construção do conhecimento e de mediador dos consulentes e educandos nos seus projetos de conhecimentos, independentemente do nível, é necessário compreender as diferentes concepções filosóficas sobre o conhecimento; entender e interagir no ambiente sociopolítico e econômico que está inserido. Nesse sentido, esse currículo aposta em disciplinas como Introdução à Filosofia, Introdução à Sociologia, Teoria e Prática da Leitura, Cultura e Mídia, Informação e Sociedade, Introdução à Pesquisa Documentária, Metodologia do Trabalho Científico, Métodos Quantitativos em Biblioteconomia e Ciência da Informação, Metodologia da Pesquisa em Biblioteconomia e Ciência da Informação e Monografia I, Monografia II e Monografia III as bases teóricas para o fazer mais profundo do bibliotecário enquanto mediador e, ele mesmo, pesquisador. Portanto, do total de 43 disciplinas, 12 estão relacionadas ao entendimento da sociedade e da cultura (5), perfazendo $21,42 \%$ da formação, bem como ao fazer científico (7), que contabiliza 19,05\%, o que totaliza 40,47\% do conjunto das disciplinas. Todavia, se a estas disciplinas juntarmos aquelas que estão relacionadas às 
tecnologias $(11,37 \%)$, as quais, em sua maioria, propõem uma reflexão acerca das mesmas e não apenas ao ensino das tecnologias de uma forma tecnicista, então essa porcentagem se eleva para $52,37 \%$, o que se torna maioria das disciplinas.

Uma questão que a maioria dos currículos de Biblioteconomia aqui estudados ainda trata de forma enfática é do conceito de Disseminação da Informação, conforme podemos perceber na unidade de registro utilizar técnicas de coleta, tratamento, recuperação $e$ disseminação da informação. No entanto, conforme já afirmamos anteriormente, a disseminação não tem a ver com apropriação, ou seja, com o sujeito tomar para si determinados conhecimentos e ser impulsionado para a ação, conforme a etimologia da palavra nos assedia. Pelo contrário, a palavra disseminação pela etimologia (disseminare e actio) da palavra refere-se ao ato de semear, espalhar, irradiar (sêmen), ou seja, seria espalhar a informação, mas sem a preocupação com a apropriação dessas informações por parte do sujeito. Nesse sentido, preferimos a utilização do conceito de mediação da informação, tal qual proposto por Almeida Júnior (2009), ou seja, como uma ação de interferência do profissional da informação que favorece a apropriação de informações.

Uma unidade de registro que nos leva a perceber que este currículo que tem uma visão de um bibliotecário-mediador refere-se a que o profissional da informação/bibliotecário deve buscar integrar-se a diferentes grupos profissionais, desenvolver habilidades do profissional autônomo e desenvolver e executar atividades culturais, dentre elas, programas de leitura. Portanto, o currículo prevê a formação de um profissional da informação/bibliotecário transdisciplinar, ou seja, um bibliotecário que saiba dialogar com os diferentes tipos de usuários da informação, que elabore materiais de mediação de informação e linguagens documentárias pensando nos mais diversos perfis profissionais para os quais irá realizar o tratamento informativo-documentário e que se utilize de outras áreas de conhecimentos com as quais mantém relações interdisciplinares para realizar o seu que-fazer tendo em vistas a uma atuação verdadeiramente transdisciplinar.

Nesse sentido, o perfil ideal delineado pelo curso de Biblioteconomia da UFC refere-se a um profissional com capacidade para o desenvolvimento gerencial, com habilidades de pesquisa e habilidades pedagógicas, de liderança proativa, domínio em determinada área, compreendendo o valor da informação a nível governamental $e$ reconhecimento da importância pública, política, social, econômica e cultural da informação. Podemos perceber que a educação proposta para o bibliotecário é aquela que Freire (1959) denomina de dialógica, ou seja, aquela em que o professor em vez de transmitir os conteúdos da educação, realiza o diálogo entre os conteúdos e a realidade dos educandos. Portanto, seria 
uma educação que estaria baseada em observações diretas, fazendo com que a teoria e a prática estejam em constante diálogo praxiológico, aquilo que o próprio Marx denominou de educação multilateral, a saber, aquela em que não se valoriza somente o lado intelectual, nem somente o manual, o prático, mas a síntese entre as duas formas. Também percebemos por meio desta unidade de registro que a informação por ela tratada não se refere apenas a uma informação que já está lapidada, mas sim, aquelas que são dados a ser tratados de forma a fazer sentido para os sujeitos, ou seja, que se tornem informações e/ou documentos para a tomada de decisões por parte dos sujeitos. Além disso, possibilita a formação de bibliotecários gestores de ambientes de mediação de informação, investigador em seus processos de trabalhos e educador de informações, ou seja, um bibliotecário que ensine aos alunos a usar os materiais de mediação de informação.

Devido a esse perfil profissional delineado pelo currículo da UFC a sua visão acerca do campo de atuação do bibliotecário também é ampliado e afirma que esse campo é aquele constituído de bibliotecas, empresas públicas e privadas, ONGs, universidades, escolas de ensino fundamental e médio, empresas jornalísticas, radiofônicas e televisivas, hospitais públicos e privados, indústria, comércio, setores de entretenimento, bibliotecas virtuais de bancos, agências de turismo, departamentos governamentais, ou qualquer outro setor que requeira a gestão da informação para tomada de decisão, crescimento e competitividade. Portanto, a própria visão do que seria informação nesse currículo é ampliada, à medida que não fica restrito apenas aos espaços tradicionais de atuação do bibliotecário e busca, em sua formação, que as áreas atuantes na informação, como a Arquivologia e a Museologia estejam contempladas em seu currículo, uma vez que, do ponto de vista epistemológico não há razões para tal separação, como o fez a ciência moderna com essas disciplinas. Nesse sentido, percebemos que, realmente, o currículo está baseado numa epistemologia transdisciplinar, ou seja, ele apreende ao mesmo tempo a unidade e a diversidade, não percebendo a Biblioteconomia como uma entidade fechada, pelo contrário, ela dá conta da pluralidade das Ciências da Informação, dialogando com a Arquivologia e a Museologia, porém, ainda, de uma forma bastante incipiente. É como se a Biblioteconomia estivesse pari passu deixando de se tornar uma entidade fechada ao dialogar e inserir em seus currículos os conhecimentos das áreas coirmãs, mas, ao mesmo tempo, respeitando a identidade de cada uma delas.

A unidade de registro supra-analisada é complementada com a que afirma que $o$ Curso abre espaço para o aperfeiçoamento e aprofundamento de propostas didáticopedagógicas capazes de responder às diversas demandas da formação de profissionais das 
ciências da informação, bem como, responder às constantes demandas da inserção da universidade pública em diversas instâncias da sociedade. Por esta via, seria interessante que as três formações estivessem unidas em torno de uma única ciência, mas respeitando-se as identidades de cada uma delas, promovendo a unidade na diversidade.

Dentre os objetivos da formação do bibliotecário nesta escola estão: geralproporcionar aos egressos do Curso de Biblioteconomia um ensino de qualidade tornando-os indivíduos reflexivos, dando ênfase à formação e desenvolvimento profissional, visando um domínio e competência humana, tecnológica, política e social, que lhe permita atuar no mercado e na sociedade, garantindo o desenvolvimento humano e compreendendo os paradoxos da humanidade. Nesse sentido, o curso em lide visa a que os sujeitos da educação não apenas tenham uma formação para o técnico, para o fazer; mas, sobretudo, para a reflexão de sua atuação profissional enquanto agente transformador da realidade. Portanto, fala de competência humana, tecnológica (que é um objeto técnico que incorporou ciência), política (ou seja, é uma das poucas vezes na história da Biblioteconomia em que um currículo fale da dimensão política da formação e da atuação do bibliotecário ${ }^{34}$ ) e, sobretudo, social.

Já os objetivos específicos são: a) proporcionar a participação político-social levando em consideração os direitos e deveres do cidadão, a fim de que possa exercer dignamente a sua cidadania; b) desenvolver a formação do indivíduo habilitando ao exercício da profissão com competência humana e tecnológica, tendo em vista uma atuação transformadora do seu fazer pragmático; c) propiciar culturalmente os profissionais para um melhor entendimento dos paradoxos da sociedade em que vivem, visando uma maior atuação profissional; d) promover o desenvolvimento integral do indivíduo, com vistas a uma atuação humanística; e) provocar capacidade reflexiva para o trabalho em equipe. Todos estes objetivos para a formação do bibliotecário estão relacionados com a responsabilidade social desse profissional no tocante à mediação da informação para a sociedade. Em primeiro lugar, está relacionado à mediação uma vez que, conforme podemos perceber dos objetivos acima, o profissional irá buscar assegurar a dimensão individual do sujeito quando afirma que irá desenvolver a integralidade do sujeito; em segundo lugar, também busca assegurar a dimensão coletiva da sociabilidade quando afirma que visa a proporcionar a participação político-social. Portanto, nestes objetivos, está assegurada a mediação tal qual conceituada por Lamizet e Silem (1967).

\footnotetext{
${ }^{34}$ Acerca da temática da dimensão política na formação e na atuação de bibliotecários cf. SOUZA, F. C. O ensino de Biblioteconomia no contexto brasileiro (1990).
} 
O curso possui laboratórios, considerados importantes equipamentos para viabilizar a execução das atividades curriculares. Os espaços didáticos permitem implementar as dimensões da- Pesquisa, Documentação e Informação- proporcionando aos alunos um local de investigação permanente sobre métodos, experiências e material didático, voltado aos sistemas de comunicação em seus diversos níveis. Outros espaços serão incorporados visando reconhecer e incentivar a criatividade dos alunos estruturados em parceria com o Museu de Arte (MAUC), Rádio Universitária (FM), Casa Amarela Exílio Oliveira, Imprensa Universitária e Instituto de Cultura e Arte (ICA). Laboratórios: 1) Laboratório de Tecnologias de Informação e Comunicação; 2) Biblioteca Laboratório Prof. Antônio Martins Filho; 3) Residência Informacional nas Bibliotecas Setoriais do Sistema de Bibliotecas Universitárias da UFC; 4) Sala de Leitura; 5) Laboratório de Informática do Centro de Humanidades.

Interessante observar que a forma de visualizar a biblioteca universitária por parte desse currículo vai além da forma como os outros o percebem, haja vista que ela é percebida como um verdadeiro laboratório no ambiente de ensino-aprendizagem dos alunos. Portanto, utilizando-se a BU como laboratório, ela não atuará nos currículos dos cursos apenas como um ambiente no qual os alunos têm a possibilidade de, no final do curso, realizar seu estágio curricular; mas sim, que todas as disciplinas utilizar-se-ão da biblioteca como um apoio pedagógico em suas disciplinas, tanto pelos materiais e serviços de informação que ela dispõe, quanto pela possibilidade de, desde a entrada dos alunos no curso, ele já estar familiarizado com a ambiência da biblioteca. Também é interessante observar que, mesmo sem o Curso de Biblioteconomia da UFC possuir uma Pós-Graduação na área da Ciência da Informação, ele tem uma visão muito maior das potencialidades curriculares da Biblioteca Universitária em seu texto curricular, o que não encontramos nos currículos de Biblioteconomia, aqui analisados, cujos cursos possuem a Pós-Graduação.

O projeto foi articulado por uma concepção de educação fundamentada na perspectiva transdisciplinar, cuja abordagem remete para o aprender a aprender, aprender a fazer, aprender a viver em conjunto e aprender a ser. Isto implica em uma interação comunicacional entre professores, texto e contexto da formação profissional, revocando diálogo entre os professores e alunos com vistas à revisão constante de planos de ensino, de programas e de conteúdos, à renovação dos referenciais metodológicos norteadores da gestão do processo ensino-aprendizagem e respeito ao compromisso do Curso, reafirmando uma formação profissional. Esta forma de compreender a educação implica o estabelecimento de interações comunicacionais entre professores, texto e contexto da formação profissional, 
ensejando a manutenção de diálogos entre professores e alunos, tendo em vista revisões constantes nos planos de ensino, nos programas e conteúdos. Sem esquecer, também a renovação dos referenciais metodológicos norteadores da gestão do processo ensinoaprendizagem, numa demonstração efetiva de respeito ao compromisso do curso no que concerne à formação profissional.

A avaliação do rendimento escolar na UFC é feita por disciplina e, quando se faz necessário, na perspectiva de todo o curso, abrangendo sempre a assiduidade e a eficiência, ambas eliminatórias por si mesmas. Em relação à avaliação, pode-se perguntar quais os cuidados- se existem- para que esta não seja realizada como a avaliação do neoliberalismo, a qual é uma avaliação que tem por principal meta a competitividade entre as escolas e entre os alunos e quem for mais "capacitado" terá melhores chances de inserção no mercado de trabalho.

Outra questão a se analisar em relação ao processo avaliatório da Biblioteconomia da UFC refere-se a que a verificação da eficiência em cada disciplina é realizada progressivamente durante o período letivo e, ao final deste, de forma individual ou coletiva, utilizando formas e instrumentos de avaliação indicados no plano de ensino e aprovados pelo Departamento. Em relação à eficiência nos processos de ensino e aprendizagem e no mundo do trabalho Freire (1979) já havia afirmado que a palavra eficiência teve, ao longo dos tempos, seu significado alterado, deixando de ser a capacidade de pensar e de criar, para se tornar o cumprimento preciso e pontual. A fim de ultrapassar essa visão de educação pautada na eficiência, a qual Marrach (2001) afirmara ser uma das características da educação neoliberal, o educador brasileiro propõe que a educação desenvolva a consciência crítica, que liberte o homem, em lugar de submetê-lo, de adaptá-lo. Nesse sentido, não é à toa que, no momento em que o neoliberalismo adentra o cenário político, econômico, social, cultural e educacional brasileiro, as escolas e universidades passam pelo surto avaliatório de sua eficiência nos processos de ensino e aprendizagem. Neste momento, passaremos para a análise das áreas curriculares e das disciplinas da UFC (Quadro 11) a fim de perceber a ênfase que se está dando no currículo do curso de Biblioteconomia da UFC.

Um breve olhar sobre a distribuição disciplinar nas áreas curriculares no quadro abaixo (Quadro 11), podemos perceber que tem um maior número de disciplinas da área curricular de Pesquisa e de Tecnologias da Informação, o que nos leva a entender a ênfase desse currículo na área tecnológica e investigativa. Nesse sentido, é um avanço em relação ao currículo anterior, ao qual também tivemos acesso e que estava bem mais baseado na área de organização da informação e de forma ainda bem tradicional. Outra questão desse currículo 
refere-se a que a área curricular de estágio aumentou bastante, pois, se no currículo anterior o estágio, geralmente, encontrava-se no final do curso, atualmente, ele se encontra, no atual currículo, a partir do sexto semestre. Se por um lado, significa um avanço no sentido de que abre maiores possibilidades de atuação profissional e de variedades de lugares de ensinoaprendizagem no mercado de trabalho; por outro lado, pode vir a despertar a fissura pela atuação no mercado por si só e cada vez mais a formação ser baseada nos anseios do mercado de trabalho, o qual, como sabemos, é fluido e, constantemente, faz aparecer e desaparecer alguns mercados, profissões e cursos.

Quadro 11- Comparação das áreas curriculares ABECIN e UFC

ABECIN UFC

\begin{tabular}{|l|l|}
\hline $\begin{array}{l}\text { 1)Fundamentos Teóricos da Biblioteconomia } \\
\text { e da Ciência da Informação- } 14 \%\end{array}$ & $\begin{array}{l}\text { 1) Fundamentos Teóricos da Biblioteconomia } \\
\text { e da Ciência da Informação- } 21,42 \%\end{array}$ \\
\hline $\begin{array}{l}\text { 2)Organização e Tratamento da Informação- } \\
20 \%\end{array}$ & 2) Processamento da Informação- $21,42 \%$ \\
\hline 3)Recursos e Serviços de Informação- 20\% & 3) Recursos e Serviços de Informação- 9,53\% \\
\hline 4)Tecnologia da Informação- 16\% & 4) Tecnologia da Informação- $11,90 \%$ \\
\hline 5)Gestão da Informação- 20\% & 5) Gestão de Unidades de Informação- 9,53\% \\
\hline 6) Pesquisa- 10\% & 6) Pesquisa- $19,05 \%$ \\
\hline & 7) Estágio- $7,15 \%$ \\
\hline
\end{tabular}

Fonte: Pesquisa documental.

Em relação ao curso de Biblioteconomia da UFC podemos perceber que a ênfase da UFC é nas áreas curriculares de Fundamentos Teóricos da Biblioteconomia e da Ciência da Informação $(21,42 \%)$ e na de Processamento da Informação $(21,42 \%)$. Por outro lado, se considerarmos Pesquisa (19,05\%) e Estágio (7,15\%) como integrantes da área de Fundamentação Teórica da Biblioteconomia e da Ciência da Informação, então teremos a ênfase nessa área curricular, com 37,62\% das disciplinas, o que seria uma maior carga horária em Fundamentos. Além disso, diminui a carga horária para a área de Recursos e Serviços de Informação destinando apenas 9,53\% das disciplinas do currículo, ou seja, 10,47\% a menos do que sugere a ABECIN.

Se tomarmos a ABECIN como modelo ideal para o currículo do Curso de Biblioteconomia da UFC percebemos que ele optou por não seguir a nomenclatura nem as porcentagens da ABECIN (que datam de 2001 a 2005), mesmo tendo sido elaborado depois do lançamento destes documentos.

\subsection{Algumas considerações sobre os currículos numa perspectiva comparativa}


Se a existência precede a essência, o homem não pode ser classificado por nenhum conceito cabal e fechado, ou pautar-se por qualquer valor definitivo, visto que, assim como a existência, os valores também são construções da realidade humana.

(Sartre).

A partir do pensamento de Sartre, afirmamos que as análises até aqui realizadas não refletem uma realidade que é fechada, acabada, até mesmo porque os homens são seres inacabados, por isso, estão em busca permanente. Este fato, Paulo Freire chamava de vocação do ser-mais. Puxando um diálogo com Hannah Arendt, a mesma afirma que, porque os homens nascem para o mundo, a educação tem que ser conservadora como forma de inserir os que estão chegando num mundo que é velho. Nesse sentido, acreditamos que o diálogo entre Paulo Freire e Hannah Arendt apresenta uma complementaridade, ambos sendo autores que nortearam as análises sobre os currículos de formação de bibliotecários que realizamos. Juntamente com eles, as análises sobre a formação de bibliotecários a partir dos documentos que visam a nortear a sua formação, foram pautadas pelos autores mais críticos acerca da sociedade contemporânea. Portanto, foi dessa maneira que buscamos analisar a amostragem dos PPPs das cinco regiões brasileiras.

Em relação aos documentos da ABECIN, os quais serviram como uma espécie de modelo ideal para as análises dos PPPs, foi possível perceber que, muitas vezes, as suas indicativas não foram seguidas, principalmente, em relação à quantidade de disciplinas que seriam destinadas a cada área curricular (Quadro 11). Por outro lado, essas porcentagens não são indicativas somente da ABECIN, mas foi um consenso entre os diretores das Escolas de Biblioteconomia do MERCOSUL, tanto o estabelecimento das áreas curriculares, quanto a porcentagem de disciplinas de cada área curricular.

As indicativas da ABECIN embora acenem para as questões relativas à mediação, ainda assim apresentam uma grande ênfase nos processos de Gestão da Informação e de Organização da Informação (Quadro 12), fato este que veio a influenciar alguns currículos. 
Quadro 12- Comparação das áreas curriculares da ABECIN, UFPA, UFSC, UNB, USP e UFC

\begin{tabular}{|c|c|c|c|c|c|}
\hline ABECIN & UFPA & UFSC & UNB & USP & UFC \\
\hline $\begin{array}{ll}\text { 1)Fundamentos } & \\
\text { Teóricos } & \text { da } \\
\text { Biblioteconomia e } & \text { da } \\
\text { Ciência } & \text { da } \\
\text { Informação- 14\% } & \end{array}$ & $\begin{array}{l}\text { 1)Fundamentação } \\
\text { Teórica da } \\
\text { Biblioteconomia- } \\
11 \%\end{array}$ & $\begin{array}{l}\text { 1)Disciplinas } \\
\text { Instrumentais- } \\
20,58 \%\end{array}$ & $\begin{array}{l}\text { 1)Fundamentos } \\
\text { Teóricos da } \\
\text { Biblioteconomia e da } \\
\text { Ciência da } \\
\text { Informação- 22,60\% }\end{array}$ & $\begin{array}{l}\text { 1) Fundamentos } \\
\text { Teóricos da } \\
\text { Biblioteconomia e da } \\
\text { Ciência da Informação } \\
-35,20 \%\end{array}$ & $\begin{array}{l}\text { 1) Fundamentos } \\
\text { Teóricos da } \\
\text { Biblioteconomia e da } \\
\text { Ciência da } \\
\text { Informação- } 21,42 \%\end{array}$ \\
\hline $\begin{array}{lr}\text { 2)Organização } & \mathrm{e} \\
\text { Tratamento } & \mathrm{da} \\
\text { Informação- 20\% } & \end{array}$ & $\begin{array}{l}\text { 2)Organização da } \\
\text { Informação- } 23 \%\end{array}$ & $\begin{array}{l}\text { 2) Fundamentos de } \\
\text { Biblioteconomia e de } \\
\text { Ciência da } \\
\text { Informação- } 11,77 \%\end{array}$ & $\begin{array}{l}\text { 2)Organização e } \\
\text { Tratamento da } \\
\text { Informação- 22,60\% }\end{array}$ & $\begin{array}{l}\text { 2)Organização e } \\
\text { Tratamento } \\
\text { Informação- } 20,60 \%\end{array}$ & $\begin{array}{l}\text { 2) Processamento da } \\
\text { Informação- } 21,42 \%\end{array}$ \\
\hline $\begin{array}{l}\text { 3)Recursos e Serviços } \\
\text { de Informação- } 20 \%\end{array}$ & $\begin{array}{l}\text { 3)Recursos } \\
\text { Serviços- } 23 \%\end{array}$ & $\begin{array}{l}\text { 3) Organização e } \\
\text { Tratamento da } \\
\text { Informação- } 17,65 \%\end{array}$ & $\begin{array}{l}\text { 3)Recursos e Serviços } \\
\text { de Informação- } 6,45 \%\end{array}$ & $\begin{array}{l}\text { 3)Recursos e Serviços } \\
\text { de Informação- } \\
14,70 \%\end{array}$ & $\begin{array}{l}\text { 3) Recursos e Serviços } \\
\text { de Informação- } 9,53 \%\end{array}$ \\
\hline $\begin{array}{l}\text { 4)Tecnologia } \\
\text { Informação- } 16 \%\end{array}$ & & $\begin{array}{l}\text { 4) Recursos e } \\
\text { Serviços de } \\
\text { Informação- } 11,76 \%\end{array}$ & $\begin{array}{ll}\text { 4)Tecnologia } & \mathrm{da} \\
\text { Informação-6,45\% }\end{array}$ & $\begin{array}{l}\text { 4)Tecnologia } \\
\text { Informação- } 3 \%\end{array}$ & $\begin{array}{l}\text { 4) Tecnologia da } \\
\text { Informação- } 11,90 \%\end{array}$ \\
\hline $\begin{array}{ll}\text { 5)Gestão } & \text { da } \\
\text { Informação- 20\% }\end{array}$ & $\begin{array}{lr}\text { 4)Gestão } & \text { de } \\
\text { Unidades } & \mathrm{e} \\
\text { Serviços- } 23 \% & \end{array}$ & $\begin{array}{l}\text { 5) Gestão } \quad \text { da } \\
\text { Informação- } 29,41 \%\end{array}$ & $\begin{array}{l}\text { 5)Gestão da } \\
\text { Informação- 25,80\% }\end{array}$ & $\begin{array}{l}\text { 5)Gestão da } \\
\text { Informação- 14,70\% }\end{array}$ & $\begin{array}{l}\text { 5) Gestão de Unidades } \\
\text { de Informação- 9,53\% }\end{array}$ \\
\hline 6) Pesquisa- $10 \%$ & $\begin{array}{l}\text { 5) Cultura e } \\
\text { Formação Geral- } \\
20 \%\end{array}$ & $\begin{array}{l}\text { 6) } \\
5,88 \%\end{array}$ & 6) Pesquisa- $16,10 \%$ & 6) Pesquisa- $11,80 \%$ & 6) Pesquisa- $19,05 \%$ \\
\hline & & 7) Estágio- 2,95\% & & & 7) Estágio- 7,15\% \\
\hline
\end{tabular}

Fonte: Pesquisa empírica. 
Em relação à área de Fundamentos Teóricos da Biblioteconomia e da Ciência da Informação, a ABECIN propõe que sejam destinadas $14 \%$ das disciplinas do currículo. A UFPA diminui essa porcentagem para $11 \%$ e a UFSC para 11,77\%; todavia, a UFPA não possui pós-graduação em Ciência da Informação, mas a UFSC a possui. Por outro lado, se considerarmos a área de Disciplinas Instrumentais, tal qual consta no currículo da UFSC, como pertencente à área de Fundamentos, então essa área passaria a ter 32,35\% das disciplinas do currículo, mais do que propõe a ABECIN. A UNB concentra, também, um grande número de disciplinas na área de Fundamentação e a USP é a universidade que mais concentra disciplinas nessa área curricular (ambas possuem PPGCI). Todavia, esse fator de haver a pós-graduação em CI não foi determinante para que essa área curricular obtivesse o um maior número de disciplinas, haja vista que a UFC possui um grande número de disciplinas na primeira área curricular e não possui PPGCI. Além desse fator, concorre outro, que é em relação a que os currículos não seguiram a quantidade e a nomenclatura das áreas curriculares da ABECIN (as quais foram estabelecidas em reuniões no âmbito do MERCOSUL) e esse fato merece menção, uma vez que ela é a associação que rege o ensino e a pesquisa em Ciências da Informação no País. Todavia, podemos perceber que, quando da elaboração das indicativas da ABECIN para as Escolas das áreas das Ciências da Informação (Biblioteconomia, Arquivologia e Museologia) os membros-participantes foram, em sua maioria, professores e pesquisadores ligados às Escolas de Biblioteconomia.

À área de Organização e Tratamento da Informação a ABECIN propõe $20 \%$ do número de disciplinas, já a UFPA aumenta em 3\% a quantidade de disciplinas desse currículo. A UFSC diminui essa área curricular em 35\%, talvez para aumentar a área de Fundamentos Teóricos da Biblioteconomia e da Ciência da Informação. A UNB dedica 22,60\% das disciplinas, a USP 20,60\% e a UFC 21,42\%. Essas porcentagens podem indicar as ênfases de cada currículo nas áreas curriculares, ou seja, percebemos que a UNB e a USP possuem suas ênfases na área de Gestão da Informação e de Organização da Informação. Em relação à UFC o que se pode afirmar é que ela possui ênfase nas áreas curriculares de Fundamentos da Biblioteconomia e na de Organização e Tratamento da Informação. Portanto, apresenta um equilíbrio em seus aspectos mais humanistas e nos mais técnicos, o que gera uma ambivalência positiva em sua formação, até importante nos tempos atuais, pois não se prende nem aos aspectos totalmente práticos, muito menos nos aspectos totalmente humanistas, mas propicia uma simbiose entre os dois modelos formativos. 
Recursos e Serviços de Informação é a terceira área curricular da ABECIN e, para a Associação, o ideal seria disponibilizar 20\% do total das disciplinas do currículo para essa área curricular. Todavia, a UFPA aumenta para $23 \%$ o número total das disciplinas desse currículo e é o que mais possui disciplinas nessa área curricular no País, dentre os currículos que estamos analisando. O currículo que possui menos disciplinas nessa área é o da UNB, o qual destina apenas $6,45 \%$ do total de disciplinas, sendo, portanto, $13,55 \%$ a menos do que as indicativas da ABECIN sugerem. Outro currículo que possui, também, um menor número de disciplinas na área de Recursos e Serviços de Informação é o da UFC, o qual destina apenas 9,53\% das disciplinas do currículo, ou seja, 10,47\% a menos do que sugere a ABECIN. Já a USP e a UFSC possuem nesta área curricular $14,70 \%$ e $11,76 \%$ do total de disciplinas do currículo nesta área curricular, respectivamente.

A quarta área curricular da ABECIN denomina-se Tecnologia da Informação e, conforme as indicativas da associação, a ela devem ser destinadas $20 \%$ do total das disciplinas do currículo. Por um lado, soa bastante interessante haja vista que não se pode mais ficar alheio às possibilidades trazidas com as Tecnologias de Informação, bem como aquelas que agregam para si o predicativo "de comunicação" também. Por outro, as diretrizes do MEC já preveem que os conhecimentos de Tecnologias da Informação e da Comunicação, bem como os de Pesquisa poderiam ficar "diluídos" em todas as outras disciplinas do currículo. Nesse sentido, a UFPA não possui essa área em seu currículo, todavia, esse curso afirma em seu currículo que busca empregar as tecnologias para otimizar o trabalho de organização, recuperação e mediação da informação nos ambientes de mediação de informações. As disciplinas mais práticas do currículo como as de Indexação, Classificação e Catalogação ainda são mediadas em formato tradicional apenas, deixando de lado as formas mais contemporâneas de catalogação em linha. Há também uma dicotomização entre teoria e prática no currículo da UFPA, tendo disciplinas que se intitulam de Prática em algumas áreas curriculares, fazendo-nos perceber que a teoria é dada numa determinada disciplina e a prática em outra. Na UFSC há duas disciplinas no currículo que atentam para as questões das tecnologias, mas muito mais como saber-fazer, quais sejam: Gestão de Documentos e Informatização de Unidades de Informação. Na UNB existem apenas quatro disciplinas que atentam para a área de TICs, quais sejam: Introdução a Microinformática; Planejamento e Elaboração de Bases de Dados; Redes de Informação e Transferência de Dados; Informática Documentária. Na USP a única disciplina dessa área curricular denomina-se Documentação e Informática. A UFC destina 11,90\% das disciplinas de seu currículo para essa área curricular. 
A área de Gestão da Informação é uma das que tem mais disciplinas demandadas pela ABECIN, que, juntamente com a de Organização e Tratamento da Informação, devem ter $20 \%$, respectivamente, das disciplinas do currículo destinadas. Todavia, com exceção dos currículos da USP e da UFC, todos os outros currículos aumentaram a quantidade de disciplinas dessa área curricular. A UFPA aumentou em 3\%, a UNB em 5,80\% e a UFSC em 9,41\%. Portanto, a maioria dos currículos analisados possui sua ênfase na área de Gestão da Informação.

Pesquisa é outra área curricular delineada pela ABECIN e presente em quase todos os currículos analisados, exceto no da UFPA. No currículo da UFSC essa área curricular denomina-se Monografia e são destinadas a ela 5,88\% das disciplinas do currículo, ou seja, 4,12\% a menos do que é sugerido pela ABECIN, o que é de se estranhar haja vista eles possuírem PPGCI, além de terem alterado o nome da área curricular para Monografia. A UNB aumentou a área em 6,10\%, ou seja, ela dedica 16,10\% das disciplinas de seu currículo para a área curricular de Pesquisa, o que vai ao encontro da nossa hipótese inicial de que os cursos que possuem PPGCI teriam uma maior pendência curricular, na graduação, para a área de Pesquisa. Todavia, temos de atentar que o currículo da UNB ainda não fez alterações substanciais desde a demanda do MEC em 2001. A USP é outra universidade cujo curso de Biblioteconomia não fez alterações substanciais em seu currículo, mas também aumentou um pouco o número de disciplinas da área curricular de Pesquisa, ou seja, 1,80\% a mais do que o que sugere a ABECIN. Já a UFC possui 19,05\% na área curricular de Pesquisa, 9,05\% a mais do que propõe a ABECIN e mais, até mesmo, do que os cursos que possuem pós-graduação na área de Ciência da Informação.

Há ainda os currículos que não seguem as indicativas da ABECIN no que diz respeito ao número e às nomenclaturas das áreas curriculares. A UFPA aumentou as áreas curriculares inserindo a de Cultura e Formação Geral, dedicando a ela $20 \%$ das disciplinas do currículo. A UFSC (que possui a área de Estágio a mais, dedica-lhe 2,95\% das disciplinas) e a UFC, a qual também possui suplementarmente a área curricular de Estágio, possui 7,15\% das disciplinas nessa área curricular. Portanto, a partir desses dados percebemos a diversidade dos caminhos seguidos pelos currículos de formação do bibliotecário brasileiro.

Em relação às áreas curriculares da ABECIN, a universidade que mais se aproximaria desse "modelo ideal" é a UFPA, e a que menos se aproxima é a UFC, por conta da quantidade de disciplinas destinadas a cada área curricular.

Em relação a cada universidade e aos seus arranjos no que concerne à mediação percebemos que a primeira universidade analisada, a UFPA, pauta seus currículos no que 
concerne à mediação, tanto a mediação técnica, quanto à mediação social, incluindo, inclusive, duas disciplinas no currículo que tratam diretamente dos processos de mediação. Esse currículo trata da formação de bibliotecários mediadores, mas ainda dicotomizando teoria e prática, o que nos faz perceber que mesmo que esse currículo trate da mediação de forma explícita, ainda no corpo de seu PPP o assunto permanece tratado de forma elementar, enfatizando, sobretudo, a formação de um bibliotecário gestor dos ambientes de mediação da informação.

O currículo da UFPA trata da mediação de forma explícita, tanto de uma mediação mais tradicional, quanto mais contemporânea (midiatização), fazendo uma simbiose entre os dois tipos de mediação; mas, mesmo assim, pouco trata da formação de bibliotecários mediadores. Trata de uma mediação mais cultural e aponta para a constituição de um currículo que contemple a transculturalidade (aquilo que está através e além das culturas). Por outro lado, o currículo ainda possui uma dimensão técnica e não privilegia, por exemplo, os aspectos mais teóricos de historicidade e epistemologia da Biblioteconomia, Documentação e Ciência da Informação.

O currículo da UFSC, pelo seu PPP, percebemos que busca formar um bibliotecário mediador e pesquisador. Tem um aspecto inovador que são as disciplinas de Tópicos Especiais, as quais visam a atender aos anseios da sociedade contemporânea, sem abrir mãos dos conhecimentos mais tradicionais dos currículos de Biblioteconomia. Por outro lado, dá pouca atenção aos aspectos da mediação, enfatizando a formação nos aspectos da Gestão da Informação.

O currículo da UNB privilegia a iniciação científica e possui sua ênfase na Gestão da Informação, visando a adaptação do seu currículo aos anseios do mercado de trabalho, tomando este como principal mediação no interior do currículo. Por outro lado, possui uma boa porcentagem de disciplinas na área de Fundamentos Teóricos da Biblioteconomia e da Ciência da Informação.

O currículo da USP baseia-se na transdisciplinaridade, mas pouco fala das questões mediacionais, embora o PPGCI possua uma linha de pesquisa de Mediação da Informação. Uma questão interessante deste currículo é que é a sociedade, e não o mercado, a principal mediação dentro do currículo.

O currículo da UFC é aberto ao paradigma da informação, como os anteriores, e da perspectiva transdisciplinar, mas ainda de forma incipiente. Possui ênfase na área curricular de Fundamentos Teóricos da Biblioteconomia e da Ciência da Informação e na de Processamento da Informação, pouco tratando das questões mediacionais em si. 
Em relação a todos esses currículos analisados existem alguns arranjos promissores para a formação de profissionais da informação e, o primeiro deles, refere-se a que essa formação já se encontra hibridizada com os arquivistas e museólogos no interior dos currículos. Todavia, é preciso atentar que não é possível formar um profissional híbrido pleno apenas com disciplinas de introdução às outras duas áreas de conhecimentos e atuação profissional.

Um arranjo que nos parece promissor para o encaminhamento dos currículos poderia ser o da UFC, porém retirando-se a grande quantidade de disciplinas que este currículo possui sobre a Gestão de Ambientes de Mediação da Informação e de Estágio e inserindo mais disciplinas como a exemplo da UFPA sobre a mediação da informação em si. Além disso, seria interessante, como forma de responder aos anseios da sociedade contemporânea, inserir nesses currículos as disciplinas de Tópicos Especiais em cada uma das cinco áreas curriculares da $\mathrm{ABECIN}$, como forma de preservar a tradição e não ficar inserindo várias disciplinas no interior dos currículos. 


\title{
5 REFLEXÕES FINAIS: DIALÉTICAS CURRICULARES
}

\begin{abstract}
Exatamente em benefício do que é novo e revolucionário em cada criança é que a educação precisa ser conservadora; ela deve preservar essa novidade e introduzi-la como algo novo em um mundo velho, que, por mais revolucionário que possa ser em suas ações, é sempre, do ponto de vista da geração seguinte, obsoleto e rente à destruição. [...]. É sobremodo difícil para o educador arcar com esse aspecto da crise moderna, pois é de seu ofício servir de mediador entre o velho e o novo, de tal modo que sua própria profissão the exige um respeito extraordinário pelo passado. [...]. Sem tradição - que selecione e nomeie, que transmita e preserve, que indique onde se encontram os tesouros e qual o seu valor - parece não haver nenhuma continuidade consciente no tempo, e portanto, humanamente falando, nem passado nem futuro, mas tão-somente a sempiterna mudança do mundo e o ciclo biológico das criaturas que nele vivem.
\end{abstract}

Hannah Arendt (1954).

Inicialmente, gostaríamos de afirmar que a realização desta pesquisa não encontrou caminhos tranquilos desde a sua gênese; primeiro, porque estudar os currículos de formação de quaisquer áreas de conhecimentos e de quaisquer níveis de ensino não se constitui tarefas das mais fáceis, principalmente, devido ao fato de que a abertura desses documentos, por parte das universidades, significa mostrar os seus pontos fortes, mas, sobretudo, suas fragilidades. Ou seja, o estudo do currículo é também o estudo do ser ou não ser dos cursos, de suas identidades.

De posse do material empírico e por meio das análises que realizamos nos cinco currículos dos cursos de Biblioteconomia no Brasil, podemos perceber que os mesmos estão se guiando, muitas vezes, na dialética do ser ou não ser (liquidez identitária), para usar expressão shakesperiana, e esse fato não é novo no campo da Biblioteconomia. Todavia, com o advento da denominada "Ciência da Informação", mais uma vez os cursos, que antes tinham uma identidade definida, e que vinham atuando desde os tempos mais remotos com a mediação da informação, tais como Biblioteconomia, Arquivologia e Museologia, passam por um momento de redefinição de suas identidades a partir do momento em que os ambientes de mediação de informação passam a "existir" em um não-lugar, também denominado de ciberespaço.

Durante todo o trabalho mobilizamos os mais diversos autores a fim de compreendermos as várias conceituações do que seria denominado por contemporaneidade (a qual é a delimitação temporal desta pesquisa) e os dois principais conceitos encontrados foram: modernidade e pós-modernidade, todavia, sem nenhum consenso entre os autores das delimitações conceituais entre os dois termos. Esse primeiro momento não foi uma tarefa fácil, pois há muita divergência entre os autores, não somente em relação às questões 
terminológicas, mas, sobretudo, conceitual e temporal. Por isso, buscamos analisar os mais diversos autores que eram convergentes e, também, os que divergiam entre si, a fim de delinearmos alguns parâmetros para nossas reflexões acerca das análises de conteúdo.

Essas questões também vieram a desaguar na Biblioteconomia, pois, como forma de não desaparecer no mundo acadêmico-científico, teve de passar a atentar para as TICs em seu fazer. Num primeiro momento, os conhecimentos sobre as tecnologias foram inseridas muito timidamente nos currículos, todavia, contemporaneamente (pós anos 2000) esses conhecimentos foram inseridos de forma bastante efetiva nos conteúdos e nas práticas de ensino, tomando, muitas vezes, as tecnologias como "mecanismos de modernidade e de salvação". Ou a Biblioteconomia se apropriaria das TICs, ou ela estaria destinada ao desaparecimento, ao descrédito ou ao fracasso, o que não deixaria de ser um modo de inexistência.

Desta feita, além de todas essas confusões terminológicas e conceituais da sociedade, também encontramos várias outras desse gênero em relação à conceituação de informação, profissional da informação, Biblioteconomia, Ciência da Informação e não apenas em relação à conceituação, mas, também, em relação à historicidade desses campos de conhecimentos. Percebemos que profissional da informação é qualquer profissional que tenha como insumo de trabalho a informação; ou seja, qualquer profissional é um profissional da informação em sua área. Foi nesse sentido que ao utilizarmos essa terminologia de profissional da informação, sempre utilizamo-nos da barra especificadora, ou seja, profissional da informação/bibliotecário e assim por diante.

Se tomarmos a sociedade contemporânea como Sociedade da Informação, podemos perceber que ela alterou a formatação dos currículos dos cursos de Biblioteconomia brasileiros no sentido de que as Tecnologias de Informação e de Comunicação estão perpassando todo o conteúdo dos Projetos Político-Pedagógicos analisados, além da forma como se trata a questão da mediação no interior dos currículos.

Em relação à mediação da informação, pouco se tem tratado da temática nos PPPs, mesmo levando-se em consideração que é um fazer que perpassa todas as atividades dos bibliotecários. A mediação em si, aliada às TICs, tornando-se midiatização, é um espaço privilegiado para ampliação das possibilidades de aprofundamento da capacidade de reflexão dos alunos no interior de sua formação, uma vez que elas ampliam o espaço de participação dos sujeitos cognoscentes, os quais, por meio da sua formação, podem ressignificar seu papel de sujeitos do processo educativo e da sua participação na sociedade. Apesar dessas possibilidades propiciadas pelas TICs, ainda assim, é importante que o bibliotecário não perca 
o fio da tradição de sua formação (e de suas disciplinas mais tradicionais), uma vez que nem todos os lugares em que esse profissional vai atuar possuem essas tecnologias mais sofisticadas e até mesmo como forma de preservar a tradição da área e a identidade do curso e do profissional, mesmo levando-se em consideração que, na atual conjuntura socioeconômica e cultural é impossível se pensar a partir do uno, do disciplinar, da identidade, sem a pluralização dessas terminologias.

A sociedade contemporânea, ou da informação, vem afetando a Educação como um todo, principalmente, em relação ao seu papel social, inserindo um paradoxo nessa área. Ou seja, a educação tem por papel inserir o indivíduo num mundo que já está posto para ele (tradição), e também de atualizá-lo, de fazer com que este homem permaneça como um sujeito do mundo (modernidade). A grande questão que se coloca para a Educação na Sociedade da Informação é fazer dialogar no interior da formação o fio da tradição com o da modernidade, não dicotomizando as duas formas educacionais. Só assim acreditamos ser possível uma apropriação crítica do que é novo e emergente.

Nesse sentido, que relembramos o papel da ABECIN nas discussões que, historicamente, vem fazendo acerca da formação de bibliotecários, todavia, no sentido de tentar fazer dialogar também as áreas afins, quais sejam, a Museologia e a Arquivologia, como forma de se repensar a formação dos profissionais da informação na contemporaneidade, não no sentido da disciplinaridade como já fora feito, mas no sentido de se repensar uma educação transdisciplinar iniciando-se pelo restabelecimento do diálogo entre as três áreas, como forma de se pensar as Ciências da Informação e não somente a Ciência da Informação entendida apenas como Biblioteconomia. 


\section{REFERÊNCIAS}

ASSOCIAÇÃO BRASILEIRA DE EDUCAÇÃO EM CIÊNCIA DA INFORMAÇÃO. Projeto Pedagógico e Avaliação da Graduação: referências para a renovação e ressignificação do ensino em Biblioteconomia/Ciência da Informação. In: Oficina de Trabalho de São Paulo, 2001, São Paulo. Disponível em: <http://www.abecin.org.br/portal/abecin/main.php?sl =docabe>. Acesso em: 15 fev. 2009.

Avaliação da graduação em Biblioteconomia e Ciência da Informação: bases conceituais, metodológicas e princípios do processo avaliativo. In: Oficina Regional de Trabalho Sudeste/Centro-Oeste, 2002, Vitória. Disponível em:

<http://www.abecin.org.br/portal/abecin/main.php?sl=docabe>. Acesso em: 15 fev. 2009.

Avaliação do processo formativo na área de Biblioteconomia/Ciência da Informação: documento referencial. In: Oficina Regional de Trabalho Norte/Nordeste; VI Seminário Nacional de Avaliação Curricular, 2002, Fortaleza. Disponível em:

<http://www.abecin.org.br/portal/abecin/main.php?sl=docabe>. Acesso em: 15 fev. 2009.

Diretrizes para a construção de indicadores de qualidade para a avaliação de cursos de graduação de Biblioteconomia e Ciência da Informação. In: Oficina Regional de Trabalho Sul/São Paulo, 2002, Florianópolis. Disponível em: <http://www.abecin.org.br/portal/abecin/main.php?sl=docabe>. Acesso em: 15 fev. 2009.

AKRICH, Madeleine. Technique et médiation. Réseau, v. 11, n. 60, p. 87-98, 1993.

Disponível: <http://www.persee.fr/revues/home/prescript/article/reso_0751-7871_1993_num_ 11_60_2368>. Acesso: 30 ago 2010.

ALMEIDA, Marco Antônio de. A gaiola de chips: apontamentos sobre tecnologia, sociabilidade e cultura na Sociedade da Informação. Em Questão, Porto Alegre, v. 11, n. 1, p. 13-34, jan./jun. 2005.

- Mediações da cultura e da informação: perspectivas sociais, políticas e epistemológicas. Tendências da Pesquisa Brasileira em Ciência da Informação, [s.1.], v. 1, n. $1,2008$.

Mediação cultural e da informação: considerações socioculturais e políticas em torno de um conceito. 2007. In: ENCONTRO NACIONAL DE PESQUISA EM CIÊNCIA DA INFORMAÇÃO, 8., 2007, Salvador. Anais eletrônicos... Disponível em: <http://www.enancib.ppgci.ufba.br/artigos/GT3--212.pdf>. Acesso em: 15 abr. 2010.

Literatura, informação, conhecimento e ciência. In: (Org.) Ciência da Informação e Literatura. Campinas: Editora Alínea, 2012. cap. 4, p. 91-118.

ALMEIDA, Marco Antônio de; CRIPPA, Giulia. Informação, Cultura e Tecnologia: novas mediações para a produção e o consumo cultural. 2009. In: ENCONTRO NACIONAL DE PESQUISA EM CIÊNCIA DA INFORMAÇÃO, 10., 2009, João Pessoa. Anais

Eletrônicos... Disponível em:

<http://dci2.ccsa.ufpb.br:8080/jspui/bitstream/123456789/500/1/GT\%203\%20Txt\%206\%20A LMEIDA,\%20Marco\%20Ant\%C3\%B4nio_\%20 CRIPPA,\%20Giulia\%20\%20Informacao.pdf>. Acesso em: 20 maio 2011. 
ALMEIDA, Paulo Roberto de. O Brasil e a nanotecnologia: rumo à quarta revolução industrial. Revista Espaço Acadêmico, Maringá, v. 5, ano 5, n. 54, set. 2005.

ALMEIDA JÚNIOR, Oswaldo Francisco de. Mediação da informação e múltiplas linguagens. Pesq. Bras. Ci. Inf., Brasília, v. 2, n. 1, p. 89-103, jan./dez. 2009.

ALTHUSSER, Louis. Ideologia e aparelhos ideológicos do estado. Tradução de Joaquim José de Moura Ramos. Lisboa: Presença, 1980.

Vozes, 2008.

Sobre a reprodução. Tradução de Guilherme João de Freitas Teixeira. Petrópolis:

AMANTEA, Alejandra et. al. Propostas curriculares na Argentina: as tradições disciplinar, da didática geral e das didáticas especiais. In: LOPES, Alice Casimiro; MACEDO, Elizabeth (Orgs.). Políticas de Currículo em Múltiplos Contextos. São Paulo: Cortez, 2006. p. 38-69. (Série cultura, memória e currículo; v. 7).

ANDERSON, Perry. Balanço do neoliberalismo. In: SADER, Emir; GENTILI, Pablo (Orgs.) Pós-neoliberalismo: as políticas sociais e o Estado democrático. Rio de Janeiro: Paz e Terra, 1995. p. 9-23.

As origens da pós-modernidade. Tradução de Marcus Penchel. Rio de Janeiro: Jorge Zahar Editor, 1999.

ANDRIOLI, Antonio Inácio. O governo Lula: continuidade da política neoliberal no Brasil? Revista Espaço Acadêmico, ano 6, n. 62, jul. 2006. Disponível em: <http://www.espacoaca demico.com.br/062/62andrioli.htm>. Acesso em: 08 ago. 2011.

ANTUNES, Ricardo; BRAGA, Ruy (Orgs.). Infoproletários: degradação real do trabalho virtual. São Paulo: Boitempo, 2009.

APPLE, Michael. Ideologia e currículo. Tradução de Carlos Eduardo Ferreira de Carvalho. São Paulo: Brasiliense, 1982.

ARAÚJO, Carlos Alberto Ávila. A ciência da informação como ciência social. Ci. Inf., Brasília, v. 32, n. 3, p. 21-27, set./dez. 2003. Disponível em:

<http://revista.ibict.br/index.php/ciinf/article/ view/29/26>. Acesso em: 27 abr. 2010.

ARAÚJO, Paulo Henrique Furtado de. Comentários sobre algumas teorias de ondas longas. Rev. Univ. Rural, Rio de Janeiro, v. 23, n. 2, p. 169-182, jul./dez. 2001.

ARENDT, Hannah. Entre o passado e o futuro. Tradução de Mauro W. Barbosa. 6. ed. São Paulo: Perspectiva, 2009.

AUGÉ, Marc. Não-lugares: introdução a uma antropologia da supermodernidade. Campinas: Papirus, 1994.

BARBROOK, Richard. Futuros imaginários: das máquinas pensantes à aldeia global. Tradução de Adriana Veloso et. al. São Paulo: Peirópolis, 2009. 
BARDIN, Laurence. Análise de conteúdo. Tradução de Luís Antero Reto e Augusto Pinheiro. 1. reimp. 1 ed. São Paulo: Edições 70, 2011.

BARRETO, Aldo de Albuquerque. A questão da informação. São Paulo em Perspectiva, São Paulo, v. 8, n. 4, 1994. Disponível em: 〈www.e-iasi.org/cinfor/quest/quest.htm〉. Acesso em: 28 maio 2010.

Mudança estrutural no fluxo do conhecimento: a comunicação eletrônica. Ciência da Informação, Brasília, v. 27, n. 2, p.122-127, 1998. Disponível em: <www.scielo.br/pdf/ci/ v27n2/barreto.pdf>. Acesso em: 28 maio 2010.

BAUER, Martin W.; GASKEL, George (Ed.). Pesquisa qualitativa com texto, imagem e som: um manual prático. Petrópolis: Vozes, 2002.

BAUMAN, Zygmunt. Amor líquido: sobre a fragilidade dos laços humanos. Tradução de Carlos Alberto Medeiros. Rio de Janeiro: Jorge Zahar Editor, 2004.

O mal-estar da pós-modernidade. Tradução de Mauro Gama e Cláudia Martinelli Gama. Rio de Janeiro: Jorge Zahar Editor, 1998.

Modernidade e ambivalência. Tradução de Marcus Penchel. Rio de Janeiro: Jorge Zahar Editor, 1999. Editor, 2001.

Modernidade líquida. Tradução de Plínio Dentzien. Rio de Janeiro: Jorge Zahar

Vidas desperdiçadas. Tradução de Carlos Alberto Medeiros. Rio de Janeiro: Jorge Zahar Editor, 2005.

BEHRENS, Marilda Aparecida. O paradigma emergente e a prática pedagógica. 5. ed. Petrópolis: Vozes, 2011.

BELL, Daniel. O advento da sociedade pós-industrial: tentativa de previsão social. Tradução de Heloysa de Lima Dantas. São Paulo: Cultrix, 1977.

BENJAMIN, Walter. A obra de arte na era de sua reprodutibilidade técnica. Primeira versão. In: ___ Magia e técnica, arte e política: ensaios sobre literatura e história da cultura. Tradução de Sergio Paulo Rouanet. 7. ed. São Paulo: Brasiliense, 1991. p. 165-196. (Obras escolhidas; v. 1).

Charles Baudelaire: um Lírico no Auge do Capitalismo. São Paulo: Brasiliense, 1991. (Obras escolhidas; v. 3).

BENTES PINTO, Virginia. Interdisciplinaridade na Ciência da Informação: aplicabilidade sobre a representação indexal. In: BENTES PINTO, Virginia; CAVALCANTE, Lídia Eugênia; SILVA NETO, Casemiro. Ciência da Informação: abordagens transdisciplinares, gêneses e aplicações. Fortaleza: UFC, 2007. p. 105-142. 
BOITO JÚNIOR, Armando. A hegemonia neoliberal no governo Lula. Crítica Marxista, Campinas, n. 17, 2003. Disponível em: <www.unicamp.br/cemarx/criticamarxista/critica17A-boito.pdf >. Acesso: 08 ago. 2011.

O governo Lula e a reforma do neoliberalismo. Revista ADUSP, São Paulo, p. 6-11, maio 2005. Disponível em: <http://www.adusp.org.br/revista/34/r34a01.pdf>. Acesso em: 08 ago. 2011.

BORKO, Harold. Information science: what is it? American Documentation, [s.1.], v. 19, n. 1, p. 3-5, jan. 1968.

BOURDIEU, Pierre. Escritos de educação. Seleção, organização, introdução e notas de Maria Alice Nogueira e Afrânio Catani. 7. ed. Petrópolis: Vozes, 2005.

BOURDIEU, Pierre; PASSERON, Jean-Claude. A reprodução: elementos para uma teoria do sistema de ensino. 3. ed. Petrópolis: Vozes, 2010.

BRASIL. Lei $n^{\circ}$ 5.540, de 28 de novembro de 1968. Fixa as normas de organização e funcionamento do ensino superior e sua articulação com a escola média, e dá outras providências. Diário Oficial [da] República Federativa do Brasil, Poder Executivo, Brasília, DF, 3 dez., 1968. Disponível em: <www.planalto.gov.br/ccivil_03/Leis/L5540.htm>. Acesso em: 18 mar. 2011.

. Lei $\mathrm{n}^{\circ}$ 9.131, de 24 de novembro de 1995. Altera dispositivos da Lei ${ }^{\circ} 4.024$, de 20 de dezembro de 1961, e dá outras providências. Diário Oficial [da] República Federativa do Brasil, Poder Executivo, Brasília, DF, 25 nov., 1995. Edição extra, 19257. Disponível em: <www.planalto.gov.br/ccivil_03/Leis/L9131.htm>. Acesso em: 18 mar. 2011.

Ministério da Educação. Lei n ${ }^{\circ}$ 9.334, de 20 de dezembro de 1996. Estabelece as diretrizes e bases da educação nacional. Diário Oficial [da] República Federativa do Brasil, Poder Executivo, Brasília, DF, 23 dez., 1996. Disponível em: <http://portal.mec.gov.br/seesp/ arquivos/pdf/lei9394_ldbn1.pdf>. Acesso em: 18 mar. 2011.

Parecer n. ${ }^{\circ}$ : CNE/CES 492/2001, de 3 abr. 2001. Diretrizes Curriculares Nacionais dos Cursos de: Filosofia, História, Geografia, Serviço Social, Comunicação Social, Ciências Sociais, Letras, Biblioteconomia, Arquivologia e Museologia. Diário Oficial [da] República Federativa do Brasil, Brasília, DF, 9 jul. 2001. Disponível em: <http://portal.mec.gov.br/cne/arquivos/pdf/CES0492.pdf>. Acesso em: 15 jul. 2009.

BUCKLAND, Michael K. Information as thing. Journal of the American Society for Information Science (JASIS), Maryland, v. 45, n. 5, p. 351-360, 1991.

BURKE, Peter. Uma história social do conhecimento: de Gutenberg a Diderot. Rio de Janeiro: Jorge Zahar, 2003.

BUSH, Vannevar. As we may think. Atlantic Monthly, Boston, v. 176, n. 1, p. 101-108, 1945. Disponível em: <http://www.ps.uni-saarland.de/ duchier/pub/vbush/vbush.shtml>. Acesso em: 29 abr. 2010. 
CAMBI, Franco. História da pedagogia. Tradução de Álvaro Lorencini. São Paulo: UNESP, 1999.

CAMPOS, Claudinei José Gomes. Método de análise de conteúdo: ferramenta para a análise de dados qualitativos no campo da saúde. Rev. Bras. Enferm., Brasília, v. 57, n. 5, p. 611614, set./out. 2004. Disponível em: < http://www.scielo.br/pdf/reben/v57n5/a19v57n5.pdf>. Acesso em: 20 jun. 2009.

CAPRA, Fritjof. Ponto de mutação: a ciência, a sociedade e a cultura emergentes. Tradução de Álvaro Cabral. 22. ed. São Paulo: Cultrix, 2001.

CAPURRO, Rafael. Epistemologia e Ciência da Informação. 2003. Disponível em: <http://www.capurro.de/enancib_p.htm>. Acesso em: 7 jun. 2010.

CAPURRO, Rafael; HJØRLAND, Birger. O Conceito de informação. Perspectivas em Ciência da Informação, Belo Horizonte, v. 12, n. 1, p. 148-207, jan./abr. 2007.

CARCANHOLO, Marcelo Dias; BARUCO, Grasiela Cristina da Cunha. A atual ideologia conservadora e o capitalismo contemporâneo: uma crítica à teoria pós-moderna neoliberal. 2008. Disponível em: <http://www.anpec.org.br/encontro2008/artigos/ 200807091134410.pdf>. Acesso em: 10 maio 2010.

CARDOSO, Ana Maria Pereira. Pós-modernismo e informação: conceitos complementares? Perspectivas em Ciência da Informação, Belo Horizonte, v. 1, n. 1, p. 63-79, jan./jul. 1996.

CASTELLS, Manuel. A sociedade em rede. 3. ed. São Paulo: Paz e Terra, 1999. 13. ed. São Paulo: Paz e Terra, 2010. (A era da informação: economia, sociedade e cultura, v. 1).

Internet e sociedade em rede. In: MORAES, Dênis de (Org.). Por uma outra comunicação: mídia, mundialização cultural e poder. Rio de Janeiro: Record, 2003. cap. 11, p. 255-287.

CASTRO, César Augusto de. História da biblioteconomia brasileira. Brasília: Thesaurus, 2000.

CAUNE, Jean. La médiation culturelle: une construction du lien social. 2000. Disponível em: < http://w3.u-grenoble3.fr/les_enjeux/2000/Caune/Caune.pdf>. Acesso em: 20 out. 2010.

CHAUÍ, Marilena; MATOS, Olgária. A contração do tempo e o espaço do espetáculo. 2010. Disponível em: <http://www.cpflcultura.com.br/site/2010/09/03/cafe-filosofico-cpflespecial-\%E2\%80\%93-a-contracao-do-tempo-e-o-espaco-do-espetaculo-\%E2\%80\%93marilena-chaui-e-olgaria-matos/>. Acesso em: 28 de nov. 2011.

COSTA, Maria de Fátima Oliveira; ANDRADE, Ivone Bastos Bonfim. Reflexões curriculares do ensino de Biblioteconomia no Ceará. Informação e Sociedade: estudos, João Pessoa, v. 9, n. 2, p. 406-412, 1999. 
COSTA, Maria de Fátima Oliveira; CARVALHO, Ana Maria Sá de; ANDRADE, Ivone Bastos Bonfim. Análise crítica do ensino de Biblioteconomia no Ceará: comentários preliminares. Fortaleza, [1995?]. Datilografado.

CUNHA, Miriam Vieira; SOUZA, Francisco das Chagas (Orgs.). Comunicação, gestão e profissão: abordagens para o estudo da Ciência da Informação. Belo Horizonte: Autêntica, 2006.

CYSNE, Fátima Portela. Biblioteconomia: dimensão social e educativa. Fortaleza: EUFC, 1993.

DAVALLON, Jean. A mediação: a comunicação em processo? Prisma.com, Porto, n. 4, p. 336, jun. 2007. Disponível em:

<http://prisma.cetac.up.pt/edicao_n4_junho_de_2007/a_mediacao_a_comunicacao_em_pr.ht ml>. Acesso em: 27 out. 2010.

DEBORD, Guy. A Sociedade do espetáculo. Tradução de Estela dos Santos Abreu. Rio de Janeiro: Contraponto, 1997.

DELEUZE, Gilles. Conversações. Rio de Janeiro: Editora 34, 1996.

DESCARTES, René. Discurso do método. Tradução de Paulo Neves. Porto Alegre: L\&PM, 1995. 123p.

DI MÉO, Guy. L'identité: une médiation essentielle du rapport espace/société. Géocarrefour, v. 77, n. 2, p. 175-184, 2002. Disponível em: <http://www.persee.fr/web/revues/home/ prescript/article/geoca_1627-4873_2002_num_77_2_1569>. Acesso em: 20 maio 2010.

DURKHEIM, Émile. As regras do método sociológico. Tradução de Maria I. P. de Queiroz. 13. ed. São Paulo: Companhia Editora Nacional, 1987.

EAGLETON, Terry. As ilusões do pós-modernismo. Tradução de Elisabeth Barbosa. Rio de Janeiro: Zahar, 1998.

FEATHERSTONE, Mike. Cultura de consumo e pós-modernismo. Tradução de Julio Assis simões. São Paulo: Studio Nobel, 1995. (Coleção Cidade Aberta. Série Megalópole).

FLORIS, Bernard. Les médiations dans les rapports sociaux. Réseaux, Cachan, v. 13, n. 69, p. 141-156, 1995. Disponível em:

<http://www.persee.fr/web/revues/home/prescript/article/reso_07 51-

971_1995_num_13_69_2643>. Acesso em: 15 jun. 2010.

FOUCAULT, Michel. A arqueologia do saber. Tradução de Felipe Baeta neves. 7. ed. 3. reimp. Rio de janeiro: Forense Universitária, 2008. paginado.

Vigiar e punir: história da violência nas prisões. Petrópolis: Vozes, 1999. Não 
FOURIE, Ina. ¿Debemos tomarnos en serio la desintermediación? Anales de

Documentación, Espinardo, n. 4, p. 267-282, 2001. Disponível em: <http://redalyc.uaemex. mx/src/inicio/ ArtPdfRed. jsp?i Cve=63500415>. Acesso em: 04 nov. 2011.

FREIRE, Paulo. Ação Cultural para a liberdade e outros escritos. 5. ed. Rio de Janeiro: Paz e Terra, 1981.

Cartas à Guiné-Bissau: registros de uma experiência em processo. 2. ed. Rio de Janeiro: Paz e Terra, 1978.

Conscientização: teoria e prática da libertação; uma introdução ao pensamento de Paulo Freire. São Paulo: Cortez e Moraes, 1979. Não paginado.

Educação como prática da liberdade. Rio de Janeiro: Paz e Terra, 1967.

Educação e atualidade brasileira. 1959. 139f. Tese (Concurso público para a cadeira de História e Filosofia da Educação da Escola de Belas Artes de Pernambuco)Universidade Federal do Recife, Recife, 1959.

Extensão ou Comunicação? Tradução de Rosisca Darcy de Oliveira. Rio de Janeiro: Paz e Terra, 1983. Não paginado.

Paulo Freire: entrevista [parte 2]. Entrevistadora: Antonia Terra de Calazans Fernandes. São Paulo: Secretaria de Estado da Cultura de São Paulo, 1997. Entrevista concedida ao Projeto Memória Oral do Idoso do Museu da Pessoa. Disponível em: <http://www.youtube.com/watch?v =fBXFV4Jx6Y8>. Acesso em: 20 set. 2010.

Pedagogia da autonomia: saberes necessários à prática educativa. Rio de Janeiro: Paz e Terra, 1997.

Pedagogia da indignação: cartas pedagógicas e outros escritos. Prefácio de Balduíno A. Andreola. Apresentação de Ana Maria Araújo Freire. São Paulo: Editora Unesp, 2000.

Pedagogia do oprimido. 17 . ed. Rio de Janeiro: Paz e terra, 2005.

FREITAS, Lima de; MORIN, Edgar; NICOLESCU, Basarab. Carta da Transdisciplinaridade. In: CONGRESSO MUNDIAL DA TRANSDISCIPLINARIDADE, 1., 1994, Portugal. Anais..., Azeitão, 1994. Disponível em: <http://www.ufrrj.br/leptrans/arquivos/Arquivo_14_Carta_Transdisciplinaridade_I_CONGRE SMUNDIAL.pdf>. Acesso em: 20 jun. 2011.

FROHMANN, Bernd. O caráter social, material e público da informação. In: ENCONTRO NACIONAL DE PESQUISA EM CIÊNCIA DA INFROMAÇÃO, 7., 19 a 22 nov. 2006, Marília. Anais... Marília: ANCIB; UNESP, 2006. (Publicação em CD-ROM).

FUJINO, Asa; LIMA, Vânia Mara Alves de. Pesquisar o ensinar: uma proposta de avaliação da ação didático-pedagógica em Biblioteconomia e Documentação da Universidade de São Paulo. In: ENCONTRO NACIONAL DE PESQUISA EM CIÊNCIA DA INFORMAÇÃO, 
9., 2008, São Paulo. Anais eletrônicos... São Paulo, 2008. Diversidade Cultural e Políticas de Informação, 2008. v. 1.

FUJINO, Asa; VASCONCELOS, Michele de Oliveira. Estágios: reflexões sobre a ação didático-pedagógica na formação do profissional da informação. CRB-8 Digital, São Paulo, v. 4, n. 1, p. 40-58, abr. 2011. Disponível em: 〈http://revista.crb8.org.br〉. Acesso em: 20 dez. 2011.

GARCÍA CANCLINI, Néstor. Culturas híbridas: estratégias para entrar e sair da modernidade. Tradução de Heloísa P. Cintrão e Ana R. Lessa. São Paulo: EDUSP, 1997.

Diferentes, desiguais e desconectados: mapas da interculturalidade. Tradução de Luiz Sérgio Henriques. 2. ed. Rio de Janeiro: Editora UFRJ, 2007.

GAY, Peter. Modernismo: o fascínio da heresia: de Baudelaire a Beckett e mais um pouco. Tradução de Denise Bottman. São Paulo: Companhia das Letras, 2009.

GENTILI, Pablo. Neoliberalismo e educação: manual do usuário. In: SILVA, Tomaz Tadeu da; GENTILI, Pablo (Org.). Escola S.A. São Paulo: CEFET/SP, 1996.

GENTILI, Pablo A. A.; SILVA, Tomaz Tadeu da (Orgs.). Neoliberalismo, qualidade total e educação: visões críticas. 8. ed. Petrópolis: Vozes, 1999.

GHIRALDELLI JÚNIOR, Paulo (Org.). Infância, educação e neoliberalismo. 2. ed. São Paulo: Cortez, 2000.

GIDDENS, Anthony. As consequências da modernidade. Tradução de Raul Fiker. São Paulo: UNESP, 1991.

Mundo em descontrole: o que a globalização está fazendo de nós. Tradução de Maria Luiza Borges. Rio de Janeiro: Record, 2000.

GIL, Antonio Carlos. Métodos e técnicas de pesquisa social. São Paulo: Atlas, 1999.

GOHN, Maria da Glória. Paulo Freire e a formação de sujeitos sociopolíticos. Cadernos de Pesquisa: pensamento educacional, Paraná, v. 4, n. 8, jul./dez. 2009. Disponível em: < http://www.utp.br/Cadernos_de_Pesquisa/pdfs/cad_pesq8/2_paulo_freire_cp8.pdf $>$. Acesso em: 20 nov. 2011.

GONZALEZ DE GÓMEZ, Maria Nélida; ORRICO, Evelyn G. D. Interdisciplinaridade: questões norteadoras e possíveis caminhos. In: GONZALEZ DE GÓMEZ, Maria Nélida; ORRICO, Evelyn G. D. (Orgs.) Políticas de Memória e Informação: questões norteadoras e possíveis caminhos. Natal: Ed. da EDUFRN, 2006, p. 9-27.

GUINZBURG, Carlo. Réprésentation: le mot, l'idée, la chose. Analles, [s.1.], n. 16, p. 12191234, nov./déc. 1991.

HALL, Stuart. A identidade cultural na pós-modernidade. Tradução de Tomaz Tadeu da Silva e Guacira Lopes Laura. 7. ed. Rio de Janeiro: DP\&A, 2002. 
HARVEY, David. Condição pós-moderna. 8. ed. Tradução de Adail Ubirajara Sobral; Maria Stela Gonçalves. São Paulo: Loyola, 2000. (Temas de Atualidade, v. 1).

Tradução de Adail Ubirajara Sobral; Maria Stela Gonçalves. 11. ed. São

Paulo: Loyola, 2003. (Temas de Atualidade, v. 1).

O neoliberalismo: história e implicações. Tradução de Adail Sobral e Maria Stela Gonçalves. São Paulo: Loyola, 2008.

HEGEL, G. W. F. Fenomenologia do espírito. 2. ed. Tradução de Paulo Menezes. Petrópolis: Vozes, 1992.

HOLANDA, Francisco Uribam Xavier de. Do liberalismo ao neoliberalismo: o itinerário de uma cosmovisão impenitente. 2. ed. Porto Alegre: EDIPUCRS, 2001.

HOBBES, Thomas. Leviatã, ou matéria, forma e poder de um estado eclesiástico e civil. Tradução de Alex Marins. São Paulo: Martin Claret, 2002.

JAMESON, Fredric. Pós-modernismo: a lógica cultural do capitalismo tardio. 2. ed. Tradução de Maria Elias Cevasco. São Paulo: Ática, 2007.

JANNUZZI, Paulo; MATTOS, Fernando. Duas décadas de conjuntura econômica.

Transinformação, Campinas, v. 13, n. 2, p. 111-129, jul./dez. 2001.

JOUËT, Josiane. Pratiques de communication et figures de la médiation: des médias de masse aux technologies de l'information et de la communication. Sociologie de la communication, Paris, v. 1, n. 1, p. 291-312, 1997. Disponível em: <http://www.persee.fr/web/revues/home/ prescript/article/reso_004357302_1997_mon_1_1_3843>. Acesso em: 15 nov. 2010.

Pratiques de communication et figures de la médiation. Réseaux, Paris, v. 11, n. 60, p. 99-120, 1993. Disponível em:

<http://www.persee.fr/web/revues/home/prescript/article/reso_07 51-

7971_1993_num_11_60_2369>. Acesso em: 15 nov. 2010.

KUHN, Thomas. A estrutura das revoluções científicas. 7. ed. São Paulo: Perspectiva, 2003. 262p.

LAMIZET, Bernard. Culture: commonness of the common? Trans: Internet-Zeitschrift für Kulturwissenschaften, Áustria, n. 15, Jun. 2004. Disponível em: <http://www.inst.at/trans /15Nr/01_2/lamizet15.htm>. Acesso em: 23 mar. 2011.

LAMIZET, Bernard; SILEM, Ahmed. Dictionnaire encyclopédique des sciences de l'information et de la communication. Paris: Ellipses, 1967.

LATOUR, Bruno. Jamais fomos modernos: ensaio de antropologia simétrica. Tradução de Carlos Irineu da Costa. 2. ed. Rio de Janeiro: Ed. 34, 2009.

Redes que a razão desconhece: laboratórios, bibliotecas, coleções. In: BARATIN, Marc; JACOB, Christian. O poder das bibliotecas: a memória dos livros no Ocidente. Tradução de Marcela Mortara. Rio de Janeiro: UFRJ, 2000. p. 21-44. 
LAVAL, Christian. A escola não é uma empresa: o neo-liberalismo em ataque ao ensino público. Tradução de Maria Luiza M. de Carvalho e Silva. Londrina: Planta, 2004.

LAVILLE, Christian; DIONNE, Jean. A construção do saber: manual de metodologia da pesquisa em ciências humanas. Belo Horizonte: Editora UFMG; Porto Alegre: Artmed, 1999.

LE COADIC, Yves-François. A Ciência da Informação. Tradução de Maria Yeda F. S. de Figueiredo Gomes. Brasília: Briquet de Lemos, 1996.

Brasília: Briquet de Lemos, 2007.

LIBÂNEO, José Carlos. Sistema de ensino, escola, sala de aula: onde se produz a qualidade das aprendizagens? In: LOPES, Alice Casimiro; MACEDO, Elizabeth (Orgs.). Políticas de Currículo em múltiplos contextos. São Paulo: Cortez, 2006. p. 70-125. (Série cultura, memória e currículo; v. 7).

LIBERA, Alain de. Pensar na Idade Média. Tradução de Paulo Neves. São Paulo: Ed. 34, 1999. (Coleção TRANS).

LYOTARD, Jean-François. La condition postmoderne: rapport sur le savoir. Paris: Éditions de Minuit, 1979.

MARRACH, Sonia Alem. Neoliberalismo e educação. In: SILVA JÚNIOR, Celestino A. da. et. al. Infância, educação e neoliberalismo. São Paulo: Cortez, 2001. p. 42-56.

MARTINS, José de Souza. A sociabilidade do homem simples: cotidiano e história na sociedade anômala. 3. ed. São Paulo: Contexto, 2011.

MARX, Karl; ENGELS, Friedrich. Manifesto do Partido Comunista. São Paulo: Martin Claret, 2003.

MARX, Karl. O Capital; Crítica da Economia Política; O processo de Produção do Capital. Tradução de Régis Barbosa e Flávio R. Kothe. São Paulo: Nova Cultural, 1996.

Manuscritos econômico-filosóficos. São Paulo: Boitempo, 2004. (Os três manuscritos econômicos de 1857-1858 compõem os Grundrisse).

MASUDA, Yoneji. Sociedade da Informação como sociedade pós-industrial. Rio de Janeiro: Ed Rio, 1982.

MATOS, Olgária Chain Féres. O crepúsculo dos sábios. O Estado de São Paulo, São Paulo, 15 nov. 2009. Caderno Aliás.

Benjaminianas: cultura capitalista e fetichismo contemporâneo. São Paulo: Editora UNESP, 2010. 341p.

MATTELART, Armand. História da Sociedade da Informação. Tradução de Nicolas Nyimi Campanário. São Paulo: Loyola, 2006. 
MIÈGE, Bernard. A sociedade tecida pela comunicação: técnicas da informação e da comunicação entre inovação e enraizamento social. Tradução de Florence Trazet. São Paulo: Paulus, 2009. (Coleção Comunicação).

MILANESI, Luis. A formação do informador. Infor. Inform., Londrina, v. 7, n. 1, jan./jun. 2002. Disponível em: <www.uel.br/revistas/uel/index.php/informacao/article/view/1694>. Acesso em: 20 jun. 2011.

MILANO, M. C. D.; DAVOK, D. F. Consultor de informação: serviços prestados por empresas de consultorias nas áreas de Biblioteconomia e Gestão da Informação. Revista ACB: Biblioteconomia em Santa Catarina, Florianópolis, v. 14, n. 1, p. 253-278, jan./jun., 2009.

MONTOYA, Nathalie. Médiation et médiateurs culturels: quelques prolèmes de definition dnas la construction d'une activité professionnelle. Liens social et politiques, Canadá, n. 60, p. 25-35, 2008. Disponível em: <http://id.erudit.org/iderudit/019443ar〉. Acesso em: 07 dez. 2010 .

MORAES, Marielle Barros de. A formação do bibliotecário na UFC à luz do neoliberalismo: ser ou não ser! 2007.105f. Monografia (Graduação em Biblioteconomia)Universidade Federal do Ceará, Fortaleza, 2007.

MOREIRA, Antonio Flávio; SILVA, Tomaz Tadeu da (Orgs.). Currículo, cultura e sociedade. Tradução de Maria Aparecida Baptista. 3. ed. São Paulo: Cortez, 1999.

MORIGI, Valdir José; SEMENSATTO, Simone; BINOTTO, Sibila Francine Tengaten. Ciclo e fluxo informacional nas festas comunitárias. Informação e sociedade: estudos, João Pessoa, v. 16, n. 1, p. 193-201, jan./jun. 2006.

MOSTAFA, Solange Puntel. A pós-graduação busca o fogo do conhecimento. Transiformação, Campinas, v.1, n. 1, p. 13-23, jan./abr. 1989.

MOZZINI, Camila Pós-modernidade, digitalização e o exemplo da TV digital no Brasil. BOCC: Biblioteca On-line de Ciências da Comunicação, Porto, v. 01, p. 1-6, 2010. Disponível em: <http://www.bocc.ubi.pt/pag/mozzini-camila-pos-modernidadedigitalizacao.pdf $>$. Acesso em: 30 abr. 2011.

MUELLER, Suzana Pinheiro Machado. Será a Ciência da informação brasileira realmente transdisciplinar? Um retrato instantâneo de suas fontes e assuntos. In: BENTES PINTO, Virginia; CAVALCANTE, Lídia Eugênia; SILVA NETO, Casemiro. Ciência da Informação: abordagens transdisciplinares, gêneses e aplicações. Fortaleza: UFC, 2007. p. 143-164.

MUSSO, Pierre. A filosofia da rede. In: PARENTE, André (Org.). Tramas da rede. Porto Alegre: Sulina, 2004. p. 17-37.

OLIVEIRA, Eliana de et al. Análise de conteúdo e pesquisa na área da educação. Metodologia, política e filosofia da educação, São Paulo,v. 4, n. 9, p. 11-27, maio/ago. 2003. Disponível em: 
<http://www2.pucpr.br/reol/index.php/DIALOGO?dd1=637\&dd99=view>. Acesso em: 15 fev. 2007.

OLIVEIRA, Maria Auxiliadora Monteiro. Escola ou empresa? Petrópolis: Vozes, 1998.

ORTEGA, Cristina Dotta. Relações históricas entre Biblioteconomia, Documentação e Ciência da Informação. Datagramazero: revista de Ciência da Informação, [s.1], v. 5, n. 5, out. 2004.

Surgimento e consolidação da Documentação: subsídios para a compreensão da história da Ciência da Informação no Brasil. Perspectiva em Ciência da Informação, Belo Horizonte, v. 14, n. esp., p. 59-79, 2009.

PIERUCCINI, I. A ordem informacional dialógica: estudo sobre a busca de informação em educação. 2004. 194f. Tese (Doutorado em Ciência da Informação e Documentação)- Escola de Comunicações e Artes, Universidade de São Paulo, São Paulo, 2004.

Ordem informacional dialógica: mediação como apropriação da informação. In: ENCONTRO NACIONAL DE PESQUISA EM CIÊNCIA DA INFORMAÇÃO, 8., 2007, Salvador. Anais eletrônicos... Salvador, 2007. Disponível em: <www.enancib.ppgci.ufba.br/artigos/GT3--159.pdf>. Acesso em: 25 nov. 2010.

PINHEIRO, Lena Vânia Ribeiro. Processo evolutivo e tendências contemporâneas da Ciência da Informação. Informação e Sociedade, João Pessoa, v. 15, n. 1, p. 13-48, jan./jun. 2005.

POBLACIÓN, D. A. Pesquisa e pós-graduação em Ciência da Informação e Biblioteconomia no Brasil: duas fases (1970/85-1992). In: ENCONTRO NACIONAL DE PÓSGRADUAÇÃO EM CIÊNCIA DA INFORMAÇÃO E BIBLIOTECONOMIA, 12., São Paulo, 1992. Anais... São Paulo, 1992, p. 7-14.

POLKINGHORNE, John. Teoria quântica.Tradução de Iuri Abreu. Porto Alegre: L\&PM, 2011.

RAMOS, Fernanda Peres; NEVES, Marcos Cesar Danhoni; CORAZZA, Maria Júlia. Os paradigmas da ciência moderna e pós-modernas e as concepções de professores pesquisadores. 2009. Disponível em: < www.foco.fae.ufmg.br/cd/pdfs/629.pdf>. Acesso em: 20 maio 2010.

RASSE, Paul. La mediation, entre ideal theorique et application pratique. Recherche en communication, Louvain, n. 13, p. 38-61, 2000. Disponível em:<sitestest.uclouvain.be/rec/index.php/ rec/article/view/2711/2511>. Acesso em: 17 ago 2010.

RAYWARD, W. Boyd. The origins of Information Science and the International Institute of Bibliography/International Federation for Information and Documentation (FID). Journal of the American Society for Information Science, Maryland, v. 48, n. 4, p. 289-300, 1997.

REALE, Giovanni. História da Filosofia Antiga: das origens a Sócrates. Tradução de Marcelo Perene. São Paulo: Loyola, 1993. V. 1. 
RÍOS ORTEGA, Jaime. Didáctica de la Bibliotecología: teoría y principios desde la enseñanza de la ciencia. México: UNAM, 2008. 118p.

ROCHA, Décio; DEUSDARÁ, Bruno. Análise de Conteúdo e Análise de Discurso: aproximações e afastamentos na (re)construção de uma trajetória. Alea, [s.1], v. 7, n. 2, p. 305-322, jul./dez., 2005.

RODRIGUES, Adriano Duarte. Dicionário breve da informação e da comunicação. Lisboa: Presença, 2000.

ROUSSEAU, Jean-Jacques. Emílio ou da Educação. Tradução de Roberto Leal Ferreira. 2. ed. São Paulo: Martins Fontes, 1999.

RUSSO, L. G. M. A Biblioteconomia Brasileira: 1915/1965. Rio de Janeiro: Instituto Nacional do Livro, 1966.

SANTAELLA, Lucia; LEMOS, Renata. Redes sociais digitais: a cognição conectiva do Twitter. São Paulo: Paulus, 2010. (Coleção Comunicação).

SARACEVIC, Tefko. A natureza interdisciplinar da Ciência da Informação. Ciência da Informação, Brasília, v. 24, n. 1, 1996.

SARTRE, Jean-Paul. O existencialismo é um humanismo; A imaginação; Questão de método. Seleção de textos de José Américo Motta Pessanha. Tradução de Vergílio Ferreira; Luiz Roberto Salinas Fortes; Bento Prado Júnior. São Paulo: Abril Cultural, 1978. (Os pensadores).

SCHNEIDER, Sérgio; SCHMITT, J. Cláudia. O uso do método comparativo nas ciências sociais. Cadernos de Sociologia, Porto Alegre, v. 9, p. 49-87, 1998.

SELLA, Adriano. Globalização neoliberal e exclusão social: alternativas...? São Possíveis! São Paulo: Paulus, 2002.

SILVA, Tomaz Tadeu da. Documentos de identidade: uma introdução às teorias do currículo.2. ed. 11. reimp. Belo Horizonte: Autêntica, 2007.

SILVA, Edna Lúcia da; CUNHA, Miriam Vieira da. A formação profissional no século XXI: desafios e dilemas. Ci. Inf., Brasília, v. 31, n. 3, p. 77-82, set./dez.2002.

SILVA, Edna Lúcia da; LOPES, Marili Isensee. A internet, a mediação e a desintermediação da informação. Datagramazero, Rio de Janeiro, v. 12, n. 2, abr. 2011. Disponível em: <http://www.dgz.org.br/abr11/Art_04.htm>. Acesso em: 03 nov. 2011.

SMIT, J. W. O profissional da informação e sua relação com as áreas de Biblioteconomia/Documentação, Arquivologia e Museologia. In: VALENTIM, M. L. P. (Org.). Profissionais da informação: formação, perfil e atuação profissional. São Paulo: Polis, 2000. cap. 6, p. 119-134.

SMIT, J. W.; TÁLAMO, M. F. G. M.; KOBASHI, N. Y. A determinação do campo científico da Ciência da Informação: uma abordagem terminológica. Datagramazero, Rio de Janeiro, v. 
5, n. 1, fev. 2004. Disponível em: <http://www.dgz.org.br/fev04/F_I_art.htm>. Acesso em: 10 mar. 2011.

SOUSA, R. T. B. de. Os desafios da formação do arquivista no Brasil. In: CONGRESSO BRASILEIRO DE ARQUIVOLOGIA, 15., 2008, Goiânia. Anais eletrônico... Rio de Janeiro: AAB, 2008. Disponível em: <http://www.aag.org.br/anaisxvcba/conteudo/resumos/ plenaria2/renatotarciso.pdf > . Acesso em: 20 dez. 2011.

SOUSA SANTOS, B. Um discurso sobre as ciências. Porto: Afrontamento, 1987.

Introdução a uma ciência pós-moderna. Rio de Janeiro: Graal, 1989.

1986.

Pela mão de Alice: o social e o político na pós-modernidade. São Paulo: Cortez,

. O social e o político na transição pós-moderna. Lua Nova, São Paulo, n. 31, dez., 1993.

SOUZA, Francisco das Chagas de. Educação bibliotecária, pesquisa em educação bibliotecária e as novas DCN (Diretrizes Curriculares Nacionais) do Curso de Biblioteconomia do Brasil. Informação e Sociedade, João Pessoa, v. 12, n. 2, 2002. Disponível em: <http://www.ies.ufpb.br/ojs2/index.php/ies/article/view/149/143>. Acesso em: 10 maio 2011. $\overline{\text { UFSC, }} 1990$.

O Ensino da Biblioteconomia no Contexto Brasileiro. Florianópolis: Ed. da

O ensino de biblioteconomia no contexto brasileiro: século XX. Florianópolis: Ed. da UFSC, 2009. v. 1.

O discurso sobre a educação em Biblioteconomia e Ciência da Informação no Brasil: caminhos teóricos-metodológicos para a compreensão. In: CUNHA, Miriam Vieira; SOUZA, Francisco das Chagas (Orgs.). Comunicação, Gestão e Profissão: abordagens para o estudo da Ciência da Informação. Belo Horizonte: Autêntica, 2006. cap. 8. p. 151-172.

A Escola de Biblioteconomia e a ancoragem da profissão de bibliotecário.

Informação e Sociedade: Estudos, João Pessoa, v. 11, n. 2, p. 1-12, 2001. Disponível em: <http://www.ies.ufpb.br/ojs2/index.php/ies/issue/view/32/showToc >. Acesso em: 10 abr. 2011.

A formação acadêmica de bibliotecários e cientistas da informação e sua visibilidade, identidade e reconhecimento social no Brasil. Informação e Sociedade: Estudos, João Pessoa, v. 16, n. 1, p. 23-34, jan./jun., 2006. Disponível em: <http://www.ies.ufpb.br/ojs2/ index.php/ies/issue/view/32/showToc>. Acesso em: 10 abr. 2011.

Formação de bibliotecários para uma sociedade livre. Encontros Bibli: Ver.

Bibliotecon. Ci. Inf., Florianópolis, n. 11, jun., 2001. Disponível em:

<http://www.ced.ufsc.br/bibliote/encontro/>. Acesso em: 10 abr. 2011. 
Interdisciplinaridade da Ciência da Informação. In: BENTES PINTO, Virginia; CAVALCANTE, Lídia Eugênia; SILVA NETO, Casemiro. Ciência da Informação: abordagens transdisciplinares, gêneses e aplicações. Fortaleza: UFC, 2007. p. 49-70.

SOUZA, Sebastião de. Fundamentos Filosóficos da Biblioteconomia. Rev. Bibliotecon., Brasília, n. 14, v. 2, p. 189-196, jul./dez., 1986.

TÁLAMO, Maria de Fátima Gonçalves Moreira; SMIT, Johanna Wilhelmina Smit. Ciência da Informação: a transgressão metodológica. In: BENTES PINTO, Virginia; CAVALCANTE, Lídia Eugênia; SILVA NETO, Casemiro. Ciência da Informação: abordagens transdisciplinares, gêneses e aplicações. Fortaleza: UFC, 2007. p. 23-48.

THOMPSON, John B. A mídia e a modernidade: uma teoria social da mídia. 4. ed. Petrópolis: Vozes, 2002.

Ideologia e Cultura moderna: teoria social crítica na era dos meios de comunicação de massa. 4. ed. Petrópolis: Vozes, 2000.

TYLER, Ralph W. Princípios básicos de currículo e ensino. Tradução de Leonel Vallandro. 3. ed. Porto Alegre: Globo, 1976.

UNIVERSIDADE FEDERAL DO PARÁ. Escola de Biblioteconomia. Projeto Pedagógico do Curso de Biblioteconomia. Belém: [s.n.], 2009.

UNIVERSIDADE FEDERAL DE SANTA CATARINA. Curso de Biblioteconomia. Projeto Político-Pedagógico do Curso de Biblioteconomia da Universidade Federal de Santa Catarina. Florianópolis: [s.n.], 2008. Disponível em: <http://www.cin.ufsc.br/bibliotecono mia/docs.php>. Acesso em: 12 abr. 2011.

VALENTIM, Marta Lígia Pomim. Ambientes e fluxos de informação. In: São Paulo: Cultura Acadêmica, 2010. cap. 1. p. 13-22.

Formação do profissional da informação. São Paulo: Polis, 2002.

VATTIMO, Gianni. O fim da modernidade: niilismo e hermenêutica na cultura pósmoderna. Tradução de Eduardo Brandão. São Paulo: Martins Fontes, 1996.

VEILLETTE, J. Quand la culture fait médiation... Lien social et politiques, n. 60, p. 105115, 2008. Disponível em: <http://id.erudit.org/iderudit/019449ar>. Acesso em: 7 dez. 2010.

VIANA, Nildo. Modernidade e pós-modernidade. Enfrentamento, [s.1], ano 4, n. 6, p. 25-35, jan./jun. 2009.

WEBER, Max. A ética protestante e o espírito do capitalismo. São Paulo: Editora Martin Claret, 2006.

WERSIG, G. Information Science: the study of postmodern knowledge usage. Information Processing \& Management, [s.1], v. 29, n. 2, p. 229-239, 1993.

ZARADER, Jean-Pierre. Dictionnaire de philosophie. Paris: Ellipses, 2007. 